

\section{Migration, Civil Society and Global Governance}

How do the United Nations, international organizations, governments, corporate actors and a wide variety of civil society organizations and regional and global trade unions perceive the root causes of migration, global inequality and options for sustainable development? This is one of the most pertinent political questions of the 21 st century.

This comprehensive collection examines the development of an emerging global governance on migration with the focus on spaces, roles, strategies and alliance-making of a composite transnational civil society engaged in issues of rights and the protection of migrants and their families. It reveals the need to strengthen networking and convergence among movements that adopt different entry points to the same struggle, from fighting 'managed' migration to contesting corporate control of food and land. The authors examine the opportunities and challenges faced by civil society in its endeavour to promote a rights-based approach within international and intergovernmental fora engaged in setting up a global compact for the management of migration, such as the Global Forum for Migration and Development, and in other global policy spaces.

This book was originally published as a special issue of the journal Globalizations.

Carl-Ulrik Schierup is a Professor Emeritus at the Institute for Research on Migration, Ethnicity and Society (REMESO) at Linköping University, Sweden.

Branka Likić-Brborić is a Professor Designate at the Institute for Research on Migration, Ethnicity and Society (REMESO) at Linköping University, Sweden.

Raúl Delgado Wise is a Professor and the Director of the Doctoral Program in Development Studies at the Autonomous University of Zacatecas, Mexico.

Gülay Toksöz was a Professor in the Department of Labour Economics and Industrial Relations at Ankara University, Turkey, but retired in 2016 due to political conditions. 


\section{Rethinking Globalizations}

Edited by Barry K. Gills, University of Helsinki, Finland and Kevin Gray, University of Sussex, UK

This series is designed to break new ground in the literature on globalization and its academic and popular understanding. Rather than perpetuating or simply reacting to the economic understanding of globalization, this series seeks to capture the term and broaden its meaning to encompass a wide range of issues and disciplines and convey a sense of alternative possibilities for the future.

\section{Environmental Security in Transnational Contexts}

What Relevance for Regional Human Security Regimes?

Edited by Harlan Koff and Carmen Maganda

The Role of Religion in Struggles for Global Justice

Faith in Justice

Edited by Peter J. Smith, Katharina Glaab, Claudia Baumgart-Ochse and Elizabeth Smythe

Vivir Bien as an Alternative to Neoliberal Globalization

Can Indigenous Terminologies Decolonize the State?

Eija Ranta

Feminist Global Political Economies of the Everyday

Edited by Juanita Elias and Adrienne Roberts

The Politics of Destination in the 2030 Sustainable Development Goals

Leaving No-one Behind?

Edited by Clive Gabay and Suzan Ilcan

BRICS and MICs

Implications for Global Agrarian Transformation

Edited by Ben Cousins, Saturnino M. Borras Jr., Sergio Sauer and Jingzhong Ye

Migration, Civil Society and Global Governance

Edited by Carl-Ulrik Schierup, Branka Likić-Brborić, Raúl Delgado Wise and Gülay Toksöz

For more information about this series, please visit: https://www.routledge.com/RethinkingGlobalizations/book-series/RG 


\section{Migration, Civil Society and Global Governance}

\section{Edited by}

Carl-Ulrik Schierup, Branka Likić-Brborić, Raúl Delgado Wise and Gülay Toksöz 
First published 2019

by Routledge

2 Park Square, Milton Park, Abingdon, Oxon, OX14 4RN

and by Routledge

52 Vanderbilt Avenue, New York, NY 10017

Routledge is an imprint of the Taylor \& Francis Group, an informa business

Chapters 2, 4-5, 7-10 @ 2019 Taylor \& Francis

Chapter 1 (c) 2018 Carl-Ulrik Schierup, Branka Likić-Brborić, Raúl Delgado Wise and

Gülay Toksöz. Originally published as Open Access.

Chapter 3 (c) 2018 Branka Likić-Brborić. Originally published as Open Access.

Chapter 6 (C) 2018 Aleksandra Ålund and Carl-Ulrik Schierup. Originally published as

Open Access.

With the exception of Chapters 1, 3 and 6, no part of this book may be reprinted or reproduced or utilised in any form or by any electronic, mechanical, or other means, now known or hereafter invented, including photocopying and recording, or in any information storage or retrieval system, without permission in writing from the publishers. For details on the rights for Chapters 1, 3 and 6, please see the chapters' Open Access footnotes.

Chapters 1, 3 and 6 of this book are available for free in PDF format as Open Access from the individual product page at www.routledge.com. It has been made available under a Creative Commons Attribution-Non Commercial-No Derivatives 4.0 license.

Trademark notice: Product or corporate names may be trademarks or registered trademarks, and are used only for identification and explanation without intent to infringe.

British Library Cataloguing-in-Publication Data

A catalogue record for this book is available from the British Library

ISBN13: 978-0-367-14726-6

Typeset in Minion Pro

by codeMantra

\section{Publisher's Note}

The publisher accepts responsibility for any inconsistencies that may have arisen during the conversion of this book from journal articles to book chapters, namely the inclusion of journal terminology.

\section{Disclaimer}

Every effort has been made to contact copyright holders for their permission to reprint material in this book. The publishers would be grateful to hear from any copyright holder who is not here acknowledged and will undertake to rectify any errors or omissions in future editions of this book. 


\section{Contents}

Citation Information vii

Notes on Contributors $\quad$ ix

Editors' Note 1

Carl-Ulrik Schierup, Branka Likić-Brborić, Raúl Delgado Wise and Gülay Toksöz

1 Migration, civil society and global governance: an introduction to the special issue 3 Carl-Ulrik Schierup, Branka Likić-Brborić, Raúl Delgado Wise and Gülay Toksöz

2 Is there a space for counterhegemonic participation? Civil society in the global governance of migration

Raúl Delgado Wise

3 Global migration governance, civil society and the paradoxes of sustainability Branka Likić-Brborić

4 Irregular migration and migrants' informal employment: a discussion theme in international migration governance

Gülay Toksöz

5 Repoliticizing international migration narratives? Critical reflections on the Civil Society Days of the Global Forum on Migration and Development Kellynn Wee, Kudakwashe P. Vanyoro and Zaheera Jinnah

6 Making or unmaking a movement? Challenges for civic activism in the global governance of migration Aleksandra Ålund and Carl-Ulrik Schierup

7 The problem of representation: civil society organizations from Turkey in the GFMD process

Cavidan Soykan and Nazlı Şenses

8 Syrian refugees in Turkey and trade union responses 
9 Angry birds of passage - migrant rights networks and counter-hegemonic resistance to global migration discourses Stefan Rother

10 'Getting to the root causes of migration' in West Africa - whose history, framing and agency counts?

Nora McKeon

Postscript: The Global Compact for Migration: what road from Marrakech? 


\section{Citation Information}

The chapters in this book were originally published in the journal Globalizations, volume 15, issue 6 (October 2018). When citing this material, please use the original page numbering for each article, as follows:

\section{Chapter 1}

Migration, civil society and global governance: an introduction to the special issue Carl-Ulrik Schierup, Branka Likić-Brborić, Raúl Delgado Wise and Gülay Toksöz

Globalizations, volume 15, issue 6 (October 2018) pp. 733-745

\section{Chapter 2}

Is there a space for counterhegemonic participation? Civil society in the global governance of migration

Raúl Delgado Wise

Globalizations, volume 15, issue 6 (October 2018) pp. 746-761

\section{Chapter 3}

Global migration governance, civil society and the paradoxes of sustainability

Branka Likić-Brborić

Globalizations, volume 15, issue 6 (October 2018) pp. 762-778

\section{Chapter 4}

Irregular migration and migrants' informal employment: a discussion theme in international migration governance

Gülay Toksöz

Globalizations, volume 15, issue 6 (October 2018) pp. 779-794

\section{Chapter 5}

Repoliticizing international migration narratives? Critical reflections on the Civil Society Days of the Global Forum on Migration and Development

Kellynn Wee, Kudakwashe P. Vanyoro and Zaheera Jinnah

Globalizations, volume 15, issue 6 (October 2018) pp. 795-808 


\section{Chapter 6}

Making or unmaking a movement? Challenges for civic activism in the global governance of migration

Aleksandra Ålund and Carl-Ulrik Schierup

Globalizations, volume 15, issue 6 (October 2018) pp. 809-823

\section{Chapter 7}

The problem of representation: civil society organizations from Turkey in the GFMD process Cavidan Soykan and Nazlı Şenses

Globalizations, volume 15, issue 6 (October 2018) pp. 824-837

\section{Chapter 8}

Syrian refugees in Turkey and trade union responses

Seyhan Erdoğdu

Globalizations, volume 15, issue 6 (October 2018) pp. 838-853

\section{Chapter 9}

Angry birds of passage - migrant rights networks and counter-hegemonic resistance to global migration discourses

Stefan Rother

Globalizations, volume 15, issue 6 (October 2018) pp. 854-869

\section{Chapter 10}

'Getting to the root causes of migration' in West Africa - whose history, framing and agency counts?

Nora McKeon

Globalizations, volume 15, issue 6 (October 2018) pp. 870-885

For any permission-related enquiries please visit:

http://www.tandfonline.com/page/help/permissions 


\section{Notes on Contributors}

Aleksandra Ålund is a Professor Emerita at the Institute for Research on Migration, Ethnicity and Society (REMESO) at Linköping University, Sweden.

Raúl Delgado Wise is a Professor and the Director of the Doctoral Program in Development Studies at the Autonomous University of Zacatecas, Mexico.

Seyhan Erdoğdu is a Professor (retired) in the Faculty of Political Sciences, Department of Labour Economics and Industrial Relations at Ankara University, Turkey.

Zaheera Jinnah has a $\mathrm{PhD}$ in anthropology and a background in development studies and social work. She is a Researcher at the African Centre for Migration and Society at the University of the Witwatersrand, Johannesburg, South Africa.

Branka Likić-Brborić is a Professor Designate at the Institute for Research on Migration, Ethnicity and Society (REMESO) at Linköping University, Sweden.

Nora McKeon is a historian/political scientist by training. She teaches at Rome 3 University, Italy, and the International University College of Turin, Italy.

Stefan Rother is a Researcher and Lecturer at the Arnold-Bergstraesser-Institute, at the University of Freiburg, Germany.

Carl-Ulrik Schierup is a Professor Emeritus at the Institute for Research on Migration, Ethnicity and Society (REMESO) at Linköping University, Sweden.

Nazlı Şenses is an Assistant Professor at the Department of Political Science and International Relations at Başkent University, Ankara, Turkey.

Cavidan Soykan is a dismissed academic for peace. She was working as a Lecturer in Human Rights at Ankara University, Turkey, until 7 February 2017. She continues to write and teach as an independent researcher.

Gülay Toksöz was a Professor in the Department of Labour Economics and Industrial Relations at Ankara University, Turkey, but retired in 2016 due to political conditions.

Kudakwashe P. Vanyoro is a Research Communications Officer and Doctoral Researcher at the African Centre for Migration \& Society at the University of the Witwatersrand, Johannesburg, South Africa.

Kellynn Wee works as a Research Associate at the Asia Research Institute at the National University of Singapore. 


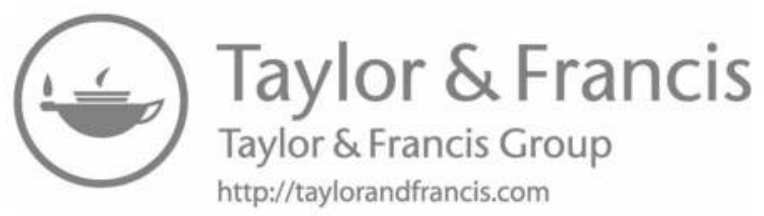




\section{Editors' Note}

On 19 December 2018 the General Assembly of the United Nations adopted the Global Compact for Safe, Orderly and Regular Migration (GCM), a comprehensive, but non-binding, global accord on a common roadmap for the management of migration agreed upon at an intergovernmental conference in Marrakech on 11 December 2018. The UN Global Compact for Migration (GCM) is a highly topical document, given that the issue of migration has advanced to the top of the agenda in international politics as well as in national states. But it is, as well, from its very inception, a highly disputed document. It is by its main architects as well as supportive civil society organizations (CSOs) and non-governmental organizations (NGOs) seen as a visionary accord: an outstanding historical achievement to the benefit of the lives of millions of people on the move. By critical CSOs and independent experts the GCM is, on the contrary, contested as a major retrogressive regime change through which corporate capital and states of the global North have found a means to counteract and marginalize binding conventions concerning human and labour rights; conventions designed to underpin an already existing legal, policy, institutional and practical governance system. Finally, the compact has been depicted by a concerted propaganda of the expanding extreme right to invite floods of culturally extraneous migrants: an impending apocalypse overpowering the endurance of incumbered nations.

The UN GCM is, whatever one's point of view on it, seen as an indicative accomplishment of more than a decade of global deliberations sparked by the United Nations High Level Dialogue on Migration in 2006 and carried forth, by, not least, yearly summits of the intergovernmental Global Forum on Migration and Development since 2007. It is a critical scrutiny of these processes, which is the central concern of the present collected volume, as they have unfolded in a series of different venues taking place in several countries, in the global South as well as the North and across regions of the world. The focus is on the impact of civil society groups and organizations on these processes concerned with the formulation of an overall normative framework for the governance of migration.

The chapters of this volume were first published as contributions to a special issue of the journal Globalizations in the summer of 2018 and written at a time when the conclusion of deliberations on the Global Compact for Safe, Orderly and Regular Migration was still pending. In the book we have added a short 'Postscript' written after the Compact's adoption by the United Nations in December 2018, discussing its meaning and consequences as seen from variable perspectives of CSOs that have participated as stakeholders in or in the capacity of external critics of the extended long-term deliberations grounding the Compact. 
Our work has benefitted from a Swedish Research Links grant by the Swedish Research Council 2014-17 [grant number 348-2013-6682], bestowed upon a Swedish-Mexican-Turkish research consortium based at the University of Linköping, the Autonomous University of Zacatecas and Ankara University. The grant has made possible the organization of a series of international researcherstakeholder workshops and conferences on migration, civil society and global governance, organized in Sweden, Mexico and Turkey, several of which have also benefitted from the support of the Swedish UNESCO-MOST Committee. We wish, as editors, to acknowledge the invaluable input of critical knowledge and experience offered by academics and civil society activists on these recurrent meetings. We acknowledge especially the collaboration of colleagues at the Department of International Relations; University of Freiburg; the African Centre for Migration and Society, University of the Witwatersrand, Johannesburg; the International University College (IUC) of Turin; the Asia Research Institute at the National University of Singapore; and Başkent University, Ankara, who have offered valuable contributions to this volume.

The Editors 


\title{
Migration, civil society and global governance: an introduction to the special issue
}

\author{
Carl-Ulrik Schierup, Branka Likić-Brborić, Raúl Delgado Wise and Gülay Toksöz
}

\begin{abstract}
The current special issue examines the development of an emerging global governance on migration and the spaces, roles, strategies and alliancemaking of a composite transnational civil society engaged in issues of rights and the protection of migrants and their families. This question is connected with how different actors - the United Nations, international organizations, governments and a wide variety of civil society organizations and regional and global trade unions - perceive the root causes of migration, global inequality and options for sustainable development. The contributions included in the special issue interrogate from different perspectives the positionality and capacity of civil society to influence the Global Forum for Migration and Development. They examine the opportunities and challenges faced by civil society in its endeavor to promote a rights-based approach within international and intergovernmental fora engaged in setting up a global compact for the management of migration and in other global policy spaces.
\end{abstract}

\section{A need for critical research}

The making of a de-commodifying, rights-based, global governance of migration is essential for the capacity to confront problems of unfree labor and the precarisation of livelihoods and citizenship. It concerns civil, social and labor rights for the protection of labor migrants, refugees and asylum seekers who constitute the most disadvantaged in many societies of both the global North and South. Their marginal representation calls for research on civil society in the global governance of migration and in other global policy spaces related to migration.

Following several international conferences and reports, ${ }^{1}$ the United Nations (UN) initiated a High Level Dialogue on International Migration and Development (UN-HLD) ${ }^{2}$ in 2006. And, in 2007, various governments launched the Global Forum on Migration and Development (GFMD). ${ }^{3}$ The GFMD was designed as a state-led, nonbinding and informal process, but figures as the most comprehensive arena for continuous intergovernmental deliberations between sending, receiving and transit states on emerging standards for the global governance of migration. It is also informed by the exchange of ideas with a plethora of international organizations, multilateral global and regional bodies (e.g. the Global Migration Group, GMG), ${ }^{4}$ business actors and a broad civil society,

This is an Open Access article distributed under the terms of the Creative Commons Attribution License (http://creativecommons.org/licenses/by/4.0/), which permits unrestricted use, distribution, and reproduction in any medium, provided the original work is properly cited. 
including migrant organizations, trade unions and non-governmental think-tanks. Given the growing relevance of migration in the international arena and the meagre results derived from the GFMD process to engender an institutional framework for the global governance of migration, in September 2016 the UN General Assembly endorsed the New York Declaration for Refugees and Migrants that set off an extensive intergovernmental consultation and negotiation process aimed at culminating with the adoption of a Global Compact for Safe, Orderly and Secure Migration by autumn-2018 (GCM) ${ }^{5}$ It is described as the 'first, inter-governmentally negotiated agreement, prepared under the auspices of the UN, projected to cover all dimensions of international migration in a holistic and comprehensive manner'.

Arrangements have been developed over the past years to include selected actors of civil society with the aim of instituting spaces for trust-building exchange between non-state and state actors. Since the inception of the GFMD, so-called 'Civil Society Days' ${ }^{6}$ (CSD) have been organized which precede the GFMD meetings. The CSD are currently managed by the Migration and Development Civil Society Network (MADE). ${ }^{7}$ A so-called 'Common Space', has been instituted as the interface between governments and civil society. Migrant and migrant advocacy actors in civil society have managed to continually expand their space for participation in these top-down processes while simultaneously establishing parallel events as autonomous spaces for deliberation and consensus-making between a multitude of variably positioned civil society organizations (transnational migrant organizations, trade unions, migrant advocacy civil society organizations (CSOs)); for example, the People's Global Action on Migration, Development and Human Rights (PGA). ${ }^{8}$ Invigorated and informed by alternative political visions forged at the World Social Forum (WSF) and in global networks such as the food sovereignty movement, their aim has been to mainstream alternative development and globalization models by framing them in global contexts such as UN conferences on climate change, women's rights, human rights, land rights and the ILO 'Decent Work Agenda' (DWA). Furthermore, they have established independent thematic chapters such as the World Social Forum on Migrations (WSFM) ${ }^{9}$ and civil society networks such as the Global Coalition on Migration. ${ }^{10}$ Particularly, the Global Coalition is actively engaged in leading civil society and migrant organizations in the GCM towards its adoption by Member States in 2018.

However, could the UN-initiated GFMD process indeed open the door for the representation of migrant civil society in, and impact on, a global governance of migration in transformation? This question is the focus of this special issue on Migration, Civil Society and Global Governance. The issue's overall theoretical approach is aligned with approaches in international political economy (e.g. Birchfield, 1999; Cox, 1977; Gill, 2005), combining influences from Gramsci and Polanyi in bridging international relations and the national scale of analysis. Taken in its broadest sense, Polanyi's notion of 'counter-movement' could be seen as an incipient theory of counter-hegemony. Today, as Gill (2003, p. 8) puts it:

[W] can relate the metaphor of the 'double movement' to those socio-political forces which wish to assert more democratic control over political life, and to harness the productive aspects of world society to achieve broad social purposes on an inclusionary basis.

This approach harnesses the essence of Polanyi's (1944/1957) theorem of the 'double movement', to a critical understanding of the present condition of globalization and its contestation, whether through policy regulation 'from above' (states and international organizations) or through civil society intervention 'from below'.

Based on these overall premises, the contributions of this issue set out, from different angles, to examine the development of an emerging global governance on migration and the spaces, roles, 
strategies and alliance-making of a composite transnational civil society pushing for a broad human rights-based approach to migration and development. The issue deals with the following questions: Will the factoring of migration politics into the UN 2030 Agenda for Sustainable Development ${ }^{11}$ affect changes in a fundamentally asymmetric neoliberal governance regime in ways that could facilitate civil society influence? What is the actual positionality and capacity of civil society organizations, engaged in the GFMD process, to re-politicise a dominant neoliberal migration narrative and, more specifically, to formulate game-changing approaches to the reproduction of informal labor and irregular migration from a rights-based perspective? Which dilemmas and which hegemonic politics of co-optation and appropriation are faced by 'inside-outside' ${ }^{12}$ strategies of composite civil society 'networks of equivalence' which endeavor to change the rules of the game in 'invited spaces $^{\prime 13}$ of global international and intergovernmental fora such as the UN-HLD, GFMD and GCM? How to foster links with other global governance fora relevant to migration, such as the Committee on World Food Security or the UN Human Rights Council, which arguably provide more congenial space for counterhegemonic civil society engagement. The issue discusses specifically the case of Turkey which is presented as a new immense strategic space and regional player in the governance of migration. This is addressed with emphasis on the ambivalent predicament of 'representation'. For example: How was the 'problem of migration' represented by agenda-setting governmental actors on the occasion of the GFMD summit in Istanbul in 2015? What was the actual 'representation' of migrants and their organizations in defining and managing 'the problem'? What is the agenda of Turkish trade unions concerning migration? Last, but not least, alternative narratives and strategies of contending movements of migrant organizations, migrant advocacy organizations, and trade unions are discussed. That is, civil society actors, global movements and events which follow alternative 'outside' strategies, critical towards a UNHLD-GFMD process which they see as co-opting, depoliticizing and neutralizing civil society agendas through appropriation. This is a question connected with how civil society organizations perceive the root causes of migration framed by an exclusivist neoliberal political economy and its contingent regime of migration management.

The current state of the art in research indicates that critical questions raised by this special issue have received relatively limited academic attention. Indeed, there is ample research on civil society and global governance in general (Betts, 2011; Buckley, 2013; Scholte, 2011; Smith, 2008; Tallberg, Sommerer, Squatrito, \& Jönsson, 2013). Further, it is argued that transnational activism can contribute to the transformation of global institutions (Smith, 2012, p. 9) particularly when priority voice is accorded to organizations representing social actors most affected by the policies under discussion (McKeon, 2015). Several studies on global governance have brought to attention that the engagement of CSOs could improve the democratization of global governance; in terms of enhanced participation and accountability, advancing global social justice and promoting an integrated approach to development. Nevertheless, these studies also warn for unsubstantiated optimism (cf., Bexell, Tallberg, \& Uhlin, 2010; Scholte, 2011). However, there are few studies on the role of CSOs in global and regional migration governance. Research on CSO involvement in the global governance of migration has been initiated by several scholars (e.g. Kalm \& Uhlin, 2015; Piper \& Grugel, 2015). Yet, existing studies of global governance of migration in general, and publications that address the case of GFMD in particular, focus on policy practices and documenting the process, but are - with certain exceptions (e.g. Geiger \& Pécoud, 2013; Rother, 2018; Schierup, Ålund, \& Likić-Brborić, 2015) - without critical theoretical ambitions. There is, claims Betts (2010), a connection between this relative absence of critical academic studies of migration as a global political topic and a lack of a global political vision in formulating effective migration policies that enhance human development and empower migrant agency. International migration has become a central theme of 
international politics; 'a bellwether theme, that decides elections and makes or breaks alliances' (Castles, 2018, p. 239). However, it is, as argued by Castles (2010), essential to investigate and theorise international migration and political regimes into which it is embedded, as profoundly integrated with studies of wider processes of neoliberal transformation.

\section{Stratagems of our current great transformation}

Seen in this perspective, migration is a critical component in broader processes of the erosion of social and labor rights and the institutionalization of precarity (Schierup, Hansen, \& Castles, 2006). New forms of niched labor markets are driven by the ways in which transnational migration is instrumentalised in the regulation and remaking of economies and contemporary societies in terms of the construction of institutionalized uncertainty. It produces 'precarious workers' over whom employers and labor users have particular mechanisms of control (Anderson, 2010, p. 300). The wider historical-structural context is the generation of a, multiple million strong, 'surplus population' over the past three and a half decades. It is a globally mobile reserve army of labor at the disposal of transnational corporations, sub-contractors and franchises; forged by austerity programs rolling back the social compacts of welfare and developmental states, and the spread of neo-colonial economies forging a predacious extractionism in the 'poorer nations' (Prashad 2012/ 2014) of the Earth. It has grown on the ruins of existing socialism in Eastern Europe, the Soviet Union and China. It has exploded due to the consequences of imperial wars scrambling for the Middle East and large parts of Africa in particular.

\section{The suppressed issue of irregular migration}

Piore (1979), for one, argued that international migration is driven by demands for a reserve army of labor staffing the secondary segment of 'dual labor markets'. Bauder (2006) goes, with reference to neo-Marxist regulation theory, beyond Piore, in exploring migration as integral to corporate and state strategies for actively shaping and regulating labor markets. Along similar lines, Slavnic (2010) analyses the informalisation of labor as a strategic instrument for current neoliberal restructuring connected with irregular migration as a clandestine regulatory instrument. Deepened informalisation - with irregular migration as an exemplary manifestation - is, Slavnic argues, contingent on a structural discrepancy between old Fordist and welfare statist modes of regulation and new, neoliberal, regimes of accumulation. Established regulatory frameworks become politically unacceptable to dominant power-blocks that see them as inadequate for embedding changing modes of accumulation. This implicates that all involved actors develop their own coping strategies, which move beyond existing regulatory frameworks that have habitually defined distinctions between formal and informal economic activities. Thus, the incremental informalisation of labor, the proliferation of grey ethnic labor market niches and irregular migration belong to evasive strategies for managing transition in a conjuncture. Here, the normative and legal regulatory regime is out of pace with modes of capital accumulation and hegemonic coalitions' uncompromising demands for 'flexibility' in terms of wage shrinking, diminished labor and social rights, contingent employment and de-unionisation. Refugees are, in the context of this process, thrown 'out of the frying pan' of the asylum system and 'into the fire' (paraphrasing Koser, 1998) of the informal economy where they keep company with illegalized migrants from the 'darker nations' (Prasad, 2008) of the global South and those precarious white migrants from the European East (Likić-Brborić, Slavnić, \& Woolfson, 2013), whom Sivanandan (Sivanandan, 2001) refers to in terms of 'poverty is the new black'. 
Thus, irregular migration and migrants' informal employment continue to feed the labor needs of a multitude of employers across the world, in the global North as well as in the South. It is about the hyper-exploitation of an abundant reserve of 'forced labour'; that is vulnerable workers caught in positions marked by a severe limitation of freedom of choice in the labor market and a high degree of external constraints or indirect coercion which take many different forms (ILO, 2007). A scrutiny of the reproduction of informal labor and irregular migration, and in particular the approach to the subject in an emergent global governance of migration, is therefore crucial. It is especially important, argues Gülay Toksöz in her contribution to this special issue, to interrogate the capacity of civil society to critically address the question, and formulate and drive constructive rights-based perspectives. She offers an analysis of irregular migration as a crucial form of forced migration, in the global North as well as in the South, and a comparative scrutiny of deliberations on the subject in 'Government Days' versus 'Civil Society Days' (CSD) across a series of GFMD summits. She argues that there is a reluctance to discuss the underlying causes behind the most precarious forms of migrant labor. This pertains, not least, to irregular migration and migrants' informal employment. She demonstrates that, while governments consistently emphasize circular migration as a remedy for regulating migration, civil society actors have been urging for rights-based policies, decent work and social protection, which could not totally be rejected by governments. The overall approach by governments has been to accept neoliberal globalization without questioning it. Root causes of irregular migration and the precarisation of labor in terms of uneven development have hardly been discussion themes in the government forum. In turn, discussions of the root causes in the CSD have most often been deferred in favor of developing piecemeal recommendations targeted at improving working and living conditions.

\section{A plurality of forced labour}

It is important to see informalisation and the rise of irregular migration as only one facet of a growing 'global migrant precariat' (Schierup \& Ålund, 2015). Neoliberalism does mean abandoning positive protective and redistributive regulation in welfare states of the North as well as developmental states of the South; not to speak of past state-bureaucratic planning and redistribution in Eastern Europe, the Soviet Union, China and other states of existing socialism. But it does not mean diminished regulation. What is colloquially called 'de-regulation' is actually a combination of de-regulation and re-regulation; in effect, meaning not less, but more, regulation (Standing, 2011). Majone (1997) conceptualizes this in terms of a regulatory state replacing a so-called 'positive', redistributive state. That is a state characterized by growing negative regulatory capacities for eliminating institutional and social obstacles to the commodification, or re-commodification, of labor, money and nature.

Applying the argument to the development of contemporary migration, we currently see a global tendency towards formally regulated, so-called, 'managed migration', with irregular migration increasingly criminalized. While the latter represents a prevalent vehicle for 'flexibilisation' in a post-Fordist conjuncture of transition, the former is a mode generated at a growing scale by a more 'mature' neoliberal regulatory state, in labor importing countries of the global South as well as the North. This refers, in particular, to the formalized, and mostly rigidly regulated, temporary and circular migrant workers schemes installed under the trade mark of 'managed migration'; an institutional alternative to mass irregularity gaining global political clout in the EU, NAFTA, the Gulf states, Australia, East and South-East Asia, and the Southern African Development Community (SADC). Governments meet employers' demands for cheap and 'flexible' labor, while seeking at the same time to appease xenophobic populism through employment practices which claim to avoid the 
'errors' of earlier policies that allowed migrants to settle and achieve gradual incorporation into denizenship or citizenship. They are matched by selective schemes for sifting off designated categories of resource endowed or professionally specialized migrant workers, judged valuable for the purposes of longer term settlement. ${ }^{14}$

Seen in the wider context of neoliberal globalization, temporary and circular migration - together with a range of other attempts at re-regulating migration (e.g. directives of the WTO) - constitute an integrated part of re-regulation practices driving the commodification or recommodification of labor. These develop in tandem with the restructuring of contemporary labor markets at large, and with the constitution of the regulatory state - alias the 'post-national workfare state' (Jessop, 2002) - embedded in regional communities such as the EU, NAFTA, ASEAN and SADC. We may thus understand 'managed migration' as one dimension of a disciplinary workfare but shifting access to rights and entitlements from the realm of social policy to that of migration management.

In contrast with, for example, post Second World War central European 'guest-worker' systems, which left legal-institutional openings or informal loop-holes for migrants to access citizenship (Guiraudon, 2000), most of the world's present-day temporary migration worker schemes are likely to be more rigorously monitored (Barrientos, 2007). Thereby, they also tend to be more deeply 'Apartheising' economies and societies (Galabuzi, 2006). Supposedly, win-win-win policies - combining migration and labor force management with development partnerships between receiving and sending countries (Triandafyllidou, 2013) - may per design contribute to restricted incorporation into the 'host-lands' of toil, while profiting from consigning lifelong social reproduction to native 'homelands'.

Temporary workers are usually bound to a single employer. They are notoriously difficult to organize, and thus the worldwide growth of schemes for circular and temporary migration is one of the most complex current challenges for trade unions and migrant and migrant advocacy organizations (Barrientos, 2007). There is, on this background, reasons to restate the argument by Mingione (1996) that different modes of exclusion cannot be understood in isolation but need to be investigated in mutual articulation within a wider conflict-laden social order. Schemes of temporary migration propel competition within precaritised labor markets (Schierup \& Castles, 2011). 'Undocumented' migrant workers and refouled asylum seekers are likely to still belong among the economically 'most needed'. But, contrasted with the formalized status of a growing category of heavily monitored temporaries, undocumented migrants' defamed 'status' as the politically 'least wanted' is likely to become exacerbated through further criminalization, securitization and public vilification, legitimized through the discourse of 'illegality'.

In his contribution to the special issue, Raúl Delgado Wise discusses this contemporary plethora of migrant categories in terms of forced displacement or forced migration generated by a discriminatory character of global capital accumulation. It is a phase of accumulation marked by an unprecedently concentrated and powerful monopoly capital. It is the nucleus of a discriminatory geopolitical order that produces a large variety of forced migration at the same time as it imposes restrictions on the mobility of migrants, subjecting them to conditions of vulnerability, precariousness and extreme exploitation. Contending movements of civil society need, in consequence, to challenge the politicaleconomic and geopolitical root causes of migration to encourage free circulation and decent work. But, whether they will be in position to do so remains a pending subject.

\section{What space for civil society in neoliberal governance?}

Proceeding from similar presuppositions, Branka Likić-Brborić sets out in her contribution to scrutinize the 'Paradoxes of Sustainability' embedded in global migration governance. Against the 
background of what she diagnoses as an asymmetric global governance, integral to neoliberal globalization, her contribution reviews the processes through which a global governance regime has been formulated, informed by the restatement of politics on migration and development in terms of factoring migration into the UN 2030 Development Agenda and the sustainable development goals (SDGs). She questions whether linking migration to this newly conceptualized governance for development will indeed hold the institutional capacity to address ground-causes of the deep precarisation of life and work brought about by the decades of top-down implementation of uniform development policies attuned to investment and free trade neoliberal development models. It appears that the UN's organizational architecture, attuned to the implementation of the SDGs, through the establishment of the High-Level Political Forum on Sustainable Development (HLPF), ${ }^{15}$ and made contingent on the mandate and required resources to promote hierarchical global economic governance, is insulated from democratic grievances, in a deeply regressive political economy. There is thus an urgent need for a serious interrogation of the potential of global civil society to resist persistent neoliberal globalization and an engrained free trade ideology undemocratically pushed for by the WTO and ongoing top-level negotiations.

The contribution by Kellynn Wee, Kudakwashe P. Vanyoro and Zaheera Jinnah on the question of 'Re-politicising International Migration Narrative' further interrogates the promises, potentials and limits to civil society in formulating and establishing an alternative counterhegemonic discourse within the context of the GFMD. Interrogating the GFMD-CSD forum as a hybridized, experimental and fluidly-defined discourse-led' global space, they probe into the validity of Antoine Pécoud's conceptualization of international organizations' (IOs) 'migration narratives' as representing a 'depoliticized' approach to migration. Contrary to this, the GFMD-CSD and the upcoming GCM, under UN auspices, are here seen to offer a certain openness and alternative to the IOs' generally static and technocratic migration narratives. It is therefore, they argue, pertinent to adopt a complex perspective on what de-politicization and re-politicization mean, and conceivably to 'reimagine' the GFMD-CSD as a space that continues to offer unique, albeit basically discursively and institutionally circumscribed, opportunities for contestation, opposition and politicization.

\section{Movement politics across 'invented' and 'invited' spaces}

Buckley (2013) emphasizes that counter-hegemonic politics should reconceptualise 'global civil society' in terms of 'transversal hegemony' as a subject of resistance against a 'transverse optimum' of a neoliberal hegemony. By understanding global civil society as 'a realm of contesting ideas', not just social groups, she proposes the understanding of global civil society as a historical concept, encompassing accumulated knowledge and imaginations of alternatives, and dialectically positioned to reality. Purcell (2009) suggests, along complementary lines, a fruitful way of moving forward in understanding the critical potential of still fragmented civil society actors that expands beyond the prevalent forms of class-based analyses and includes a multitude of ongoing struggles against variable contemporary forms of domination. He argues for a need to focus on 'networks of equivalence', that can come through collaboration between different social movements as a collective articulation of counter-hegemonic political values. It is an articulation through which the sameness and difference between groups blend, without dissolving differences into a homogenous unity. As a result, a coalitional group 'could arise from and be carried forward by multiple subject positions' (Purcell, 2009, p. 293).

The contribution by Ålund and Schierup to this special issue brings the salience of forming and continuously reproducing contending 'networks of equivalence' to bear on an analysis of the long- 
term trajectory of People's Global Action on Migration, Development and Human Rights, the PGA, stretching over two consecutive UN-HLD meetings and a series of GFMD summits. The GFMD summit in Mexico, 2010, the UN-HLD in New York, 2013 and subsequent GFMD summits in Stockholm, 2014 and Istanbul, 2015, are described as breaking points in terms of direction, impact and embeddedness of the PGA's particular 'inside-outside' strategy for making alternative civil society conceptions of migration, development and human rights bear on the global governance on migration. The paper combines a conceptualization and analytical operationalization of transversal politics and networks of equivalence with the notions of 'invited' and 'invented' spaces, inspired by the work on contentious social movements by Gaventa (2006), Miraftab (2004) and others. The PGA developed as the hub of a global movement of civil society; an ideotypical example of a global network of equivalence which focused, under the banner of 'human rights', on what had been identified as widely shared issues of dispossession and social justice with activists representing the global South at the forefront. From dominant perspectives of migrant organizations and migrant advocacy NGOs/INGOs, it vied for the rapport with powerful, but every so often ambivalent, allies among global unions. It devised a dual 'inside-outside' strategy for impacting debates in the GFMD and in particular its 'invited spaces' (the CSD and Common Space) for government-civil society deliberations, but empowered by preparatory debates and analyses in the context of its own autonomous 'invented space' for deliberation across a worldwide plural network of migrant organizations and migrant advocacy NGOs/INGOs. The study presented here exposes an inclusionary, but selective and subordinating, hegemony management and appropriation of movement objectives by governments, business interests, powerful international organizations and chosen gate-keeping humanitarian INGOs such as the International Catholic Migration Commission (ICMC) ${ }^{16}$ It underlines a necessity for contending movements to continuously critically recreate and consolidate their own 'invented spaces', in order to be able to develop a sustainable capacity as counter-hegemonic political subjects.

\section{The Turkish case in focus}

Turkey's development from a country of high emigration into one of high immigration in the 2000s is a remarkable case of social transformation. Moreover, Turkey's role as a country and a cardinal node in the international migration system surged with the reception of close to four million refugees after the start of the war in Syria (2011), which made Turkey one of the most important refugee receiving countries of the world. In the 2000s, Turkey has adopted several laws directed towards the regulation of labor migration and the rights of asylum seekers and their families (e.g. Erdoğdu \& Şenses, 2015). On this background, it is not by chance that Turkey took on the role of organizing the GFMD summit in Istanbul in 2015. In their contribution to this volume on 'the Problem of Representation', Cavidan Soykan and Nazlı Şenses discuss the positionality of Turkish CSOs in the Istanbul summit. They take their point of departure in Alexander Betts' (2012, p. 12) concept of 'facilitative multilateralism', with respect to facilitating dialogue between states and civil society. In the context of the GFMD, this would implicate the representation of migrants and their claims for rights. This pushes a critical theoretical discussion of the concept of 'representation' to the fore. Yet the CSD of the Turkish GFMD remained a heavily monitored 'invited space' without significant migrant representation including positions with the potential to incorporate a potent migrant voice, with the host (the government) in firm control of 'representing the problem' of migration. Civil society representation from Turkey was not diversified or representative of the country's millions of diversified migrants; therefore, a problematic 'problem of representation'. There was a conspicuous absence of Turkish trade unions and trade union reports with other 
civil society actors, as well as the discussion of the country's numerous refugees from the perspective of labor. In conclusion, there was, seen from a critical perspective, no basis for a meaningful facilitative multilateralism in the Istanbul GFMD.

Seyhan Erdogdu further contextualizes the problem of the representation of migrants and of migrants, and in particular refugees, in her text on 'Syrian Refugees in Turkey' and trade union responses to their presence. She argues that this problem needs to be framed against a general background of shrinking union inclusion in Turkey. A solidaristic rhetoric and attempts to forge inclusive union policies dominant on the confederal union level dovetails with the Turkish government's 'open door' politics towards Syrian refugees. However, at a lower organizational and day to day operational level, refugee issues are hardly to be found on the agenda. Despite demands for the formal and regulated employment of refugees, at the workplace level, union positionality is generally exclusive and stigmatizing. There is a conspicuous lack of articulation between central unions and the workplace level. Imaginaries among union members are characterized by worries concerning a perceived negative impact of large scale refugee presence, and in particular refugee labor, on employment and wages, working conditions and the bargaining power of local labor, as well as on access to housing, education, health and social assistance. This general situation of stalemate in the positionality of Turkish labor unions may be part of an explanation for their conspicuous absence, rather than a forceful representation, in a Turkish GFMD generally steered by a business-friendly representation of problems rather than by concerns of unions and labor.

\section{Alternative trajectories}

In his contribution 'Angry Birds of Passage' on migrant rights networks and counter-hegemonic resistance to global migration discourses, Stefan Rother takes his point of departure in a discussion of positionalities among global civil society actors confronting and rejecting a hegemonic neoliberal discourse on the global governance of migration in general, and the GFMD process in particular. The focus is on an analysis of strategies and prospects for establishing counter-hegemonic movements, here represented by the International Migrants Alliance (IMA). A central tenet of the current hegemonic block driving the present neoliberal governance of migration is that of an overly repeated but under-defined notion of 'circular migration' as the pivot for a narrative of 'migration and development'. Praised by dominant policy-makers and think-tanks, circular migration appears as a benign way of upholding a world hegemony for which migrant labor circulates as a cheap commodity to be controlled, disciplined and 'managed'; 'unfree labour' alienated from fundamental social and labor rights, and resources and avenues for contestative collective organization. The migration and development slogan has also opened spaces for migrant and civil society voices as discussed across contributions to this special issue. However, in contrast to the 'inside-outside' strategy followed by, for example, the PGA (discussed in the contribution by Ålund and Schierup), others have remained 'outsiders by choice'. The IMA, for one, stands for a global alliance of organizations of grassroots migrants, refugees and displaced people contesting the GFMD agenda. This is viewed as a network of networks contending 'NGOism'; a civil society alliance which claims to be run 'by migrants for migrants'. At the same time, the forum provides them with opportunities to organize their own counter-space, continuously challenging the governments and international organizations involved in the GFMD process.

The paper by Nora McKeon provides a critical regional West African perspective on the 'root causes' of irregular migration, the European 'migration crisis' and a situation of increasing EU 'policy ambivalence' characterized by two different policy packages with opposed impacts promoted by powerful economic interests seeking profits from investments in African agriculture that dispossess 
peasants, on the one hand, and politically opportunistic xenophobic defenders of European security, on the other. She suggests that this contradiction might open opportunities for alternative policies rooted in alliances among social movements and organizations in Africa and Europe, drawing on the evidence and claims of the West African peasant movement whose cogent policy alternatives have been largely neglected in hegemonic framings of 'migration and development'. Their voices, and those of other components of the food sovereignty movement contrasting the rural dispossession that generates involuntary migrants, are heard most strongly at the global level in the UN Committee on World Food Security in which they participate on the same footing as governments.

Finally, the already mentioned contribution to this issue by Raúl Delgado Wise takes the question of civil society in global governance back to the fundamentals of contemporary capitalism and brings to the forefront a broad alternative global counter-hegemonic trajectory. He points towards the potential of the WSFM as an alternative 'invented space' with reach, legitimacy and organizational clout to potentially challenge the neoliberal win-win-win mantra of 'managed migration'. Departing from the foundational principles of the World Social Forum, the WSFM is an 'invented space' designed to link civil society organizations and movements in a permanent process of seeking and building alternatives.

In conclusion, the potential of organizations located at the crossroads of 'invented' and 'invited' spaces in the context of migration governance should not be neglected but their opportunities are limited, judged from the research presented in this special issue of Globalizations. Short time concessions may be obtained. However, the risks for depoliticizing co-option and appropriation would support the case for moving at a distance from the relative comfort of 'invited' spaces and into a more independent counterhegemonic field of contention, or for strategically transversing between the two, but ensuring the survival and growing strength of the independent 'invented' spaces. At the same time, there is a need to strengthen networking and convergence among movements that adopt different entry points to the same struggle, from fighting 'managed' migration to contesting corporate control of food and land.

\section{Notes}

1. GCIM (2005), WCSDG (2004).

2. Overview of the UN process available at http://www.un.org/en/development/desa/population/ migration/events/ga/index.shtml.

3. Information on The Global Forum on Migration and Development available at http://www.gfmd.org/.

4. Information on the Global Migration Group available at http://www.globalmigrationgroup.org/.

5. Information on the CGM available at https://www.iom.int/global-compact-migration. Ongoing negotiations on the GCM bring critical conflicts concerning the access of migrants to basic rights to the fore between states differentially positioned in an asymmetric global division of labor (e.g. CELS_e_INEDIM, 2018).

6. See e.g. http://www.madenetwork.org/gfmd.

7. Information available at the MADE homepage http://madenetwork.org/.

8. Information on the People's Global Action on Migration, Development and Human Rights available at, e.g. http://peoplesglobalaction.org/about/history/ and http://peoplesglobalaction.org/.

9. Information on the World Social Forum on Migrations available at http://fsmm2018.org/8th-worldsocial-forum-migrations-mexico-2018/?lang=en.

10. Information on the Global Coalition on Migration available at http://gcmigration.org/.

11. Information on the UN 2030 Agenda for Sustainable Development available at https://www.un.org/ sustainabledevelopment/development-agenda/.

12. A notion used by, for example, Rother (2009). 
13. The use of the notions of 'invited' and 'invented' spaces across several papers in this special issue is based, chiefly, on the work of Miraftab (2004).

14. See for example critical discussions of 'managed migration' and 'circular migration' by Fudge and Strauss (2013) and Wickramasekara (2011).

15. Information on the HLPF available at https://sustainabledevelopment.un.org/hlpf.

16. Information on the ICMC available at https://www.icmc.net/.

\section{Acknowledgements}

This introduction and the Globalizations special issue on Migration, Civil Society and Global Governance is a product of the Swedish Research Links project, 'Migration and development. What space for civil society in global governance?' (MIGLINK). The MIGLINK project was developed in collaboration between researchers at Linköping University, Sweden, the Autonomous University of Zacatecas, Zacatecas, Mexico and Ankara University, Turkey with financial support through the Swedish Research Council [grant number 348-2013-6682].

\section{Disclosure statement}

No potential conflict of interest was reported by the authors.

\section{Funding}

This work was supported by the Swedish Research Council [grant number 348-2013-6682]. 


\section{References}

Anderson, B. (2010). Migration, immigration controls and the fashioning of precarious workers. Work, Employment \& Society, 24(2), 300-317.

Barrientos, S. (2007, March 26-28). Migrant and contract labour in global production systems: Addressing decent work for the most vulnerable workers. Prepared for the Living on the Margins Conference, Stellenbosch.

Bauder, H. (2006). Labor movement: How migration regulates labor. Oxford: Oxford University Press.

Betts, A. (2010). The refugee regime complex. Refugee Survey Quarterly, 29(1), 12-37.

Betts, A. (2011). Introduction: Global migration governance. In A. Betts (Ed.), Global migration governance (pp. 1-34). Oxford: Oxford University Press.

Betts, A. (2012). Global migration governance. Oxford: Oxford University Press.

Bexell, M., Tallberg, J., \& Uhlin, A. (2010). Democracy in global governance: The promises and pitfalls of transnational actors. Global Governance, 17, 81-101.

Birchfield, V. (1999). Contesting the hegemony of market ideology: Gramsci's 'good sense' and polanyi's 'double movement'. Review of International Political Economy, 6(1), 27-54.

Buckley, K. M. (2013). Global civil society and transversal hegemony. The globalization-contestation nexus. London and New York, NY: Routledge, Taylor and Francis Group.

Castles, S. (2010). Understanding global migration: A social transformation perspective. Journal of Ethnic and Migration Studies, 36(10), 1565-1586.

Castles, S. (2018). Social transformation and human mobility: Reflections on the past, present and future of migration. Journal of Intercultural Studies, 39(2), 238-251.

CELS_e_INEDIM. (2018). Actualización del estado de las negociaciones intergubernamentales del Pacto Global de Migración: La cuarta ronda.

Cox, R. W. (1977). Labour and hegemony. International Organization, 31(1), 385-424.

Erdoğdu, S., \& Şenses, N. (2015). Irregular migrant labour, trade unions, and civil society organizations in Turkey. In C.-U. Schierup, R. Munck, B. Likic-Brboric, \& A. Neergaard (Eds.), Migration, precarity and global governance. Challenges and opportunities for labour (pp. 177-198). Oxford: Oxford University Press.

Fudge, J., \& Strauss, K. (2013). Temporary work, agencies and unfree labour. Insecurity in the new world of work. In J. Fudge \& K. Strauss (Eds.), Temporary work, agencies, and unfree labor. Insecurity in the new world of work (pp. 1-25). New York: Routledge.

Galabuzi, G.-E. (2006). Canada's economic apartheid: The social exclusion of racialized groups in the new century. Toronto: Canadian Scholars' Press Inc.

Gaventa, J. (2006). Finding the spaces for change: A power analysis. IDS Bulletin, 37(6), 23-33.

GCIM. (2005). Migration in an interconnected world: New directions for actions. Geneva: Global Commission on International Migration.

Geiger, M., \& Pécoud, A. (Eds.). (2013). Disciplining the transnational mobility of people. Houndmills: Macmillan.

Gill, S. (2003). Gramsci, modernity and globalization. Rome: International Gramsci Society.

Gill, S. (2005). New constitutionalism, democratisation and global political economy. In R. Wilkinson (Ed.), The global governance reader (pp. 174-186). London: Routledge.

Guiraudon, V. (2000). The Marshallian triptych reordered: The role of courts and bureacracies in furthering migrants' social rights. In M. Bommes \& A. Geddes (Eds.), Immigration and welfare. Challenging the borders of the welfare state (pp. 72-89). London: Routledge.

ILO. (2007). For debate and guidance, the informal economy. Geneva: ILO.

Jessop, R. D. (2002). The future of the capitalist state. Cambridge: Polity.

Kalm, S., \& Uhlin, A. (2015). Civil society and the governance of development. Opposing global institutions. Baingstoke: Palgrave MacMillan.

Koser, K. (1998). Out of the frying pan and into the fire: A case study of illegality amongst asylum seekers. In K. Koser \& H. Lutz (Eds.), The new migration in Europe. Social constructions and social realities (pp. 185-198). Houndmills: Macmillan.

Likić-Brborić, B., Slavnić, Z., \& Woolfson, C. (2013). Labour migration and informalisation: East meets west. International Journal of Sociology and Social Policy, 33(11-12), 677-692. 
Majone, G. (1997). From the positive to the regulatory state: Causes and consequences of changes in the mode of governance. Journal of Public Policy, 17(2), 139-167.

McKeon, N. (2015). Food security governance: Empowering communities, regulating corporations. Abingdonon-Thames: Routledge.

Mingione, E. (1996). Urban poverty and the underclass: A reader, studies in urban and social change. Oxford: Blackwell.

Miraftab, F. (2004). Invited and invented spaces of participation: Neoliberal citizenship and feminists' expanded notion of politics. Wagadu, 1(Spring), 1-7.

Piore, M. J. (1979). Birds of passage: Migrant labor and industrial societies. Cambridge: Cambridge University Press.

Piper, N., \& Grugel, J. (2015). Global migration governance, social movements and the difficulties of promoting migrant rights. In C.-U. Schierup, R. Munck, B. Likic-Brboric, \& A. Neergaard (Eds.), Migration, precarity and global governance. Challenges for labour (preliminary title) (pp. 261-279). Oxford: Oxford University Press.

Polanyi, K. (1944/1957). The great transformation: The political and economic origins of our time. Boston, MA: Beacon Press.

Prasad, V. (2008). The darker nations. New York, NY: The New Press.

Prashad, V. (2012/2014). The poorer nations: A possible history of the global south. London and New York, NY: Verso.

Purcell, M. (2009). Hegemony and difference in political movements: Articulating networks of equivalence. New Political Science, 31(3), 291-317.

Rother, S. (2009, April). 'Inside-outside' or 'outsiders by choice'? Civil society strategies towards the 2nd Global Forum on Migration and Development (GFMD) in Manila. Asien, 111, 95-107.

Rother, S. (2018). The Global Forum on Migration and Development (GFMD) as a venue of state socialization: A stepping stone for multi-level migration governance? Journal of Ethnic and Migration Studies, 44. doi:10. 1080/1369183X.2018.1441605

Schierup, C. U., \& Ålund, A. (2015). Un precariado global migrante. Fuerza de trabajo, diudadania y espacio para la sociedad civil. In G. Hernández, G. Margarita, D. Tetreault, \& H. M. Covarrubias (Eds.), Senderos de la insustentabilidad. Degradación humana y ambiental en el capitalismo neoliberal (pp. 83-126). Zacatecas: Universidad Autónoma de Zacatecas.

Schierup, C.-U., Ålund, A., \& Likić-Brborić, B. (2015). Migration, precarization and the democratic deficit in global governance. International Migration, 53(3), 50-63.

Schierup, C.-U., \& Castles, S. (2011). Migration, minorities and welfare. In N. Phillips (Ed.), Migration in the Global Political Economy (pp. 15-40). Boulder and London: Lynne Rienner.

Schierup, C.-U., Hansen, P., \& Castles, S. (2006). Migration, citizenship and the European welfare state. A European dilemma. Oxford: Oxford University Press.

Scholte, J. A. (Ed.). (2011). Building global democracy? Civil society and accountable global governance. Cambridge: Cambridge University Press.

Sivanandan, A. (2001). Poverty is the new black. An introduction (also book reviews). Race \& Class/the Journal of the Institute of Race Relations, 43(2), 1-5.

Slavnic, Z. (2010). Political economy of informalization. European Societies, 12(1), 3-23.

Smith, J. (2008). Social movements for global democracy. Baltimore: John Hopkins University Press.

Smith, J. (2012). Transnational activism and global social change. In H. Mosknes \& M. Melin (Eds.), Global civil society. Shifting powers in a shifting world (pp. 9-26).

Standing, G. (2011). The precariat. The new dangerous class. London: Bloomsbury Academic.

Tallberg, J., Sommerer, T., Squatrito, T., \& Jönsson, C. (2013). The opening up of international organizations. Transnational access in global governance. Cambridge: Cambridge University Press.

Triandafyllidou, A. (Ed.). (2013). Circular migration between Europe and its neighbourhood. Choice or necessity? Oxford: Oxford University Press.

WCSDG. (2004). A fair globalization: Creating opportunities for all. Geneva: ILO.

Wickramasekara, P. (2011). Circular migration: A triple win or a dead end [da]. Geneva: Global Union Research Network (GURN). GURN Discussion Paper, 15. Geneva: International Labour Office (ILO). 


\title{
Is there a space for counterhegemonic participation? Civil society in the global governance of migration
}

\author{
Raúl Delgado Wise
}

\begin{abstract}
Based on a Marxist analytical framework, this article offers a contextualized and critical overview of the participation of civil society in the global governance of migration. Derived from an analysis informed by direct involvement in the most important invited and invented spaces for civil society in the incipient and fragile process of global migration governance, it argues that: (a) the space for counterhegemonic participation of civil society is essentially marginal given the increasing penetration of neoliberal institutions in promoting a dominant 'Northern' discourse on migration and development, and migration management as a mainstream policy; and (b) under capitalism there is no space for a counterhegemonic agency of global governance. Therefore, resistance from below as a creative process of social transformation is the only option for building a socially just international migration regime. This 'invented space' is an articulation of anti-systemic social movements, networks, and other civil society organizations.
\end{abstract}

\section{Introduction}

Migration is a critical topic on the international agenda. According to recent UN figures, there are 258 million international migrants (UN, 2017a) and 750 million internal migrants worldwide (Swing, 2015). One out of every seven and a half inhabitants and one of every four members of the working class is a migrant, in most cases exposed to vulnerable, discriminatory and precarious labour conditions (ILO, 2015a). Regardless of the strategic importance of this phenomenon, migration studies and public perceptions of human mobility are fraught with myths that distort reality under a unilateral, de-contextualized, reductionist, and biased view. The recent refugee crisis in Europe has hardened this narrative and exacerbated the problems and challenges posited by migration in the international arena.

The dominant political and research agendas in the field tend to reproduce - not disinterestedly much of the prevailing mythology, ignoring the context in which contemporary migration takes place and its root causes. They assume human mobility is a free and voluntary act, oblivious to any kind of structural conditioning and/or national or supranational agents. The multiple economic, demographic, social, and cultural contributions made by migrants to host societies and nations are often ignored, hidden or even distorted, regardless of their legal status and categorization (economic migrants, refugees, asylum seekers, etc.). To this end, migrants are frequently portrayed as socioeconomic burdens for destination countries, and in times of crisis, turned into public scapegoats. 
In line with the recognition of the critical challenges propelled by human mobility, the global governance of migration has become a fundamental issue on the international agenda. In contrast to other transnational issues such as trade and finance, the creation of a UN institutional framework for the governance of migration has followed a complex and uncertain route (Betts, 2010). The non-ratification of the 1990 UN Convention on the Rights of All Migrant Workers and Their Families by most migrant-receiving countries exemplifies the inherent complexity and limitations of this endeavour.

Derived from the need to discuss pressing issues on the international migration agenda, a broader initiative for building a global migration regime was envisaged at the UN General Assembly in 2006 with its launch of the High-Level Dialogue on Migration and Development (UN-HLD). This was conceived of as a formal event with a strong emphasis on policy issues that would be held at the UN headquarters every seven years. The first UN-HLD gave rise to the creation of a yearly stateled, non-binding, related Forum, alternatively hosted by migrant-receiving and migrant-sending countries, namely: The Global Forum on Migration and Development (GFMD). To provide institutional support for this emerging process, the UN Secretary-General created an interagency coordinating mechanism, the Global Migration Group, integrated by 15 entities of the UN system 'to promote the wider application of international and regional instruments and norms relating to migration and to encourage the adoption of more coherent, comprehensive and better coordinated inter-agency approaches' (IOM, 2017). It is important to note that the World Bank has stood as a key member of this Group - as well as many other UN initiatives - playing a leadership role in establishing the dominant framework within which the debates surrounding the migration-development nexus have been entrenched.

In September 2016, the UN General Assembly formally designated the International Organisation for Migration (IOM) as the UN migration agency. On that occasion, the New York Declaration for Refugees and Migrants was adopted by its 193-member states, giving rise to an intergovernmental consultation and negotiation process that will culminate with the adoption of a Global Compact for Safe, Orderly and Secure migration by mid-2018. This initiative was at the centre of the 10th GFMD celebrated in Berlin in June 2017, and is gaining momentum in the many regional consultations scheduled worldwide to come up with an institutional framework for global migration governance. Two competing and contrasting positions have been at stake since the inception of the GFMD and continue to be present in the current debate: a dominant policy perspective centred on migration management versus an alternative view referred to as a human rights comprehensive approach (Delgado Wise, Márquez, \& Puentes, 2013; Pécoud, 2015).

Although one of the proclaimed objectives of the GFMD ${ }^{1}$ - as expressed on its official webpage - is to 'engage with other stakeholders, including non-governmental organizations, experts and migrant organizations to foster practical and action-oriented outcomes at national, bilateral and international level', for civil society it remains essentially an 'invited' space (Miraftab, 2004; Ålund \& Schierup, 2018) with limited possibilities for participation and interaction with governments. This is an argument grounded by knowledge, as well as derived from my personal, direct participation and involvement - as an academic and activist - for more than a decade of consecutive UN-HLD and GFMD venues. During this period, I have also participated in consecutive parallel meetings staged in global fora constituted as essentially autonomous 'invented spaces' (Miraftab, 2004; Ålund \& Schierup, 2018), specifically: the People's Global Action on Migration, Development (PGA) and the World Social Forum on Migration (WSFM) initiated by migrant organizations, networks and movements, human rights NGOs and labour unions, federations and confederations. Although the first space (PGA) has challenged the dominant discourse with 
limited results, the second space (WSFM) represents a truly invented space that departs radically from the dominant agenda, and is struggling to promote, in theory and practice, a counter-hegemonic block that addresses the root causes of the current dominant form of migration as described below. On this background, the purpose of this paper is to critically assess the participation of civil society in and impact on the formation of global migration governance with emphasis on the GFMD process.

\section{Forced migration in the era of generalized monopolies}

Neither the nature of contemporary migration nor the attempts to advance towards an institutional framework for the global governance of migration can be assessed without a deep understanding of the current capitalist context. In this regard, the increasing monopolization of finance, production, services, and trade, leaving every major global economic activity to be dominated by a handful of large multinational corporations, prevails as one of the most salient features of contemporary capitalism, to the extent that Samir Amin (2014) has portrayed it as the 'era of generalized monopolies'. Through mega-mergers and strategic alliances, monopoly capital has reached unparalleled levels of concentration and centralization: in 2014, the top 500 largest multinational corporations acquired 31.2 trillion USD in sales revenues (Fortune, 2015), equal to 40 per cent of the world's GDP (World Bank, 2017). More important is the fact that, in the neoliberal era, monopoly capital has undergone a profound restructuring process characterized by:

(1) The upsurge of monopoly finance capital; i.e. the ascendancy of finance capital over other fractions of capital. With the lack of profitable investment in production, capital began shifting towards financial speculation based on an unprecedented reserve of fictitious capital. The result has been the financialization of the capitalist class, industrial capital, and corporate profits (Foster, 2010).

(2) The configuration and expansion of global networks of monopoly capital as a restructuring strategy led by the large multinational corporations, which, through outsourcing operations and subcontracting chains, extends parts of their productive, commercial, financial, and service processes to the Global South in search of abundant and cheap labour through global labour arbitrage (Delgado Wise \& Martin, 2015). This turn towards global production chains has been impressive: '[the] top one hundred global corporations had shifted their production more decisively to their foreign affiliates [mainly in the South], which now account for close to 60 percent of their total assets and employment and more than 60 per cent of their global sales' (UNCTAD, 2010).

(3) The restructuring of innovation systems through the implementation of mechanisms such as outsourcing (including offshore) the scientific and technological innovation process, which allows multinational corporations to benefit from the research of scientists from the Global South. This restructuring reduces labour costs, transfers risks and responsibilities, and capitalizes on the advantages of controlling the patent process (Delgado Wise, 2015; Delgado Wise \& Chávez, 2015). The rhythm of patenting has increased exponentially in the last two decades, associated with the logic underlying 'free trade' agreements as an imperialist strategy for controlling/ administrating global markets by large MNCs, mainly based in the US.

(4) The renewed trend towards extractivism and land grabbing, led by the continuing over-consumption of the world's natural resources and the expansion of carbon-based industrial production. This new extractivism has worsened environmental degradation, not only through 
an expanded geography of destruction, but also by global extractive capital's strategy of environmental regulatory arbitrage. Given that the revenues of some of the world's most powerful and profitable multinational corporations depend on fossil fuel consumption, this pattern will likely continue, setting the world on the path towards a deepening ecological crisis.

A major and inescapable feature of the current form of capitalism, neoliberal globalization, is uneven development. The global and national dynamics of capitalist development, the international division of labour, the imperialist system of international power relations, and the conflicts that surround the capital-labour relation and the dynamics of extractive capital have made economic, social, political, and cultural polarization more extreme between geographical spaces and social classes than ever before in human history. A conspicuous output of this scenario is the disproportionate concentration of capital, power, and wealth in the hands of a small elite within the capitalist class. Nowadays, the richest $1 \%$ of the world's population controls $40 \%$ of total global assets (Davies, Sandström, Shorrocks, \& Wolff, 2008). Moreover, 'from 1970 to 2009, the per capita GDP of developing countries (excluding China) averaged a mere 6.3 percent of the per capita GDP of the G8 countries' (Foster, McChesney, \& Jonna, 2011).

In fostering the above trend, global labour arbitrage has become a key pillar of the new global architecture. This allows capital to appropriate enormous monopolistic returns, or imperial rents, by taking advantage of the huge national wage differentials existing across the North-South divide, and the existence of subsistence (and below) wages in much of the Global South. Through the mechanism of global labour arbitrage, social and geographic asymmetries are reproduced on a global scale. Social inequalities are one of the most distressing aspects of this process, given the unprecedented concentration of capital, power and wealth in a few hands, while a growing segment of the population suffers poverty, exploitation, and exclusion. Increasing disparities are also expressed, ever more strongly, in terms of: racial, ethnic and gender relations; reduced access to production and employment; a sharp decline in living and working conditions; and, the progressive dismantling of social safety nets.

The aforementioned implies an unprecedented attack on the labour and living conditions of the working class. With the dismantling of the former Soviet Union, the integration of China and India into the world economy and the implementation of structural adjustment programmes (including privatization and labour reforms) in the Global South, the supply of labour available to capital over the last two decades has more than doubled from 1.5 to 3.25 billion, in what Richard Freeman (2006) calls the 'Great Doubling'. This has led to an exorbitant oversupply of labour which has scaled down the global wage structure and increased the overall precariousness of labour. According to estimates of the International Labour Organisation (ILO), the number of workers in conditions of labour insecurity rose to 1.5 billion in 2017 - encompassing nearly half of the world's labour force - with 800 million receiving a salary of less than 3 US dollars per day, while the global number of unemployed continues to rise (ILO, 2018). These conditions - which are unevenly distributed worldwide - have led to growing structural pressures to emigrate internally and/or internationally under conditions of extreme vulnerability.

Under these circumstances, migration is not merely the product of individual or family decisions - as postulated by the neoclassical school of thought - but a phenomenon with its own patterns, embedded in a set of social networks and transnational relations. The massive scale of migration in the neoliberal era and the bond between domestic and international flows are fundamentally determined by the contradictory and disorderly dynamics of uneven development. Migration thus adopts the mode of 'compulsive displacement', i.e. a new modality of forced migration, possessing 
the following two characteristics. First, migration is essentially an expulsion process resulting from a downward spiral of social regression triggered by the deprivation of production means and subsistence, pillaging, violence, and catastrophes that jeopardize the survival of large segments of the population in places of origin. This is not simply a cumulative or gradual process, but an actual breakdown of the social order brought about by structural adjustment policies, domination and wealth concentration strategies, which have attained extreme levels and are forcing massive contingents of the population to sell their labour power both nationally and internationally to guarantee their families' subsistence. Second, compulsive displacement imposes restrictions on the mobility of the migrant workforce, depreciating and subjecting it to conditions of high vulnerability, precariousness, and extreme exploitation. If the process of expulsion is a reprisal of the original accumulation modes characteristic of the first historical stages of capitalism, the current liberalization of the workforce is fated to face obstacles in the labour market internationally. Migrant-receiving states regulate immigrant entry with punitive and coercive instruments that devalue labour, in addition to violating human rights and criminalizing migrants. Conditions for labour exploitation and social exclusion, as well as risks experienced at different stages of transit and settling, endanger the lives of migrants (Márquez \& Delgado Wise, 2011).

In this context, migration has acquired a new role in the national and international division of labour. Uneven development generates a new type of migration that can broadly be characterized as forced migration. Although the conventional concept of 'forced migration' does not apply to all migrants (Castles, 2003), most current migration flows are forced displacements, and therefore require a more accurate descriptor. In the field of human rights, the term 'forced migration' refers specifically to asylum seekers, refugees or displaced people. However, as I have been arguing, the dynamics of uneven development have led to structural conditions that foster the massive migration of dispossessed, marginalized and excluded populations. Under these circumstances, migration has essentially become a forced population displacement encompassing the following modalities (Delgado Wise \& Márquez, 2009):

(1) Migration due to violence, conflict, and catastrophe. Social, political and communitarian conflicts, natural disasters, major infrastructure developments and urbanization can severely affect communities, social groups, families, and individuals, to the point of forcing them to abandon their place of origin and sometimes their country. This category includes refugees, asylum seekers and displaced people. These modalities, which tend to mainly affect populations in the Global South, have been acknowledged in international law and there are protection instruments in place. According to the United Nations High Commissioner for Refugees' figures, there are 65.6 million worldwide, including 22.5 million refugees, 40.8 million internally displaced and 3.2 million asylum seekers (UNHCR, 2015).

(2) Human trafficking and smuggling. This modality of forced displacement has increased at an alarming rate in recent years, becoming a highly lucrative business due to the restrictive policies of receiving countries and increasing hardship in less developed ones. Human trafficking is associated with coercion, abduction, and fraud, and includes sexual exploitation and illicit adoptions among other serious violations of human rights. The global response to the sustained increase in this form of criminal activity - which has become an increasingly profitable one for organized crime - includes the United Nations' Convention against Transnational Organized Crime, signed in Palermo in 2000, and the subsequent Protocol to prevent, suppress and punish the trafficking of people, especially women and children. It is estimated that at 
least 21 million people are currently engaged in forced labour because of internal and international human trafficking (ILO, 2015b).

(3) Migration due to dispossession, exclusion, and unemployment. As argued in this section, most current labour migration falls under this category, which is characterized by extreme vulnerability, criminalization, discrimination, and exploitation. It is by far the largest category of forced migration, encompassing around 600 million international and internal 'economic' migrants. Instead of adequately categorizing the problems and risks to which these migrants are exposed, they are generally subsumed under the notion of 'economic migrants', which assumes they travel in a context of freedom and opportunities for social mobility in transit and destination countries, ignoring the growing vulnerability, insecurity and forced disappearances to which these migrants are subjected.

(4) Return migration in response to massive deportations. This is a growing trend in international migration associated with the irregular status faced by an increasing proportion of migrants derived from a State policy by destination countries - not a criminal act. It entails a process of double forced migration: they were forced to leave their countries of origin and then forced to return under increasingly vulnerable and insecure conditions.

In a less strict sense, migration due to over-qualification and a lack of opportunities can be considered as a fifth type of forced migration. It ensues from the restructuring of innovation systems and structural imbalances in the labour market as well as limited institutional backing in peripheral countries which result in many highly qualified workers being unable to find suitable occupation opportunities in their own country. This category of forced migration encompasses nearly 30 million professionals (OECD-UNDESA, 2013). While these migrants do not face serious problems when moving or seeking to cover their basic needs, they migrate to fulfil their labour and intellectual capacities, even if they are often subjected to labour degradation and wage discrimination in destination countries.

\section{The participation of migrant civil society in the UN-HLD and GFMD}

In the context of neoliberal restructuring and the emergence of what has been described as forced migration in the international arena, a new discourse regarding migration and development emerged:

Suddenly, 'migration and development' is the flavour of the month. For many years politicians and officials in labour-importing countries have seen South-North migrants as a problem for national identity and social cohesion, and more recently even as a threat to national security. Now such policy-makers are doing everything to emphasize the potential benefits of international migration for the countries of origin. (Castles \& Delgado Wise, 2008, p. 3)

Why this new concern? Because, as I shall argue, linking migration to development was a strategy to control migratory flows and maximize its benefits for the receiving countries through migration management and as a tactical move for securing cooperation from southern (origin and transit) countries. In this regard, the debate surrounding the UN-HLD and GFMD has been marked by a dispute between two competing and contrasting positions. The first one, which underlines the rationale of mainstream migration policies promoted by the World Bank (WB), IOM, International Centre for Migration Policy Development, Organization for Security and Cooperation in Europe, Organization of American States, and other multilateral agencies and think tanks, such as the 
Migration Policy Institute, has been conceptualized as migration management (Ghosh, 2008). Under the umbrella of an apparently 'neutral' notion, new narratives have been promoted beneath this label. The attempt is to 'depoliticise' migration, obfuscate the existence of divergent interests or asymmetries of power and conflicts, avoid obligations imposed by international law, and promote the idea that managing migration can be beneficial for all stakeholders: countries of destination, countries of origin, migrants themselves and their families. This unrealistic triple-win scenario clearly favours the interests of the migrant-receiving countries and large multinational corporations based in such countries (Geiger \& Pécoud, 2010, 2013). In the rhetoric of migration management: (a) neoliberal globalization is taken for granted and not considered as part of the migration, development and human rights 'problematique' (Boucher, 2008); (b) a 'good migrant', regardless of his or her status and conditions, is flexible to market needs and eager to contribute to the development of his country of origin; (c) irregular migration is regarded as a problem generated outside the migrant-receiving country, ignoring its internal motivations (corporate demand for cheap and flexible labour) and the role of the State in spawning 'illegality' through limiting channels for 'legal' entrance far beyond actual labour and demographic needs (Geiger \& Pécoud, 2010); (d) temporary or guest workers' programmes are one of the best tools for regulating labour markets, ignoring the fact that guest workers are held virtually captive by employers or labour brokers who seize their documents, enabling high levels of exploitation, discrimination and social exclusion (Southern Poverty Law Center, 2007); (e) return policies, either forced or voluntary, assume places of origin will benefit from the abilities, skills, and values acquired by migrants in receiving societies; and (d) transit countries should prevent irregular migration flows to destination countries through the reinforcement of border control activities and counter-smuggling and trafficking efforts.

In contrast with this dominant view, civil society has played an important role in the debate within the UN-HLD and GFMD - particularly during the civil society days (CSDs) and occasionally in the common space launched in Mexico in 2010 - as an alternative approach that centres on migrants' human rights, gaining terrain in the deliberations with the support of migrant-sending countries and civil society participants. This approach seeks to contextualize the migration problematic by focusing on and attempting to explain the geopolitics and geoeconomics of uneven development and social inequalities in contemporary capitalism. From this viewpoint, neither migration nor development is approached as independent variables; they are inscribed within the broader historical context of neoliberal globalization. At the same time, the relationship between migration and development is approached from a multidimensional perspective that encompasses economic, political, social, environmental, cultural, racial, ethnic, gender, geographical, and demographic factors (Castles \& Delgado Wise, 2008; Delgado Wise \& Márquez, 2009; Faist, 2009; Glick Schiller, 2009; Piper, 2016; Portes, 2009). This alternative vision on the relationship between migration and development has been conceived, in contrast to migration management, as a human rights-centred approach.

While migration management is centred in a national security doctrine, the alternative approach prioritizes a human security framework. The former is tailored by a pattern that disregards human rights, vindicating corporate-driven public policies and temporary workers programmes as mainstream migration policies. This approach also embraces the remittances myth or mantra (Castles \& Delgado Wise, 2008; Kapur, 2004) as a façade to hidden growing asymmetries among regions and countries, and social inequalities as root causes of contemporary migration. In contrast, the alternative approach is based on a human rights overarching vision that promotes equitable and sustainable human development. Rather than opposing national sovereignty (versus the national security doctrine), it attempts to tackle the root causes of the problematic and not only its consequences, encouraging free circulation regimes and decent work for everybody. 


\section{Civil society participation in the global governance of migration}

Although the UN-HLD and GFMD - as core engines of the global governance of migration - are essentially inter-governmental spaces, the participation of civil society in both spaces is viewed and recognized in the following terms:

Owing to its State-led nature, the primary purpose of the Forum [GFMD] is to facilitate a constructive dialogue among governments. Yet another important objective is to enhance coherence in policy making and institution building - at the national, regional and international levels - where civil society actors are considered as contributors and partners. Civil society input to GFMD activities and dialogue between governments and civil society is thus recognized as both useful and necessary. (GFMD, official webpage)

Theoretically, the category of civil society refers to institutions and organizations that are not confined strictu sensu to the State apparatus. According to Gramsci, State and civil society cannot be conceived of as entirely independent and separate entities; beyond the porous border existing between them, the latter cannot be subsumed to the former (Pereira, 1979). Civil society is by no means homogeneous, it encompasses different groups, organizations, non-State institutions and social movements that reflect contrasting and, in many cases, opposing interests in terms of the Gramscian concept of hegemony, namely, the exercise of class domination by the State through a combination of coercion and persuasion.

For analytical purposes, following a neo-Gramscian perspective, i.e. envisioning civil society as an arena for hegemonic and counterhegemonic practices (including both a war of movement and a war of position) in the realm of international relations (Carroll, 2007; Cox, 1987; Van der Pijl, 1984), it is possible to identify two contrasting participants in the UN-HLD and GFMD:

(a) Independent human rights and class-orientated grassroots organizations with a counterhegemonic potential, such as migrant organizations and networks, migrant advocacy NGOs, trade unions, peasant movements, faith organizations, and critical academia.

(b) Mainstream organizations supportive of the dominant ideological discourse on migration and development, including State-led NGO's, Northern think tanks and corporate-driven agents.

Regarding these two distinctive civil society constituencies - each of them clearly aligned with one of the two confronting positions in debate at the UN-HLD and GFMD -there are two additional issues worth considering. First, due to the adverse prevailing conditions for human mobility described in the previous section, migrant organizations are confronted with several congenic constraints for their formation as political subjects. Their levels of political organization, consciousness and leadership at a global scale are still limited. This is also the case of migrant advocacy NGOs and other independent human rights and class-orientated grassroots organizations. However, the incipient participation of trade unions, peasant movements, faith organizations, and progressive academia within and outside these invited spaces - as will be analysed in the following sections - may potentially lead to the configuration of networks of equivalence, i.e. ' ... broad coalitions of movements and groups that expose the political field as "irreducibly plural", merging sameness and difference in terms of identity and agenda' (see Ålund \& Schierup, 2018).

Second, the institutional framework of the UN-HLD and GFMD is moving in a direction that privileges the business sector over other civil society participants. In this regard, civil society has been officially defined by the UN as " ... the "third sector" of society, along with government and business'. This implies a critical differentiation that is not naïve or accidental. It embraces a clear revaluation of participant roles within the UN system: 
The relationship of the UN and the international business community has been transformed. Business entities embracing corporate responsibility now work side by side with the Organization to make the world a better place. Through the UN Global Compact, companies embrace ten universal principles, from supporting the protection of human rights, to working against corruption. At the recent Climate Summit in New York, corporations made commitments to help mitigate climate change. The international business community now wants to partner with the international community to help solve humanity's problems. This is not only good global citizenship on their part. It is also good business. ${ }^{2}$

In the 10th edition of the GFMD, June-July 2017, the business sector did not openly participate in the CSDs programmed activities and instead participated as a special guest in the inter-government fora, and as another separate entity in the common space (originally conceived as a space for government-civil society interaction).

\section{Assessment of the participation of civil society in the UN-HLD and GFMD}

In the first meetings of the UN-HLD and GFMD, the space for civil society participation was essentially marginal and scattered. Many of the organizations participating in the CSDs were not representative or even concerned with the migrant community in their regions or countries of origin. In addition, there were limited connections among civil society participants and virtually no interaction channels with government delegates. After the CSDs-GFMD in Brussels, these circumstances began to change. The progressive convergence of civil society participants with a PGA parallel event - as an outsider/insider space - opened a unique alternative space for networking and developing a human rights-centred agenda. The PGA-CSD connection, established at the GFMD celebrated in Mexico in 2010, became a watershed in this process. After this edition of the GFMD, where the common space was launched, the responsibility for the organization of the CSDs previously conferred to businessled foundations, ${ }^{3}$ was transferred to an organization directly linked with migrant issues and which was previously engaged in the PGA-CSD connection: The International Catholic Migration Commission (ICMC). Since then, the ICMC has been responsible for organizing CSDs in Switzerland, Mauritius, Sweden, Turkey, Bangladesh, and Germany/Morocco, as well as the 2013 UN-HLD in New York. ${ }^{4}$

Many contributions to the debate on migration and development, particularly in support of the migration governance framework, were made under the leadership of the progressive wing of civil society participants at the UN-HLD and GFMD. A key achievement and landmark of this process was 'the 5-year, 8-point action plan' position paper supported by hundreds of civil society organizations and networks from around the world and delivered to the 2013 UN-HLD. Beyond this significant accomplishment, which was incorporated into the final declaration of the 2013 UN-HLD, it is important to recognize that: (a) the formal/institutional participation of civil society in the invited spaces under consideration remains a chimera; (b) there has been a reiterative failure of the GFMD to implement and follow-up agreements, including the main resolutions approved by consensus in the UN-HLD; ${ }^{5}$ (c) there has been a pendular process surrounding the debate on migration and development with a clear regressive trend manifested in the last GFMD where, inter alia, the government Forum was programmed prior to the CSDs, the business sector was given preferential status and many topics of the migration management perspective were reincorporated into the agenda, such as the relaunch of temporary migration workers' programmes as an example of 'good practice' in the mainstream package of migration policies; (d) within the landscape of civil society representatives, the participation of potential counterhegemonic allies such as trade unions and peasant organizations continues to be incipient and even declining; and e) the ICMC - 
the institution commissioned by the GFMD establishment to organize the CSDs - has lost much of its autonomy in defining the civil society agenda to the point that there is a growing suspicion of cooption among allied organizations (Rother, 2018).

As previously mentioned, at the UN General Assembly celebrated in September 2016, a process of intergovernmental consultations and negotiations was set in motion: The Global Compact for Safe, Orderly and Secure Migration. This initiative was at the centre of the 10th GFMD agenda which took place in Berlin in June 2017, and is gaining momentum in the many regional consultations supported by the IOM, scheduled to come up with a worldwide, institutional framework for global migration governance by September 2018. It cannot be emphasized enough that in the many position papers that have been produced throughout the Global Compact process, including the report of the UN Secretary-General, 'Making migration work for all' (UN, 2017b), there have been significant efforts to change the dominant narrative on migration. Notwithstanding the high expectations that this process raised, and the extraordinary impulse given to it by its two co-facilitators, Mexican Ambassador Juan José Gómez Camacho and Swiss Ambassador Jürg Lauber, with the active and erudite role played by the Special Representative for International Migration appointed by the UN Secretary-General, Louise Arbour, unfortunately - given the nature of contemporary migration and the still dominant neoliberal transnational historic bloc ${ }^{6}$ - its final outcome is uncertain. The negative perceptions of migrants that permeate public opinion in most destination countries, the meagre outcomes of the 10th GFMD and the decision of the US not to participate in the process, stand as bad omens. In this regard, the observation made by Alexander Betts seven years ago (2010, p. 1) - 'the overall picture of global migration governance remains incoherent, poorly understood, and lacks an overarching vision' - continues to mirror the main challenges faced by counterhegemonic organizations and movements for building a socially just international migration regime capable of promoting free circulation standards and decent work for everybody.

\section{Resistance from below}

\section{The PGA and emergence of an umbrella organization, the global coalition on migration}

Since its inception, the PGA has been conceived of as a space of migrant organizations, migrant-led organizations, academia and trade unions parallel to - but increasingly linked with - the UN-HLD and GFMD. As previously mentioned, this space has broadened civil society participation and opened an autonomous venue for debate and convergence regarding strategic issues on migration, development, and human rights. It can be conceived of as an 'invented space' allocated at the crossroads of an 'invited space'.

Without denying the important role played by the PGA - through its events and demonstrations - it is important to recognize that throughout its 11 editions (New York, 2006; Brussels, 2007; Manila, 2008; Athens, 2009; Mexico, 2010; Geneva, 2011; New York, 2013; Mauritius, 2014; Stockholm, 2015; Dhaka, 2016; and Berlin-Morocco, 2017-2018), it has suffered from: (a) a weak organizational and strategic planning structure with different degrees of engagement by local organizations; (b) scarce financial resources; and (c) recurrent difficulties in securing new potential allies. Given that the PGA was born in parallel to the UN-HLD and GFMD, several questions regarding its potential as an 'inv space' remain open: Is the PGA a space for participatory democracy as opposed to the top-down logic prevailing in the invited space? If so, to what degree and with what scope and limitations does it give voice to grassroots migrant organizations and its allies? And, through its connection with the intergovernmental fora, is it challenging or legitimating the dominant system of migration governance? 
In this regard, an important outcome associated to the PGA process has been the creation of the Global Coalition on Migration (GCM), formally launched on December 2011 in Geneva, Switzerland. In contrast to the PGA, the GCM's geography and calendar are not necessarily tied to the UN-HLD and GFMD events. Its membership comprises regional and international networks of migrant associations, migrant rights organizations and advocates, trade unions, peasant movements, faith groups and academia, with worldwide regional presence. ${ }^{7}$ Most GCM members have been participating in the PGA, but have also been involved in the WSFM, which - as will be addressed in the following section - represents the most important invented counterhegemonic space in the global migration field. Notwithstanding its potential for engendering a counterhegemonic social movement (Ålund \& Schierup, 2018), most of the current efforts of the GCM are concentrated on participation in the Global Compact on Migration process:

As a coalition of mainly migrant and migrant-led organizations, GCM is emphasizing that migrants are both stakeholders in the Global Compact process and rights-holders, and will participate as fully and effectively as possible in the consultations and negotiations culminating in the Global Compact. We seek to demonstrate strong civil society support for upholding existing human rights norms and instruments, engaging with states and other stakeholders to support the effective implementation of these instruments, and to oppose any provisions that could undermine these norms and their implementation - particularly in the contexts of detention, returns/deportations, trafficking and smuggling. ${ }^{8}$

The potential of the GCM to transcend the limitations of an invited space and move towards the realm of an invented space '... occupied by the grassroots and claimed by their collective action, but directly confronting the authorities and the status quo ... in the hope of larger societal change and resistance to the dominant power relations' (Miraftab, 2004, p. 1) and thus capable of challenging the root causes of forced migration, remains a pending subject.

\section{The world social forum on migration: A space of resistance and rebellion from below}

The WSFM:

... is one of the thematic processes of the World Social Forum. The WSFM, like [the] WSF, is a space for [the] democratic debate of ideas, reflection, formulation of proposals, exchange of experiences; for [the] articulation of social movements, networks, NGOs and other civil society organizations opposed to neoliberal globalization. [The] WSFM is a space to discourse and discuss mobility-focused topics, e.g. the political, economic, social and cultural rights of migrants, displaced, refugees and stateless persons, issues of restrictions on citizenship and civil rights. The WSFM is a global process that seeks what is possible to build an alternate world order; a society directed towards fruitful relationships between humans and with the land, thus consolidating a globalization of solidarity. ${ }^{9}$

More specifically, departing from the charter of foundational principles of the WSF, the WSFM is envisaged as: (i) '.. an open meeting space for reflective thinking, [the] democratic debate of ideas, [the] formulation of proposals, [the] free exchange of experiences and interlinking for effective action'; (ii) a plural and diverse Forum 'that, in a decentralized fashion, interrelates organisations and movements engaged in concrete action at levels from the local to the international to build another world'; (iii) '... a permanent process of seeking and building alternatives, which cannot be reduced to the events supporting it', where the '... alternatives proposed ... stand in opposition to a process of globalization commanded by the large multinational corporations and by the governments and international institutions at the service of those corporations interests, with the complicity of national governments'; and (iv) a space that ' ... seeks to strengthen and create new national and international links among organizations and movements of society, that ... increase the capacity for 
non-violent social resistance to the process of dehumanization the world is undergoing and to the violence used by the State' (WSF, 2001).

To date, there have been seven editions of the WSFM: Porto Alegre, 2005; Rivas-Vaciamadrid, 2006 and 2008; Quito, 2010; Manila, 2012, Johannesburg, 2014; and Sao Paulo, 2016. The next WSFM will be held in Mexico City in November 2018. Although there has been an effort to broaden the international scope of the Forum to European, Asian and African locations, half of its venues have been granted to Latin American organizations and networks. Most of the member organizations and networks of the International Committee (IC) are from Latin America, stamping a regional rather than a global imprint on the Forum. To this end, the turnover of IC members and the inclusion of new ones is an important pending issue.

A dilemma underlying the WSF process lies with the fact that ".. its mission as "an open space" (stated as the first clause of its Charter of Principles)' is placed against 'the aspiration of many activists to transform it into a global social justice movement' (Carroll, 2007, p. 50). The dispersion of its constituencies across many sites and networks, including issues of translation - from language to language, culture to culture, local to global - stands as another limitation (Santos, 2005).

Due to the scant resources of the participating organizations, particularly grassroots migrant organizations, there are two interrelated challenges faced by the WSFM as an invented space: (a) the need for alliances and coalitions with other counterhegemonic actors (beyond migrant and migrant-led organizations, such as trade unions and peasant and indigenous movements) ${ }^{10}$; and (b) the difficulties for advancing towards the constitution, expansion, and consolidation of networks of equivalence. Related to this, an organic connection between the WSFM and its mother Forum, the WSF, stands as another imperative matter.

A critical issue in the WSFM process has been its financial support. So far, the support for each biennial venue has primarily relied on financial resources and facilities granted by city-governments. However, in the last two editions of the Forum - Johannesburg and Sao Paulo - changes and cooption attempts by local and national authorities put in jeopardy the realization of the event, and posited the need to diversify the funding sources in order to gain broader financial autonomy.

Given the great challenges for maintaining, expanding and consolidating this alternative, counterhegemonic invented space for the VIII edition of the WSFM, which will be held in Mexico City, a restructuring process of the Forum is being discussed and under construction. This is in line with the reengineering process being conducted within the WSF, with the aim of broadening the scope and diversity of the organizations, networks and social movements involved, as well as improving autonomy, fostering the development of open, free and horizontal organizational structures, focussing on the root causes of the current migration problematic with a prefiguration (i.e. social transformation) focus, and developing an action plan that interconnects actions, campaigns and struggles at global, regional, and local levels.

\section{Concluding remarks}

The analysis of the participation of civil society, and particularly the participation of its progressive counterhegemonic - wing in the UN-HLD and GFMD processes, as privileged spaces where the global governance of migration process is being conducted, have demonstrated not only the limited progress achieved in tackling the migration and development problematic, but most importantly, the limited possibilities to mark out a space for civil society participants (with the notable exception of the business sector). Moreover, the Global Compact process for safe, orderly and secure migration - where migrant and migrant-led organizations have been actively engaged in regional consultations - will most likely end up with a nicely framed declaration that will not address the most pressing issues and demands posited 
by the migrant community. The withdrawal of the US (the main migrant-receiving country in the world) is a clear signal in this regard. Most significantly, I have shown that the institutions responsible for the global governance of migration are being progressively penetrated by neoliberal institutions - such as the World Bank - that are the de facto powers; the key institutional players behind the current imperialist and corporate-driven 'world order'. In other words, the field upon which the global governance of migration is playing out is not neutral and the rules of the game have been imposed by the hegemonic neoliberal transnational bloc.

Beyond the limitations of the invited spaces under scrutiny, the participation of civil society in the UN-HLD and GFMD has had an important by-product that should not be underestimated, namely: the formation of a potentially counterhegemonic bloc linked to two alternative but interconnected independent spaces, the PGA and GCM. Both spaces are allocated at the crossroads of an invented and an invited space. To remain in-between is a possibility, but it is a limited option. In the political scenario, there are essentially two contrasting possibilities: to continue cloistered in an invited space or to advance towards the consolidation of an alternative counterhegemonic space (Ålund \& Schierup, 2018). The first option is essentially confined to the possibility of achieving short-term concessions with the risk of co-option, and the second implies moving apart from the relative 'comfort' of the invited space and entering to a counterhegemonic battlefield; i.e. the space of the anti-systemic social movements and the WSFM. In the first case, the logic implied is that of replication, and in the other, the logic of prefiguration (Carroll, 2007, p. 53): 'The groups comprising the neoliberal bloc follow a logic of replication. For counterhegemonic groups, the social relations that might sustain an alternative way of life are immanent, emergent, or need to be invented' (Carroll, 2007, p. 54).

Given that under capitalism there is no space for a counterhegemonic agency of global governance, resistance from below - envisaged as a process of alliance building at various levels - can be regarded as the only option for building a socially just international migration regime. This implies an important redefinition of the traditional notion of resistance (passive and reactive), for a radically different conception as envisioned and practiced by the Zapatista movement, and means:

... changing 'the resistance struggle into a transformative struggle' capable of building a new a society free of all exploitation, deprivation, repression and disparagement in the reclaimed spaces under its control. But this not only requires the creation of islands of resistance, but rather archipelagos ... that challenge the capitalist system with an emancipatory vision and under a liberating and revolutionary rationale. (Delgado Wise \& Martínez, 2017, pp. 149-150)

The restructuring process in which the WSFM is engaged represents an important step in the configuration of a counterhegemonic bloc. Critical social movements are essentially concerned with broad structural problems and transformations. Beyond their specific demands they tend to establish unity among diversity and perhaps more importantly: ' $\ldots$ to challenge the "constitutive principles of the existing political order" through rethinking meanings of power, resistance and de-legitimation and extending "the boundaries of the possible"' (Buckley, 2013, p. 93). The motto of the WSF 2018 clearly reflects this position: 'to Resist is to Create, to Resist is to Transform pointing to the need for alternatives for another possible world'. ${ }^{11}$

\section{Notes}

1. https://gfmd.org/.

2. http://www.un.org/en/sections/resources-different-audiences/business/.

3. King Baudouin Foundation in Brussels; Ayala Foundation in the Philippines; Onassis Foundation in Athens; and the Bancomer Foundation in Mexico. 
4. With the leadership of the ICMC, an umbrella organisation was created: The Migration and Development Civil Society (MADE) Network, aimed at strengthening civil society's thematic knowledge and expertise at regional and global levels, mainly focussing on the GFMD process. This initiative was sponsored by two core European Commission-funded projects: Migration and Development Improving Migration and Development Partnerships and Action with Civil Society, and Strengthening the GFMD Civil Society Network on Migration and Development. Several key organisations participating in the independent human rights and class-orientated grassroots GFMD CSDs were incorporated into the MADE network.

5. It is worth adding that at the core of the global legal regime for migration governance there are three complementary, sequential instruments specifically on international migration: ILO Convention 97 on migration for employment of 1949, ILO Convention 143 on migrant workers (supplementary provisions) of 1975, and the subsequent 1990 International Convention on the Protection of the Rights of All Migrant Workers and Members of Their Families. All three contain complementary norms for the governance of migration and provisions for international dialogue and cooperation, as well as specific standards recognising the human rights of migrant workers and their families. None of these instruments have been ratified by the bulk of migrant-receiving countries, evidencing the historical inoperancy of the different efforts to institutionalise a migration governance regime in the international arena, which unfortunately still continue.

6. In reference to ' $\ldots$ an assemblage of elite policy-planning organizations, transnational corporations, and global-governance organizations that has promoted, and to some extent consolidated, a hegemonic project of neoliberal globalization' (Castles \& Delgado Wise, 2007, p. 36).

7. http://gcmigration.org/members/.

8. http://gcmigration.org/projects-campaigns/compact/.

9. http://apmigration.ilo.org/events/world-social-Forum-on-migrations.

10. Some of the characteristics of the social movements in Latin America, which stand at the forefront of the new and new/new social movements worldwide are: territorialisation, autonomy, direct democracy, the reaffirmation of culture and identity, the formation of its own intellectuals, new roles for women, collective and horizontal organisation of work, innovative ways of developing the productive forces orientated to social necessities and harmony with nature. Following Gramscian terminology, these movements are engaged in an anti-systemic, counterhegemonic struggle in two battle fronts: a 'war of position' and a 'war of movement'.

11. https://fsm2016.org/en/en-route-vers-le-forum-social-mondial-2018/.

\section{Disclosure statement}

No potential conflict of interest was reported by the author.

\section{Funding}

This article is a contribution to the Swedish Research Links project, 'Migration and development. What space for civil society in global governance? (MIGLINK)', with financial support through the Swedish Research Council [grant number 348-2013-6682]. 


\section{References}

Ålund, A., \& Schierup, C.-U. (2018). Making or unmaking a movement? Challenges for civic activism in the global governance of migration. Globalizations. doi:10.1080/14747731.2018.1446599

Amin, S. (2013). The implosion of capitalism. London: Pluto Press.

Betts, A. (2010). Global migration governance - the emergence of a new debate. Briefing Paper. Department of Politics and International Relations, University of Oxford, UK. Retrieved from http://www.geg.ox.ac.uk/ sites/geg/files/Betts\%20Global\%20Migration\%20Governance\%20PB.pdf

Boucher, G. (2008). A critique of global policy discourses on managing international migration. Third World Quarterly, 29, 1461-1471.

Buckley, K. M. (2013). Global civil society and transversal hegemony: The globalization-contestation nexus. London: Rouledge.

Carroll, W. K. (2007). Hegemony and counter-hegemony in a global field. Studies in Social Justice, 1(1), 36-66.

Castles, S. (2003). Towards a sociology of forced migration and social transformation. Sociology, 37, 13-34.

Castles, S., \& Delgado Wise, R. (2008). Migration and development: Perspectives from the South. Geneva: IOM.

Cox, R. W. (1987). Production, power, and world order. New York, NY: Columbia University Press.

Davies, J., Sandström, S., Shorrocks, A., \& Wolff, E. (2008). The world distribution of household wealth. United Nations University: World Institute for Development Economics Research (Discussion Paper No. 2008/03). Retrieved from http://citeseerx.ist.psu.edu/viewdoc/download?doi $=10.1 .1 .337 .440 \& \mathrm{rep}=$ rep1\&type $=\mathrm{pdf}$

Delgado Wise, R. (2015). Unraveling Mexican highly-skilled migration in the context of neoliberal globalization. In S. Castles, M. Arias Cubas, \& D. Ozkul (Eds.), Social transformation and migration: National and local experiences in South Korea, Turkey, México and Australia (pp. 201-218). London: Palgrave MacMillan.

Delgado Wise, R., \& Chávez, M. (2015). Patentad, patentad: Apuntes sobre la apropiación del trabajo científico por las grandes corporaciones multinacionales. Observatorio del Desarrollo, 4(15), 22-29.

Delgado Wise, R., \& Martin, D. (2015). The political economy of global labour arbitrage. In K. Van der Pijl (Ed.), The international political economy of production (pp. 59-75). Cheltenham: Edward Elgar.

Delgado Wise, R., \& Martínez, A. (2017). Hacia un nuevo horizonte emancipatorio: Contribuciones del zapatismo a la teoría y práctica revolucionarias. Theomai. Estudios críticos sobre Sociedad y Desarrollo, 35, 142-156.

Delgado Wise, R., Márquez, H., \& Puentes, R. (2013). Reframing the debate on migration, development and human rights. Population, Space and Place, 19(4), 430-443.

Delgado Wise, R., \& Márquez, H. (2009). Understanding the relationship between migration and development: Toward a new theoretical approach. Social Analysis, 53, 85-105.

Faist, T. (2009). Transnationalization and development: Toward an alternative agenda. Social Analysis, 53, 38-59. Fortune. (2015). Global 500. Retrieved from http://fortune.com/global500/

Foster, J. B. (2010). The financialization of the capitalist class: Monopolyfinance capital and the new contradictory relations of ruling class power. In H. Veltmeyer (Ed.), Imperialism, crisis and class struggle: The enduring verities and contemporary face of capitalism (pp. 191-201). Leiden, MA: Brill.

Foster, J. B., McChesney, R. W., \& Jonna, J. (2011). The Internationalization of Monopoly Capital. Monthly Review, 63(2), 3-18.

Freeman, R. B. (2006). The great doubling: The challenge of the new global labor market. Retrieved from https:// eml.berkeley.edu/ webfac/eichengreen/e183_sp07/great_doub.pdf

Geiger, M., \& Pécoud, A. (2010). The politics of international migration management. London: Palgrave Macmillan.

Geiger, M., \& Pécoud, A. (2013). Disciplining the transnational mobility of people. London: Palgrave Macmillan.

Ghosh, B. (2008). Derechos humanos y migración: el eslabón perdido. Migración y Desarrollo, 10, 37-63.

Glick Schiller, N. (2009). A global perspective on migration and development. Social Analysis, 53, 14-37.

International Labour Organization. (2015a). ILO global estimates on migrant workers. Results and methodology. Geneva: Author.

International Labour Organization. (2015b). Forced labour, human trafficking and slavery. Retrieved from http://www.ilo.org/global/topics/forced-labour/lang--en/index.htm

International Labour Organization. (2018). World employment and social outlook: Trends 2018. Geneva: Author. 
International Organization for Migration. (2017). United Nations High-Level Dialogue on International Migration and Development (UN-HLD). Retrieved from https://www.iom.int/united-nations-high-leveldialogue-international-migration-and-development-hld

Kapur, D. (2004). Remittances: The New Development Mantra? (Discussion Paper). Washington, DC: World Bank.

Márquez, H., \& Delgado Wise, R. (2011). Signos vitales del capitalismo neoliberal: imperialismo, crisis y transformación social. Estudios Críticos del Desarrollo, 1(1), 11-50.

Miraftab, F. (2004). Invited and invented spaces of participation: Neoliberal citizenship and feminists' expanded notion of politics. Wagadu 1. Retrieved from http://webhost1.cortland.edu/wp-content/ uploads/2014/02/miraftab.pdf

OECD-UNDESA. (2013). World migration in figures. Retrieved from http://www.oecd.org/els/mig/WorldMigration-in-Figures.pdf

Pécoud, A. (2015). Depoliticising migration: Global governance and international migration narratives. London: Palgrave Macmillan.

Pereira, C. (1979). Gramsci: Estado y sociedad civil. Cuadernos Políticos, 21, 66-74.

Piper, N. (2016). Make migration a choice not a necessity: Challenging the instrumentalisation of migration as a tool for development. In J. Grugel \& D. Hammett (Eds.), The palgrave handbook of international development (pp. 365-379). London: Palgrave Macmillan.

Portes, A. (2009). Migration and development: Reconciling opposite views. Ethnic and Racial Studies, 32, 5-22.

Rother, S. (2018). The global forum on migration and development as a venue of state socialisation: A stepping stone for multi-level migration governance? Journal of Ethnic and Migration Studies. doi:10.1080/1369183X. 2018.1441605

Santos, B. de S. (2005). The future of the world social forum: The work of translation. Development, 48 (2), $15-22$.

Southern Poverty Law Center. (2007). Close to slavery: Guestworker programs in the United States. Montgomery, AL: Southern Poverty Law Center.

Swing, W. L. (2015). Migration in a world in disarray. Geneva: IOM.

United Nations. (2017a). Trends in international migrant stock: The 2017 revision. Department of Economic and Social Affairs. Population Division. (United Nations database, POP/DB/MIG/Stock/Rev.2017).

United Nations. (2017b). Making migration work for all. Report of the Secretary-General 12 December 2017. Retrieved from https://reliefweb.int/sites/reliefweb.int/files/resources/N1743962.pdf

United Nations Conference on Trade and Liberalization. (2010). World investment report 2010. New York, NY: Author.

UNHCR. (2015). Global trends. Forced displacement in 2015. Geneva: Author.

Van der Pijl, K. (1984). The making of an Atlantic ruling class. London: Verso.

World Bank. (2017). World Bank national accounts data, and OECD National Accounts data files. Retrieved from https://data.worldbank.org/indicator/NY.GDP.MKTP.CD

World Social Forum. (2001). Charter of principles. Retrieved from https://www.colorado.edu/AmStudies/lewis/ ecology/wsfcharter.pdf 


\title{
Global migration governance, civil society and the paradoxes of sustainability
}

\author{
Branka Likić-Brborić
}

\begin{abstract}
Against the presentation of an asymmetric global governance, this article analyzes the formation of global migration governance with its focus on the politics of migration and development. It traces the marginalization of a rights-based approach to migration and the streamlining of migration governance into business-friendly migration management and a geopolitical securitization agenda. It also reviews the trajectory towards factoring migration into a global development policy discourse as formulated in the UN 2030 Development Agenda. Specifically, it indicates that the inclusion of migration into the Sustainable Development Goals (SDGs) may promote migrant workers' rights because several of these invoke universal human rights instruments, social protection and the observance of the ILO decent work agenda. However, this will only be possible if civil society critically engages powerful state and non-state actors in the process of monitoring the SDGs' implementation, and resists their streamlining into investment and free trade neoliberal development regimes.
\end{abstract}

\section{Introduction}

International migration has come to be an essential component of neoliberal globalization and its related national and regional political economies of inequality (Ackerman, Goodwin, Dougherty, \& Gallagher, 2000; Milanovic, 2018). On the one hand, it has become one of the vital survival strategies for people struck by wars, poverty and precarity, brought about by vagaries of neoliberal geopolitical and geo-economic restructuring, and the landscaping of free trade and free capital movement. On the other hand, international migration has been projected as a solution to demographic deficits in the global North. Concurrently, there is a dominant view which sees international migration as the source of enormous gains to be unleashed by free labour migration from poorer to economically dominant countries. Arguably, this can by far outscore the effects of global trade and finance on poverty reduction (Pritchett, 2006; Rodrik, 2011).

The majority of the 244 million international migrants are migrant workers. ${ }^{1}$ Labour migrants, both regular and irregular, have become targets for the configuration of a (less free) global labour market regime, subjected to a regime of asymmetric global governance driven by the supremacy of a free trade regime and the canon of the free movement of capital (Likić-Brborić \& Schierup,

This is an Open Access article distributed under the terms of the Creative Commons Attribution-NonCommercial-NoDerivatives License (http:// creativecommons.org/licenses/by-nc-nd/4.0/), which permits non-commercial re-use, distribution, and reproduction in any medium, provided the original work is properly cited, and is not altered, transformed, or built upon in any way. 
2015). The current global political economy features labour commodification, as well as the disassembling of labour and social rights. It produces uneven patterns of exploitation and precarious employment, with migrants constituting the most vulnerable segment in the making of a flexible and disposable labour force (Woolfson \& Likic-Brboric, 2008). Yet, for better or worse, there is no unified international migration regime, comparable to financial and trade regimes, which regulate the free movement of capital, goods and services in a globalized political economy (Betts, 2011; Koser, 2010). The persistence of irregular migration flows and the 'refugee crisis' in 2015, instigated by the war in Syria and protracted conflicts in the Middle East and Africa, demonstrated a flagrant lack of a functioning regime of the international movement of people, encompassing shared rules, norms and procedures, as well as authoritative actors accountable for its implementation.

Although there is no coherent global governance regime for migration, we have seen multiple regional and global initiatives and deliberations on global migration governance. Within an asymmetric and dual global governance, the dominant governance actors, such as transnational corporations (TNCs), the World Trade Organization (WTO), the World Bank (WB) and developed states, have sought to promote a business-friendly migration management approach, driven by the demand of matching high- and low-skilled labour, without entertaining labour and migrants' rights. Conversely, several UN agencies led by the International Labour Organization (ILO) challenged this approach by launching a rights-based approach to migration (ILO, 2006). This approach was supported by a multitude of 'old' and 'new' social movements (Munck, 2007) that mobilized for social justice in a global political economy, and contested the increasing power of corporations and financial institutions shaping the hegemonic governance of production, finance, security and technological innovation.

Following several international initiatives, conferences and reports (GCIM, 2005; WCSDG, 2004), the UN initiated a High-Level Dialogue (UN-HLD) on International Migration and Development in order to address migration challenges. The first UN-HLD was held in 2006, yet failed to include migration on the UN norm-setting agenda. Subsequently, in 2007, governments launched the Global Forum for Migration and Development (GFMD), designed as a state-led, nonbinding and informal process. It is considered as the most inclusive arena for framing the incipient global governance of migration, involving continuous intergovernmental deliberations between sending, receiving and transit states (Betts, 2011). Since the inception of the GFMD, so-called 'Civil Society Days' (CSD) have been organized preceding the GFMD meetings. The GFMD/CSD process mirrors a common feature of global governance processes, informed by the so called Post Washington Consensus (PWC); the reframing of neoliberal development policies of comprehensive marketization, trade liberalization and privatization in terms of a discourse of sustainability, participation and 'good governance' (Smith, 2012; Stiglitz, 2002). In this conjuncture, the CSOs, including various labour and migrant rights movements and activists have managed to mobilize and strategically engage for the promotion of a rights-based migration governance, demonstrating genuine transversal cosmopolitanism (Hosseini, Gills, \& Goodman, 2017) and tenacious activism, in spite of rather limited access to the migration agenda-making arenas and the democratic deficit in global governance (Grugel \& Piper, 2011; Schierup, Ålund, \& Likić-Brborić, 2015). Informed and strengthened by the World Social Forum for Migration (WSFM) and the vision of 'another world is possible', major civil society associations and networks have mobilized for the inclusion of the migrants' rights into the UN-HLD and the GFMD agenda. Migrants Rights International (MRI), the Migrant Forum for Asia (MFA), the Europe-based Platform for International Cooperation on Undocumented Migrants (PICUM) and the Transnational Migrant Platform (TMP), to name a few, initiated the People's Global Action for Migration, Development and Human Rights (PGA). It was set as a parallel event to the 
GFMD/CSD process and an alternative space for migrant rights organizations, trade unions, academia, faith-based organizations, as well as women and human rights organizations to strategize for the promotion of migrants' human rights and Southern perspectives on migration and development (Castles, 2011; MFA, 2009).

The very denomination of these processes is telling of their ambition - to connect 'migration and development' (Omelaniuk, 2012). This was finally attained in 2015 by factoring migration into the UN Post-2015 Development Agenda and a number of sustainable development goals (SDGs). At the GFMD/CSD meeting which took place in Istanbul in October 2015, several leading migrant and migrant-supporting CSOs announced this as a major breakthrough. Since its adoption in September 2015, the UN 2030 Development Agenda, advertised as an integrated approach to development, inclusive of human and labour rights for all, has promised its realization in terms of governance that assures accountability for the promotion of transnational social rights and citizenship. This promise needs to be scrutinized, which this article attempts to do.

Against the background of the contextualization and presentation of an asymmetric global governance, understood as instrumental for neoliberal globalization, this article analyzes the process through which global migration governance has been formulated with its focus on the politics of migration and development. Furthermore, it scrutinizes the trajectory towards factoring migration into a global development policy discourse as formulated in the UN 2030 Development Agenda and SDGs. The main ambition is to identify the space for and the role of global civil society in this process, as well as its organizational capacity and strategies to challenge a de-politicizing 'neoliberal political rationality' through projecting counterhegemonic political visions, alternative development models and a rights-based approach to migration.

The main question addressed is the following: What has happened with the alternative approaches to development and a rights-based approach to migration in an ongoing reframing of the migration-development nexus in terms of the neoliberal approach to development focused on business-friendly migration management and temporary, circular migration schemes? In the following, the article maps the global institutional and organizational actors and frameworks which shape the GFMD/CSD process, its normative positionality and operational modalities, including relations with governments, the UN system and civil society. It endeavours to identify some of the main actors and alternative discursive frames as articulated through the GFMD process and interrogate what agenda-setting, streamlined towards migration management and the migration related SDGs, may mean for the space and role of civil society.

\section{Global political economy, migration and global governance}

Globalization, informed by the neoliberal vision of free-market capitalism, has involved the configuration of the global economy by the asymmetric incorporation of countries, territories and people into a crisis-driven expansion of neoliberal order across the world. The emerging 'variegated' neoliberalization, imposing persistent and uneven 'market-disciplinary regulatory restructuring', has entailed the privatizations of state owned enterprises and public services, as well as austere fiscal policy and trade liberalization, perpetuating neoliberal transformation dynamics across time and space (Brenner, Peck, \& Theodore, 2010). Particularly, neoliberal globalization has involved the global financialization of economies, corporate-driven transnational reorganization of production via global production networks (GPN) and global value chains (GVC), outsourcing and subcontracting, deepening commodification, and the 'tendential' configuration of a global labour market (Overbeek, 2002). 
A 'moving map of neoliberalization' (Harvey, 2005), carved out through financial and corporate global and regional restructuring, has generated economic crises, unemployment, poverty, the informalization of the economy and irregular migration, resulting in the interlinking configurations of political economies of inequalities and the precarization of life and work both in the developing and developed world (Schierup \& Jørgensen, 2016). Globalization has challenged the nation state and instigated the crisis of multilateralism, as well as the inclusion of corporate interests and conservative NGOs, pushing for further reforms of the UN multilateral development system towards a 'new constitutionalism' of the WTO (Fitzpatrick, 2009). Responses to poverty, increasing inequality, the informalization of the economy and the resulting irregular migration have projected development policies informed by the PWC and 'Bretton Woods paradigm', regarding investment friendly market reforms, the privatizations of public services and a GATT/WTO-driven international trade regime.

In this context, Phillips (2009) claims that 'the articulation of migration as a national development strategy is representative of a transnationalized (and regionalized) form of uneven and unequal development'. It is one dynamic motor generating 'inequalities between national economies and societies which result from the often massive export - and absorption - of workers from the capital-poor areas of the global "periphery"' (p. 133). The government policy shift towards facilitating and outsourcing governance, attuned to the support and maintenance of the corporate practices constructing global production networks and global value chains, has sustained the 'adverse incorporation' of informal, often forced labour into the formal economy (Mayer \& Phillips, 2017).

The resulting 'hollowing out' of national labour market regulations and the related changes of industrial relations, inferred by the connective informalization of the economies and irregular migration, demonstrated an urgent need for a transnational governance of workers' rights (Egels-Zandén, 2009). Several UN agencies over the course of the 1990s, within their overlapping mandates to promote human development, labour rights and social justice, elaborated on a comprehensive theoretical and policy framework for the promotion of the social dimension of globalization; a 'UN paradigm' that could represent an alternative to neoliberal trade and export-led development approach (Likić-Brborić \& Schierup, 2015; Thérien, 2005). The ILO, in line with its mission of labour decommodification, took a leading role in forging a discourse of global justice, solidarity and fair globalization, configured around the concept of decent work and a rights-based migration approach. On the highest level, the ILO initiated the WCSDG (The World Commission on the Social Dimension of Globalisation), producing its final report 'A Fair Globalisation' in 2004. The report takes stock on the impact of globalization and proposes an inclusive framework for a fair global governance in order to balance global financial and economic institutions, free capital and trade flows, with a universal social floor, human and labour rights, and fair rules for the cross-border movement of people (WCSDG, 2004). It also points to the lack of 'a multilateral regime for the cross-border movement of people that makes the process more orderly and eliminates the exploitation of migrants' (p. 96), which reinforces different initiatives to develop global governance for migration. The UN Secretary-General launched the Global Commission on International Migration that presented its report in 2005 (GCIM, 2005), calling for migration policies to curb undocumented migration and reaffirm existing legal mechanisms that should frame migration policies. However, the ensuing process of political deliberations on and the policy production of migration governance has taken a turn that reinforced WTO/WB/IMF-centred 'facilitating' and 'outsourcing' global governance, as well as involve the further marginalization of the ILO as described in the next section. 


\section{Towards global migration governance}

According to Betts (2011), the institutional framework for regulating global migration consists of a weak formal multilateralism, 'embeddedness' into other transnational rules and regulations, such as trade regimes, and various informal networks and partnerships. As international migration is 'regulated through a multilayered architecture of international governance', comprising binding transnational rules and regulations, but also a variety of 'soft law' procedures fragmented across different governance levels (Kunz, Levenex, \& Pannizon, 2011, pp. 15-16), it has proved too complex and dysfunctional in addressing contemporary migration challenges. The complexity involves both different types of migration and their assignment to corresponding fields of international law at different governance levels.

Drawing on the understanding of 'global' as overlapping scales, Gamlen and Marsh (2011, p. xiv) state 'that global migration governance is not simply synonymous with the international system, but is instead intertwined with and constituted by processes involving multiple geographical scales including an emergent transnational scale'. They identify three different modes of governing global migration. The first is the national mode as the nation-state is still the most important regulator by means of controlling migration through borders, safeguarding access to territory, nation, citizenship and rights. The second is the international mode that entails the formal and informal cooperation between nation states to regulate migration issues. It includes bilateral, regional and multilateral governance. They also identify a new transnational mode of migration governance as 'a neoliberal assessment of the role of states in regulating market mechanisms such as migration' (2011, p. xxiv). Informed by 'the new migration and development optimism', this approach promotes temporary and circular labour migration schemes allegedly producing 'triple wins' for sending and receiving states, as well as the migrants themselves, connecting diaspora engagement to development in their homelands (2011, p. xxiv). This mode of governance pursues market solutions and, in line with neoliberal governmentality, constitutes mobile, circulating transnational subjects in the globalized economy beyond the purview of nation-states.

Kunz et al. (2011) identify four main interrelated migration issues regulated at multilateral, transregional and bilateral levels, namely: economic mobility, security, the human and labour rights of migrants, and development cooperation. Within this architecture, the rights of refugees and workers stand out as the most regulated in terms of codification and organizational responsibility for the implementation. The refugee regime, overseen by the UN High Commissioner for Refugees (UNHCR), is regulated by binding international laws. ${ }^{2}$ It is still a stronghold of refugee protection, in spite of challenges brought about by various states' non-compliance in cases of sundry refugee emergencies. Yet, other human and workers' rights in the global economy have been poorly protected. Even though there is a bundle of human rights and labour conventions, they lack a supporting institutional structure (Aleinikoff, 2003). Others, like Kunz et al. (2011), claim in line with Betts (2011) that there is an institutional structure, but it is weak and fragmented.

Historically, the responsibility for labour migration was divided between the ILO and the International Organization for Migration (IOM). The former was established in 1919 and later positioned within the UN system. Its mission has been to set norms assuring the decommodification of labour in the international economy, including the protection of migrant workers. To that end, several ILO conventions have been adopted. ${ }^{3}$ However, neither the USA nor Canada have signed or ratified them, in spite of an ILO strategy to conform to US hegemony and its flexible labour market regulations (Cox, 1977; Vosko, 2002). Due to US anti-communism in the Cold-War era following WWII, the role of the ILO, especially in the field of labour migration, has been side-lined. However, after the 
exclusion of social clauses from the WTO trade agreements and Dispute Settlement Mechanisms in 1996, the ILO attempted to assume the main responsibility for connecting labour migration to universal labour standards and rights. It formulated and promoted the Decent Work Agenda (DWA) and a rights-based approach to migration that also includes the 1990 UN Convention on the Protection of the Rights of All Migrant Workers and Members of their Families (ILO, 2010; Likić-Brborić \& Schierup, 2015). However, the ILO's role in the global governance of labour migration remains weak.

Contrastingly, the IOM has been gaining a central role in the development of global migration governance. Instead of conforming to UN-based ILO and UNHCR normative and organizational missions, the Western receiving countries decided to establish the Intergovernmental Committee on European Migration in 1951, outside the UN system, which was later renamed the IOM (Georgi, 2010). Its main mission was initially to assist receiving states in the admission of European migrants after WWII, and later to manage East-West and other refugee crises, both during and after the Cold War, not to protect migrants. Being an intergovernmental organization, it is supported by $166 \mathrm{mem}-$ ber states and 11 state observers, as well as a number of NGOs and INGOs, and is structured according to a project-based model operating in 150 states across the globe (Martin, 2015; Pécoud, 2018). The IOM has been praised for its efficiency and flexibility in supporting governments to meet various migration challenges and needs. In comparison to the UN-based ILO and UNHCR, upholding UN human and labour rights conventions, the IOM has been normatively unrestricted and flexible to assist states to 'manage migration' by both controlling irregular and facilitating labour migration (Pécoud, 2018). It is regarded as the key actor that generates consensus informed by a global approach to migration, including border management measures and a problematic policy of 'voluntary return'. Last but not least, informed by neoliberal ideas of migration as individual solutions to inequality and poverty brought about by the impact of globalization, it has been instrumental in adjusting national migration policy-making to the needs of global capitalism and supporting private recruitment practices (Pécoud, 2018).

Drawing on Geiger and Pécoud (2014) and Kunz et al. (2011), it is possible to identify the constitution of three different categories of migrants to be assigned to different international organizations: (1) migrant workers, whose rights are monitored by the ILO and Office of the UN High Commissioner for Human Rights (OHCHR); (2) refugees and asylum seekers to be protected by the UNHCR; and (3) 'economic migrants', who are mostly circular mobile workers responsive to transnational labour market and corporate demand, to be expedited by the IOM. The term 'economic migrants' has also been used in media and policy discourses to differentiate those who migrate in search of a better life from refugees, which also implies that they do not qualify for asylum. ${ }^{4}$ It is the last category, economic migrants and the need to govern new economic mobility has instigated various transnational and trans-regional initiatives to develop the global governance of migration. Susan Martin (2015, p. 66) openly states that '(m)ultilateral corporations want governments to facilitate intercountry movements of their own personnel' and need to meet labour shortages in several sectors, such as agriculture, IT or health.

While labour mobility is partly regulated by the WTO/GATS (World Trade Organization/General Agreement in Trade in Services) on a multilateral level, it has not included the protection of labour and human rights. There is also a plethora of various regional and bilateral trade agreements that address labour mobility. ${ }^{5}$ These are complemented by corporate voluntary codes of conduct and international framework agreements (IFAs) struck between global unions and multinational corporations, reflecting a long-term shift from government to the weak transnational governance of labour rights. 


\section{Towards a neoliberal migration regime: the IOM and migration management}

In search of developing transnational solutions to the twin problem of irregular migration and economically wanted trans-regional and global migration, several initiatives have been put forward, such as sub-regional and regional consultations processes (RCPs), inter-regional fora (IRF) and global discussions on common norms and regulations for a global migration policy. The landmark in the inclusion of migration into UN development fora is the 1994 International Conference on Population and Development (ICPD) in Cairo. At this meeting, 179 governments agreed on a 20-year comprehensive Programme of Action (PoA), a set of internationally agreed recommendations on both internal and international migration, with a specific section 'International Migration and Development'. It is important to emphasize that the main recommendation to governments was to focus on the root causes of migration, development and the right not to migrate (Martin, 2015).

The idea to link migration to development was revisited by the Swiss government, which presented the Berne Initiative in 2001, a state-led consultative process, to engender a cooperative approach to effective international migration management. As a result, in December 2004, a non-binding reference framework, the 'International Agenda for Migration Management' (IAMM) was presented, focusing on the need to develop shared understandings and 'effective practices' to promote legal migration and integration pathways for immigrants, but also to cut irregular migration and fight human trafficking. The Agenda also projected the links between migration and development, security and other international concerns (Martin, 2015, p. 72). In this, the IAMM departs from the ICPD PoA progressive development approach and narrows it down towards the nexus between migration and development attuned to the interests of the receiving developed states.

Susan Martin (2015) maintains that the Berne Initiative, although successful in bringing governments together, needed to be legitimized by forging more inclusive forms of collaboration with nonstate actors. The other issue was to identify UN and other international agencies dealing with migration issues, and propose a main agency with a clear mandate to manage migration challenges, as emphasized by the so-called Doyle Report, commissioned by UN Secretary-General Kofi Annan. The report asked for a clear organizational mandate to manage migration issues, and to that end, the Secretary-General appointed the GCIM, financed by Sweden and Switzerland as the main actors behind the Berne Initiative. Once again, the problem of organizational responsibility for migration issues came to the fore, and the commission opted for merging the IOM and UNHCR, or the inclusion of the IOM into the UN system in order to regulate voluntary migration. Interestingly enough, the potential role of the ILO was downplayed. Without making a final recommendation, the Global Migration Group (GMG) was built, consisting of the original members of the Geneva Migration Group (IOM, ILO, OHCR, UNCTAD, UNHCR and UNODC), the WB and other agencies $^{6}$ (Martin, 2015).

In the following years, the IOM assumed the main position, producing knowledge and framing the discourse of migration as a 'global' problem implying 'global' cooperation, but also as 'a normal process' bringing 'triple-win' benefits 'to All' (migrants, as well as sending and receiving countries). Migration was to be 'well managed' and 'orderly', as well as linked to development and environmental issues (Geiger \& Pécoud, 2014; Pécoud, 2018). This discourse frames the main political focus on: security and border control; economic migration adjusted to labour market demand; and the protection of migrants and development (Pécoud, 2018). Drawing on the Foucauldian perspective on liberal government, which focuses on technocratic power to manage populations, Sara 
Kalm (2010, p. 29) sees global migration management as 'a particular solution to the question of how to govern the global population'. It reflects the 'political rationality' of neoliberal governmentality to infuse marketization and entrepreneurialism on both institutional and individual actors, constituting 'mobile subjects' in a technical and non-political manner. At the same time, she demonstrates how the global policy discourse normalizes migration and emphasizes its potential positive impact on the global political economy.

In their critical examination of the emerging migration management policy approach, Geiger and Pécoud (2010) state that this depoliticized and technical discourse of migration resonates with the PWC; neoliberal policy prescriptions jointly designed by the WB and IMF and imposed on crisisridden indebted developing countries as conditions for their debt restructuring. However, this policy approach, supported by Western receiving countries, needs to be diffused to other sending and transit countries, and legitimized in line with the PWC participatory governance model via consultations with other stakeholders and civil society actors.

\section{UN-HLD, GFMD/CSD and the business case for migration and development}

Following these initiatives and demands for a coherent global migration regime supporting international migration, the UN-HLD was launched in 2006. Instead of focusing on the right not to migrate, the UNHLD promoted a new direction, attuned to the idea of employer- and trade-friendly transnational economic migration, facilitating a WTO/GATS mode of global migration governance. This is not surprising considering the fact that the UN Secretary-General appointed Peter Sutherland, former director general of the WTO, previous EU commissioner for competition, as well as a chairman of BP and Goldman Sachs, as his special representative for international migration and development. Besides the representatives of states and GMG agencies, various CSOs, NGOs and business stakeholders participated. CSOs also established a global steering committee that staged a parallel event, the Global Community Dialogue on Migration, Development and Human Rights. With 80 participants representing 45 organizations from Asia, North America, Latin America, Europe, Africa and the Pacific, the group demanded guarantees for migrant workers' labour rights and advocated for a rights-based approach to migration (MFA, 2009).

In spite of the initiative to discuss international migration as a norm-setting issue within the UN framework, the outcome of the HLD was to continue the interstate dialogue informally, leading to the launch of the Global Forum for Migration and Development (GFMD) in 2007. Since then, within an asymmetric multi-level global governance, the GFMD, as an 'informal, non-binding, voluntary and government-led process' figures as the most comprehensive arena for continuous intergovernmental deliberations between sending, receiving and transit states in order 'to foster practical and action-oriented outcomes at national, bilateral and international level' and 'maximize the development benefits of migration and migration flows' ${ }^{7}$

The GFMD has been held every year, except for 2013, taking place interchangeably in developing and developed states, which also chair the respective GFMD meetings. The host states responsible for previous, present and coming meetings build the so-called Troika, which prepares the meetings, with support of the Steering Group (SG) consisting of supporting governments responsible for the formulation of Roundtable (RT) agendas. The UN Special Representative also attends the meetings, while all other states are invited to join the meetings of 'Friends of Forum', together with UN agencies and other selected organizations. ${ }^{8}$

From the beginning, the GFMD also designated so-called Civil Society Days (CSD) as spaces to exchange ideas with a plethora of international organizations, multilateral global and regional bodies 
(e.g. GMG), business actors, and broad civil society, including migrant organizations, trade unions, academia and non-governmental think-tanks. By designing the CSD, the Forum aimed to address the deficiency of the Berne Initiative to meet the criteria of inclusiveness and obtain legitimacy. It initially supported a space for a larger social movement, which later denominated as the People Global Action for Migration, Development and Human Rights (PGA), to hold gatherings preceding and preparing for the CSD. Since 2010, it has also designated the so-called 'Common Space' for Civil Society to interact with the governments.

The Troika governments set the agenda for the GFMD meetings, as well as the initial blueprint for the CSD meetings. The superficial scrutiny of the main themes of the government agenda towards the inclusion of migration into the SDGs barely traces any influence of migrants and for migrants' CSOs on the GFMD process. The first GFMD meeting in Brussels, with the theme 'Migration and Socio-Economic Development' focused on labour mobility, remittances, policy and partnerships and apparently disregarded migrants as actors. Only two of the meetings focused on migrants as actors in their main themes. ${ }^{9}$ However, migrants' empowerment and human development are justified only if they serve development. Particularly, in the overall summit themes, ${ }^{10}$ migrants as actors have dissolved into discourses centred on 'migration' and 'development', 'partnership' and 'cooperation', and the instrumentalization of migration for the 'benefits for all', clearly reflecting the IOM discourse of migration management.

In their review of the intergovernmental recommendations and conclusions on migration governance initiatives from 1994 to 2009, Maas and Koser (2010) confirm that most recommendations concern governance and cooperation, while the issues of root causes, labour migration, social cohesion and circular migration were not adequately attended. Furthermore, they find that the 2007-2009 GFMD recommendations were far less focused on the issues of human rights, protection and gender, and the GFMD was called to ensure 'meaningful consultation with the private sector in particular and with civil society at large in general' (p. 11).

The report, commissioned by the Hague Process on Refugees and Migration (THP), ${ }^{11}$ was written by Wies Maas from the International Catholic Migration Commission (ICMC) and Khalid Koser from the World Economic Forum (WEF) Global Agenda Council on Migration. It seems that the report set the stage for the mobilization of both business stakeholders and CSOs advocating for migrants' human and labour rights before the 2010 GFMD in Mexico. The organizers responded by creating a Common Space for enhanced interchange between CSOs and governments, and by handing over the organization of the 2011 CSD to civil society, namely the ICMC.

When it comes to business stakeholders, their influence on the GFMD process has considerably grown. In 2011, the Swiss chair focused on labour migration and decided to involve the private sector, business leaders and recruitment agencies, in line with the final statement of the CSD in Mexico. This was even reflected in the CSD meeting in Geneva, marked by WEF and THP active involvement in setting up the theme on labour matching. The charm offensive of the 'private sector' continued ahead of the 2013 HLD in New York with the submission of the White paper for the United Nations General Assembly High Level Dialogue on International Migration and Development 2013. The paper, written and signed by, besides Khalid Koser, the WEF Global Agenda Council on Migration, Ola Henrikson, the director-general, Ministry of Justice, Sweden, Göran Hultin, chairman and chief executive officer of Caden Corporation, the UK, and not least by a critical scholar Saskia Sassen, presents a business case for migration, development and integration, and pledges the full respect for the human rights of migrants.

The Swedish chair in Office, which took over in 2013/14, unmistakably pursued an employerfriendly labour migration approach, informed by the 2008 Swedish labour migration law as 'the 
best practice'. This is not surprising considering that the Swedish conservative government set in place radical reforms of the Swedish welfare model and labour market institutions in an attempt to weaken Swedish trade unions which were reluctant to participation in the GFMD in Stockholm. In 2015, during the GFMD meeting in Istanbul, the so-called 'business mechanism' was introduced, assuring agenda-setting power for business stakeholders. In the midst of the refugee crisis, the 2014-2015 Final Concept Note ${ }^{12}$ stated that: 'A policy framework conducive to safe, fair, orderly, well-governed and productive migration, that is respectful of the human rights and dignity of every human being, is a prerequisite for realizing the full developmental potential of international migration' (p. 1). However, while reaffirming the inclusion of migration into the 2030 Sustainable Development Agenda, it called for 'sector-specific development policies', the recognition of the demand for low-skilled labour in agriculture and care work, and the need to protect these migrants. Finally, yet importantly, the concept paper also launched a 'developmental approach' to the problems of refugees and forced migrants, claiming 'the traditional "care and maintenance" model ... unsustainable' (p. 5) and advertising labour market access via recruitment companies as a winning solution to the challenges brought about by the refugee crisis. Thus, in spite of the declared respect for human rights, this developmental approach exemplifies a neoliberal reframing of the solution to the 'refugee crisis' by repositioning refugees from the protection assured by a binding international refugee regime into weakly protected economic migrants, absorbed into temporary and circular labour migration regimes, and by outsourcing their management to private recruitment companies.

François Crépeau, in his capacity of the United Nations Special Rapporteur on the Human Rights of Migrants, warns that these trajectories 'pose fundamental ethical and legal questions about how the programmed temporary nature of mobility and the economic rationale can be reconciled with the human rights of migrants' and calls for 'a human rights-centred global governance' (Crépeau \& Atak, 2016, p. 124). Regardless of this critical note, and the loss of legitimacy in the 2008 financial crisis, the neoliberal project seems to relentlessly progress so that one more 'refugee crisis' does not 'go to waste' (cf. Mirowski, 2013).

The 2016 GFMD/CSD proceeded towards the further designation of a migration management approach in order to fit the corporate global workforce and people management, as illustrated by the excerpt from the concept paper (p. 2): ${ }^{13}$

Meanwhile, fast emerging global trade-investment-finance regimes and new forms of regional connectivity frameworks demand that 'people' are placed at the centre of economic planning equations and that peoples' movement (people-to-people contact) be facilitated to a much greater extent than in the past if ambitions for 'inclusive economic growth' are to be fully realized.

Simultaneously, the issues of migrant and human rights shifted to the 2016 New York Declaration for Refugees and Migrants, and the UN negotiations for the global compact for safe, orderly and regular migration (GCM).

In this trajectory towards business-friendly migration management and the legitimation of the commercialization of international migration, the German chair of the GFMD summit in Berlin referred to a 'global social contract' in the 2017-18 GFMD Concept Note 'Towards a Global Social Contract on Migration and Development'. This needs to be deconstructed as it reflects the political vision of the 2030 Sustainable Development Agenda, which has been, paradoxically, included in the discourse of the WEF. At the 2018 WEF Annual meeting, Sharan Burrow, general secretary of the International Trade Union Confederation (ITUC), reiterated the need for a new social contract and called for 'the responsibility of business, including platform businesses', especially as: 
... corporations refuse to practice due diligence, by not establishing grievance mechanisms for remedy of abuses against the hidden $94 \%$ of their workforce in their global supply chains, they perpetuate a depraved model of profit-making that has driven inequality to a level now seen as a global risk in itself. ${ }^{14}$

However, her critique seems to have been instrumentalized by WEF Chairman Klaus Schwab to launch the idea of a new social contract and the central role of business in pursuing this goal, while 'government and civil society must be fully engaged partners in a truly multistakeholder effort' ${ }^{15}$ This business-led global governance can also be interpreted as a corporate/business appropriation of the 2030 Agenda and its implementation via public-private partnerships, such as Multisectoral Global Funds (MGF).

At this stage, we have consequently seen how the processes of global migration governance framing have been streamlined into a GFMD-driven management approach. Instead of the forging, institutionalization and implementation structures of accountability for realization of human and labour rights, these rights and regulations have been transferred to voluntary modes of corporate governance, although dressed in the human rights and fair migration discourse. The shift to bilateral and regional free trade agreements and partnerships translates GATS Mode 4 into lower levels of governance. The recent designation of the IOM as the UN Migration Agency legitimizes the business friendly migration regime, reinforced by the inception of the WEF's vision of migration governance that merges techniques of securitization and economic mobility.

In the course of a decade long process, the engagement and influence of civil society have faced multiple constraints. Although, since 2011, the role of the GFMD Civil Society Coordinating Office has been assigned to the ICMC; an international non-governmental organization based in Geneva, previously chairing CSD Steering Committee. However, this repositioning has led to internal political divisions. The same year, several GFMD critical organizations, including trade unions and migrant women associations, initiated the building of the Global Coalition for Migration (GCM), a 'meta network' with the objective of meeting the challenge of internal rifts (Kalm \& Uhlin, 2015) by reaffirming migrant workers and human rights perspectives. The ICMC, on the other hand, pursuing the aim of factoring migration into the 2030 Sustainable Development Agenda, built the Migration and Development Network (MADE), inclusive of business-friendly diaspora and development NGOs. It also reshuffled the CSD Steering Committee in order to marginalize CSOs critical of the GFMD. In the process, the PGA/WSFM as an 'invented space' (see Rother, 2018b; Ålund \& Schierup, 2018; Delgado Wise, 2018) has shrunk, reflecting the problems of the marginalization and lack of institutional and financial support, shared by many social movements. This confirms previous studies that have shown limited access to and influence of civil society on global governance and the practices of 'civic-consensual modes of relation to the global political economy' (Buckley, 2013, p. 65; O’Brien, Goetz, Scholte, \& Williams, 2000).

While Stefan Rother (2018a) sees the discursive framing of migration issues in terms of human rights in the GFMD/CSD process, and the IOM projects as 'norm diffusion and state socialisation', this evolvement needs to be assessed against the marginalization of ILO rights-based labour migration governance. Even the ILO has been marginalized and remains a thin project-based organization balancing between levels and agendas, in spite of the fact that 'decent work agenda' has been stated as an important SDG.

\section{Migration governance, development and paradoxes of sustainability}

The inclusion of migration into the 2030 Sustainable Development Agenda is attributed to CSOs' mobilization, as well as their organizational capacity to lobby for the inclusion of migration and 
migrants' human and labour rights into global development strategies. Particularly, the formulation and promotion of a joint civil society platform on migrant and migration-related goals and targets for development, the so-called 'Stockholm Agenda' that was launched at 2014 GFMD/CSD, is considered the most significant stage in this process.

The 2030 Agenda declares to offer an integrated development approach, which has managed to balance opposing social, economic and environmental considerations, the so-called 'triple bottom line' (Sachs, 2012). This promise was translated into 17 SDGs and 169 targets, and 11 of these goals are relevant for migration. ${ }^{16}$ The High Level Political Forum (HLPF) as 'the central platform for the follow-up and review' of the implementation process, involving both states and stakeholders including CSOs, has been established. Furthermore, its indivisibility is allegedly ensured by inclusive and participatory 'good governance' to be achieved by stakeholders' participation in the review, follow-up and monitoring of the 17 SDGs. However, all this ambition is conditional on the financial sector's support, as pledged by the Addis Ababa Action Agenda at the Third International Conference on Financing for Development in 2015.

Seen in this perspective, it is important to review if the new governance for development in general, and the governance of migration in particular, announced in the SDGs will indeed address the root causes of the precarization of life and work brought about by the decades of top-down implementation of uniform neoliberal development policies and their technical implementation. The WTO norms and standards remain unchallenged, at least in the global fora, with the Bretton Woods international financial institutions (IFIs), namely the World Bank and the IMF, still instrumental in the imposition of the neoliberal development model and the promotion of free capital mobility. Civil society actors have criticized the exclusive and technical approach to developing indicators that measure the realization of the goals and targets. It seems that the UN organizational architecture, attuned to the implementation of the SDGs through the establishment of the HLPF, is contingent on the mandate and required resources to promote hierarchical global economic governance.

Considering the hegemonic consensus behind 'migration management', reflected in recurrent initiatives to devise optimistic regional and bilateral labour migration schemes, such as temporary/circular migration, which are expected to bring forth developmental benefits for poor countries in line with a so-called triple win and 3R (Recruitment-Remittances-Return) approach to the migration/development nexus (Martin, Martin, \& Weil, 2006), it is questionable if a comprehensive rights-based regime for labour and economic migration can be institutionalized through projectbased instances. The ILO has received a supportive role by the promotion of a Fair Migration and Fair Recruitment Practices Project and the MFA has joined as a project partner. The IOM has, on the other hand, engaged a prominent MRI/PGA activist as an adviser. These practices of marginalization and co-option clearly call for addressing the past and future role of, space for and organizational capacity of CSOs in agenda-setting and implementation processes. So far, the engagement of CSOs in various global processes has been captured into the promotion of the neoliberal development project 'through the routinising of neoliberal processes of "participation", transparency and accountability' (Carroll \& Jarvis, 2015, p. 277). This resonates with David Harvey's warning of the danger of human rights activism becoming embedded in the neoliberal frame (Harvey, 2005, p. 176).

Essentially, such a discussion brings to the fore the need for a serious interrogation of the potential of global civil society to resist the persistent neoliberal globalization and engrained free trade ideology which are undemocratically pushed for by the WTO/WB/IMF and on-going, top-level covert negotiations on regional trade agreements. Yet, the continuation of the GFMD process in parallel to HLPF review of the 2030 Agenda needs to be scrutinized by the CSOs in order to assure the 
genuinely integrated nature of the SDGs in promoting democratic governance, alternative and local development models (see McKeon, 2018) that entertain labour rights, as well as social and health protection for all. If not, the SDGs might easily become the instruments of the final marketization and corporatization of human life.

Furthermore, 'the hegemony of progressive neoliberalism' and its progressive politics of recognition, has enabled 'a deeply regressive political economy to become the dynamic center of a new hegemonic bloc' (Fraser, 2017), ushering populist and xenophobic political responses to forced migration. Following the 2008 financial crisis and the 2015 European 'refugee crisis', we have seen the populist and nationalist capture of traditionally democratic states, increasing xenophobia and anti-migrant attitudes. They challenge not only transnational and cosmopolitan solidarity movements, including democratic multicultural and anti-discrimination initiatives, but also the neoliberal economic globalization project in all its editions. In this conjuncture, the WEF stands ready to accomplish the Fourth Industrial Revolution and meet the multiple challenges of migration by focusing on global people management and sophisticated surveillance technology, forging a new global social contract and new security and mobility frameworks. ${ }^{17}$

Despite a strong advocacy for migrant workers' rights and social protection in the governance of migration, the main challenge remains to address the social and individual costs of migration and protect migrant workers against the worst forms of exploitation, informalization and precarization. These are embedded in neoliberal development policy reforms that, paradoxically, breed insecurities and vulnerabilities as the main causes of forced migration. They also imagine migration as a preferable survival strategy, thus reproducing precarity all the way through connectivity in the current formal and informal migration and global production regimes. Thus, a migration for development approach complements already identified economic paradoxes; the implementation of economic development policies that generate inequality and poverty (Panchamukhi, 2000).

Yet, the inclusion of migration into the SDGs may promote migrant workers' rights because several goals and targets invoke universal human rights instruments, social protection and observance of the ILO decent work agenda. However, this will only be possible if development NGOs, civil society, grassroots movements, trade unions and labour movements across North-South divisions critically engage with transformative agendas, development alternatives and contest the technical implementation mechanisms that prevent the real transformative effect of the SDGs (Banks, Hulme, \& Edwards, 2015).

In the context of global migration governance, the CSOs have reinvigorated their mobilization for the UN Global Compact on Migration and the implementation of the migration-related SDGs. Hopefully, this engagement may contribute to a broader consolidation of the PGA/WSFM and a stronger voice of critical NGOs and CSOs such as Oxfam, TMP, GCM and MFA, in order to push for the effective institutionalization of labour and migrant workers' rights in global governance.

\section{Notes}

1. According to ILO estimates, in 2013 there were 155 million migrant workers $(55.7 \%$ men and $44.3 \%$ women), representing $4.4 \%$ of the global workforce. The largest shares of migrant workers live in the US (24.7\%) and Northern, Western and South Europe (23.8\%), followed by Asia and the Pacific (21.9\%).

2. Namely, the 1951 UN Refugee Convention, including its 1967 Protocol, signed by around 150 countries (Martin, 2015).

3. For example, the 1949 Migration for Employment Convention (No. 97) and Recommendation (No. 86), ratified by 49 states, and the 1975 Migrant Workers' Convention (No. 143) and Recommendation (No. 151), ratified only by 23 countries (Martin, 2015). 
4. Critical migration scholars and human rights activists designate the term 'forced migrants' for all categories of migrants who emigrate due to poverty, precarity, deteriorating living and working conditions (see Delgado Wise, 2018).

5. For example, the Economic Community of West African States (ECOWAS), Common Market of the South (MERCOSUR/Brazil, Argentina, Uruguay, Paraguay and Venezuela), North America Free Trade Agreement (NAFTA), European Free Trade Agreement (EFTA) and EU Mobility Partnerships, to name but a few.

6. There are at present more than $20 \mathrm{UN}$ agencies included in the GMG (http://www.globalmigrationgroup. org/gmg-members).

7. https://gfmd.org/process/background.

8. Within this context, member states share Migration and Development M\&D practices compiled in the Platform for Partnerships (https://gfmd.org/pfp).

9. These were the 2008 GFMD/CSD in Manila 'Protecting and Empowering Migrants for Development', and the 2012 GFMD/CSD in Port Louis 'Enhancing the Human Development of Migrants and their Contribution to the Development of Communities and States'.

10. The GFMD Summit Themes are available at https://gfmd.org.

11. The THP 'is an independent, not-for-profit organisation, which brings together diverse stakeholders to seek solutions to migration and refugee challenges' and 'specialises in innovative collaborations in the nexus between business, cities \& migration'. It is a global network of over 4000 individuals, public and civil society organisations and institutions around the world, including the IOM, World Economic Forum (WEF), employers' confederations, cities, corporations such as Siemens, IBM and Manpower, to name but a few (thehagueprocess.org).

12. GFMD 2014-2015, Republic of Turkey, Chair in Office, Final Concept Note (https://gfmd.org/docs/ turkey-2014-2015).

13. Concept Paper GFMD 2016 (https://gfmd.org/docs/bangladesh-2016).

14. https://www.weforum.org/agenda/2018/01/time-new-social-contract-inequality-work-sharan-burrow/.

15. https://www.weforum.org/agenda/2018/01/the-world-needs-qualitative-easing-and-business-must-lead/.

16. Many of these actually reflect various CSOs' claims for a rights-based approach to migration. Thus, SDG 5 promises gender equality and empowerment of all women and girls, and target 5.2 envisions to 'eliminate forms of violence against all women and girls in the public and private spheres, including trafficking and sexual and other types of exploitation'. Goal 8 promises 'sustained, inclusive and sustainable economic growth, full and productive employment and decent work for all', target 8.7 foresees 'to eradicate forced labour, end modern slavery and human trafficking and secure the prohibition and elimination of the worst forms of child labour' and target 8.8 'to protect labour rights and promote safe and secure working environments for all workers, including migrant workers, in particular women migrants, and those in precarious employment.' To meet Goal 10 focused on the reduction of inequalities between and within countries, 'orderly, safe, regular and responsible migration and mobility of people, including through the implementation of planned and well-managed migration policies', and the facilitation of remittances, free trade and investments are specified as specific targets. (https://sustainabledevelopment. un.org/sdgs). To promote just, peaceful and inclusive societies and build 'effective, accountable institutions' is stated as one of the SDGs (Goal 16) for itself, as well as a necessary condition for the realization of sustainable development.

17. https://www.weforum.org/projects/shaping-the-future-of-security-in-travel.

\section{Disclosure statement}

No potential conflict of interest was reported by the author.

\section{Funding}

This article is a contribution to the Swedish Research Links project, 'Migration and development. What space for civil society in global governance? (MIGLINK)', with financial support through the Swedish Research Council [grant number 348-2013-6682]. 


\section{References}

Ackerman, F., Goodwin, N. R., Dougherty, L., \& Gallagher, K. (2000). The political economy of inequality. Washington, DC: Island Press.

Aleinikoff, A. T. (2003). International legal norms and migration: A report. In A. T. Aleinikoff \& V. Chetail (Eds.), Migration and international legal norms (pp. 1-30). The Hague: T.M.C. Asser Press.

Ålund, A., \& Schierup, C-U. (2018). Making or unmaking a movement? Challenges for civic activism in the global governance of migration. Globalizations. doi:10.1080/14747731.2018.1446599

Banks, N., Hulme, D., \& Edwards, M. (2015). NGOs, states, and donors revisited: Still too close for comfort? World Development, 66, 707-718.

Betts, A. (2011). Introduction: Global migration governance. In A. Betts (Ed.), Global migration governance (pp. 1-33). Oxford: Oxford University Press.

Brenner, N., Peck, J., \& Theodore, N. (2010). After neoliberalization? Globalizations, 7(3), 327-345.

Buckley, K. M. (2013). Global civil society and transversal hegemony: The globalization-contestation nexus. Oxon: Routledge.

Carroll, T., \& Jarvis, D. S. L. (2015). Markets and development: Civil society, citizens, and the politics of neoliberalism. Globalizations, 12(3), 277-280.

Castles, S. (2011). Bringing human rights into migration and development debate. Global Policy, 2(3), 248-258.

Cox, R. W. (1977). Labour and hegemony. International Organization, 31(1), 385-424.

Crépeau, F., \& Atak, I. (2016). Global migration governance. Avoiding commitments on human rights yet tracing course for cooperation. Netherlands Quarterly of Human Rights, 34(2), 113-146.

Delgado Wise, R. (2018). Is there a space for counterhegemonic participation? Civil society in the global governance of migration. Globalizations. doi:10.1080/14747731.2018.1484204

Egels-Zandén, N. (2009). Transnational governance of workers' rights: Outlining a research agenda. Journal of Business Ethics, 87(2), 169-188.

Fitzpatrick, P. (2009). 'The new constitutionalism': The global, the postcolonial and the constitution of nations. Law, Democracy and Developmet, 87(2), 169-188.

Fraser, N. (2017). From progressive neoliberalism to Trump - and beyond. What made Trump and Trumpism possible is a crisis of hegemony. American Affairs, 1(4), 46-64.

Gamlen, A., \& Marsh, K. (2011). Introduction: Modes of governing global migration. In A. Gamlen \& K. Marsh (Eds.), Migration and global governance (pp. xiii-xxxiii). Cheltenham: Edward Elgar.

GCIM. (2005). Migration in an interconnected world: New directions for actions. Geneva: Global Commission on International Migration.

Geiger, M., \& Pécoud, A. (2010). The politics of international migration management. Houndmills: Palgrave Macmillan.

Geiger, M., \& Pécoud, A. (2014). International organisations and the politics of migration. Journal of Ethnic and Migration Studies, 40(6), 865-887.

Georgi, F. (2010). For the benefit of some: The international organization for migration and its global migration management. In M. Geiger \& A. Pécoud (Eds.), The politics of international migration management (pp. 45-72). Basingstoke: Palgrave MacMillan.

Grugel, J., \& Piper, N. (2011). Global governance, economic migration and difficulties of social activism. International Sociology, 26(4), 435-454.

Harvey, D. (2005). A brief history of neoliberalism. Oxford: Oxford University Press.

Hosseini, S. A. H., Gills, B. K., \& Goodman, J. (2017). Toward transversal cosmopolitanism: Understanding alternative praxes in the global field of transformative movements. Globalizations, 14(5), 667-684.

ILO. (2006). ILO's multilateral framework on labour migration; non-binding principles and guidelines for a rights based approach. Geneva: International Labour Office. 
ILO. (2010). International labour migration: A rights-based approach. Geneva: International Labour Office.

Kalm, S. (2010). Liberalizing movements? The political rationality of global migration management. In M. Geiger \& A. Pécaud (Eds.), The politics of international migration management (pp. 21-44). Basingstoke: Palgrave Macmillan.

Kalm, S., \& Uhlin, A. (2015). Civil society and the governance of development. Opposing global institutions. Basingstoke: Palgrave MacMillan.

Koser, K. (2010). Introduction: International migration and global governance. Global Governance: A Review of Multilateralism and International Organizations, 16(3), 301-315.

Kunz, R., Levenex, S., \& Pannizon, M. (2011). Introduction: Governance through partnerships in international migration. In R. Kunz, S. Levenex, \& M. Pannizon (Eds.), Multilayered migration governance: The promise of partnership (pp. 1-20). Abingdon and New York: Routledge.

Likić-Brborić, B., \& Schierup, C.-U. (2015). Labour rights as human rights? Trajectories in the global governance of migration. In C.-U. Schierup, R. Munck, B. Likić-Brborić, \& A. Neergaard (Eds.), Migration, precarity, and global governance: Challenges and opportunities for labour (pp. 223-244). Oxford: Oxford University Press.

Maas, W., \& Koser, K. (2010). A state of the art review. Towards global governance of international migration. 15 years of intergovernmental recommendations and conclusions. The Hague: The Hague Process on Refugees and Migration (THP).

Martin, P., Martin, S., \& Weil, P. (2006). Managing migration. The promise of cooperation. Lenham: Lexington Books.

Martin, S. F. (2015). International migration and global governance. Global Summitry, 1(1), 64-83.

Mayer, W. F., \& Phillips, N. (2017). Outsourcing governance: States and the politics of a 'global value chain world'. New Political Economy, 22(2), 134-152.

McKeon, N. (2018). Getting to the root causes of migration in West Africa - whose history, framing and agency counts? Globalizations. doi:10.1080/14747731.2018.1503842

MFA. (2009). Mobilizing migrant community and civil society voices for the second global forum on migration and development (GFMD): The migrant forum in Asia experience. Las Piñas: Migrant Forum in Asia.

Milanovic, B. (2018). Global inequality: A new approach for the age of globalization. Harvard, MA: Harvard University Press.

Mirowski, P. (2013). Never let a serious crisis go to waste. How neoliberalism survived the financial meltdown. London: Verso.

Munck, R. (2007). Globalisation and contestation: The new great counter-movement. New York, NY: Routledge.

O’Brien, R., Goetz, A. M., Scholte, J. A., \& Williams, M. (2000). Contesting global governance: Multilateral economic institutions and global social movements. Cambridge: Cambridge University Press.

Omelaniuk, I. (2012). Introduction: Making the connections between migration and development. In I. Omelaniuk (Ed.), Global perspectives on migration and development. GFMD Puerto Vallarta and beyond (pp. 1-25). London: Springer.

Overbeek, H. (2002). Globalisation and governance: Contradictions of neo-liberal migration management. HWWA Discussion Paper. No. 174. Hamburg: Hamburg Institute of International Economics.

Panchamukhi, V. R. (2000). Five recent paradoxes and anomalies of economics. Asia-Pacific Development Journal, 7(2), 1-31.

Pécoud, A. (2018). What do we know about the international organization for migration. Journal of Ethnic and Migration Studies, 44 (10): 1621-1638.

Phillips, N. (2009). Migration as development strategy? The new political economy of dispossession and inequality in the Americas. Review of International Political Economy, 16(2), 231-259.

Pritchett, L. (2006). Let their people come. Braking the gridlock on international labor mobility. Washington, DC: Center for Global Development.

Rodrik, D. (2011). The globalization paradox. Democracy and the future of the world economy. New York London: W. W. Norton \& Company.

Rother, S. (2018a). The global forum on migration and development as a venue of state socialisation: A stepping stone for multi-level migration governance? Journal of Ethnic and Migration Studies. doi:10.1080/ 1369183X.2018.1441605.

Rother, S. (2018b). Angry birds of passage - migrant rights networks and counter-hegemonic resistance to global migration discourses. Globalizations. doi:10.1080/14747731.2018.1472860 
Sachs, J. D. (2012). From millennium development goals to sustainable development goals. Lancet, 379, 2206-2211.

Schierup, C.-U., Ålund, A., \& Likić-Brborić, B. (2015). Migration, precarization and the democratic deficit in global governance. International Migration, 53(3), 50-63.

Schierup, C.-U., \& Jørgensen, M. B. (2016). From "social exclusion" to "precarity": The becoming-migrant of labour. An introduction. In C.-U. Schierup \& M. B. Jørgensen (Eds.), Politics of precarity (pp. 1-29). Leiden: Brill.

Smith, J. (2012). Transnational activism and global social change. In H. Mosknes \& M. Melin (Eds.), Global civil society. Shifting powers in a shifting world (pp. 9-26). Uppsala: Uppsala University.

Stiglitz, J. (2002). Globalization and its discontents. London: Allen Lane The Penguine Press.

Thérien, J.-P. (2005). Beyond the north-south divide: The two tales of world poverty. In R. Wilkinson (Ed.), The global governance reader (pp. 218-238). London: Routledge, Taylor \& Francis Group.

Vosko, L. F. (2002). "Decent work": The shifting role of the ILO and the struggle for global social justice. Global Social Justice, 2(1), 19-46.

WCSDG. (2004). A fair globalization: Creating opportunities for all. Geneva: ILO.

Woolfson, C., \& Likic-Brboric, B. (2008). Migrants in the unequal burdening of "toxic" risk: Towards a new global governance regime. Debatte: Journal of Contemporary Central and Eastern Europe, 16(3), 291-308. 


\title{
Irregular migration and migrants' informal employment: a discussion theme in international migration governance
}

\author{
Gülay Toksöz
}

\begin{abstract}
Unequal development in neoliberal globalization causes economic, social, and political problems that force people into irregular migration and to become part of informal labour markets. Although informal sector enterprises in both developed and peripheral countries depend mainly on migrant labour, this demand is usually not recognized in official migration policies, thus increasing the vulnerability of migrant workers. The relationship between informal employment and irregular migration has been one of the main themes in the Global Forum on Migration and Development (GFMD) since its foundation. The general approach in the GFMD can be summarized as acceptance of this interrelationship, without discussing the underlying causes behind it. This article reviews discussions in the literature by focusing on the interrelations between the informal sector, informal employment, and irregular migration. Then, it investigates how this issue has been tackled in the Forum's Government and Civil Society Days.
\end{abstract}

\section{Introduction}

Migration flows are an integral part of the current economic, social, and political transformations caused by contemporary neoliberal globalization (Castles, 2015, pp. 9-10). People move because global capitalism has left them unable to conduct simple livelihood activities or because they lack the capabilities required to meet their basic needs (Delgado Wise, Covarrubias, \& Puentes, 2013). Simultaneous to this pressure towards migration, developed countries have increased their restrictions on labour immigration, especially for unqualified workers, thereby forcing people from peripheral countries to search for irregular ways to migrate.

Castles, Cubas, Kim, and Özkul (2012, pp. 119-120) define the factors causing irregular migration according to their importance as follows. First, national laws and regulations that set the border between the desired and undesired forms of human mobility are the main cause. Although governments officially restrict some migrant groups in the name of national sovereignty, they tacitly allow irregular migration and informal employment of migrants to meet the domestic employers' demands. Second, neoliberal globalization increases inequality both between the Global North and South as well as within countries and regions. Some thinkers with a 'Southern' perspective on migration and development focus more on the uneven development as an inescapable aspect of monopoly capitalism. They try to demystify irregular migration as a result of state policies related to capitalist interests aimed at satisfying labour demand by taking advantage of an abundant reserve 
of foreign vulnerable labour that than can be deprived from social benefits and basic labour rights. Accordingly, these thinkers assert that increasing social inequalities through the concentration of capital, power, and wealth in a few hands, and the dispossession, marginalization, and exclusion of large segments of the population have caused compulsive displacement, defined as 'forced migration' (see Delgado Wise, 2018; Delgado Wise, 2009, 2013; Delgado Wise et al., 2013).

The mobility of people in neoliberal globalization, defined as 'forced migration', takes place under circumstances of labour market deregulation all over the world. The resulting informalization of labour markets means people work under exploitative conditions. Informal employment, which is a significant feature of labour markets in both central and peripheral countries, mainly occurs in the informal sector. In post-industrial countries, informal sector enterprises primarily depend on migrant labour due to a lack of supply, whereas in peripheral countries there is, to a certain extent, competition and substitution between natives and migrants for jobs in informal enterprises. Despite these differences between countries and regions, it is still possible to observe some similar patterns. In a segmented labour market, the informal sector enterprises' main workforce consists of migrants, especially irregular.

This article tries to answer two main questions. First, how are the informal sector, informal economy, informal employment, and irregular migration interrelated, and how do they help each other's expansion in the context of neoliberal globalization? Second, how is this relationship addressed and evaluated in the context of the Global Forum on Migration and Development (GFMD) in Government Days and Civil Society Days? In order to answer these questions, the first section reviews the literature from a historical perspective to investigate the interrelationship between the informal sector, informal economy, informal employment, and irregular migration. Thereafter, the second and third sections discuss the similarities and differences among approaches by examining GFMD documents from Government Days for 2007-2015 and Civil Society Days for 2011-2015, respectively. The concluding section summarizes the differences and similarities revealed by this analysis. The general approach in the GFMD can be summarized as an acceptance of the interrelationship between informal economy and irregular migration without discussing the underlying reasons behind this relationship. Particularly, labour market needs assessment is suggested as the solution to the problems in the Government Days, while the human rights of irregular migrants are brought to the fore in the Civil Society Days.

\section{Informal labour markets and irregular migration}

\section{The informal sector, informal economy, and informal employment}

The conceptualization of the informal sector dates back to 1972, when the International Labour Organisation (ILO) Employment Mission in Kenya wrote a report analysing the employment situation there. In its analysis, the term informal sector was used to define small, family-owned enterprises for income generation (Bangasser, 2000, pp. 9-10). Since then, the ILO has conducted many studies to identify various aspects of informality. Those people working in units with 'informal' characteristics in relation to, for example, legal status, enterprise registration, size, employee registration, and bookkeeping practices are in the informal sector employment. Informal employment is thus a job-based concept covering those whose main jobs lack basic social or legal protection or employment benefits. Such workers may be found in both the formal and informal sectors, or in households (Carr \& Chen, 2002; Hussmanns, 2002; ILO, 2002, 2013). Research on the informal sector in periphery countries, especially in Latin America, reveals that the persistence of small 
enterprises (which had been expected to be replaced by modern factories) is due to the failure of capitalist industrialization to provide people with sufficient formal employment opportunities. Through both backward and forward linkages, such enterprises have complemented the formal sector by supplying cheap basic consumer goods for factory workers or using factory products as intermediate goods (Tokman, 1990, 1992).

Neoliberal globalization and the deregulation of labour markets have made the complementarity between the formal and informal economic sectors constituting the informal economy more evident. Castells and Portes (1989, p. 12) define the informal economy as 'a process of income generation characterized by one central feature: it is unregulated by the institutions of society, in a legal and social environment in which similar activities are regulated'. They emphasize that the informal economy has expanded globally, even in highly institutionalized economies, at the expense of formalized work relationships to enable employers to evade state-imposed regulations and trade union interventions through collective bargaining. One widely used mechanism for this evasion has been outsourcing. The accommodation of capital to globalization by avoiding regulatory regimes through outsourcing and subcontracting to smaller firms operating with lower profit margins in the informal sector is termed 'informalization from above' (Slavnic, 2010). That is, informal employment in small firms has proliferated with the support of large enterprises because of the former's ability to reduce labour costs.

During the globalization process, the informal sector and informal employment also characterize the economies of the mega-cities of post-industrial countries. The residents of mega-cities become simultaneously victims of economic restructuring and active participants in the informal economy. As such, their economic activities can be seen as an attempt 'to achieve some level of economic security in a highly precarious environment' (Leonard, 2000, p. 1082). The work of such people, who include low-income or poorly educated workers, small business people active in intensive work and highly competitive markets, as well as women and immigrants, constitutes informalization from below' (Slavnic, 2010). The more they become marginalized and exploited, the more they are pushed to participate in the informal economy to survive. Given these links, informalization from below and informalization from above should be analysed in terms of their mutual relationship rather than separately.

People working under exploitative conditions without legal protection are known as the core of the precariat. According to Standing (2011, p. 10), this newly emerging social class of the neoliberal era includes people who lack labour market security, employment security, job security, work security, skill reproduction security, income security, and representation security. The main forms of informal employment demonstrate all these characteristics of precarity. Although precarious jobs in developed countries are usually registered, they nevertheless offer only limited benefits and social protection, as in the case of self-employment, temporary, or part-time wage employment. Informal jobs in peripheral countries, on the other hand, are completely unprotected as they are both unregistered and outside the scope of social security and labour laws (ILO, 2013).

\section{Migrant labour in the informal sector and informal employment}

In his well-known work on migrant labour, Piore (1979) describes the dual structure of the labour market in industrialized countries; namely, a primary sector with secure jobs and a secondary sector with insecure jobs. At the bottom of the job hierarchy are insecure jobs in industry, construction, or agriculture. Because demand for these jobs fluctuates widely due to seasonal factors or business cycles, they are considered appropriate for the migrant workforce. In addition, industrial 
restructuring in western countries, which involves subcontracting to smaller firms to reduce costs and compete with cheap imports, has led to a 'downgraded' manufacturing sector with an increasing role for ethnic business using regular or irregular migrants (Sassen, 1997, p. 5).

As the bulk of manufacturing activities has been transferred to various regions in economically less-developed countries over the last quarter of the twentieth century due to the new international division of labour (Coffey, 1996; Kiely, 2008), the need for migrants has become apparent in more unstable sectors in the developed world. Such sectors include small-scale enterprises in agriculture, tourism, construction, and domestic work, as examined mostly in southern European countries (Castles et al., 2012; Finotelli, 2011; King, 2000; Näre, 2011; Reyneri, 1998, 2002, 2004; Veiga Martinez, 1999, 2007). Western European countries have seen similar patterns regarding economic sectors, enterprises, and informal employment of regular or irregular migrants from new EU member states from Central and Eastern Europe or former Soviet Union countries (Brinkmeier, 2011; EC, 2009; Trimikliniotis \& Fulias-Sourroulla, 2013). These usually family-owned, small-sized enterprises share the features of informal sector enterprises. Whether ethnically based or not, they mostly depend on the informal employment of immigrants. Official migration policies ignore these enterprises' need for low-waged, low-skilled workers due to the lack of supply from natives for the jobs they offer. ${ }^{1}$

Ethnic entrepreneurship is a twofold issue. Such entrepreneurs are confronted with the difficulty of accessing markets and sources. Furthermore, due to harsh competition, they cannot usually comply with the laws, so exhibit the characteristics of informal sector enterprises. As these ethnic businesses lack the power to influence government migration policies regarding their need for unskilled labour as well as because of immigration restrictions, their labour demands are met by informal markets. Research on ethnic minority businesses in clothing and restaurants in Britain, for example, reveals that their survival depends on recruiting undocumented co-ethnics seeking jobs through migrant networks or family members. Very low-profit margins usually prevent them from employing regular and registered migrants. Exploitation of their workers and the self-exploitation of owners through the extremely intensive work and long working hours exhibit a basic feature of these enterprises and exemplify informalization from below. In this way, they also provide valuable and affordable goods and services for consumers (Jones, Monder, \& Edwards, 2007).

Domestic and care work constitute the main source of employment for a great number of migrant women. The feminization of international labour migration (Castles \& Miller, 2003, p. 9) as a result of demographically related care deficits, as well as women's increasing labour force participation and changes in the gendered welfare regimes of developed countries mean that more migrant women are needed in care and health services in order to reduce public expenditure (Ehrenreich \& Hochschild, 2003; Gendera, 2011; Kaşka, 2009; Kofman, Phizacklea, Raghuram, \& Sales, 2000; Lazaridis, 2007; Lutz, 2007; Näre, 2011; Simonazzi, 2008). As domestic work is generally considered women's work due to the worldwide gender-based divisions of labour, it is rendered invisible and devalued, and is one of the least protected areas of employment when performed as waged work, whether by native or migrant women. Non-protection is not a result of labour market deregulation. This type of work has been unregulated from the very beginning and therefore a very significant component of informal employment worldwide, regardless of a country's level of development. In EU countries, informality is not only limited to irregular migrants, but is also widespread among those with regular status, particularly migrant women deemed by negative stereotypes as suitable for low-status, lowpaying jobs (Maroukis, 2009, pp. 31-32; Trimikliniotis \& Fulias-Sourroulla, 2013, pp. 63-66).

According to various researchers, migrants form the bulk of people working in and living under precarious conditions in receiving countries and represent a large share of the world's precariat 
(Standing, 2011, p. 90). Standing (2011) finds that irregular migrants are the most vulnerable, whether in developed or less-developed countries, followed by temporary or seasonal migrants. Woolfson and Likic-Brboric (2008, p. 296) prefer the term 'hyper-precarity', particularly during economic crises, to define the situation of migrants, especially those undocumented and working under especially disadvantaged circumstances and exposed to abuse by employers. Highlighting the gender dimension of precarity, Trimikliniotis and Fulias-Sourroulla (2013, p. 71) argue that migrant women constitute the core of the global precariat. For Schierup, Alund, and Likic-Brboric (2014, p. 2), the precariat reflects a duality in that it not only refers to a subordinated group of migrants deprived of basic human and labour rights, but also provides a source for social justice movements with the potential of resistance.

For social justice movements, campaigning for human and labour rights, as well as migrants' rights have become an essential part of their activities and engagement. Among various fundamental conventions on workers' rights, including migrant workers' rights, the ILO's Multilateral Framework on Labour Migration (2006) was developed to reinforce the decent work agenda for labour migrants and to implement a rights-based approach to international migration, including irregular migrants. Although considered an impressive document, it suffers from the non-binding character of ILO declarations (Likic-Brboric \& Schierup, 2012, p. 15). However, the Decent Work Agenda is viewed as important for mobilizing migrants' organizations in the 2008 GFMD to defend a rights-based approach to migration within the context of the right to development and decent work (Likic-Brboric \& Schierup, 2012, p. 24).

\section{Global forum on migration and development}

The GFMD was founded in 2007 as an informal dialogue platform on migration issues at the initiative of UN Secretary General Kofi Annan after the UN High-Level Dialogue (HLD) on Migration and Development in 2006. Despite globally increasing migratory movements, there is no formal multilateral institutional framework regulating states' policies on international migration. Moreover, there is not any UN organization for migration besides the UN Refugee Agency (UNHCR), the UN agency for asylum protection. Due to opposition from northern states for a UN-based organization to protect their national sovereignty in the area of migration, the GFMD has offered an informal space for states to engage in dialogue and information-sharing, and a potential space for international migration governance with the increasing participation of civil society (Betts, 2011). ${ }^{2}$

The International Organisation for Migration, an intergovernmental organization on migration, was approved as an UN-related organization as late as 2016. In GFMD Government Days, the representatives of sending and receiving countries discuss the issue of international migration and the situation of migrants from their perspectives, seeking to establish a common point of view based on the interlinkages of migration with development. ${ }^{3}$ In GFMD Civil Society Days, civil society including diaspora and migrant organizations, human rights and development groups, labour unions and representatives from academia and the private sector prepare action plans and recommendations, engaging in direct dialogue with governments during the Common Space. ${ }^{4}$

\section{The GFMD government days approach: discussing not the systemic causes but recognizing the reality of irregular migrants 5}

Labour migration has been one of the main themes discussed in GFMD meetings. This section considers how the relationship between informal employment and irregular migration is defined and 
discussed, as well as the recommendations developed in the Forums' Government Days. However, these recommendations have a non-binding character; therefore, it is uncertain how much they are implemented. The Government Days usually take the form of exchanging best practices to inform about country experiences based on recommendations. Nevertheless, evaluating their implementation is beyond the scope of this article.

The GFMD's initial and ongoing focus on economic development through the remittances of migrants and diaspora as instruments of development in their countries of origin has been criticized as a limited approach that ignores the context of neoliberal globalization; the root causes of migration and migrants' contributions to receiving societies while also neglecting migrants' human rights. Based on neoclassical theory and neoliberalism, this approach assumes that free market economies operate efficiently to regulate the needs of the labour market (Delgado Wise et al., 2013). In line with this perspective, documents of GFMD Government Day meetings frequently claim that irregular migration is closely related to inadequate labour market need assessments. When employers' labour demands, particularly for low-skilled migrants, are not met, employers fulfil their needs by informally employing irregular migrants. Hence, the GFMD often recommends opening channels for regular circular migration.

\section{Migrants in the informal sector}

The first GFMD, held in 2007 in Belgium as a developed receiving country, aimed to highlight the benefits of temporary or circular migration. The round-table discussions on the contribution of temporary labour to development efforts recommended setting up a model Circular Migration Programme. However, at the following GFMDs, organized in 2008 in the Philippines and 2010 in Mexico, the discourse partly changed because both conference hosts are sending countries. Irregular migration appeared on the agenda with a focus on minimizing the negative impacts of irregular migration, and emphasizing migrant vulnerability and protection. Still, there was no discussion referring to neoliberal globalization as deepening inequalities and fostering unprotected employment forms in the informal and formal sectors of sending and receiving countries. The Philippines' conference round tables focused on protecting migrants' rights and opening channels for regular migration. One of the main elements for approaching migration as a human rights issue has been the ratification of international treaties such as the 1990 UN Convention and relevant ILO conventions. The disadvantages experienced by migrant workers either in regular or irregular statuses in the informal sector were tackled with an emphasis on their remittance capacity.

The GFMD 2010 in Mexico went further by discussing the situation of irregular migrants and the causes of irregular migration at various round tables. This development was also related to the inclusive approach of the Mexican government to create a 'Common Space' among government representatives and civil society organizations. Even some of the participants of the global grassroots movement, People's Global Action, participated in the common space to voice their joint statement calling for a human rights-centred approach to migration and development (Rother, 2011). For example, a round table on 'Joint Strategies to Address Irregular Migration' included three main discussions: the causes of irregular migration, mechanisms to protect the rights and access to social services of migrants with irregular status, and instruments to solve irregular migration problems. ${ }^{6}$ In these discussions, however, it was not the systemic causes of informal employment as a realm of existence for irregular migrants that were discussed, but the demand for migrant labour in small informal sector enterprises and households, which could not recruit natives, was brought to the fore. The background paper stated that: 
[M]igrant involvement in key growth sectors such as agriculture, construction and services, contributes significantly to the welfare of the population. For example, domestic work and care of children and the elderly, usually poorly paid and stigmatized, is a fundamental contribution of migrants to the welfare of families at both ends of the migration spectrum. (...) Unless the imbalance in supply and demand is adequately addressed, irregular migration will continue and efforts to combat irregular migration will only force the operation deeper underground with grave consequences for victims. ${ }^{7}$

Emphasizing the migrants' contribution to the welfare of the receiving societies, the document recommended legalizing irregular migrants and preventing irregular migration by identifying and better matching real labour market needs with appropriate labour. ${ }^{8}$ According to Rother (2011, p. 185), a stronger representation of the civil society in the GFMD Mexico 2010 meant that human rights and human development have therefore become part of the discourse.

In the Swiss chair's programme for 2011, the issue of irregular migration was elaborated on with an emphasis on development-related causes and the implications of irregular migration, especially the human rights needs and special vulnerability of migrant children, women, and men in irregular situations. ${ }^{9}$ Two thematic meetings were organized within this framework. The concept note of the thematic meeting on 'Cooperation Strategies among States to Address Irregular Migration: Shared Responsibility to Promote Human Development' stressed that irregular and regular migration share similar drivers, namely the socio-economic conditions of sending and receiving countries. In addition, the labour market segmentation of formal and informal sectors in destination countries creates opportunities for irregular work, regardless of workers' migratory status. ${ }^{10}$ Thus, this meeting acknowledged the structural conditions conducive to the informal employment of migrant workers. The other thematic meeting was 'Addressing Irregular Migration through Coherent Migration and Development Strategies'. Its concept note clearly outlined the global economic inequalities forcing people to migrate and stressed how ignoring the need to include migrant workers in official migration policies increases irregular migration:

Very often economies of developed countries need unskilled workers while their publics would not accept a labour recruitment policy, which results in interest conflicts and paves the way to side or backdoors. (...) Most migration flows today are an integral aspect of global inequality. Unless states go beyond the securitization of the migration area and address the current patterns of global inequality and other development-related causes of migration, it needs to be acknowledged that irregular migration will continue for the foreseeable future, although it may be possible to reduce its scale. ${ }^{11}$

It is interesting to note that these preparatory papers' insightful evaluations of the situation, which are quite similar to the views of critical social scientists, took on a far more moderate form in the final reports, which merely stated that opening up legal channels for labour mobility around the clearly defined needs of all parties can mitigate the factors causing or encouraging irregular migration. Thus, the limited efforts to reveal the structure of labour markets causing the informal sector and informal employment, as well as why irregular migrants constitute the core of the precariat disappear in the official papers. That is, the referral to neoliberal globalization as deepening inequalities and fostering unprotected forms of employment completely vanishes.

\section{The most significant form of informal employment: domestic work}

Domestic work and migrant domestic workers have become a recurring theme in various GFMD meetings. Although the gender-based division of labour devaluing women's care work, making it invisible and the least protected area of employment, have not been adequately discussed, the vulnerability and even neglect of the basic human rights of migrant domestic workers in receiving 
countries motivated some sending and receiving countries to tackle the issue in the Government Days. First, in the GFMD 2010 in Mexico, a round table on 'Migration, Gender and Family' identified migrant domestic workers as a particularly vulnerable group at the interface of migration and development. The need for special protection was underlined particularly for women or children working in countries that do not give full legal recognition to this kind of work. ${ }^{12}$

In the following GFMD meeting in 2011, the Swiss chair organized a special thematic meeting focusing on Jamaica and Ghana regarding migrant domestic workers. Both meetings stressed the critical characteristics of domestic work, namely its private nature and location, which often leaves such workers vulnerable to exploitation and abuse, and creates the need for social protection. The main outcome was a gender-sensitive checklist to protect and support migrant domestic workers, intended as a practical guide to governments setting up policies, legislation, and programmes to implement ILO Convention 189 (Decent Work for Domestic Workers), the CEDAW General Recommendation, and the Migrant Committee's General Comment. ${ }^{13}$ At the meeting in Switzerland, the round table on 'Labour Mobility and Development' devoted a session to 'Global Care Workers at the Interface of Migration and Development' and adopted core messages and recommendations based on the discussions in previous thematic meetings. ${ }^{14}$

Further discussion on migrant domestic workers took place at the GFMD 2012 in Mauritius through a round table on 'Protecting Migrant Domestic Workers - Enhancing their Development Potential'. Discussions focused on the status of ILO Convention 189 implementation, with Mauritius and the Philippines sharing their experiences about the ratification process. However, the discussion's conclusions admitted that ratification of 'the ILO Convention is an improvement but it is not sufficient. National laws must be enacted or adjusted to ensure domestic workers' protection'. ${ }^{15}$

Indeed, the increasing number of both sending and receiving countries ratifying the ILO Convention (23 countries by October 2016) suggests that governments are more willing to protect domestic workers than other groups of informal workers. For receiving countries, this can be explained by the provision of cheap care services enabling governments to save social expenditures and for sending countries women's being loyal remittance senders.

\section{Migrant/diaspora entrepreneurship and informal sector enterprises}

Since 2007, one of the main themes of all the forums and discussed in various sessions has been the role of migrants and diaspora in development and ways of increasing their contributions. However, migrants' contributions have been mostly evaluated with respect to the countries of origin, with the developmental impact of the diaspora in receiving countries being rather disregarded. This attitude was also decisive in neglecting the structural constraints that small-scale migrant enterprises face in receiving countries and how their labour force needs usually lead to informal employment practices using irregular migrants. In various GFMD round tables and related sessions (2007 in Brussels, 2008 in Manila, 2009 in Athens, 2012 in Mauritius and 2014 in Stockholm), there was a wide range of discussion concerning the funding function of remittances for developing countries, and the establishment of business partnerships with migrant/diaspora entrepreneurship in countries of origin.

At the 2015 GFMD in Istanbul, a round table session considered private sector-government partnerships to support migrant and diaspora entrepreneurship and job creation, with a focus on smalland medium-sized enterprises (SMEs). This was the first time such businesses had been discussed in the forum. The background paper differentiated between 'necessity entrepreneurs', who decide to run a business because the labour market offers them no other viable options, and 'opportunity entrepreneurs', who recognize opportunities in the market and tend to have strong business acumen. 
The paper tended to have a preference for the latter as they 'have a propensity for innovation and the creation of higher value ventures', ${ }^{16}$ as was demonstrated through selected examples of successful migrant or diaspora entrepreneurs.

In general, the documents examined here reveal that government representatives comprehend that ignoring the needs of labour markets in receiving countries leads to irregular migration and increases informal employment. In order to respond to the need for migrants in low-skilled jobs neglected in official migration policies, the documents prefer to use the economic terminology of needs assessment of labour markets. This way of framing the problematic of irregular migration is rather narrow and misleading. Essentially, it usually fails to acknowledge the systemic causes of irregular migration, that is, the structural changes in labour markets towards deregulation and informalization, and informal employment as an employer strategy to reduce costs and the governments' support through restrictive immigration policies. No differentiation is made between the informal sector and the informal economy, namely the needs of informal sector enterprises based on subsistence activities and other profit-orientated enterprises supporting informal economic activities for cost reduction purposes. Consequently, the focus on development instrumentalizes migrants as remittance senders and neglects their human rights with discussions about migration management and building necessary partnerships between countries of origin, transit, and destination in order to meet demands for labour through circular migration policies.

\section{The GFMD Civil Society Days approach to irregular migration and informal employment}

The understanding of development in Civil Society Days goes far beyond an economic perspective. The alternative approach to development manifests itself in the way the participants advocate for the protection of migrant workers and their families, and promote rights-based labour migration policies. According to Bloom (2014), since the first meeting, civil society groups have argued that migration should not be limited to development issues, which would ignore migrants' human rights. For such actors, the key measure of success in changing official policies is improvements in the lives of migrants in workplaces, families, and communities (Bloom, 2014, pp. 50-51). Rother (2013) argues that migrant organizations have developed counter-strategies against the disciplining efforts of governments and international organizations, acting as subjects rather than objects of governance.

One strategy is to frame migration through international human rights conventions. Schierup et al. (2014) point out the conflict that the global governance of migration faces, namely between conventions on universal social and labour rights supported by international trade unions, migrant organizations, and academicians on the one hand, and a currently dominant business and tradefocused framework for migration and development represented by the World Trade Organisation on the other hand. Thus, civil society groups criticize the forums for not adequately dealing with the challenge of designing policy tools that address the social and individual costs of migration, as well as not protecting low-skilled migrant workers from the worst forms of exploitation in a mostly unregulated recruitment business, despite strong advocacy for providing social protection for migrants in circular and temporary migration schemes (Schierup et al., 2014, pp. 56-57).

\section{Irregular migrants from the perspective of human rights}

The forum documents do not allow a systematic evaluation of the civil society's approach to the issues of the informal sector, informal employment, and irregular migration. An analysis of the 
documents indicates that, in earlier Civil Society Days, the participants aiming to improve the lives and working conditions of migrants concentrated more on the concrete recommendations rather than discussing the causes. Gradually, discussions have increased on the root causes of inequalities which mobilize people to search for new lives. This is because the little progress related to the recommendations created frustration among the participants.

Since 2011, ${ }^{17}$ meeting themes that have been defined in conjunction with Government Days' topics indicate an interaction between both gatherings. However, Civil Society Days differentiate from the Government Days with their emphasis on migrant protection, while various sessions have been organized on protecting and improving the conditions of migrants in irregular situations. For example, one cluster in the 2011 GFMD government meeting addressed irregular migration through coherent migration and development strategies. Consistent with this, the general theme of the Civil Society Days was 'Taking Action on Labour Migration, Development and the Protection of Migrant Workers and Families' while a subtheme was 'Improving Protection of Migrants Moving or Working in Irregular Circumstances'. In the working session on 'The 'Business' of Irregular Migration', which addressed the demand for irregular labour and its inevitable exploitation, participants broadly agreed that the lack of regular channels for labour migration and family reunification as a state policy, as well as the demand for irregular types of labour in agricultural and domestic work, food processing, construction, and the sex industries encouraged the irregular movement and status of migrants, thereby making them vulnerable to employers, subcontractors, and recruitment agencies. This is similar to the background paper of the 2010 Mexico meeting, mentioned in the former section on Government Days, where the identification of the problems can also be traced with respect to recommendations. Under the theme 'Re-imagining Labour Mobility', the session discussed how to better match labour and skills supply with demand based on better labour market analyses while also considering circular or temporary labour migration. Similar to the recommendations of the Government Days, it suggested that governments create regular channels for circular migration that address labour market needs in cooperation with employers, labour unions, and other social actors. ${ }^{18}$

In their '5-year 8-point Plan of Action' to follow up the 2013 UN HLD, civil societies made a collaborative demand for governments to make both the right to migrate and the right to remain at home with decent work and human security the main development principles. These are among the main principles of an alternative approach to migration, development, and human rights (Delgado Wise et al., 2013). In the Plan of Action, two points particularly emphasized migrant protection. Point 5 covered the enactment and implementation of national legislation to comply with the full range of provisions in international conventions pertaining to migrants, including beyond the labour sphere. Meanwhile, point 8 covered mechanisms that guarantee labour rights for migrant workers equal to the rights of nationals while affirming the state's role to protect the rights of all workers. Nevertheless, the civil society declarations following the HLD meetings suggest contrasting assessments: One is a moderate optimism regarding the government approach to the necessity of incorporating human rights into migration management at various levels, while the other is scepticism about whether rhetorical recognition of human rights will lead to binding commitments (Schierup et al., 2014, p. 57).

The central theme of the 2014 GFMD Civil Society Days was 'Shaping Migration and Development Goals: Global Movement, Change on the Ground', ${ }^{19}$ which included labour mobility, labour rights, and decent work, with sessions on social protection and migrant labour recruitment. The Civil Society Stockholm Agenda established migrant and migration-related goals and targets for the post-2015 global and national development agendas. ${ }^{20}$ This document is particularly important 
for its critical emphasis on the root causes and conditions forcing people to migrate, particularly global inequalities driven by current development and economic paradigms. Furthermore, it focused on the need for a rights-based, people, and nature-centred development framework. Regarding the Post15 Sustainable Development Agenda, all the goals and targets defined in the Stockholm Agenda call on both receiving and sending countries to make migration a choice in a world worth living in, rather than a necessity.

Civil society representatives welcomed Turkey's proposal as chair of the 2015 GFMD to include human security and forced migration in the Forum's concept paper and agenda. ${ }^{21}$ During the Civil Society Days of 2015, in acknowledgment of the recently forced displacement of millions due to the Syrian crisis, the opening plenary debate was dedicated to 'Safe Migration: Root Causes, Route Choices and Alternatives to Forced and Dangerous Migration'. A special session considered the protection of and durable solutions for Syrian refugees. Recommendation 4, in an attempt to define forced migration more broadly, called on governments to do much more to address the root causes of forced migration. This included addressing environmental degradation and climate change, the lack of livelihoods and decent work, and conflict and human rights abuses in countries and regions of origin. It also asked that states recognize and invest in forced migrants' human development and potential, including through access to labour markets, education for children, local integration, resettlement, family reunification, and pathways to permanent residence and citizenship. $^{22}$

However, the meaning of 'root causes' appears to differ according to the actors using the term. Van Hear and Castles (2011, p. 287) argue that root causes 'lie in the imbalances of power and resources in the global political economy and addressing them would require a major transformation in the distribution of power and resources worldwide'. Meanwhile, northern states prefer to refer to driving factors in origin countries such as violence, human rights violations, disparities in living standards, and poverty, which necessitate efforts at poverty alleviation and conflict reduction besides tighter border controls (Van Hear \& Castles, 2011, pp. 301-302). The critical approach to root causes, on the other hand, considers forced migration as not only based on violence, conflict, and catastrophe but also on dispossession, exclusion, and unemployment resulting from unequal development. It, therefore, envisages the right to development in countries of origin leading to the right not to migrate by reversing the structural and political factors that cause forced migration (Delgado Wise et al., 2013, pp. 436-438). Although this critical approach is partially reflected in the documents of civil society groups, it was not discussed with a clear understanding of the root causes because of the diversity among the participants of civil society.

\section{Migrant/diaspora entrepreneurship}

In general, all of the Civil Society Days' sessions on migrant/diaspora entrepreneurship tackled the issue in a similar fashion to the Government Days. For example, at the 2012 Civil Society Days in Mauritius, the theme was 'Operationalising Protection and Human Development in International Migration', with one working session on 'Engaging Diaspora as Entrepreneurs, Social Investors and Policy Advocates'. This session discussed the role that migrants and diaspora can play in development as entrepreneurs, investors, and consumers, together with the protection of their property rights, good infrastructure provisions and access to justice, credit and skills development. For the better engagement of migrants and diaspora in development, the meeting called on governments to introduce conducive legal and financial frameworks to promote migrants as entrepreneurs through financial support, capacity building, business networking, legal protection, and legal 
provisions for dual citizenship. ${ }^{23}$ However, the meeting did not consider how government recruitment policies fail to address the workforce needs of small migrant enterprises.

In the GFMD 2014 in Sweden, the civil society recommended that governments in sending and receiving countries facilitate migrants and diaspora's contributions to job creation. Despite these remarks on the job creation potential of diaspora, similar to the former meetings they did not discuss how official migration policies ignoring the labour needs of informal sector enterprises leads to their supply through irregular migration channels.

At the 2015 Civil Society Days in Istanbul, a session related to the Government Days' topic was again about supporting migrant/diaspora entrepreneurship and job creation. The discussion highlighted the ability of diaspora enterprises to support workers in the informal economy, which is dominated by women in many sending countries, helping them to grow their businesses. The second session goal was to promote the practice of decent jobs and ethical practice in business; that is, not only facilitating job creation by the diaspora but also emphasizing decent job creation. A guiding question for discussion, therefore, focused on the types of businesses that facilitate this. ${ }^{24}$ Recommendation 6 on migrant action for development through job creation, social entrepreneurship, and public policy advocacy also mentioned ensuring decent work in SMEs, ${ }^{25}$ thereby bridging an important gap regarding the employment practices of migrant enterprises and decent work.

In general, although the rights of irregular migrant workers and their families are highlighted in all of the documents, no special attention has been paid to the differences between informal employment practices in households or enterprises, whether belonging to migrants or natives. The labour needs of SMEs were rather neglected as the multinational corporations, the business representatives of Civil Society Days, dominated the agenda while presenting their good recruitment practices.

\section{Conclusion}

An analysis of the GFMD Government Days' documents reveals an enduring consistent focus on economic development through the remittances of migrants and diaspora. However, gradual progress can be seen towards developing a migrants' human rights perspective under the influence of representatives of migrant-sending peripheral countries and the interventions of civil society organizations advocating for migrants' rights. Although governments have tended to prioritize circular or temporary migration as an overall remedy and to stress the remittance capacity of migrants as an indicator of development, while ignoring the permanent need for low-skilled labour in receiving countries, they could not totally neglect the demands of civil society actors. Rights-based labour migration policies and the provision of decent work and social protection for all migrants, irrespective of their status, have been priority issues for civil society actors.

Comparing documents from the GFMD Government and Civil Society Days exposes similarities and differences in the diagnosis of problems related to irregular migration and informal employment, as well as in the recommendations for solving these problems. More specifically, both governments and civil society actors recommend labour market needs assessments, matching supply and demand through correct recruitment practices, and regular migration channels. Recommendations also include the ratification of conventions on migrant and labour rights, passing national laws to implement mechanisms protecting vulnerable migrant workers, including domestic workers and migrants in irregular status, and the adoption of a decent work agenda. Recently, there has been consideration of the difficulties faced by small migrant enterprises and the neglect of their specific labour force needs by official migration policies, which encourages the informal employment of irregular migrants. 
The root causes of migration, namely the uneven development that causes economic, social, and political problems forcing people into irregular migration, have not been a discussion theme in the Government Days. It is also clear that the overriding approach for governments is to accept neoliberal globalization without questioning it, as this would be to interrogate the policies shaped for the interests of global capital depriving people's chances for a decent life in many peripheral countries. Discussion in the Civil Society Days, on the other hand, has usually been deferred because of the urgency of developing concrete recommendations to improve the working and living conditions of irregular migrants in informal employment. Simultaneously, the deepening of a debate on root causes has not been possible because of the diverse nature and different interests of the constituents of civil society.

\section{Notes}

1. An interesting example of this situation compelling small employers to employ irregular migrants concerns farmers in Murcia, Spain. After a traffic accident in which 12 Ecuadorian irregular migrants were killed on their way to a farm, the government announced plans to combat the underground economy. However, farmers reacted by claiming that they were obliged to hire undocumented immigrants as they represented the only available labour force. Recognising this demand from 4000 farmers, the government approved a special regularisation plan that legalised 24,532 Ecuadorian migrant workers (Gonzalez-Enriquez, 2009, p. 17).

2. For a critical evaluation of the role of civil society in global migration governance, see other articles in this issue.

3. GFMD Operating Modalities, http://www.gfmd.org/process/operating-modalities

4. http://gfmdcivilsociety.org/about/general-information/

5. While documents of all the following GFMD meetings were examined, only the relevant ones are referred to in the following section.

6. Gonzalez-Enriquez (2009, p. 21).

7. Background Paper, Roundtable 1, Session 1.2, (Philippines contribution for RT1.2), p. 5.

8. Gonzalez-Enriquez (2009, p. 5).

9. Draft Concept Note, Turkey, 13-14 October 2011, p. 2.

10. Concept Note, San Salvador, 4-5 October 2011, pp. 2-3.

11. Draft Concept Note, Turkey, 13-14 October 2011.

12. Mexico GFMD 2010 Report of the Proceedings, pp. 23-24.

13. Summary Report for the GFMD, Jamaica, 7-8 September 2011, p. 4.

14. GFMD 2011 Concluding Debate, Geneva, 1-2 December 2011, Cluster I Summary Report, p. 11.

15. Session Rapporteur's Summary notes, p. 4.

16. Background Paper on Roundtable Session 3.2: 'Private sector-government partnerships to support migrant/diaspora entrepreneurship and job creation, with a focus on small and medium-sized enterprises', GFMD Turkey 2014-2015, p. 2.

17. No documents are available for the outcomes of Civil Society Days between 2007 and 2010 on the website of gfmdcivilsociety.org

18. Final Report Civil Society Days 2011, GFMD.

19. Final Report of the Civil Society Days Sweden had not been published on 3 December 2016.

20. Civil Society 'Stockholm Agenda' on migrant and migration-related goals and targets in post-2015 global and national development agendas.

21. Consolidated civil society feedback on 1st draft GFMD 2015 Concept Note (dated 2 October 2014).

22. GFMD Civil Society Recommendations, Benchmarks, Actions, GFMD Civil Society Days 2015, Turkey, p. 6.

23. Final Report - Civil Society Days Global Forum on Migration and Development, Mauritius 2012, p. 24.

24. Action Paper for Working Sessions 4.21: 'Diaspora and migrant action on job creation, social entrepreneurship and public policy'.

25. GFMD Civil Society Recommendations, Benchmarks, Actions, GFMD Civil Society Days 2015, Turkey, p. 9. 


\section{Acknowledgements}

I would like to thank the co-editors Raul Delgado Wise and Branka Likic-Brboric of this special issue as well as Carl-Ulrik Schierup for their invaluable comments on earlier drafts of this paper. I also thank the anonymous reviewers who contributed to the refinement of the paper with their suggestions.

\section{Disclosure statement}

No potential conflict of interest was reported by the author.

\section{Funding}

This article is a contribution to the Swedish Research Links project, 'Migration and development. What space for civil society in global governance? (MIGLINK)', with financial support through the Swedish Research Council [grant number 348-2013-6682].

\section{References}

Bangasser, P. E. (2000). The ILO and the informal sector: An institutional history. Geneva: Employment Sector ILO.

Betts, A. (2011). Global migration governance. Oxford: Oxford University Press.

Bloom, T. (2014). Extended report: Global migration governance: A decade of change. Barcelona: UNU-GCM. Brinkmeier, E. (2011). Illegality in everyday life: Polish workers in Dutch agriculture. In M. Bommes \& G. Sciortino (Eds.), Foggy social structures irregular migration, European labour markets and the welfare state (pp. 45-65). Amsterdam: Amsterdam University Press.

Carr, M., \& Chen, M. (2002). Globalization and the informal economy: How global trade and investment impact on the working poor. Geneva: Employment Sector ILO.

Castells, M., \& Portes, A. (1989). World underneath: The origins, dynamics and effects of the informal economy. In A. Portes, M. Castell, \& L. Benton (Eds.), The informal economy (pp. 11-37). London: The John Hopkins University Press.

Castles, S. (2015). Migration, precarious work, and rights: Historical and current perspectives. In C. U. Schierup, R. Munck, B. Likic-Brboric, \& A. Neergaard (Eds.), Migration, precarity \& global governance (pp. 46-67). Oxford: Oxford University Press.

Castles, S., Cubas, M. A., Kim, C., \& Özkul, D. (2012). Irregular migration: Causes, patterns, and strategies. In I. Omelaniuk (Ed.), Global perspectives on migration and development (pp. 117-151). New York, NY: IOMSpringer.

Castles, S., \& Miller, M. J. (2003). The age of migration (2nd ed.). New York, NY: Guilford Press.

Coffey, W. J. (1996). The 'newer' international division of labour. In W. Lever \& P. Daniels (Eds.), The global economy in transition (pp. 40-61). London: Longman.

Delgado Wise, R. (2009). Forced migration and US imperialism: The dialectic of migration and development. Critical Sociology, 35(6), 767-784.

Delgado Wise, R. (2013, February). The migration and labor question today. Monthly Review, pp. 25-38. 
Delgado Wise, R. (2018). Is there a space for counterhegemonic participation? Civil society in the global governance of migration. Globalizations, 15(6).

Delgado Wise, R., Covarrubias, H. M., \& Puentes, R. (2013). Reframing the debate on migration, development and human rights. Population, Space and Place, 19(4), 430-443.

EC-European Commission. (2009, 23 November). Clandestino project final report. Retrieved from http:// clandestino.eliamep.gr/category/projects-reports/final-report/

Ehrenreich, B., \& Hochschild, A. R. (2003). Global woman-nannies, maids and sex workers in the new economy. London: Granta Books.

Finotelli, C. (2011). Regularisation of immigrants in Southern Europe: What can be learned from Spain? In M. Bommes \& G. Sciortino (Eds.), Foggy social structures irregular migration, European labour markets and the welfare state (pp. 189-210). Amsterdam: Amsterdam University Press.

Gendera, S. (2011). Gaining an insight into Central European transnational care spaces: Migrant live-in care workers in Austria. In M. Bommes \& G. Sciortino (Eds.), Foggy social structures irregular migration, European labour markets and the welfare state (pp. 91-115). Amsterdam: Amsterdam University Press.

Gonzalez-Enriquez, C. (2009). Undocumented migration counting the uncountable. Data and trends across Europe. Clandestino Country Report Spain, European Commission. Retrieved from http://clandestino. eliamep.gr/category/irregular-migration-in-the-eu/country-reports/

Hussmanns, R. (2002). Defining and measuring informal employment. Geneva: ILO.

ILO. (2002). Decent work and the informal economy. Report VI. Geneva: Author.

ILO. (2013). Women and men in the informal economy: A statistical picture (2nd ed.). Geneva: ILO.

Jones, T., Monder, R., \& Edwards, P. (2007). Ethnic minority business and the employment of illegal immigrants. Entrepreneurship and Regional Development: An International Journal, 18(2), 133-150.

Kaşka, S. (2009). The new international migration and migrant women in Turkey: The case of Moldovan domestic workers. In A. İçduygu \& K. Kirişçi (Eds.), Land of diverse migrations (pp. 725-792). İstanbul: Bilgi University Press.

Kiely, R. (2008). Global shift: Industrialization and development. In V. Desai \& R. B. Potter (Eds.), The companion to development studies (pp. 183-186). London: Hodder Education.

King, R. (2000). Southern Europe in the changing global map of migration. In R. King, G. Lazaridis, \& C. G. Tsardanides (Eds.), Eldorado or fortress: Migration in Southern Europe (pp. 3-26). Basingstoke: Palgrave.

Kofman, E., Phizacklea, A., Raghuram, P., \& Sales, R. (2000). Gender and international migration in Europe. London: Routledge.

Lazaridis, G. (2007). Irregular migration and the trampoline effect: 'Les infirmières exclusives', 'quasi-nurses', nannies, maids and sex workers in Greece. In E. Berggren, B. Likic-Brboric, G. Toksöz, \& N. Trimikliniotis (Eds.), Irregular migration, informal labour and community: A challenge for Europe (pp. 242-254). Maastricht: Shaker Publishing.

Leonard, M. (2000). Coping strategies in developed and developing societies: The workings of the informal economy. Journal of International Development, 12(8), 1069-1085.

Likic-Brboric, B., \& Schierup, C. U. (2012). Asymmetric governance, labour standards, and migrants' rights. Norköpping: REMESO.

Lutz, H. (2007). 'The 'intimate others' - Migrant domestic workers in Europe. In E. Berggren, B. Likic-Brboric, G. Toksöz, \& N. Trimikliniotis (Eds.), Irregular migration, informal labour and community: A challenge for Europe (pp. 226-241). Maastricht: Shaker Publishing.

Maroukis, T. (2009). Undocumented migration, counting the uncountable. Data and trends across Europe. Clandestino Country Report Greece, European Commission. Retrieved from http://clandestino.eliamep. gr/category/irregular-migration-in-the-eu/country-reports/

Näre, L. (2011). The informal economy of paid domestic work: Ukrainian and Polish migrants in Naples. In M. Bommes \& G. Sciortino (Eds.), Foggy social structures irregular migration, European labour markets and the welfare state (pp. 67-87). Amsterdam: Amsterdam University Press.

Piore, M. J. (1979/2008). Birds of passage: Migrant labour and industrial societies. Cambridge: Cambridge University Press.

Reyneri, E. (1998). The role of the underground economy in irregular migration to Italy: Cause of effect. Journal of Ethnic and Migration Studies, 24(2), 313-331. 
Reyneri, E. (2002). Migrants' involvement in irregular employment in the Mediterranean countries of the European Union. Retrieved from www.ilo.int/wcmsp5/groups/public/---ed .../---migrant/.../wcms_ 201875.pdf

Reyneri, E. (2004). Immigrants in a segmented and often undeclared labour market. Journal of Modern Italian Studies, 9(1), 71-93.

Rother, S. (2011). Standing in the shadow of civil society? The 4th global forum on migration and development (GFMD) in Mexico. International Migration, 50(1), 179-188.

Rother, S. (2013). A tale of two tactics: Civil society and competing visions of global migration governance for below. In M. Geiger \& A. Pecoud (Eds.), Disciplining the transnational mobility of people (pp. 41-62). Basingstoke: Palgrave Macmillan.

Sassen, S. (1997). Informalization in advanced market economies. Issues in Development, Discussion Paper 20. Geneva: ILO.

Schierup, C. U., Alund, A., \& Likic-Brboric, B. (2014). Migration, precarization and the democratic deficit in global governance. International Migration, 53(3), 50-63.

Simonazzi, A. (2008). Care regimes and national employment models (Working Paper No.113). Rome: Universita Degli Studi Di Roma.

Slavnic, Z. (2010). Political economy of informalization. European Societies, 12(1), 3-23.

Standing, G. (2011). The precariat. New York, NY: Bloomsbury Academic.

Tokman, V. E. (1990). The informal sector in Latin America: Fifteen years later. In D. Turnham, B. Salome, \& A. Schwarz (Eds.), The informal sector revisited. Paris: OECD.

Tokman, V. E. (1992). Beyond regulation: The informal economy in Latin America. London: Lynnie Rienner Publishers.

Trimikliniotis, N., \& Fulias-Sourroulla, M. (2013). Informalisation and flexibilisation at work: The migrant woman precariat speaks. In A. Floya, M. Kontos, \& M. Morokvasic-Müller (Eds.), Paradoxes of integration: Female migrants in Europe (pp. 59-78). London: Springer.

Van Hear, N., \& Castles, S. (2011). 'Root causes'. In A. Betts (Ed.), Global migration governance (pp. 287-306). Oxford: Oxford University Press.

Veiga Martinez, U. (1999). Immigrants in the Spanish labour market. In M. Baldwin-Edwards \& J. Arango (Eds.), Immigrants and the informal economy in Southern Europe (pp. 105-128). London: Frank Cass.

Veiga Martinez, U. (2007). Irregular migration, informal labour and poverty in the agricultural sector in Spain. In E. Berggren, B. Likic-Brboric, G. Toksöz, \& N. Trimikliniotis (Eds.), Irregular migration, informal labour and community: A challenge for Europe (pp. 226-241). Maastricht: Shaker Publishing.

Woolfson, C., \& Likic-Brboric, B. (2008). Migrants and the unequal burdening of 'toxic' risk: Towards A new global governance regime. Debatte: Journal of Contemporary Central and Eastern Europe, 16(3), 291-308. 


\title{
Repoliticizing international migration narratives? Critical reflections on the Civil Society Days of the Global Forum on Migration and Development
}

\author{
Kellynn Wee, Kudakwashe P. Vanyoro and Zaheera Jinnah
}

\begin{abstract}
This paper draws on Pécoud's international migration narratives (IMN) as an analytical framework to examine the Global Forum on Migration and Development's Civil Society Days (GFMD-CSD). We analyse the narratives both produced and challenged at the GFMD-CSD, suggesting that while the GFMD-CSD poses a gentle challenge to existing IMN, it falls short of meaningfully (re)politicizing predominant migration paradigms. This is partly due to how the forum is a fraught space that reflects and reproduces uneven power dynamics between the Global North and South, concealing and nullifying contestations of power. Nonetheless, the GFMD-CSD, as a hybridized, experimental and fluidly defined discourse-led 'global' space, still functions as an important arena through which challenges to depoliticized state-led rhetoric might slowly trickle. Therefore, a closer interpretation of self-reflexive GFMD-CSD civil society strategies might challenge Pécoud's conceptualization of what constitutes a 'depoliticized' approach to migration.
\end{abstract}

\section{Introduction}

The Global Forum on Migration and Development (GFMD), in its very mandate, draws together the entwined themes of globalization and migration. The governance of international migration flows has become a key feature of global debates. In this present climate of wall-building and border-making, with the United States having just withdrawn from the Global Compact on Safe, Orderly, and Regular Migration ('US withdraws from UN Global Compact on Migration', 2017), understanding the place of migration globally is more pressing than ever before. In this paper, we use the GFMD's Civil Society Days (GFMD-CSD) as a starting point to understand how international migration narratives (IMN, Pécoud, 2015) are produced, challenged, and/or re/depoliticized at ostensibly 'global' spaces.

Existing scholarly literature has tended to focus on the GFMD in relation to the participation of nation-states and civil society in the global governance of migration (e.g. Rother, 2010), and has dealt with challenges to the GFMD-CSD by alternative civil society alliances (e.g. Castles, 2011; Rother, 2009a). The GFMD has been characterized as a space that allows states to foster informal partnerships (Rother, 2009b), and as productive of a 'softer' form of cooperation between stateand non-state actors (Kalm, 2010), rather than as a traditional norms- or standard-setting agency 
(Martin \& Abella, 2009). Analysis has also focused on the rhetoric of governments, non-government organizations (NGOs), and international organizations (IOs) by examining supranational discourse (Levatino \& Pecoud, 2012), discourse as a mode of legitimation (Korneev, 2017) and policy 'scripts' (Geiger \& Pécoud, 2014). Drawing from this rich disciplinary lineage, Pécoud (2015) argues that IOs trade in what he calls 'international migration narratives'. These present an idealized vision of the global governance of migration through a technocratic, depoliticized, and normalizing lens.

Through a focus on the GFMD-CSD as a loosely defined discourse-based platform - rather than as an IO, on which Pecoud focused - we seek to understand if this ever-evolving, informal, and fluidly defined space offers some potential for repoliticization. By doing so, we ask if Pécoud's vision of IMN as static and self-reproducing holds true when applied to 'hybrid' spaces that range beyond more conventional global governance and policy arenas. We suggest that non-binding discoursebased platforms such as the GFMD-CSD - and, by extension, the upcoming Global Compact on Safe, Orderly and Regular Migration - offer some openness for revisiting reproducible and static migration narratives without overstating the potential to politicize. We begin with a brief overview of the GFMD in the context of global migration governance. This is followed by the methodology employed. Thereafter, politicization, IMN, and key frameworks are presented before moving on to our main arguments. Finally, conclusions are offered.

\section{Global civil society: the GFMD in the context of global migration governance}

Contemporary civil society organizations have proven highly capable of working in the nascent global civil sphere, despite the absence of regional or global parliaments, party competitions, and elections (Clark, 2008). Bartelson (2006, p. 374) defines global civil society as 'a locus of resistance against global concentrations of wealth and power, as well as an alternative to the practices of power politics between or within states'. Meanwhile, Castells (2008, p. 78) defines it as 'the organized expression of the values and interests of society'. However, 'global civil society' as a concept is less coherent than it first appears, and its normative foundations are contested (Bartelson, 2006). Scholars argue that normative and descriptive representations of global civil society simultaneously describe a political project and a reality which does not necessarily reflect or live up to that project and its goals (Buckley, 2013; Kaldor, 2003).

In the global governance of migration, global civil society has created its own centres of power meant to resist global concentrations of wealth, which have for a long time gone unchallenged, by expressing and representing the values and interests of migrants in precarious positions. The global governance of migration - defined for the purpose of this article as the norms, regimes, and organizations that regulate states' responses to international migration (Betts, 2011) - has, until very recently, been criticized as piecemeal, fragmented, and uncoordinated (Grugel \& Piper, 2011; Kalm, 2010; Rother, 2009a, 2010). Many scholars argue that the destination countries have no interest in creating any kind of global institution to govern international migration (Kalm, 2010; Newland, 2012), partly because states are unwilling to relinquish sovereignty to a transborder authority (Abella, 2013; Pellerin, 2014). Debates on migration have been so polarized in international forums (Newland, 2012) that a recognition of migration as a policy field that transcends political borders has only flourished since the early 2000s (Bakewell, 2008; Grugel \& Piper, 2011; Nijenhuis \& Leung, 2017).

While the relationship between global civil society and governments is often troubled, one way in which migration has been pushed up the global agenda is through the 'hitching' of migration to the 
issue of development (Kalm, 2010; Rother, 2010). While this is a move that has come under fevered criticism (Bakewell, 2008; De Haas, 2005, 2010; Delgado Wise, Covarrubias, \& Puentes, 2013; Koppenberg, 2011; Nijenhuis \& Leung, 2017; Sriskandarajah, 2005), the GFMD is part of the global infrastructure that naturalizes the linkages between these issues.

This paper focuses specifically on the CSD within the GFMD. In 2015, 2016, and 2017, the GFMD consisted of three parts: Government Days, a yearly meeting between governments to discuss issues surrounding migration and development; the CSDs, constituting a meeting of representatives from global civil society towards the same end; and Common Space, intended to be an opportunity for civil society to raise their consolidated concerns to states. We recognize that the GFMD-CSD is constituted by very diverse organizations that make sense of globalization in different ways, and that it is by no means a homogenous entity (Clark, 2008) that actively bands together to seek to repoliticize IMN. However, mapping the IMN that are produced and circulated at the GFMD-CSD, and comparing them to the IMN identified by Pécoud allows us to understand if non-binding, discourse-led platforms are simply a 'toothless talking shop' or if they are 'influential in shaping debates' (Castles, 2011, p. 251). Examining the GFMD-CSD as a discourse-based platform rather than an IO therefore might yield insights into whether this format offers room for new norms to diffuse through predominant migration paradigms.

\section{Methodology}

This paper is grounded in the interpretive prism of qualitative research in which we attempt 'to make sense of actors' actions and language within their 'natural' setting' (Williams, 2000, p. 210). To understand the GFMD process, we carried out participant observations as delegates at consecutive GFMD-CSDs and Common Spaces from 2015 to 2017. Written accounts were kept in the form of minutes and notes describing our experiences, interactions, and observations. In 2017, one of the authors also attended the subsequent People's Global Action on Migration, Development and Human Rights (PGA), a parallel meeting which offered additional insights to civil society participants' relationship to the GFMD-CSD. To add value and contemporaneity to our analysis, subsequent to GFMD (2017), another author carefully followed regional consultations on the Global Compact on Migration, particularly in Africa.

Part of the analysis is also based on an examination of the corpus of GFMD-CSD reports and speeches from 2015 to 2017 to complement literature on the GFMD, which focuses mainly on the period between 2008 and 2014. These documents are all available for download from the GFMD-CSD online repository and include concept papers, action papers, plenary and working session reports, evaluations, recommendations, speeches and interviews with prominent actors. We focused our attention on the documents produced for and by the CSDs as well as for and by Common Space Day, as these were the GFMD forums that we were able to attend. We found that triangulating our experiences of these forums against the final, objectified reports gave us better scope to understand how they were constructed and produced. In total, we examined over 200 pages of documents.

Nevertheless, our methodological approach has some limitations. For example, as we were not able to gain access to the invitation-only Government Days, any analysis of these days would be confined to the grey literature produced. Therefore, as we were unable to triangulate these reports through our participation, we have omitted the Government Days from our analysis. We also limited our analysis to topics featured in plenaries and panels that we personally attended within the CSD and Common Space Day. Based on our research interests, these tended to focus on labour migration 
and recruitment reform, diaspora support and remittances, and xenophobia and the social perceptions of migrants.

\section{(De)politicization and the production of IMN}

Global platforms for dialogue are built on discourse, which we define in terms of its content, as a set of policy ideas and values, and in terms of its usage, as a process of interaction focused on policy formulation and communication' (Schmidt \& Radaelli, 2004, p. 184). The analysis of talk and text in policy has been variously tackled as 'storylines' (Drevet, 2005), 'policy discourses' (Vollmer, 2011), and 'scripts' (Geiger \& Pécoud, 2014). Drawing from nearly 10 years of work with UNESCO's migration programme, Antoine Pécoud expands on this to propose the notion of 'IMN', which he defines as 'the growing corpus of international reports and publications on migration, by and other international entities' $(2015$, p. 3). Having proliferated since 2000, IMN aim to 'produce a global and consensual discourse on a topic that is the object of bitter disagreements' (Pécoud, 2015, p. 4) and have evolved to encompass a fairly stable set of core arguments. This includes, for example, the linkage of migration to development, the framing of issues in the language of 'problems' and 'solutions', and the imagining of an 'ideal horizon' in which migration would contribute to the achievement of global peace and human rights. The question, Pécoud states, is whether understanding IMN can lead to a repoliticization in migration politics through the dismantling of tired myths and the introduction of new discourses.

For the purpose of our analysis, we suggest that politicization goes beyond the act of simply framing inequality as an issue of rights (Piper, 2013). Our expansion of this framework can be found in Cuttitta's (2017, p. 3) conceptualization of depoliticization as

... the tendency of political actors to obscure the political character of politics and to present policymaking as a neutral, necessary and indisputable process, in which the possibility to choose between different political (not merely technical) alternatives, as well as that for disagreement and contestation, is limited or denied.

Depoliticization is accompanied by 'rhetorical strategies employed by various social actors to either open up or close down the appearance of an issue as being political' (Wood, 2016, p. 524). Processes of depoliticization transform politics from vivid clashes and contestations to dull, technical discussions about means for promoting goals questioned by none (Cuttitta, 2017). Thus 'if depoliticizing means obscuring, repoliticizing means revealing and reviving the political (that is the plural and conflictual) character of politics' (Cuttitta, 2017, p. 4). We argue that repoliticization consequently entails actively demonstrating a critical awareness of the political character of policy decisions made by states in a manner that disrupts the continuation of power politics. Repoliticization thus is disruptive of the status quo that hegemonic states in the international system adopt. Therefore, rather than passively accepting the whole framework, it ought to be radical, conflictual, and antagonistic if it is to be in any way emancipatory and transformative (Cuttitta, 2017). There are many ways of framing and challenging inequalities that may reflect such a drive, and arguing for a rights-based discourse is only one way to do so.

According to Pécoud's analysis of over 3000 pages of migration reports, IMN have particular characteristics. Thematically, they focus on what powerful governments in destination countries, read here mainly to be OECD countries, are most concerned about (dialogue and cooperation, migrant integration, migration and development, temporary labour migration, irregular migration). Further, they tend to be repetitive and lack a sense of evolution, and they also show strong 
convergence on critical political questions, such as preferring 'managed migration' as a euphemistic 'third way' between the prospect of a borderless world and a situation of 'zero immigration', or upholding states' sovereign right to maintain their borders. The very notion of 'management' is apolitical and technocratic in nature (Cuttitta, 2017; Geiger \& Pécoud, 2010). Reports are produced anonymously with little sense of the relationships between actors and varying sets of ideas that tussle behind the scenes of every production; the 'shared vision' espoused by the final product tends to be the lowest common denominator of compromise, hence explaining the 'inward-looking' and depoliticized tendency to revert to a call for cooperation.

Pécoud also deconstructs IMN to show how they 'aspire at a double order' (2015, p. 92). What he means by this is that IMN first produce neat, orderly, and well-demarcated policy categories out of the messy, overlapping, and complicated realities of migration, and then prescribe recommendations that 'manage' migration in ways that are seen to be balanced and organized. The tendency of policy to produce problems and then proffer solutions is also noted elsewhere, particularly in work dealing with the discourse analysis of policy (Roldan \& Gasper, 2011). Pécoud (2015, pp. 92-93) writes that this:

... points to the deep relation between knowledge and power, as describing reality cannot be disassociated from the way in which one wishes to modify it. Yet, unlike other ideologically loaded political discourses, IMN do not acknowledge their normative efforts [...] What is therefore problematic with IMN is that they present both orders (analytical and political) as straightforward, whereas there are always different and plural ways of ordering and governing reality.

As such, through the 'double ordering' that Pécoud writes about, IMN continually depoliticize their topic through nullifying and redefining concepts which have radical potential, such as 'circulation', 'freedom', and 'civil society'. This allows for IMN to grapple with topics of migration without having to deal with a criticism of global structures upheld by nation-states such as neoliberalism, capitalism, classism, and patriarchy. IMN also depoliticize migration through adopting 'neithernorism' to absolve themselves of having to make a political position, and, behind the guise of 'dialogue' and 'debate', adopt the rule of arbiter rather than participant.

We note that changes in rhetoric do not necessarily indicate an actionable difference 'on the ground' (see also Schmidt \& Radaelli, 2004); to track the impact of discursive shifts on migration policy is beyond the scope of this paper. Nonetheless, in the absence of a supranational authority on migration, the shape of discourse, and the relation of the knowledge it federates to nascent webs of power, is a critical starting point (Levatino \& Pecoud, 2012). We thus move one step before the question of impact. We ask if the GFMD-CSD, as a loosely defined, rhetorically orientated, and hybrid conference-style space, has - in contrast to Pecoud's arguments - the potential to discursively repoliticize the core arguments of IMN. As a venue where IOs, NGOs, and other civil society actors struggle to build discursive consensus on issues of migration, how does the concerted production of knowledge at this particular venue serve as a legitimizing strategy for a diverse coalition of civil society participants (Korneev, 2017)? Does the GFMD-CSD - as a discourse-generating platform rather than an institution or organization - offer room for IMN to be challenged or is its potential to politicize nonetheless ultimately curtailed by its state-led nature and fragmented by the competing agendas of 'global' civil society?

\section{A space for IMN?}

Framed through the lens of IMN, the GFMD-CSD reports, proceedings, and speeches at first glance share many common characteristics with the core arguments of conventional IMN. To begin with, 
the relationship between migration and development is usually framed as mutually beneficial and iteratively reinforcing, and the assumptions that undergird this relationship generally go unquestioned in official rhetoric, even though the intertwining of 'migration' and 'development' has troubling implications that strike at the heart of the ideas underpinning the global governance of migration (see e.g. Bakewell, 2008; Delgado Wise et al., 2013; Eisele, 2012; Martin \& Abella, 2009). Civil society participants at the GFMD-CSD are cognizant of the political currency of the 'migration and development' discourse prevalent in its programmes, debates, and reports, and are well aware that adhering to its core arguments generates political currency with governments (Rother, 2010); that is, 'development' still serves as a 'fig leaf that allows the international community to address in a multilateral setting the perennially touchy subject of international migration' (Chikezie, 2012, p. 212). As such, the typical migrant addressed in the GFMD-CSD discussions is a labour migrant (Koppenberg, 2011), which suits the economistic approach to migration favoured by states while eschewing more difficult questions about migrants beyond markets. For example, the focus of the 2017 GFMD-CSD was on the Global Compact on Migration, and the deliberations thereof mainly addressed issues of better regulating labour migration for win-win-win (Martin \& Abella, 2009) developmental outcomes. However, refugees were visibly excluded from the Global Compact on Migration discussions and their concerns were regarded as falling within the United Nations High Commissioner for Refugees (UNHCR) mandate in the Global Compact on Refugees. This is consistent with IMN's desire to produce neat, orderly, and well-demarcated policy categories.

In accordance with IMN, migration is framed as occurring because the 'root causes' of development have been inadequately addressed. In a 2015 GFMD report, one of the recommendations on 'transit, crisis, and forced migration' called upon governments to 'do much more to address the root causes of forced migration, including addressing environmental degradation and climate change, the lack of livelihoods and decent work, and conflict and human rights abuses in countries and regions of origin' (Migration and Development Civil Society (MADE) Network, 2015a, p. 6). This position was also echoed in the 2016 GFMD in Dhaka, where a final report called for the 'root causes of [...] displacement' to be addressed through investing in social, economic, and infrastructural support, and in recommendation 10 of Wies Maas' 2017 report (see MADE Network, 2017c, p. 4). This positioning supports the depoliticized narrative that preventing or 'better regulating' South-North migration through supporting initiatives such as strengthening local livelihoods and providing decent work will minimize both 'forced' and 'voluntary' (economic) migration flows (see Bakewell, 2008). Development aid is hence often 'instrumentalized' for the regulation of migration flows with the ultimate goal to prevent or arrest migration within and out of the continent (see Landau, 2017; Matsas, 2008). In many ways, the GFMD-CSD's positioning suited the EU's 'sedentary bias' (Bakewell, 2008; Castles, 2010) by accentuating a discourse of 'containment development', 'a form of 'imperialist externalization by re-inscribing power relations between Europe and its former African colonies' (Landau, 2017, p. 8).

The GFMD-CSD reports also align themselves with the underlying assumptions built into ostensibly 'neutral' keywords within the global governance vocabulary. For example, 'safe, orderly, and regular' migration is framed as a desirable goal in the GFMD-CSD 2016s concept paper (MADE Network, 2016a), specifically in alignment with other major global governance mechanisms such as the New York Declaration, the sustainable development goals (SDGs), and the formulation of the Global Compact on Migration. This emphasis on 'safe, orderly, and regular' migration was further heightened in the 2017 GFMD-CSD, which urgently framed it as a key opportunity for civil society participants to come to a broad consensus about migration-related issues so that specific inputs can be made into the Global Compact on Migration. The theme for GFMD-CSD 2017, for instance, urged 
not only an unchallenged acquiescence with 'safe, orderly, regular migration' but demanded it now as 'mechanics of a compact worth agreeing to' (MADE Network, 2017a). It was not the existence of the Compact itself that came under significant critical scrutiny. Rather, the question that drove the proceedings of the GFMD-CSD 2017 was how best to influence the Compact, not if it was an adequate, ideal, or appropriate global governance framework. Any radical challenge to predominant global governance measures was not to be found, at least in the GFMD's formal rhetoric, and the desire to falsely differentiate flows of migrants into distinct policy problems and the subsequent political prescription to 'manage' them, a key feature of depoliticized IMN (Pécoud, 2015), remained unquestioned in the 2017 GFMD-CSD.

A closer examination however - particularly when delving into the corpus of reports beyond the key speeches and documents - yields the realization that the GMFD-CSD exhibits self-consciousness about conventional IMN narratives. There are symbolic shifts in the language and framing of the reports which are especially noteworthy, signalling a desire to lean away from - although not entirely dispense with - a depoliticized approach to migration. For example, in the GFMD-CSD 2016 reports, there is a concerted attempt to move towards accountability and implementation instead of resorting to generally depoliticized principles or promises. The word 'implement', for example, appears in the four-page principal recommendations a total of eight times and is even italicized four times for additional emphasis. Its reiteration and italicization signify a metatextual self-consciousness in engaging with conventional IMN, and this self-consciousness is also amplified through an explicit in-text observation that signals the author(s)' exasperation with existing IMN framings, and a desire to move the Global Compact beyond them:

On governance: To ensure the Global Compact for Safe, Orderly and Regular Migration is a multilateral, rights-based framework that, rather than simply re-stating existing rights or principles, more mechanically focuses on tools, cooperation and systems that implement those rights and principles. As in the SDGs, the Compact should consider a structure of clear goals, targets and indicators on a graduated timeline that fosters policy coherence, real achievement and genuine accountability. (MADE Network, 2016b, p. 3)

By paying attention to reports which are less likely to be perused by the general public, such as GFMD-CSD session-specific documents as well as templates for rapporteurs' final reports (see MADE Network, 2017b), we can see a desire - almost even an impatience - to move towards a commitment to action, marked by a timeline and structured by monitoring indicators. By doing so, the above-mentioned organizers try to pre-empt, channel, and reflect civil society delegates' sense of frustration with the lack of a coherent and actionable global governance framework. The rapporteurs, for example, moved away from taking conventional minutes and moved towards using a template that requested not just recommendations but also targeted actors responsible for suggested changes, recommended specific actions that could be taken, requested indicators of success and illustrated with examples of systemic disruptions and concrete practices that civil society delegates thought effective. Women and children rapporteurs were appointed and crosscutting themes emphasized in order to move away from the categorizing impulse and 'double ordering' of IMN (Pécoud, 2015). The word 'doing' was carefully incorporated (and emphasized through italics) into the session title of almost every plenary and working session. This focus was amplified in Wies Maas's Common Space speech in 2017 as civil society chair, where her first point was explicitly about 'implementing [commitments to human rights], not simply restating them' (MADE Network, 2017c, p. 2). This might be read as enfolding an implicit critique of the nature of the GFMD and cautioning against its replication in the upcoming Global Compact. 
By accentuating 'goals, timelines, and means for implementation that are ambitious, achievable, and accountable' (see MADE Network, 2017c, p. 2), and being partially open to the ideal possibility of a binding Compact, it is possible to read this as GFMD's civil society pedagogically modelling the global governance framework that it wants to see in the world. It is true, however, that the GFMDCSD reports and resolutions ultimately do not represent a brave new world of radical political challenge. For instance, the 'silent' position to leave it at a non-binding Global Compact and the subsequent reports continue to locate their critiques in normative paradigms and existing norms of soft multilateral cooperation. To this end, the narratives of the GFMD-CSD push and provoke, but do not revolutionize.

In our subsequent observations at the 2017 GFMD-CSD, 'safe, orderly, and regular' migration was largely accepted by civil society participants as a desirable mandate, with a selective focus on 'safe' and 'regular' while eliding the troubling implications of 'orderly'. The notion that 'safe' migration may, at times, contradict what states view as 'regular' or 'orderly' migration was mentioned in debates, but not strongly reflected in the ultimate recommendations to governments, even though this critique fundamentally dismantles the dominant principles of 'safe, orderly, and regular' migration that guide future global governance agreements. In contrast, within concurrent forums such as the PGA 2017, participants fiercely criticized the 'migration management' model inherent in this policy goal, opening by asking 'safe, orderly, and regular migration for whom?' Also, in contrast, subsequent regional consultations in Africa on the Global Compact have worked to expunge this vocabulary (see e.g. the Bamako Report, 2017, p. 5).

\section{Concealed contestations at the GFMD}

Examining the interplay between the GFMD-CSD processes and its reports reveals splinters in the 'shared framework' that holds IMN together (Pécoud, 2015, p. 23). At the 2015 GFMD-CSD in Istanbul, there were 339 participants, 225 of which were from civil society (MADE Network, 2015b). More than one out of three civil society delegates led or presented in plenary and working sessions (86 of 225) (MADE Network, 2015b). Although the panel representation was geographically skewed to the Global North, we observed that it was still sufficient to allow civil society delegates to express their concerns, and the reports also led us to believe so. However, our participation demonstrates that representation at the forum did not always guarantee that all the critical issues presented by discussants or debated by the audience were taken up on the agenda of recommendations and action points that were reported to governments. In general, recommendations were necessarily limited due to the constraints of form, but, through discretionary under-reporting, the more provocative questions raised during discussions are often nullified and are hence not successful in nudging the paradigm far from previous GFMD-CSDs. Pécoud (2015, p. 24) perceives this tendency as the 'repetition of the same ideas, without any "real world" impact, fuelling a self-perpetuating "migration debate industry" that creates opportunities for participants who then have no interest in stopping the process'.

This observation is not peculiar to the 2015 GFMD-CSDs. In 2010, Rother wrote about the widespread complaints made by participants that the more progressive demands and suggestions from the workshops were missing from the summaries presented. Moreover, he reported, 'in terms of the level of migrant agency in the process, it has to be noted that the CSD participants only had indirect influence on the final recommendations. These were not presented to the delegates and voted upon, for example' (Rother, 2010, p. 164). 
Why then does the GFMD-CSD only offer such a 'gentle challenge' to predominant IMN as we have argued? We suggest that this is because discussions are nullified by existing dynamics of power within the process of the forum, which is a space freighted by topical priorities, uneven representations, and funding flows. The notion of the 'global' in the GFMD-CSD is, unsurprisingly, a conceit: as much as chairs, discussants, and participants attempted to address region-specific issues and perspectives in order to mitigate an Anglo-centric approach, the space is not a neutral one. At the GFMD-CSD 2015, for example, we noted that civil society representatives, particularly those from the Global South, spent a great deal of time offering contextual information about their own work when offering input, because the assumption was that the primary civil society and government audiences were from the Global North. This rhetorical performance is compounded by the urgency that some civil society delegates feel in wanting to advance marginalized agendas, especially when speaking about topics that might not fit in with mainstream IMN concerns; that is, participants unfamiliar with issues in Asia, Africa, and South America, and an agenda that foregrounds the concerns of the Global North. Pécoud, in analysing the most frequently discussed topics in IMN, notes that 'dialogue, cooperation, partnerships, and capacity building', 'integration', and 'migration and development, diasporas, skilled migration, and remittances' were the topics most highly prioritized, while migration, the environment, and internally displaced people - mainly issues that concern activists in countries within the Global South - ranked amongst the lowest. This means that Global South participants had to put in significant invisible work to grapple with imagined (and real) topical priorities, resulting in contributions located in specific contextual cases. Without the moderation necessary to make sense of these case studies by drawing middle-range regional factors together, and without the mandate to use these case studies as a way of unseating fundamental paradigms built into the migration management and migration and development frameworks, GFMD-CSD proceedings occasionally run the risk of turning into a series of disconnected monologues that remain lost in broader structural critiques. This follows a comment made by Pécoud (2015) which sees IMN as functioning at the level of the abstract or the level of the concrete, with little analytical focus on the in-between.

Funding flows and the geographical location of the GFMD-CSD powerfully shape the regional representation of civil society delegates. In 2016, when the forum was held in Dhaka, 39\% of the civil society delegates were from the Asia-Pacific region, 20\% from Europe, 17.5\% from Africa, $17.5 \%$ from the Americas, and 6\% from the Middle East (MADE Network, 2016b). In the 2017 GFMD-CSD in Berlin, percentages were weighted strongly towards delegates from Europe with $39 \%$ of the participants (including observers) residing in Europe, 16\% from Africa, 18\% from the Asia-Pacific region, 18\% from the Americas, and 5\% from the Middle East (MADE Network, $2017 \mathrm{~d}$ ). If the location of the forums was rotated equitably throughout various regions across the world, then delegates from the Global South might be able to participate on fairer footing. However, since the inception of GFMD-CSD, 6 out of 10 forums have been held in Europe (Belgium 2007, Greece 2009, Switzerland 2011, Sweden 2014, Turkey 2016, and Germany 2017). Asia has hosted it twice (the Philippines 2008 and Bangladesh 2016), the Americas once (Mexico 2010) and Africa (Mauritius 2012) once.

Peering more closely at the breakdown of participants within regions, and not just across them, reveals additional silences. The absence of civil society participants from major Asian countries of destination - such as Singapore (one participant: the first author, who is an academic participant), Taiwan (no participants), Korea (one participant), and Japan (one participant) - at the GFMD-CSD 2017 was also notable (MADE Network, 2017d). The Middle East, despite hosting hundreds of thousands of migrant workers from South Asia, is poorly represented. One participant at the GFMD-CSD 
2017 eloquently expressed his dismay at the almost complete silence on the Middle East's trade ban on Qatar and its effect on the hundreds of thousands of Bangladeshi migrant workers currently working in that country.

It is arguable that sheer numbers do not represent the influence of specific individuals from particular regions and their ability to set agendas at the GFMD-CSDs, but moving away from a broader snapshot to micro-interactions also reveals that activists at the GFMD-CSD, particularly from the Global South, find themselves constantly needing to 'broker' their agenda according to IMN conventions in order to ensure continued funding for and attention to their cause. One of the authors had a conversation with a member of an international women's rights group on this topic. She spoke about the difficulties she faced while acting as a 'development broker' (Lewis \& Mosse, 2006) between grassroots-level, local-led initiatives in South Asia and funders from the North. In order to make advocacy work visible, she had to 'translate' the activities performed into the annual reports and formal indicators required by her funders. This necessitates a two-way vernacularization of local realities to global discourses (Levitt \& Merry, 2009) and hints at the pressures to 'perform advocacy' at the GFMD-CSD in a specific way to suit global framings and IMN; a strategy required to secure legitimacy, funding, and the space to speak. Therefore, global power dynamics and flows of funding tend to compel activists - particularly activists from the Global South - to replicate and perpetuate IMN narratives instead of challenging them.

The GFMD-CSD, similar to many other international forums, is not a neutral space. It attempts to remedy power discrepancies in many ways. For example, through the introduction of children and women rapporteurs (notably, the GFMD-CSD 2017 introduced Milena Franke, a child rapporteur who was herself under 18 [GFMD Civil Society, 2017]), through ensuring the ready availability of translators, and through attempting to ensure region-specific representation and leadership on panels and plenaries. Nonetheless, the very unevenness of the 'back stage' of a global forum blunts challenges to dominant IMN that might potentially be brought to bear.

\section{In conclusion: whither (re)politicization?}

The strength of the GFMD is, as many have pointed out, precisely in its informal nature, which has drawn governments to the table when the spectre of binding commitments has not (Rother, 2009b). After 10 iterations of GFMD, its mandate has evolved beyond offering a platform for partners to build good relations, and the GFMD-CSD has clearly come far. The question to ask, then, may be: How much further can it (or should it) go?

For now, it seems that any radical reframing of the IMN that characterize GFMD-CSD - such as challenging the relationship between migration and development, querying the implications of 'safe, orderly, and regular migration', underscoring binding commitments and the critique of a 'root causes' approach - will have to take place elsewhere, even as GFMD-CSD participants level subtler criticisms at governments and governance within the confines of the rhetorical boundaries of the stated agenda. For more skewering dissections of the global governance endeavour, the PGA has historically been the place, not the GFMD-CSD. This does not mean that the GFMD-CSD is politically inert or lacks the ability to effect changes. The GFMD-CSD's 'silent' position to leave the Global Compact at a non-binding agreement represents a political strategy that arises from the realization that most receiving states have been reluctant to ratify conventions (e.g. only 49 states have ratified the International Convention on the Rights of Migrant Workers and Members of their Families). Rother (2009a) has also written about some of the strategies undertaken by civil society activists, who are well aware that many of their colleagues perceive the GFMD-CSD to be an example of global 
governance co-optation of civil society. Some members of civil society choose to adopt an 'insideroutsider' position, participating in the PGA, International Migrants Alliance (IAMR), and the GFMD-CSD; others choose to exclude themselves from the GFMD-CSD process entirely. Essentially, we can choose to see the GFMD-CSD's institutional buy-in to global governance measures as not only a constraint but also as an opportunity - and as something that can be leveraged on.

A second way of approaching the issue is to recognize the changing role of the GFMD-CSD, following the logic of the 'insider-outsiders', to argue that its 'gentle challenge' to IMN is highly strategic. The dual role that many GMFD-CSD 'insider-outsider' participants play may mean that civil society activists have decided that the divisions between subtly challenging and completely overturning IMN is worth preserving in order to ensure that civil society continues to have a seat at the global governance table. For example, particularly in the light of the laser focus which the latest iteration of the GFMD-CSD had on the formulation of the upcoming Global Compact, the discourse-based GFMD-CSD seems to have taken on the responsibility of building a 'highway' to discussions that might otherwise be limited to UN agencies and governments. The success of its intervention into the Global Compact is yet to be seen, but gauging from GFMD 2017, governments are willing to listen to CSD delegates. Nevertheless, one can ask: Is politicization revolutionary, or is it a slow drip - or, possibly, both? If, as this suggests, we adopt a more nuanced perspective of what depoliticization and repoliticization mean, then it is also possible to suggest that Pecoud's view of 'depoliticized' IMN may be too quick to discount self-reflexive global civil society organization and strategizing?

We conclude, therefore, with the hope that this paper's analysis of the GFMD-CSD rhetoric and processes offers a starting point for scholars to further interrogate the GFMD-CSD's civil society strategies by posing the following questions as baselines for future discussion. Do the same activists plan both participation and protest? How does civil society - which mobilizes on the basis of consensus - deal with discursive schisms, however, performative, across venues and spaces? And, ultimately, the perennial question that all social movement scholars ask: How does change, on a global level, take place? Perhaps reimagining the GFMD-CSD as a space for contestation, opposition, and politicization is one start to this discussion.

\section{Disclosure statement}

No potential conflict of interest was reported by the authors.

\section{Funding}

This work has been funded by UK Aid from the UK government through the Migrating out of Poverty Research Programme Consortium; however, the views expressed do not necessarily reflect the UK government's official policies. 


\section{References}

Abella, M. I. (2013). Multilateral approaches to managing migration. In I. Ness (Ed.), The encyclopedia of global human migration. Retrieved from http://arefiles.ucdavis.edu/uploads/filer_public/2014/11/04/abellamultilateral-approaches-to-managing-migration.pdf

Africa Civil Society Organizations Regional Consultation on the Global Compact on Safe, Orderly and Regular Migration (September, 2017). Bamako, 28-29 August 2017 Report (Circulated via email).

Bakewell, O. (2008). 'Keeping them in their place': The ambivalent relationship between development and migration in Africa. Third World Quarterly, 29(7), 1341-1358.

Bartelson, J. (2006). Making sense of global civil society. European Journal of International Relations, 12, 371-395. Betts, A. (2011). Global migration governance. Oxford: Oxford University Press.

Buckley, K. (2013). Global civil society: The dialectics of concept and reality. Globalizations, 10(2), 231-244.

Castells, M. (2008). The new public sphere: Global civil society, communication networks, and global governance. The ANNALS of the American Academy of Political and Social Science, 616, 78-93.

Castles, S. (2010). Development and migration - migration and development: What comes first? Global perspective and African experiences. Theoria: A Journal of Social and Political Theory, 56(121), 1-31.

Castles, S. (2011). Bringing human rights into the migration and development debate. Global Policy, 2(3), 248-258.

Chikezie, C. E. (2012). Civil society, the common space, and the GFMD. In I. Omelaniuk (Ed.), Global perspectives on migration and development: GFMD Puerto Vallarta and Beyond (pp. 207-226). New York: Springer.

Clark, J. D. (2008). The globalization of civil society. In J. W. S. G. Walker \& A. S. Thompson (Eds.), Critical mass: The emergence of global civil society (pp. 3-23). Waterloo: Wilfrid Laurier University Press.

Cuttitta, P. (2017). Repoliticization through search and rescue? Humanitarian NGOs and migration management in the central Mediterranean. Geopolitics, 1-29.

De Haas, H. (2005). International migration, remittances and development: Myths and facts. Third World Quarterly, 26(8), 1269-1284. Retrieved from http://www.jstor.org/stable/4017714

De Haas, H. (2010). Migration and development: A theoretical perspective. International Migration Review, 44 (1), 227-264.

Delgado Wise, R., Covarrubias, H. M., \& Puentes, R. (2013). Reframing the debate on migration, development and human rights. Population, Space and Place, 19, 430-443.

Drevet, T. (2005). Broken storylines: How the economics of flexibility is affecting international migration discourse (Unpublished doctoral dissertation). Rice University, Houston, TX.

Eisele, K. (2012). Reinforcing migrants' rights? The EU's migration and development policy under review. Global Justice: Theory Practice Rhetoric, 5, 31-45.

Geiger, M., \& Pécoud, A. (2010). The politics of international migration management. Basingstoke: Palgrave Macmillan.

Geiger, M., \& Pécoud, A. (2014). International organisations and the politics of migration. Journal of Ethnic and Migration Studies, 40(6), 865-887.

GFMD Business Mechanism. (2017). About Us. Retrieved from http://gfmdbusinessmechanism.org/home-2/

GFMD Civil Society. (2017, June 30). "I'm not alone: Over 50 million children in the world are migrants!" Milena Franke, our Children Rapporteur, is the first ever civil society delegate under 18. Read her intervention at the Global Forum on Migration and Development Common Space today! [Facebook post]. Retrieved from https://www.facebook.com/gfmdcsd/posts/1312089032237484

Grugel, J., \& Piper, N. (2011). Global governance, economic migration and the difficulties of social activism. International Sociology, 26(4), 435-454.

Kaldor, M. (2003). Global civil society: An answer to War. Cambridge: Polity.

Kalm, S. (2010). Limits to transnational participation: The global governance of migration. In C. Jönsson, \& G. Tallberg (Eds.), Transnational actors in global governance: Patterns, explanations, and implications (pp. 134154). New York, NY: Palgrave MacMillan.

Korneev, O. (2017). Self-legitimation through knowledge production partnerships: International Organization for Migration in Central Asia. Journal of Ethnic and Migration Studies. doi:10.1080/1369183X.2017.1354057 
Koppenberg, S. (2011). Dominant perspectives in the global level dialogue on migration and development. Retrieved from http://dev.migration4development.org.630elmp01.blackmesh.com/sites/default/files/ saskia_koppenberg_paper.pdf

Landau, L.B. (2017, March 16-17). The containment chronotrope: The European refugee 'crisis' and shifting sovereignties in sub-Saharan Africa. Paper presented at the Provocations of Contemporary Refugee Migration, FL.

Levatino, A., \& Pécoud, A. (2012). Overcoming the ethical dilemmas of skilled migration? An analysis of international narratives on the "brain drain". American Behavioral Scientist, 56(9), 1258-1276.

Levitt, P., \& Merry, S. (2009). Vernacularization on the ground: Local uses of global women's rights in Peru, China, India and the United States. Global Networks, 9(4), 441-461.

Lewis, D., \& Mosse, D. (2006). Development brokers and translators: The ethnography of aid and agencies. Bloomfield, CT: Kumarian Press.

MADE Network. (2015a). Achieving migration and development goals: Movement together on global solutions and local action. Recommendations, benchmarks, actions. Retrieved from http://www.madenetwork.org/ sites/default/files/background-documents/GFMD-2015-Recommendations-booklet-EN-1.pdf

MADE Network. (2015b, August 13). Concept paper and draft programme. Retrieved from http:// madenetwork.org/sites/default/files/background-documents/Concept-note-GFMD-CSD-2015-13-Aug_ background-info-ONLY_web.pdf

MADE Network. (2016a). Final concept paper and provisional programme of Civil Society Days 2016. Retrieved from http://madenetwork.org/sites/default/files/Concept20Paper20GFMD20201620Civil20Society20progra mme_finalEN_0.pdf

MADE Network. (2016b). Highlights and principal recommendations of the GFMD Civil Society Programme 2016. Retrieved from http://madenetwork.org/sites/default/files/GFMD20CSD20201620Highlights20and 20principal20recommendations-final.pdf

MADE Network. (2017a). Civil Society Days GFMD 2017. Retrieved from http://www.madenetwork.org/civilsociety-days-2017

MADE Network. (2017b). Documents, MADE Network. Retrieved from http://madenetwork.org/documents

MADE Network. (2017c, June 29). Report GFMD Civil Society Day 1 (29 June), by Wies Maas, Chair Civil Society Days 2017. Retrieved from http://madenetwork.org/sites/default/files/Common\%20Space\% 20speech\%20GFMD\%202017\%20-\%20civil\%20society_W.Maas_check\%20against\%20delivery.pdf

MADE Network. (2017d, June 24). DRAFT - List of registered participants. Retrieved from http://madenetwork. org/sites/default/files/List20of20registered20Participants20201720GFMD20CSD202420June.pdf

Martin, P., \& Abella, A. (2009). Migration and development: The elusive link at the GFMD. International Migration Review, 43(2), 431-439.

Matsas, R. (2008, June 5-7). The global forum on migration and development: A new path for global governance? Paper presented at the 2008 ACUNS annual meeting, The United Nations and Global Development Architecture, Bonn, Germany.

Newland, K. (2012). The GFMD and the governance of international migration. In I. Omelaniuk (Ed.), Global perspectives on migration and development: GFMD Puerto Vallarta and Beyond (pp. 227-240). New York: Springer.

Nijenhuis, G., \& Leung, M. (2017). Rethinking migration in the 2030 agenda: Towards a de-territorialized conceptualization of development. Forum for Development Studies, 44(1), 51-68.

Pécoud, A. (2015). Depoliticising migrations: Global governance and international migration narratives. London: Palgrave MacMillan.

Pellerin, H. (2014). On governance of migration management at the world level: Lessons and challenges. In S. Baglay \& D. Nakache (Eds.), Immigration regulation in federal states (pp. 39-59). Dordrecht: Springer.

People's Global Action. (2017). Power, people and policies: A critical moment for the future of migrant rightsProgramme. Retrieved from http://peoplesglobalaction.org/wp-content/uploads/2017/05/PGAProgramBE RLIN-FINAL.pdf

Piper, N. (2013). Resisting inequality: The rise of global migrant rights activism. In T. Bastia (Ed.), Migration and inequality (pp. 46-62). New York, NY: Routledge.

Roldan, B., \& Gasper, D. (2011). The Global Forum on Migration and Development: 'All talk and no action' or 'a chance to frame the issues in a way that allows you to move forward together'? In T.-D. Truong \& D. Gasper (Eds.), Transnational migration and human security (pp. 239-256). Berlin: Springer-Verlag. 
Rother, S. (2009a). 'Inside-outside' or 'outsiders by choice'? Civil society strategies towards the 2nd Global Forum on Migration and Development (GFMD) in Manila. ASIEN, 111, 95-107.

Rother, S. (2009b, July 9). The allure of non-binding talks. Retrieved from https://www.dandc.eu/en/article/ global-forum-migration-and-development-benefits-non-binding-setting

Rother, S. (2010). The GFMD from Manila to Athens: One step forward, one step back? Asian and Pacific Migration Journal, 19(1), 157-173.

Schmidt, V. A., \& Radaelli, C. (2004). Policy change and discourse in Europe: Conceptual and methodological issues. West European Politics, 27(2), 183-210.

Sriskandarajah, D. (2005). Migration and development: A new research and policy agenda. World Economics, 6 (2), 1-6.

US withdraws from UN Global Compact on Migration (2017, Dec 4). Al-Jazeera. Retrieved from http://www. aljazeera.com/news/2017/12/withdraws-global-compact-migration-171203160804853.html

Vollmer, B. (2011). Policy discourses on irregular migration in the EU - 'number games' and 'political games'. European Journal of Migration and Law, 13, 317-339.

Williams, M. (2000). Interpretivism and generalisation. Sociology, 34(2), 209-224.

Wood, M. (2016). Politicisation, depoliticisation and anti-politics: Towards a multilevel research agenda. Political Studies Review, 14(4), 521-533. 


\title{
Making or unmaking a movement? Challenges for civic activism in the global governance of migration
}

\author{
Aleksandra Ålund and Carl-Ulrik Schierup
}

\begin{abstract}
This article discusses dilemmas of global civic activism from a neo-Gramscian perspective as both subordinated and a potential challenge to hegemonic neoliberal order. With the investigational focus on the People's Global Action on Migration, Development and Human Rights (PGA) event, the space for civic activism relating to the intergovernmental Global Forum on Migration and Development (GFMD) and its associated Civil Society Days and Common Space is analysed. The article asks how the future of PGA activism may be influenced by its formalized representation within the GFMD. It posits that the PGA has landed at a crossroad between becoming a global activist counterhegemonic movement to a dominant neoliberal migration policy and being captured in a tokenist subordinated inclusion within a truncated 'invited space' for interchange. This ambiguous position jeopardizes its impact on global migration governance, discussed with reference to theories of transversal politics and issues of counterhegemonic alliance-building.
\end{abstract}

\section{Introduction}

At the centre of this paper are emergent civil society movements concerned with migrant's rights, and the political economy of neoliberal globalization. They question the precarisation of work and citizenship as well as dominant refugee and asylum politics. Such issues have since long been the object of critical research on civic activism and social movements.

Towards the end of the 1980s, Hall (1987) initiated a discussion of the relevance of Gramscian thought for understanding and acting politically in a profoundly transformed present. We live today, he observed, 'in an era when the old political identities are collapsing', raising questions on new political forms and a new cultural order. A new order emerges with a 'multiplicity of dispersed wills', 'heterogeneous aims', a 'pluralisation of modern cultural identities', and multiple centres of power (Hall, 1987, p. 20). The problem faced, Hall argued, is related to the capability of addressing this diversity of identities and social forces, unifying them within a common project across their differences. That means understanding - from an overall Gramscian perspective - civil society as an arena for mobilization, with contemporary social movements as a new political subject, subordinated to while also challenging neoliberal hegemony making.

Contemporary civil society organizations (CSOs) and movements demonstrate new forms of political participation, putting into question the growing democratic deficit of formal politics as well as

This is an Open Access article distributed under the terms of the Creative Commons Attribution License (http://creativecommons.org/licenses/by/4.0/), which permits unrestricted use, distribution, and reproduction in any medium, provided the original work is properly cited. 
'partnerships' between state, market, and civil society (Ålund, Schierup, \& Neergaard, 2017). Inclusion through 'integrative' co-optation may mediate change but may, at the same time, defuse counterhegemonic discourses and activism of contending movements through appropriative consensus-making (Coy \& Hedeen, 2007 [2005]), carrying 'uncertain futures for democratic possibilities' (Walton \& Udayagiri, 2003, p. 309). From this vantage point, this paper aims to contribute to the critical theoretical discussion of what we, with Purcell (2009a, p. 291), call counterhegemonic movements - that is, 'movements that can both undermine the dominance of neoliberalism and construct concrete alternatives to it' (Walton \& Udayagiri, 2003).

Grounded in a neo-Gramscian approach (Gill, 2003), we see our present historical moment as tendentially 'non-hegemonic' (Cox, 1983; Deak, 2005). This signifies more specifically an ostensibly hegemonic neoliberal 'end of history' in crisis challenged by cycles of contending movements (Funke, 2014). Yet, a morbid 'arrest of time' (Brown, 2005, p. 7) in the hiatus of which the new to be born can only be glimpsed through a looking glass darkly. Following Purcell (2009b, pp. 143-144), we discuss how unstable articulations of neoliberal hegemony mired in contradictions and legitimacy problems are challenged by counterhegemonic projects carried forth by movements of civil society; '[c] ounter-projects' that are not only 'possible', but indeed 'inevitable'. This posits social movement issues and prospects, Purcell (2009a, pp. 295-296) contends, in the orbit of the original Gramscian argument on hegemony by stating that 'the social field is too fragmented for one class (or, more generally, one group) to rule on its own'. It must 'widen itself ... propagating itself throughout society ... broadening its political identity' to incorporate, appropriate and subordinate a wider array of ideopolitical perspectives and interests (Purcell, 2009a). From this overall position, we interrogate which challenges, in terms of identity, direction, and position, are faced by global, network-based movements from two analytical perspectives; the internal dynamics in the formation and articulation of movements, and challenges faced by movements connected with a subordinated position within formalized spaces of governance. The first perspective is concerned with the constitution of networks of equivalence as developed by Purcell (2009a, p. 291) as an 'articulation of differentiated but equivalent popular struggles'. That is, broad coalitions of movements and groups that expose the political field as 'irreducibly plural', merging sameness and difference in terms of identity and agenda. The other main perspective concerns the limits of what has been theorized in terms of invited spaces (Gaventa, 2006) for civil society participation within intergovernmental fora.

We illustrate cardinal points through empirical reference to the case of the global network designated the People's Global Action on Migration, Development and Human Rights (here forth the $P G A) .{ }^{1}$ The PGA is a forum for a multitude of civil society activists; organizations, networks, and movements, including migrant and migrant advocacy organizations and individuals, researchers, trade unions, and faith organizations. It is mobilized as a campaign event during world governmental summits within the Global Forum on Migration and Development (GFMD), as well as periodically occurring UN summits concerned with migration and development. The PGA has sought to introduce an agenda onto the GFMD that represents the concerns of migrants, and to raise critical perspectives on human rights, labour rights, sustainable development, and the need to contest precarious livelihoods and the excessive exploitation of millions of the world's migrants.

The GFMD was initiated following the UN High Level Dialogue (UNHLD) on Migration and Development in 2006. It is the most inclusive state-led forum between governments, concerned with developing common policies for international migration. Although non-binding, and situated outside the UN system, it presents the most ambitious intergovernmental deliberations on a global governance framework on migration. Since 2007, the GFMD has figured as an arena for dialogue 
between sending, receiving, and transiting states on standards for global migration governance. Yet, the GFMD process has remained embedded in the UN framework, homecoming to regularly occurring UNHLD follow-ups, the latest of which took place in New York in 2013.

The forum is meant to be informed by the exchange of ideas with international organizations, civil society, and business. Since its inception, the so-called Civil Society Days (CSD) have been organized as a side event to the GFMD meetings. Further, since the emergence of PGA (in 2006), as a collaborative network of CSOs on the issues of migration and development, the quest for human/labour rights has become a central demand to voice within the formalized fora of the GFMD/UNHLD process. However, the PGA has come to face problems concerning deliberations within fora for global governance of migration. While the PGA has created a space for repeated appearances preceding and subsequently represented within GFMD/CSD, the movement has landed at a crossroad between representing an activist counterhegemonic movement and a position marked by a subordinated inclusion within the GFMD/UNHLD process. On this background, we reflect upon the trajectories of contestative movement activism in relation to contemporary governance.

While others have ventured in some detail into the constitution of a contestative global civil society movement for migrant rights (Piper, 2015; Rother, 2009), our purpose is to illustrate points in our theoretical discourse through commenting on impasses encountered by the PGA at crucial crossroads in the later part of its trajectory. The question we posit is whether the 'PGA' has become the insignia of a social movement in unmaking rather than in the making?

\section{Progress and prospects for the making of a 'new' global movement}

A growing body of research has called attention to the issue of the 'new' in contemporary social movements, depicting differences between what is perceived as 'old', 'new', and 'new-new' social movements. New social movement theorists (Melucci, 1989; Offe, 1985; Touraine, 1987) claim these movements differ from the 'old' - in particular from the labour movement - mainly in terms of more composite social bases (mixed) and forms of organization (localized, informal, and temporal). Feixa, Pereira, and Juris (2009) argue that globalization has resulted in 'new-new' globalized social movements (NNSM). While organized around informal networks, NNSM link locally rooted struggles to national and global events. Thus, they are 'like the neoliberal system these movements oppose', situated in a globally networked space (Feixa, Pereira, \& Juris, 2009, pp. 421-422). NNMS, they continue, 'highlight the transformations and social conflicts associated with the consolidation of informational capitalism', merging generations, genders, ethnicities, and territories, within unstable networks.

As originally imagined and devised, the highly composite global network and yearly event, the PGA, demonstrate the importance and veracity of critical interventions on issues connected with the emergence of a neoliberal migration policy regime (Schierup, Ålund, \& Likić-Brborić, 2015). The PGA was first constituted as a global civil society network event which was critically counterpoised to the UNHLD on International Migration and Development in 2006. As noted above, the UNHLD resulted in the institutionalization of the intergovernmental forum, the GFMD, as a yearly event. Since then, the PGA has recurrently taken place, parallel to, and critically counterpoising, yearly GFMD intergovernmental meetings. This began in Brussels 2007, and was followed by Manila 2008, Athens 2009, Mexico City 2010, Geneva 2011, Port Louis 2012, New York City 2013 (in conjunction with a second UNHLD), Stockholm 2014, Istanbul 2015, Dhaka 2016, and Berlin 2017. In its original form, the PGA brought together a multitude of critical networks, organizations, and movements from across six continents, while tilting towards a marked 'southern' political and 
organizational perspective. It amalgamated perspectives of 'new' diaspora movements and migrant advocacy organizations with those of a multiplicity of organizations of labour, representing 'old' as well as 'new' moral-political and organizational union orientations. The PGA as a whole appeared indeed in the stature of a 'new-new' type of global network and event. Concerning an original counterhegemonic orientation, this invites comparison with the World Social Forum on Migrations (WSFM) - founded in São Paulo as a key feature of the World Social Forum (WSF) - indicating that 'another world is possible'.

The contestative character of the PGA, as an event born out of the alter-globalization movement, was clearly expressed in its first world summits, organized as counterpoints to GFMD intergovernmental meetings, including the PGA in Mexico City, 2010. 'We are human beings with rights to mobility, freedom of speech, decent work and social protection - not a commodity', is a pledge cited from the PGA's statement targeted at the Mexican GFMD governmental forum. It echoes Polanyi's (2001 [1944]) radical critique in the Great Transformation, denouncing the unchecked commodification of labour, embodied in the migration of precarious workers from the south.

The 'International Working Group' (IWG), responsible for organizing the 2010 PGA in Mexico City, had ambitious goals in terms of building a movement that would shape a continuous policy deliberation in favour of labour, social, civic, and human rights for migrants and rebalance asymmetric power relations in the governance of migration and development in favour of 'southern' interests. The IWG included migrant umbrella federations, organizations, and networks situated in Asia, the Americas, Africa, and Europe (representing numerous community-based migrant organizations and migrant advocacy groups), as well as the Global Unions Federation (representing affiliated unions distributed over a wide array of trades) and a Mexican-based critical think tank (PGA, 2010). The Mexican PGA venue gathered more than 800 delegates from across the 6 continents, representing migrant/diaspora organizations, migrant advocacy organizations, faith-based solidarity organizations, trade unions, and academics. The venue gave witness to what Motta (2011, p. 179), in her discussion of academic versus social movement epistemology, described as 'developing utopias as part of the process of creating alternative logics of being and doing' trusting that 'movements ... can develop theoretical knowledge via a systematisation based on their political experiences'.

Regarding the importance of Mexico 2010, it should be added that the PGA obtained for the first time the opportunity to delegate representatives to CSD and a newly instituted 'Common Space' (CS) for governmental/civil society interchange, thereby acquiring a formally acknowledged place relating to the GFMD. Yet, from our participation in a range of plenums and workshops, we could also observe a range of actual or potential rifts between the motley collection of widely different networks and organizations, represented in or relating to the PGA/CSD/CS. They counted potential dissentions between labour unions and other CSOs, between different regionally situated organizations and networks, and organizations with differential positionality relating to regional, national, or local governance frameworks. This calls for an analysis of the potential challenges and pitfalls contingent on the contemporary plurality and fragmented character of social movements, and of perspectives for their formation as political subjects.

It is problematic that, as discussed by Rother (2013), there is an innate controversy between civil society actors that rely on 'outside-inside' as opposed to 'outside' strategies and tactics in relation to hegemonic discourses and institutions of governance in promoting their aims. Nevertheless, an 'outside-inside' strategy dominates the direction of the PGA. Endeavouring to promote a rights-based migration regime, it has built on global grassroots mobilization, but with the rationale of instituting a civil society agenda within major intergovernmental fora; a war of position for neoliberal times (Gramsci, 1971). A rival civil society tactic, reminiscent of a contemporary war 
of movement, has aimed to criticize and counter this dominant strategy. It puts its stakes on global alliance-making from the bottom-up, with insistent claims from the 'outside' matched by a distanced scepticism rejecting a disciplining of civil society within intergovernmental fora. ${ }^{2}$ This unsettled enigma has followed the global movement for migrant rights from its beginnings until today.

\section{Networks of equivalence - social movement as a political subject}

Departing from a Gramscian understanding of CSO and its relation to policy, Purcell (2009a) discusses the ways that fragmented struggles within global movements of the present can be brought together without ending in a uniform whole or becoming subordinated to other struggles. Like Hall (1987), he sees the work of Gramsci as the starting point to reach beyond a reductionist approach to political movements and, at the same time, still develop a collective and coordinated struggle with the potential to transform existing power relations.

With this in mind, Purcell develops the notion of 'networks of equivalence', perceived as broad coalitions that bring 'together many different struggles, movements and groups' (2009a, p. 279). In this process of coming together, there is a complex relation between sameness and difference (Purcell, 2009a, p. 279). With reference to Gramsci (1971) and Laclau and Mouffe (1985), Purcell elaborates on the notions of articulation and equivalence. This is devised to 'capture how groups join together into a counterhegemonic formation', constructing a shared common sense and a collective articulation of a new political will 'without dissolving differences into a homogenous unity' (Purcell, 2009a, p. 303), a coalitional movement amalgamating multiple subject positions.

\section{Transversal dialogues?}

This issue of a movement becoming a political subject in its own right begs for widening the space for different voices to be heard. It invites, in effect, a recapturing of a rich legacy in feminist debates.

Criticism of ethnocentricity in the mainstream feminist discourse was initiated by black feminists in the United States and Britain in the early 1980s. The essential aspects of this critique concerned the problems of either the 'invisibility' of black and ethnic women in the writings of white feminists, or their 'visibility' as victims. But, it was particularly the critique of the 'victim' perspective that opened up for new understandings of the relationship between colonial and post-colonial imaginaries, images and the struggles for the Self among oppressed peoples.

The recognition of black, ethnic, and migrant women in the texts and politics of mainstream feminism has since the 1990s been a prominent theme within international feminist studies. The perception of diversity as a threat has gradually been replaced by claims for the development of a politics of recognition for different voices in joint 'transversal' dialogues (Yuval-Davis, 1999). In order to find new modes of articulation between the universal and particular concepts such as 'differentiated universalism' (Lister, 1996) and 'transversal dialogue' (Yuval-Davis, 1999), express the need to bring forth the recognition of socio-cultural particularity into universalism, without overshadowing socially constructed inequalities appearing as divergences (Lister, 1996).

Particularly, Yuval-Davis (1999) discusses the notion of transversal dialogue within the context of 'transversal politics', aiming to bridge diversity across, for example, ethnic and political boundaries. She criticizes what she sees as an overstated confidence in universalism in discourses of feminist sisterhood, but also a limitless relativism of 'difference' caring with it cleavages and fragmentation. Yuval-Davis argues that differences, related to social, economic, and political power, should be acknowledged without replacing the notion of equality. Relating to the epistemology of stand 
point feminism, she explains the need to recognize that just one position (gender for example) is 'unfinished'. She sees, at the same time, the need for the recognition of an interconnection of other positions in terms of social, economic, political, or cultural inequality. To this end, the notion of transversal dialogue, Yuval-Davis alleges, could be important in advancing democratic deficits within contemporary social movements in order to avoid either 'over universalism' or 'over relativism'. Thus conceived, 'transversal politics' stands out as an alternative to an assimilationist, ostensibly 'universalistic' politics on the traditional left, but at the same time also to a fragmenting identity politics obsessed with 'difference'.

Let us now relate transversal dialogues to the issue of the global movement for migrant rights. In this connection, there is a diacritical watershed between labour unions, on the one side, and other organizations and movements of civil society such as migrant organizations and an array of NGOs, on the other. They have different management styles and approaches to tackling inequality. While the latter tend to congregate around demands propagating 'human rights', often packed in a moralistic discourse, the legitimacy and mandate of the former do not depend on a human rights discourse. Rather, trade unions obtain their organizing mandate from workers who need collective representation to face employers and the state (Schierup, Munck, Likic-Brboric, \& Neergaard, 2015, p. 12). They are often very formal organizations, which tend not to engage with the informal economy or people whose livelihoods are most precarious. NGO programmes, on their part, are often 'concerned with manifestations of extreme poverty and are accustomed to working in the informal sector but they have little sense of the significance of labour rights as such' (Piper \& Grugel, 2015). While trade unions may be slow to act, although have long term and overtly political horizons, NGOs are often project-based, dependent on a constant struggle for government or corporate funding, and tend towards settling with a 'watchdog role'.

On this background, a dialogue traversing differences and potential controversies is necessary (Piper \& Grugel, 2015) in order to accomplish a counterhegemonic formation capable of sustaining demands for a restructured global governance of migration. Such a dialogue indeed was vivid on the occasion of the 2010 PGA and that year's CS days in the GFMD. But, later events would demonstrate that a window of opportunity limited to vague promises of 'respect for human rights' does not provide an adequate discursive and institutional space for productive transversal dialogue and powerful and sustainable alliances traversing these divides within a wider civil society.

\section{The limits of invited spaces}

Any movement of civil society, operating within the framework of dominant institutions - be they local, national, or transnational - face risks connected with co-optation. It has indeed been inferred that the current public attention paid to civil society and new social movements are related to the preceding decades' neoliberal reorientation - a process in which CSOs have become key players involved with the expansion of market principles. Kaldor (2003), for one, discussing the dilemmas of global civil society in the context of wars and complex emergencies, links imaginaries and agency of contemporary social movements to the transformation of civil society from an 'activist' into a neoliberal model. Here, civil society functions as a substitute for the state, which has pulled back from public service delivery, with the consequence of social movements turning into a market of NGOs/ INGOs. Becoming institutionalized, they service functions of a retiring state, including human rights consultation, combating poverty, conflict resolution, education, and training in democracy and citizenship. In contemporary development studies, CSO/ICSOs have increasingly been seen and engaged as central agents for the promotion of democracy in the governance of developmental 
processes. But, as contended by Veltmeyer (2009, p. 90), in the course of their engagement in 'participatory development', they have been induced to adopt tactics of subtle deliberation rather than 'confrontationalist politics of direct action'. In this process, they have often become transformed from contentious movements into institutionalized and pragmatically orientated NGOs. It is a development which is inherently connected with the dynamics and limitations of invited spaces for civil society participation in contemporary forms of governance.

The concept of 'invited spaces' originates from the work of Brock, Gaventa, and Cornwall (2001). It was further developed in different contexts by, for example, Cornwall (2002), Gaventa (2006), and Miraftab (2004, 2009). Invited spaces are, as argued by Gaventa (2006, pp. 26-27), related to participatory governance, formalized at different levels from local government, to national policy and even in global policy forums. Aiming at the creation of more open arenas for citizen participation, citizens 'are invited to participate by various kinds of authorities and organisations, be they government, supranational agencies or non-governmental organisations'. These spaces are 'either institutionalised ongoing, or more transient, through one-off forms of consultation' (Gaventa, 2006, pp. 26-27).

Referring to Cornwall (2002), Miraftab (2004) applies the notion of invited spaces in her analyses of local governance in Cape Town, South Africa. She defines invited spaces 'as the ones occupied by those grassroots and their allied non-governmental organizations that are legitimized by donors and government interventions' (Miraftab, 2004, p. 1). She furthers that 'invented' spaces are in contrast those also occupied by the grassroots and claimed by their collective action, but directly confronting the authorities and the status quo. Either through inventing new spaces, re-appropriating old ones or by moving between these spaces, grassroots movements employ counterhegemonic practices in order to 'expose and upset the normalized relations of dominance' (Miraftab, 2004). Or spoken through a Gramscian terminology, they launch a war of position (Miraftab, 2009, p. 34).

Counterhegemonic movements can be strengthened in the processes of state decentralization and the related emergence of new forms of local governance. This global trend, on one side, can provide openings for grassroots movements and other forms of social justice struggles to be recognized through local formal channels for citizen participation and claims within formalized spaces of invited dialogues. Thus, Miraftab (2009, p. 34) maintains that '[t]hrough persistent counter-hegemonic practices, these movements expose and upset the normalized relations of dominance'. But, a hegemonic move from above that institutionalizes participatory development and supports partnerships between states and NGOs can also result in the institutionalization and de-politization of grassroots movements.

\section{Pacification through appropriation?}

Pacification through appropriation appears indeed to be relevant for the development of the PGA. It resounds in comments from William Gois - the leader of Migrant Forum in Asia and an important organizer of PGA events during years - related to the PGA's position and impact, expressing worries relating to an eventual appropriation of PGA language officially for governments and multilateral organizations. Might it mean recognition or pacification, he pondered in his concluding statement at the seventh global summit of the PGA, organised in New York, October 2013, as a parallel civil society event to the UNHLD on Migration and Development, realized through commitment by local CSOs.

The New York HLD (NY HLD) had been preceded by the formation of the Global Coalition of Migration $(\mathrm{GCM})^{3}$ as a standing representative body of regional and international networks of 
migrant associations, migrant rights organizations and advocates, trade unions, faith groups and academia, covering most major regions of the globe. It was constituted on the basis of the mobilization that had taken place since 2006 within fora such as the WSFM and the PGA. It had coordinated one year's scrupulous work laid down in elaborating a five-year action plan to be presented to the governments and international organizations on the occasion of the HLD. Yet, the actual results of the HLD were less than pleasing for many.

While Gois' statement at the New York PGA reflected ambiguity, an open letter to the UN Secretary, Ban Kimoon, by the powerful Global Unions (member of the GCM) expressed, in a highly critical idiom, a frustration with the GFMD process in general, and the HLD in particular. Here, the governments and the UN's 'invited space' for deliberations with civil society stands out as at best symbolic, but in reality is monitored and disciplined by a screening process through which:

[a]t every juncture in the process, civil society members have faced significant roadblocks. For over a year, hundreds of representatives from national, regional and international organisations met in over 20 preparatory events around the world and in a UN civil society hearing to develop our inputs to the HLD. Despite this great effort to achieve shared analyses, it appears those views will be ignored. (Global Unions, 2013)

The 2013 HLD expressed a modus operandi of hegemonic governance. The letter brings this out further, through which the organizations that represent workers were effectively excluded from having any voice in the scant civil society hearings that actually took place. 'A major labour recruiter granted an award by the World Economic Forum for operating an "ethical labour supply company" was given an opportunity to address member states, as was a for-profit development firm', argues Flecker (2014) in a similar critique of the 2013 HLD, 'but not the civil society rapporteur who had been pre-selected earlier in the year, nor representatives from any organizations that represent workers'.

It was conceivably, by inference, a way of marginalizing the labour unions in their capacity of the most critical, politicized, and potentially powerful partner in the global movement for migrant rights, which had for years been developing within fora like the WSFM and the PGA, while, at the same time extending the space for more complacent and readily co-opted actors. The consequences have been dismal in sapping the engagement of international unions in the GFMD process, as well as in amputating a necessary and productive transversal dialogue between organized labour and other civil society solidarity organizations. It appeared to harbinger the beginning of the end of the PGA as a viable 'invented space' running in tandem with its co-optation and neutralization as a dynamic politicized forum.

In particular, the GFMD and UN's systems increased gravitation towards the propagation of policies mainstreaming temporary and circular migration as universal win-win-win formula (for emigration countries, receiving countries, and migrants themselves) ${ }^{4}$ has become a stumbling block for trade union engagement. In conjunction with an apparent incapability of an organized civil society to place radical alternatives onto the agenda, this has continued to estrange a variety of trade union activists, envisaging damaging effects of temporary schemes for labour and to social cohesion. Former PGA activist, Flecker (2011, p. 53), for one, concludes the following in an analysis (on behalf of the Canadian Labour congress) of Canada's temporary worker schemes, commonly held out in intergovernmental meetings as an ideal model to follow by others:

Canada's Temporary Foreign Worker Program is far from being a model initiative. Given the experiences of the Canadian labour movement, it is abundantly clear that the program's design permits the 
exploitation of migrant workers. It operates to serve employers' interests with little meaningful regard for compliance, monitoring, or enforcement of national or subnational labour standards.

\section{Screening, embedding and NGOizing civil society}

While Mexico 2010 could be seen as a high-point concerning the potentiality of the PGA as an outside-inside civil society player related to the global governance of migration, the occasion of the UNHLD can be seen as a critical marker of its decline. This concerns both its potential as a node for transversal dialogue within a variegated civil society, and its impact within the 'invited space' of the GFMD.

After the NY HLD, a further confirmation of an uncritical win-win-win formula of temporary migration as the standard baseline for deliberation, could be observed in subsequent GFMDs in Stockholm 2014 and Istanbul 2015, with Sweden and Turkey as respective host countries. It stood forth as a settled preference, which did not help to further promote the engagement of trade unions in a transversal dialogue within civil society, nor, through inference, to strengthen the clout of the PGA's 'outside-inside' strategy vis-à-vis the GFMD. The marginalization of trade union perspectives in the forum was, at the same time, exacerbated through a changing balance of power and influence between the International Labour Organization (ILO) and the International Organization for Migration in favour of the latter. It has implied a predilection towards a neoliberal perspective on the management of migration in general (Flecker, 2014; Likic-Brboric \& Schierup, 2015).

In tandem with the increasing fading out of the PGA's outside-inside strategy, post-NY HLD, the International Catholic Migration Commission (ICMC) - a since long established humanitarian INGO within the field of migration - came to undertake the task of embedding and NGOizing global civil society agency within the GFMD process. It was a mission instrumentalized on the occasion of the Stockholm CSD/GFMD through founding the Migration and Development Civil Society Network (MADE), predominantly funded by European governments and largely loyal to preferences inscribed in the mainstream EU migration governance framework. The ICMC was also accorded a gate-keeping role in channelling GFMD-related funding earmarked for financing participation of civil society delegates in the CSD and thereby, indirectly, also in the PGA summits adjacent to the GFMD/CSD.

In the case of the Stockholm GFMD, 2014, the type of screening process criticized by the Global Unions in New York could be observed in action on the (Swedish) national level. Here, the ICMC's local Swedish sister organization, Caritas Sweden, was, on behalf of the ICMC and in close collaboration with the Swedish government, put in charge of the preparatory selection of delegates for the CSD and CS of that year's GFMD. From our discussions with the migration policy responsible in the Swedish Trade Union Confederation (LO) during the Spring of 2014, we could record frustration and anger, similar to what was expressed in the Global Unions' letter to the UN General Secretary in 2013. It was provoked by feelings of belittlement, without the space for expressing views, which diverged from those of the Swedish government and the dominant GFMD line. It appeared decisive for a remarkable absence of interest, from the unions, in the CSD and in a PGA, which had - void of independent funding sources - at this stage, become highly dependent on the ICMC which was now in command of screening and financing civil society delegates to the GFMD. Through this, the ICMC was also indirectly responsible for the participation of the very same individuals in the PGA, in advance of the GFMD. A similar critique from the unions, as in New York, 2013, and Stockholm 2014, was made in a briefing paper by Global Unions (2015) on the GFMD process in Istanbul 2015. The paper expressed concerns about the slow progress made by the GFMD in terms of 
accountability, transparency, and inclusivity, and about a growing impact of the business community in migration policy, with unions and civil society in general relegated to a peripheral space. It opted for an ILO-led tripartite model of consultations in partnership with migrant workers' associations.

On the background of a frail impetus and a flagging coherence of civil society, in particular concerning the partnership between unions and other civil society actors, the PGA meeting in Istanbul was to become a turning point, marked by self-critical reflection. At this meeting, preceding the Istanbul GFMD, the aforementioned William Gois expressed clearly what it meant in terms of nostalgia 'for the spirit that once existed' in pondering: ${ }^{5}$ 'We thought that we have a synchronised focus on Human Rights. We started losing that spirit and have to go back to the roots ... we have to find it again'. Comments from the floor further clarified what is at stake with the PGA: 'It is being institutionalised ... Rather than to speak about what is the real agenda we are spending too much time on who is chairing discussions in the CSD/CS ... While becoming a chair you cannot criticise'.

\section{Enigmas of civic activism: straddling policy, political, and democratic spaces}

This 'losing of the spirit' and becoming institutionalized within invited spaces related to neoliberal governance is, evidently not particular for the PGA, but generally problematic, widely discussed among civil society activists as well as in the social sciences.

Gaventa (2006, p. 23), for one, argues in discussing new spaces emerging around the world and aiming to promote opportunities for citizen engagement in policy processes, that creating new institutional arrangements will not lead to profound policy change. Rather he claims, this will depend on the nature of the power relations, in which new, potentially more democratic, spaces are embedded. He raises a number of critical questions related to issues of the democratic within invited spaces:

Does this new terrain represent a real shift in power? Does it really open up spaces where participation and citizen voice can have an influence? Will increased engagement within them risk simply re-legitimating the status quo, or will it contribute to transforming patterns of exclusion and social injustice and to challenging power relationships? (Gaventa, 2006, p. 23)

This kind of understanding can be applied to the position of the PGA and the CSD/CS within spaces for invited deliberation (the UN, GFMD, etc.). The rhetoric of participation and the use of the same language on human rights (within the PGA, the UN, and the GFMD), as William Gois referred to in the PGA meeting in New York (parallel to the UNHLD) 2013, corresponds to Gaventa's (2006, p. 23) reflections on the limits of new arrangements, which call for 'co-governance' and 'participatory governance'. Can they actually, he asks, 'challenge our traditional categories of the rulers and the ruled, the policymakers and the public'?

What is at stake could be captured by what Miraftab $(2004,2009)$ discusses in terms of 'symbolic inclusion'. It relates to multifaceted forms of power and dominance within a rhetoric of so-called partnership and shared ownership. As Gaventa explains, when used by large, powerful actors such as the World Bank and the International Monetary Fund to 'invite engagement on a "level playing field" [this] obscures inequalities of resources and power', it blurs 'traditional "us" and "them" distinctions between economic power holders and those who might negatively be affected by their corporate practices' (Gaventa, 2006, p. 23). The argument points at the distinction between power with (cooperation, collective action, alliance-building) and power over (domination), which neutralizes power to act, that is activism. But power with - that is building 'links between situated knowledge and mobilisation and broader international advocacy work' is essential for the making of a political 
space - a point of departure for collective action, 'in order to challenge global economic power' (Gaventa, 2006, pp. 25-26).

But, what is then political space? The political can start with being situated within new terrains of invited space for citizens' dialogues that correspond to the meaning of space as a dynamic social field of struggles; 'a social product', humanly constructed and including control, domination and power relations (Gaventa, 2006, p. 26). ${ }^{6}$ If we apply this perspective to the PGA as a global migrant network, it is important to emphasize the distinction between policy space and political space. While the former refers to meeting places for deliberation between citizens and policymakers (such as the GFMD's 'CS'), the latter relates to institutional channels, political discourses and practices through which precarious people and contending organizations working with them can pursue social justice, human rights and poverty reduction (cf. Gaventa, 2006, p. 26). Although these questions are inherent within regular documents formulated at PGA meetings, which address the UN and the GFMD, the primary expectations of PGA members are focused on realizing genuine democratic dialogue and influencing the global governance regime politically. It implicates, in consequence, what Gaventa refers to as democratic space; a space 'in which citizens can engage to claim citizenship and affect governance processes' (Gaventa, 2006, p. 26, with reference to Cornwall \& Coehlo, 2006). It would lend substance to the idea of 'invited dialogue' within, for example, the CS as a meeting place for deliberation between civil society, states, and international organizations within the GFMD framework. Such an 'invited space' ought, with reference to the expectations of PGA delegates, to be 'democratic spaces' related to, as formulated in general terms by Gaventa (2006, p. 26), 'opportunities, moments and channels where citizens can act to potentially affect policies, discourses, decisions and relationships that affect their lives and interests'.

However, as evident from deliberations at the PGA meeting in Istanbul 2015, the actually existing policy space in the GFMD process hardly functions as a democratic space from the perspective of civil society. The institutionalization of civil society is not necessarily counterproductive in itself, but can bring with it a tamed and de-politicized NGOization if controlled by the self-same dominant political and economic interests; the politics and policies, which have originally been the object of contestation. It is an enigma observed, in the global north as well as the south, as imminent in the staging of invited spaces. ${ }^{7}$ This, in turn, implicates the necessity of a continuous revival and renewal of civil society alliances in order to develop a counterhegemonic network of equivalence that amalgamates multiple subject positions within a powerful coalitional movement: that is, to constantly strengthen a composite movement from within. This is a still unsettled issue. It has been the object of critical/selfcritical debate in Istanbul 2015, and has continued in PGA venues in both Dhaka 2016 and in Berlin 2017, with a conceivably more potent and less disciplinary financial/organizational backing that those in for example Stockholm and Istanbul.

The discussions at the Berlin PGA meeting in 2017 contended that the PGA, and the wider institutionalized and permanent civil society fora which have originally emanated from it (e.g. GCM and MADE), need to reconnect to activist, radical and fundamental beliefs, and responsibilities (PGA, Panel 3 on 'Institutional Obstacles'). Envisaging its upcoming venue in Morocco in 2018, the PGA's still essential mission was stressed, regionally as well a globally. The need for a critical perspective on civil society actors captured by government interests was emphasized, as well as the need for strengthening autonomy through the revitalization of regional and global alliances. In this perspective, participants pointed to the importance of strengthening partnerships with labour unions. Others emphasized the strengthening of bonds with fora outside the narrow purview of the GFMD, such as the WSFM; an invented space, which sprung from the WSF, with similar visions 
as those originally grounding the PGA, but wider autonomy. After all, in spite of a discouraging experience, at times, for many activists, the original radically critical values and positions of the PGA as an invented space remain a fundamental platform.

\section{Contestation or appropriation? Vagaries of an inside-outside strategy}

As we have laid out in the preceding discussion, there are obvious problems connected with contemporary movement strategies bound into an ambiguous position as both participating in 'dialogue' within 'invited spaces' and with counterhegemonic ambitions to transform existing power relations. We have illustrated this with the case of the PGA as a global movement in the making, positioning itself as counterpoised to the intergovernmental forum of the GFMD. Recording self-reflections of movement activists in the PGA in the course of the 2013 UNHLD, and later in Stockholm 2014, Istanbul 2015, and Berlin 2017, we have depicted this mission as connected to risks of a depoliticizing co-optation. Without subscribing outright to the idea of a universal 'stage model' (Coy \& Hedeen, 2007 [2005]), we do see, in conclusion, co-optation as a complex amalgamating process, beyond single acts or particular events, as expressed on different levels and as potentially incremental, typically proceeding through consecutive and tendentially cumulative steps.

The start of the PGA as nodal point for a contending movement was, seen in this perspective, marked by the inception of a collective global engagement. It was focused on what had been identified as a widely shared issue of dispossession and social justice with activists representing the global south at the forefront. It was premised on the identification of a multitude of civil society actors with joint demands for change to be advanced through an 'inside-outside' contestative strategy, sustained by a globally extended 'network of equivalence'. It called, from the perspective of migrant organizations and migrant advocacy NGOs/INGO's, for the rapport with powerful, but every so often ambivalent, allies among global unions. This was based on struggles over the precarity of contemporary labour relations; nationally, regionally, and globally. We have illustrated vagaries connected with managing this puzzle through the course of events at the UNHLD in New York 2013. Therefore, we could witness, on site, an already ambivalent positionality of the labour unions, becoming exacerbated by their progressive marginalization in the context of a covert process of inclusionary, but selective and subordinating, hegemony management by governments, business interests, powerful international organizations, and the chosen gate-keeping humanitarian INGOs.

A powerful marker of co-optation was, at this stage, the parallel, almost universal appropriation by governments of the discourse of 'human rights', hitherto flown as the frontal parole of civil society; yet henceforth (as captured by disorientated self-reflection of movements activists) as a floating, and tendentially 'empty', non-obliging signifier. In essence, a moral 'last utopia' (Moyn, 2010) in the age of neoliberal globalization where the twentieth century's totalizing ideopolitical conceptions of 'social justice' have been declared dead by default. Yet, as contended by Moyn (2010, p. 227), if human rights shall relate to 'core values that demand protection they cannot be all things to all people ... the last utopia cannot be a moral one'. A moral discourse of 'human rights', but without a distinct prominence of labour rights and labour protection, and social rights in general, is of limited interest to trade unions in particular. The Stockholm GFMD was marked by a further step towards co-optation of civil society via a transition from the appropriation of movement language to a condition of in-depth 'institutional appropriation' (Coy \& Hedeen, 2007 [2005]). It was a process also signified by the tendential assimilation of movement leaders and movement programmes, bound up through financial control by a powerful humanitarian INGO as the gatekeeper (the ICMC). We have, in tandem with a global policy shift, depicted this process of increasingly deep-seated appropriation 
of a movement in the making - thereby tendentially 'unmaking it' - as intertwined with a process of consensual hegemony making. It is, more specifically, spun around an appropriative and dispossessing so-called win-win-win formula of 'managed migration', prioritizing the local and global interests of employers and migrant receiving countries.

Let us, in this vein, conclude by quoting Brubaker's ${ }^{8}$ comment that 'in relationships marked by power imbalances, cooperation and co-optation are nearly indistinguishable'. The implications appear clear, and the concept of 'space' is of discriminating importance. While the PGA and similar civic networks and movements of civil society are struggling to gain influence within formal 'invited spaces', they need to continuously critically recreate and consolidate their own 'invented spaces', in order to be able to develop a sustainable capacity as counterhegemonic political subjects. This implicates, among others, as addressed by movement activists in Berlin, a revived process of transversal dialogue bringing the unions solidly back into a strengthened, more autonomous and sustainable 'network of equivalence'.

\section{Notes}

1. Information on the history and politics of the PGA is available at, among others: http:// peoplesglobalaction.org/about/history/.

2. Represented by, e.g. the International Assembly of Migrants and Refugees (Rother, 2013).

3. Founded in connection with the PGA meeting connected with the GFMD in Geneva, 2011.

4. See Triandafyllidou (2013) and Fudge and Strauss (2013) for critical analyses of schemes of circular and temporary migration (2013).

5. Referring, in particular, to the PGA summit in Manila, 2008.

6. Referring to Lefebvre (1991) and Cornwall (2002).

7. For example, Wikström and Lundström (2002), Kaldor (2003), Veltmeyer (2009), Neocosmos (2011), Léon-Rosales and Ålund (2017).

8. Brubaker (2003), quoted in Coy and Hedeen (2007 [2005]).

\section{Disclosure statement}

No potential conflict of interest was reported by the authors.

\section{Funding}

This article is a contribution to the Swedish Research Links project, 'Migration and development. What space for civil society in global governance? (MIGLINK)', with financial support through the Swedish Research Council [grant number 348-2013-6682]. 


\section{References}

Ålund, A., Schierup, C.-U., \& Neergaard, A. (2017). Reimagineering the nation. Essays on twenty first century Sweden. Frankfurt am Main: Peter Lang.

Brock, K., Gaventa, J., \& Cornwall, A. (2001). Power, knowledge and political spaces in the framing of poverty policy. Brighton: IDS.

Brown, W. (2005). Edgework: Critical essays on knowledge and politics. Princeton, NJ: Princeton University Press.

Brubaker, D. (2003, April 3-7). Personal comments during discussion at 'Restorative Justice and Conflict Transformation: Friends or Foes' presentation by Michelle Armster and Lorraine Stutzman-Amstutz at NCPCR-PeaceWeb Conference, April 6, 2003, Atlanta, Georgia.

Cornwall, A. (2002). Locating citizen participation. IDS Bulletin, 33(2), 49-58.

Cornwall, A., \& Coehlo, V. (Ed.). (2006). Spaces for change? The politics of citizen participation in new democratic arenas. London: Zed Books.

Cox, R. W. (1983). Gramsci, hegemony, and international relations: An essay in method. Millennium: Journal of International Studies, 12(1), 162-175.

Coy, P. G., \& Hedeen, T. (2007 [2005]). A stage model of social movement cooptation: Community mediation in the United States. Retrieved from https://eds-a-ebscohost-com.e.bibl.liu.se/eds/detail/detail?vid=2\&sid= 259e066a-bcdd-49a5-9712-be8bdde4819f@sessionmgr4006\&bdata=JnNpdGU9ZWRzLWxpdmUmc2Nvc GU9c210ZQ==\#AN=17567536\&db=edb

Deak, A. (2005). The condition of hegemony and the possibility of resistance. Undercurrent, 2(3), 46-56.

Feixa, C., Pereira, I., \& Juris, J. (2009). Global citizenship and the 'new, new' social movements. Iberian connections. Young, 17(4), 421-442.

Flecker, K. (2011). Model program - or mistake? Canada's temporary foreign worker program (TFWP). Toronto: Canadian Labour Congress.

Flecker, K. (2014). Not wanted on the voyage. Migrant workers' needs and rights continue to be ignored. The Monitor. Retrieved from https://www.policyalternatives.ca/publications/monitor/not-wanted-voyage

Fudge, J., \& Strauss, K. (Eds.) (2013). Temporary work, agencies, and unfree labor. Insecurity in the new world of work. New York, NY: Routledge.

Funke, P. N. (2014). Building rhizomatic social movements? Movement-building relays during the current epoch of contention. Studies in Social Justice, 8(1), 27-44.

Gaventa, J. (2006). Finding the spaces for change: A power analysis. IDS Bulletin, 37(6), 23-33.

Gill, S. (2003). Power and resistance in the new world order. London: Palgrave.

Global Unions. (2013). Open letter to United Nations Secretary General Ban Ki-moon concerning trade union and civil society inclusion at the High-level Dialogue on Migration and Development New York, October 34, 2013. Public Services International. Retrieved from http://world-psi.org/en/support-our-action-sign-letter

Global Unions. (2015). Global unions briefing paper: 2015 Global Forum on Migration and Development. Brussels: Author.

Gramsci, A. (1971). Selections from the prison notebooks of Antonio Gramsci. (H. Quinton \& G. N. Smith, Eds.), New York, NY: International.

Hall, S. (1987, June). Gramsci and us. Marxism Today, pp. 16-21.

Kaldor, M. (2003). Global civil society. An answer to War. Cambridge: Polity Press.

Laclau, E., \& Mouffe, C. (1985). Hegemony and socialist strategy. London: Verso.

Lefebvre, H. (1991). The production of space. London: Verso.

Léon-Rosales, R., \& Ålund, A. (2017). Renaissance from the margins - Urban youth activism in Sweden”. In A. Ålund, C.-U. Schierup, \& A. Neergaard (Eds.), Reimaginiering the nation. Essays on Swedish society (pp. 351-374). Frankfurt am Main: Peter Lang.

Likic-Brboric, B., Schierup, C.-U. (2015). Labour rights as human rights? Trajectories in the global governance of migration. In C.-U. Schierup (Ed.), Migration, precarity and global governance (pp. 223-244). Challenges for labour. Oxford: Oxford University Press.

Lister, R. (1996, July 16-18). Citizenship: Towards a feminist synthesis. The Conference: Women and Citizenship, University of Greenwich, London.

Melucci, A. (1989). Nomads of the present social movements and individual needs in contemporary society. Philadelphia, PA: Temple University Press. 
Miraftab, F. (2004). Invited and invented spaces of participation: Neoliberal citizenship and feminists' expanded notion of politics. Wagadu, 1(Spring 2004), 1-7.

Miraftab, F. (2009). Insurgent planning: Situating radical planning in the global south. Planning Theory, 32(8), $32-50$.

Motta, S. C. (2011). Notes towards prefigurative epistemologies. In S. C. Motta, \& A. G. Nilsen (Eds.), Social movements in the global south. Dispossession, development and resistence (pp. 178-199). Houndmills: Palgrave Macmillan.

Moyn, S. (2010). The last utopia: Human rights in history. London: Belknap.

Neocosmos, M. (2011). Transition, human rights and violence: Rethinking a liberal political relationship in the African neo-colony. Interface: A Journal for and About Social Movements, 3(2), 359-399.

Offe, C. (1985). New social movements: Challenging the boundaries of institutional politics. Social Research, 52 (4), 817-868.

People's Global Action. (2010). 2010 Peoples Global Action on migration development. MFA, Migrant Forum in Asia. Retrieved from http://mfasia.org/2010-peoples-global-action-on-migration-development/

Piper, N. (2015). Democratising migration from the bottom up: The rise of the global migrant rights movement. Globalizations, 12(5), 788-802.

Piper, N., Grugel, J. (2015). Global migration governance, social movements and the difficulties of promoting migrant rights. In C.-U. Schierup (Ed.), Migration, precarity and global governance. Challenges for labour (preliminary title) (pp. 261-279). Oxford: Oxford University Press.

Polanyi, K. (2001 [1944]). The great transformation: The political and economic origins of our time. Boston, MA: Beacon Press.

Purcell, M. (2009a). Hegemony and difference in political movements: Articulating networks of equivalence. New Political Science, 31(3), 291-317.

Purcell, M. (2009b). Resisting neoliberalization: Communicative planning or counter-hegemonic movements? Planning Theory, 8(2), 140-165.

Rother, S. (2009). 'Inside-Outside' or 'outsiders by choice'? Civil society strategies towards the 2nd Global Forum on Migration and Development (GFMD) in Manila. Asien, 111(April), 95-107.

Rother, S. (2013). A tale of two tactics: Civil society and competing visions of global migration governance from below. In M. Geiger \& A. Pécoud (Eds.), Disciplining the transnational mobility of people (pp. 41-62). Houndmills: Macmillan.

Schierup, C.-U., Ålund, A., \& Likić-Brborić, B. (2015). Migration, precarization and the democratic deficit in global governance. International Migration, 53(3), 50-63.

Schierup, C.-U., Munck, R., Likic-Brboric, B., Neergaard, A. (2015). Introduction: Migration, precarity and global governance: Challenges and opportunities for labour. In C.-U. Schierup (Ed.), Migration, precarity and global governance. Challenges and opportunities for labour (pp. 1-24). Oxford: Oxford University Press.

Touraine, A. (1987). Social movements: Participation and protest. Scandinavian Political Studies, 10(3), 207-222.

Triandafyllidou, A. (Ed.). (2013). Circular migration between Europe and its neighbourhood. Choice or necessity? Oxford: Oxford University Press.

Veltmeyer, H. (2009). Democratic governance and participatory development: The role of development NGOs. The Whitehead Journal of Diplomacy and International Relations, 6(Summer/Fall), 89-109.

Walton, J., \& Udayagiri, M. (2003). Global transformation and local counter movements: The prospects for democracy under neoliberalism. International Journal of Comparative Sociology, 44, 309-343.

Wikström, F., \& Lundström, T. (2002). Den ideella sektorn: Organisationerna i det civila samhället. Stockholm: Sober Förlag/European Civil Society Press.

Yuval-Davis, N. (1999). What is 'transversal politics'. Soundings, 12, 94-98. 


\title{
The problem of representation: civil society organizations from Turkey in the GFMD process
}

\author{
Cavidan Soykan and Nazlı Şenses (1)
}

\begin{abstract}
This paper focuses on the global governance of migration and the problem of migrant representation and migration-related problems within its framework. It concerns an analysis of the participation of civil society organizations (CSOs) in the summit of Global Forum on Migration and Development (GFMD) which took place in Istanbul in 2015. The authors analyse the Turkish chair's presentation of migration-related problems and how this relates to the representation of migrants in Turkey by Turkish CSOs. Thus, the 2015 GFMD in Turkey is utilized as a case to reflect upon problems of representation. Furthermore, its democratizing potential as an informal, multi-sited framework for deliberations on new global migration governance avenues is recognized. Based on the participant observation, the authors maintain a critical stance concerning the inherent problems of the GFMD framework as a space for representing civil society in general and migrants and their organizations in particular.
\end{abstract}

\section{Introduction}

Known as a migrant sending country for years, Turkey opted to host the eighth Global Forum on Migration and Development (GFMD) in 2015 in Istanbul. This was at a time when Turkey had become recognized as the most important refugee receiving country in the world by the Office of the United Nations High Commissioner for Refugees (UNHCR, 2015a). In July of 2015, just a couple of months before the Istanbul GFMD, Turkey was host to nearly two million Syrians, and Turkey's non-Syrian caseload hit a new record of 350,000 applications the same year (UNHCR, 2015b). However, Turkey does not grant refugee status to non-European asylum applicants and is one of the four countries that applies a geographical limitation for the implementation of the 1951 Convention Relating to the Status of Refugees (1951 Refugee Convention). While the non-European applicants receive conditional refugee status until resettlement in another country via the UNHCR, Syrians are granted temporary protection.

Turkey's GFMD role coincided with a historic transition in the country's migration management policy. Its first ever asylum law, the Law on Foreigners and International Protection, was adopted by the parliament in 2013 in line with Turkey's European Union (EU) candidacy process. Ever since Turkey became party to the 1951 Refugee Convention, a civil institution instead of the police has been set to manage migration and migrants' rights. However, the new law combined refugee protection with a discourse of criminalization and control according to EU interests. In practice, the new 
migration and asylum law was adopted to reorganize the field governing migration at the national level. However, the new law did not cover mass displacement situations. Keeping Syrian refugees out of this legal framework, therefore, allowed the government to follow its own policy regarding the situation in Syria (Atac et al., 2017, pp. 12-13). With the highly acknowledged, but currently halted, open door policy towards Syrians, Turkey has suddenly appeared as an important figure in the arena of global migration governance.

Global migration governance is a complex, multilevel framework. It involves formal and informal institutions, as well as state and non-state actors, working on global migration management at different levels such as bilateral, regional, interregional, and transnational (Betts, 2011; Piper, 2015; Piper \& Rother, 2014). Despite its transboundary character, international migration has not been part of a formal regime under the United Nations (UN) mandate (Betts, 2011). There is no UN migration organization in the sense that the UNHCR works for refugees. Although an International Organization for Migration (IOM) exists in the area, it did not have a mandate defined by the international community (Betts, 2011, p. 7).

Starting from the 1990s, a growing number of international organizations have become involved in migration management with different roles. New ad hoc initiatives, i.e. the GFMD, have also emerged outside the formal UN system without normative authority. The most central characteristic of these initiatives is the inclusiveness of different actors such as international non-governmental organizations, the private sector and migration experts. According to Betts (2011, p. 2), in the absence of a top-down multilateral framework, these types of ad hoc, multi-level migration governance forms enable states to selectively decide on different issues to address, in different informal settings and with different partner states. Betts optimistically claims that alongside multilateral agreements, we can hence talk of an emergence of what might be called 'facilitative multilateralism'. This does not aim at forming formal multilateral collaboration but allows states to engage in discussion and information-sharing as the means to develop bilateral cooperation. He further argues that because the GFMD does not aim at producing formal interstate agreements, but rather facilitates dialogue between states and civil society, it can be conceived as a type of 'facilitative multilateralism' (Betts, 2011, pp. 12-13). While Betts finds this fragmented structure is functional, it should be noted that power relations play an important role in knowledge production and policymaking at the global level. As Geiger and Pécoud (2010, pp. 9-10) underline, policy discourse shapes the construction of reality and the perception of the 'problems' addressed by governments. The global policy discourse may not only create 'problems' to be discussed at these types of forums, but also eliminates the others that clash with the political interests of states (Geiger and Pécoud, 2010).

This paper questions the argument of facilitative multilateralism by focusing on the Civil Society Days (CSDs) of the GFMD. To achieve this, we utilize the 2015 GFMD in Turkey as a case study. By collecting empirical evidence both from a GFMD-related research project, MIGLINK, ${ }^{1}$ and our participation in the 2015 GFMD as civil society delegates, this paper seeks to assess whether or not civil society organizations (CSOs) can create their own space and push for their own counter-discursive arguments within this multi-level framework. Particularly, we argue that in order to define the GFMD framework as a type of facilitative multilateralism, there should first be the representation of migrants and their claims for rights. This is mainly because civil society, i.e. pro-migrant CSOs, activists and movements, claim to represent a rights-based perspective in global migration governance. We propose that there needs to be recognition by civil society of the actual migrant conditions in receiving societies that could identify migration-related problems. Our theoretical analysis is partly inspired from the study of Grillo (1985) which puts forward a critical discussion on the 'representation of problems' and the 'problem of representation' in the politics of migration. We also 
focus on civil society activism literature with regard to space and power relations. As Ålund and Schierup (2018) also discuss, the work on the 'invented' and 'invited' spaces (Gaventa, 2006; Miraftab, 2004) provides a solid theoretical basis to evaluate the quality of representation within the GFMD/CSDs and/or has democratizing potential within global migration governance. In other words, we scrutinize if the GFMD 'space' was able to incorporate the migrants' voice into the multilevel framework of global governance. At this point, it is important to note that our empiri$\mathrm{cal}$ analysis, and hence the scope of this paper, is limited to the GFMD in Turkey. Thus, our findings may not be generalized but still carry some theoretical implications for evaluating the process of the GFMD as well as the potential of the current global governance framework in meeting the democratic deficit.

The next section describes the basic logistics and main processes of the GFMD framework with a specific focus on the CSDs. Thereafter, we develop a theoretical framework that helps us examine the relationship between the representation of migrants and the democratizing potential of the GFMD and CSDs. In the empirical analysis, we first look at how Turkey, as the biggest refugee-hosting country in the world, defined and presented the migration-related problems for the Forum. It is important to note that how Turkey put forward the key issues related to international migration for the GFMD 2015 agenda is itself a political choice. Within this politically constructed discourse, civil society members aim to articulate an alternative vision based on human and labour rights (Piper \& Grugel, 2015, p. 267). We discuss the nature of migrant representation by various civil society actors from Turkey and how this relates to Turkey's representation of the migration-related problems. In conclusion, we argue that there was a lack of awareness and/or indifference from Turkish civil society relating to the GFMD processes. This was due to the weakness of migrants' rights activism and hence, the migrant voice from Turkey could not be directly represented at the Forum. ${ }^{2}$

\section{The framework of GFMD and CSDs}

Although it is out of the formal UN system, the GFMD is a 'voluntary, informal, non-binding, and government-led process open to all States Members and Observers of the United Nations to advance understanding and cooperation on the mutually reinforcing relationship between migration and development and to foster practical and action-oriented outcomes. ${ }^{3}$ Initiated after the UN High Level Dialogue on Migration and Development (UN-HLD) in 2006, the GFMD has become a space in which new standards and policies for global migration governance are discussed between governments and CSOs. Thus, as well as having the objective of facilitating 'a constructive dialogue among governments' (GFMD, https://gfmd.org/process/civil-society), the GFMD also seeks to attain the input of civil society actors who are considered 'partners' and 'contributors'. Nevertheless, most of the GFMD process tends to be led by governments.

During the first meeting in Brussels in 2007, the operating guidelines were set in order to ensure continuity and support for the incoming chairs from the host countries. The chair is responsible from the preparation and implementation of that year's GFMD. The Forum also includes a troika, which consists of the past, present, and the future chairs, as well as a steering group, which is comprised of a number of governments that grant political and strategic support to the chair, and the Friends of the Forum, a consultative and informative body which is open to state members and UN observers.

The Forum's participants include policymakers from various governmental departments such as ministries of the interior, immigration, labour, foreign affairs, labour, etc., together with UN bodies, other international organizations, CSOs and academia. The officially stated aim of incorporating 
civil society is to 'include the voices and expertise' (GFMD, https://gfmd.org/process/civil-society) from the trade unions, NGO representatives, migration scholars, representatives of migrants and diaspora, and private sector. The interaction between civil society actors and governments has evolved throughout the years, and the final GFMD framework poses that civil society actors meet for two days, referred as CSDs, prior to the meeting of governments. Every year, a statement which includes the messages and recommendations from civil society is presented during the governments' meeting. Moreover, a five-hour 'common space' is organized among governments and civil society representatives. Here, a CSD representative puts forward the main recommendations from civil society and summarizes the fundamental debates from the previous two days. The common space is open to participation from all civil society delegates. ${ }^{4}$

The CSDs are organized by an international network of civil society actors. Some of these have been formed in the last couple of years during civil society actors' preparations for the GFMD such as the Migration and Development Civil Society (MADE) Network or the International Civil Society Steering Committee. Meanwhile, others are relatively older organizations at the civil society level such as the International Catholic Migration Commission (ICMC). The ICMC has been coordinating civil society activities at national, regional, and international levels, working closely with chairs with the help of the Migration and Development Programme (MADE) co-funded by the EU. With the Steering Group, ICMC plans a thematic focus for civil society during the year, as well as a set of activities including consultations with governments and the two CSDs with the collaboration of CSOs, the chair and the troika.

During the 2015 CSDs in Turkey, the International Steering Committee selected 225 civil society delegates out of 800 applications from the civil societies of 150 countries. Almost $40 \%$ of the delegates were from migrant or diaspora NGOs, a third from human rights NGOs and the remainder from development NGOs, labour organizations, academia, and the private sector. There were 82 'observers' from international organizations and UN bodies. ${ }^{5}$ Nevertheless, there are not any, officially stated, accreditation process whereby government authorities pre-screen the participating CSOs. Furthermore, there are no fees associated with attendance and the application process is fairly easy via an online application form. Yet, knowledge of the English language is necessary for proper discussions to occur during the CSDs because almost all meetings are held in English. During the CSD 2015 in Istanbul, four parallel working sessions were organized that focused on the sustainable development goals, migrants in crisis, labour rights, and diaspora.

Over time, dissatisfaction has developed on the part of participating civil society delegates who claim that CSDs and GFMD frameworks are not entirely open venues for critical voices in civil society. Thus, a parallel event to the CSDs, the People's Global Action (PGA) on Migration, Development and Human Rights, was first initiated in 2008. In line with the criticisms put forward by the PGA, we also think that the deliberative processes of global governance have demonstrated a democratic deficit. This is due to the lack of a genuine diversity of civil society actors, mainly migrants themselves. Therefore, despite some progressive efforts, there are problems of representation, participation, and accountability when it comes to the inclusion of the actual voice of social movements and NGOs in global policy frameworks. The GFMD framework has been particularly criticized for its structure and a lack of migrants' human rights claims (Schierup, Ålund, \& LikicBrboric, 2015, p. 56, see also Allund and Schierup, 2018). In this paper, we aim to analyse if the GFMD structure in general and CSDs in particular can develop to ensure the quality representation of migrants' rights. 


\section{The problem of representation}

Grillo (1985) conducted an anthropological study in urban France between 1974 and 1976 where he critically analysed the situation of migrants by focusing especially on the 'representation of problems' and the 'problem of representation'. Since his field study, a lot has changed in the politics of migration both at national and international levels. Nevertheless, Grillo's theoretical perspective on representation remains valid, and we find it illuminating for an understanding of the GFMD process in terms of the quality of migrants' representation.

Grillo (1985, p. 2) refers to 'representation' as having a certain 'perception and conception' with an 'ideological dimension'. Thus, representation concerns the ideas and beliefs of those who are representing a certain social situation embedded in a complex institutional context. Grillo poses the question of how and why the migrants' situation was viewed as 'problematic' in France, and what the role of the institutions there were in the 'representation of problems', stating:

... if there is 'representation' of problems, there is also a problem of 'representation.' The point is this: If the situation of immigrants is 'represented' as problematic - perceived, conceived, analysed, and finally handled in terms of the "problems" that immigrants pose or are believed to experience - and these 'representations' are taken into the institutional system through which policies are formulated and implemented, then we must examine who presents the 'representations,' that is, whose view is 'represented' in a political sense ... (Grillo, 1985, p. 2)

As such, any explanation of a concrete migration and migrant situation conveys a socially positioned and ideologically biased representation. Therefore, it becomes essential to pose the question who, or which institutions, are the main actors representing migrants? This provides a critical starting point for our subsequent analysis of the GFMD/CSDs as spaces where the migrant voice is supposed to be represented. In this context, it is essential to delineate the institutional character of the GFMD as a particular type of global venue compared to other venues where formal and binding decisions are supposed to be taken.

During the CSDs, civil society actors come together in order to formulate their policy goals, which are only then forwarded to governments in the common space. Yet, the GFMD structure still offers an 'invited space' (Gaventa, 2006) which facilitates the coming together of policymakers (governments) and civil society actors of various kinds. It opens numerous closed (national) spaces (i.e. the national migration policymaking space) to discussions at the global level with the involvement of civil society actors who are active at various levels (global, regional, national, and local) and with various kinds of ideologies. The essential question is to inquire into the nature of representation that takes place. And in this particular context, our attention is focused on if, by whom and how migrants are actually represented.

One significant finding of Grillo's concerning the situation of migrants in urban France is that the migrant situation is generally represented as a 'problem' by non-migrants. Moreover, representation by non-migrants takes place in institutional settings where there are generally no migrants present. As Grillo (1985, p. 267) notes: 'All too frequently, then, the immigrant voice is represented in the public arena by the French'. Therefore, migrant representation is “indirect", "processed”, or "coded"” in various institutional settings, be it private or public (Grillo, 1985, p. 280). Grillo does not dismiss the situations where migrants represent other migrants, although recognizes that these occur less frequently than the above-mentioned indirect forms of representation. Yet, these representations by migrants may also be regarded as indirect because the representing migrant speaks in the name of many others to whom he or she may not resemble at all (Grillo, 1985, 
pp. 274-275). Consequently, the presentation of migration-related 'problems' has an intrinsic problem of representation.

The GFMD structure foresees incorporating the 'voice of civil society' through the CSDs which are assumed to be represented by pro-migrant civil society actors. Yet, there appears good reason to look critically at the representation quality of the migrant voice during CSDs, given that it is mostly carried forth by non-migrants, indirectly and ideologically articulated or 'transmuted' (Grillo, 1985, pp. 277-280). However, the issue of migrants' self-representation is more complex both theoretically and empirically. First of all, it is essential to ask whether it is possible, given the character of the current global order, for migrants to actually realize their genuine self-representation. Most migrant organizations in the main receiving countries are rather weak. Being represented or self-represented does not in itself solve problems related to the global migration governance. In other words, representation does not necessarily bring political change. As argued by Gaventa (2006), having the potential to make a transformative/fundamental change in status quo depends on concerted and continuous efforts in the available institutional spaces, as well as on the type of power that the various actors possess (such as agenda setting, decision-making, etc.). The particular space reserved for civil society in the GFMD/CSDs appears to resemble what Miraftab (2004, pp. 3-4) has characterized as a heavily monitored 'invited space' in the context of which governments hold, as phrased by Gaventa (2006, p. 29), an 'invisible power' that circumscribes and 'shapes the psychological and ideological boundaries of participation'.

In the following section, we spotlight migrant self-representation in the CSDs. Yet, we do not propose an essentialist view of migrant identity that could be represented only by a migrant self. We aim to highlight that there is a problem of representation in the GFMD/CSDs, given their claim of including the 'migrant voice'. We consider the limited representation of the migrant voice a democratic deficit. Securing migrant representation does not automatically democratize the global governance of migration. It does not necessarily lead to political change or even a critical challenge to the status quo; i.e. to a 'transformative action' (Gaventa, 2006). However, we argue that once an 'invited space' (Miraftab, 2004), such as the CSDs, is set up, it is significant to look for the subordinate groups' selfrepresentation (i.e. the migrants' self-representation) and scrutinize if this representation has an effect of transformative action on the nature of space itself.

\section{The GFMD, the government and migrants: the Turkish chair}

The summer and then the autumn of 2015, when the actual forum and the CSDs were held, came to be known as the 'long summer of migration' (Kasparek \& Speer, 2015). More than a million people crossed into the EU mostly via the Greek islands from Turkey during that period (IOM, 2015). In response, many EU member states closed their borders and introduced restrictive measures against asylum seekers who were later stranded during winter in the Balkans. The situation has been described as the biggest EU migration crisis, and the border regime has become stricter since (Fiedler et al., 2017). At the time of the Forum, the EU Commission had started negotiations with Turkey for an agreement to halt these unwanted flows into Western Europe in return for aid which was initially worth three billion Euros. ${ }^{6}$ It was against this background that Turkey, as a transit country of migration, held the GFMD chair.

Although the scope of the GFMD was originally limited to the relationship between migration and development, asylum and refugee issues were eliminated from the agenda in order to avoid overlap with the work of existing UN institutions (Newland, 2012, p. 231). Notwithstanding, the GFMD's agenda has been broadened by the participating states and incoming chairs' propositions in recent 
years. As such, new and pressing issues of our times with regard to migration and development have been included, and the Forum's focus is specified through consultation with the other member states (Chikezie, 2012, p. 224). By putting the Syrian case as an example under the sub-theme of 'enhancing international cooperation on emerging issues in migration and mobility', Turkey aimed to extend the migration-development framework of previous forums to the protracted refugee situations. The chosen title for the GFMD 2015 by Turkey, 'Strengthening Partnerships: Human Mobility for Sustainable Development', implied the lack of burden-sharing among states in the international arena with regard to the Syrian refugees. Turkey called for international cooperation on this matter before and during its chairmanship (Hurriyet Daily News, 2015). To this end, Turkey underlined the importance of collaboration among states, civil society, international organizations, and the migrants themselves (GFMD, 2015a, p. 2).

This chair also coincided with Turkey's Presidency for the G-20 in 2015 and the World Humanitarian Summit in May 2016. During the preparatory processes for all these events, the UNHCR declared 2014 to be the worst year for human displacement since the Second World War. While having sheltered more than two million Syrians under its temporary protection system at that time, Turkey put special emphasis on the issue of Syrian refugees for these three events. The other sub-themes of the Forum, 'migration as a factor in development' and 'human mobility and the well-being of migrants', are also connected to this issue.

For the Forum, Turkey set three main objectives: to enhance migrant-focused migration, to recognize the development impact of migration in public policies, and to engage relevant stakeholders in strengthening the linkages between migration and development. With the first objective, Turkey aimed at integrating the views of civil society and migrants in the GFMD platform in order to direct the focus of migration management on rights, dignity, and wellbeing. The second objective was to make migration a priority at all discussions on development policies. Under this title, Turkey organized an ad hoc thematic meeting with regard to the 'Mediterranean Crisis' in Brussels on 15 July 2015 during the preparatory process. In line with the first objective, the Turkish chair situated the problem of 'irregular migration' within a broader development framework which supports the facilitation of migrants' safe and legal entry (GFMD, 2015b, p. 34). The continuing engagement of the private sector in migration issues was one of the top priorities of Turkey under the second objective. Together with Switzerland, Turkey organized a private sector meeting in Istanbul. The aim was set to understand the needs of the private sector vis-à-vis governments regarding business-friendly labour migration policies (GFMD, 2015b, p. 32). For the third objective, Turkey strongly defended the inclusion of migration in the final negotiations of the post-2015 development agenda. With the support of the G-20 Presidency, Turkey held a side event in New York while the 2016-2030 sustainable development goals were being discussed. Although it was not just the result of these efforts, the GFMD initiatives worked and migration was placed within the 2030 goals (GFMD, 2015b, p. 38).

The UN Special Representative of the Secretary-General for International Migration Peter Sutherland thanked Turkey for placing great importance on the issue of forced migration and mentioned that the notion should be extended to cover not only refugees but also displaced populations and economic migrants (GFMD, 2015b, p. 7). With the emphasis on public-private partnerships to create jobs for migrant communities (GFMD, 2015a, p. 5), Turkey aimed at extending the development framework of the GFMD to displacement and refugees. The sessions under the three roundtables emphasized the human rights of migrants, the human security of forced migrants compelled to cross borders, and access to employment opportunities, education and family unification. 
In this discourse, Turkey raised the pressing issues of the time, and set the problem for the GFMD as forced migration and migrants' inclusion into the development-migration framework. Utilizing a human rights and human security approach, the Turkish chair proposed to lift the separation between migration-development and refugee issues which was originally set for the GFMD processes. However, while praising this stand at the Forum, the government initiated negotiations for a controversial deal with the EU for the return of irregular migrants from Greece who passed through Turkey. In May 2015, the Syrian border was sealed off and the construction of a 590-kilometre concrete wall began. In early 2016, Turkey also introduced a new visa requirement for Syrian citizens. This made Syrian, and other, refugees trapped in Turkey without any future prospects because the nature of the protection offered there is temporary (Atac et al., 2017, p. 15). Rather than fully abiding to the 1951 Refugee Convention, Turkey, hence, solved the problem of burden-sharing through the financial aid of the EU in practice. In return for keeping the Syrians and other refugees away from engaging in a secondary movement towards the EU, international NGOs and states turned a blind eye to the problem of refugee protection and human rights in Turkey. Although the practice contradicted the official discourse, the problem set by this agenda could still be meditated between states and participating civil society actors/ migrants themselves at the Forum.

\section{The $\mathbf{2 0 1 5}$ civil society days and Turkish civil society}

The specific concern of this section is to analyse participation processes of Turkish civil society and the representation of the migrants' voice in the 2015 CSDs. It is a case offering insights at a critical time and place, when and where, during the times of 'migration crisis', Turkey has emerged as a significant actor in the context of the European 'migration crisis'.

\section{Pro-migrant civil society in Turkey}

The emergence of a pro-migrant civil society in Turkey is a very recent phenomenon, and the most relevant organizations have emerged since 2000. These organizations remain small in number and influence sphere (Danış \& Parla, 2009; Erdoğdu \& Şenses, 2015; Kaşl1, 2016; Özgür-Baklacıoğlu, 2006; Toksöz, Erdoğdu, \& Kaşka, 2012; Toumarkine, 2001). Various human rights INGOs have also focused on migration as a part of their activities, such as Amnesty International, the Helsinki Citizens Assembly and the ICMC, together with Turkish NGOs, such as the Foundation for Society and Legal Studies, the Association for Solidarity with Refugees, and the Association for Solidarity with Asylum Seekers and Migrants. Such INGOs/NGOs aim primarily to protect and broaden the rights of migrants by developing awareness in public opinion. They do advocacy work, and also provide social services such as basic health care, training courses, and aid in kind and cash for migrants in need (Toksöz et al., 2012, p. 111-125). In addition to human rights organizations, several looser network-type organizations have emerged during the 2000s such as the Migrant Solidarity Network and the Precarity Movement (Toksöz et al., 2012). They have the character of social movements in their infancy. And although they lack an institutionalized organization, they constitute a network of activists with a diverse range of activities such as protest movements, awareness-raising events, etc. (cf. Calhoun, 1993). Their emergence is related in particular to the forced migration of Syrian refugees in 2011. Finally, there are the migrants' self-organizations, which - relating to the definition of 'immigrant' in the Turkish legislation - refers to two distinct groups of actors. An 'immigrant' [göçmen] is officially defined as a person with a 'Turkish descent and culture' and all other non-citizens are designated as 'foreigners' [yabancı]. A considerable number of 'immigrants' have managed to 
acquire Turkish citizenship as a result of relatively favourable policies towards this group. On the other hand, the organizations of 'foreigners', such as of Afghans and Syrians, are relatively weak and have only recently developed.

\section{Turkish civil society at 2015 CSDs}

In the CSDs which took place on 12-13 October 2015, there were 21 registered delegates from Turkey. Among these, there were three academics including the authors of this paper and three representatives from an employers' union, the Turkish Confederation of Employer Associations. ${ }^{7}$ The rest of the delegates constituted a diverse range of groups. ${ }^{8}$ There were eight different human rights organizations, yet only one delegate from a migrant organization; the Izmir Balkan Migrants Culture and Solidarity Association. Thus, the 'immigrants' of Turkey only had one representative at the GFMD Turkey 2015, and the 'foreigners' were not represented through their own organizations. Regarding the loose network-type organizations, or pro-migrant social movements, there was not a single registered delegate. We understand the non-participation of network organizations as a political act on the part of these organizations. Some pro-migrant activists opted not to participate into the GFMD/CSDs as invited spaces because they consider these venues instruments of national governments' migration management.

Among the Turkish civil society delegates, there were also organizations which cannot be categorized either as human rights and migrants' organizations or network-type organizations. For example, the Turkish Red Crescent, represented by four delegates during the CSDs, is a government-organized non-governmental organization (GONGO). ${ }^{9}$ Another organization, the Children's Film and Art Association, had not had previous activities either on migrants' rights or social service provision.

In order to further assess how the migrant voice was represented during the CSDs by Turkish civil society, we conducted short interviews with five members of civil society who had been involved either in the selection or participation processes of the GFMD 2015. These personal communications occurred on 4-5 January 2017 and 15-17 November 2017. Three of the interviews were with representatives from human rights NGOs, one of which was specifically working on migrants and refugees. The other two interviews were with the activists of the Migrant Solidarity Network (MSN)/ Ankara, a network organization whose member was selected as a delegate but abstained from attending the GFMD. We asked these civil society actors to evaluate the GFMD processes and if/how they benefitted. The representative of one of the human rights organizations stated that they had not been aware of the GFMD process, its importance or influence. It was through the MIGLINK project that her organization was informed and decided to participate in the CSDs. She highlighted that the sphere of migration governance should not only be left to governments. However, she also stated that the cooperation of civil society organizations at the international level requires considerable financial power as well as human resources with a good command of foreign languages that the majority of CSOs in Turkey lack.

On the other hand, one of the MSN activists claimed that the GFMD has a structure made by states where governments do their own thing. She further stated that if they had participated, then that would mean they are legitimizing governments' policies. In addition, she made a clearcut distinction between the PGA and the CSDs. She considered her participation in the PGA worthwhile and stated that she had been informed on various important issues such as the working and living conditions of the domestic migrant workers in the Gulf States, the immense scale of migration within the African continent and the activities of American CSOs located in Mexico. On the other hand, the other activist of the MSN claimed that they should have participated in the CSDs. He 
argued that it was also meaningful to engage in opposition within the system rather than remaining outside of it and it was important to resist it with a constructive tone. He said that they could have made their voice heard without adopting the governments' language if they had participated in the CSDs.

\section{Non-representative representation}

Most migrant-receiving states of the global North have failed to opt for UN-backed, treaty-based multilateral frameworks that address current issues of international migration. This has been demonstrated by their non-ratification of the UN International Convention on the Rights of All Migrant Workers and Members of Their Families. It can be expected that GFMD-like loose-structured, extra-UN venues will prevail in the future as a result of this general unwillingness of states to embark on more formal cooperation and a binding multilateral institutional and normative framework for migration governance (Piper, 2015, p. 792). The question remains whether such venues can still be considered as spaces providing solid political opportunities for migrants and migrant rights activists for transformative action (Gaventa, 2006). Our main concern in this paper has been how the migrant voice is represented by civil society actors. We have hypothesized that if the migrants' selfrepresentation is limited, it also reduces and twists the migrant voice as such. From this perspective, we have aimed to shed light on the participation and the representation processes of Turkish civil society in the Istanbul GFMD.

Although the CSDs of the GFMD may be seen as a network of a variety CSOs and individual activists, it still appears to hold the character of a heavily monitored 'invited space', in which a conservative status quo on migration management, is firmly maintained. Migrant representation appears, at least as reflected in the Istanbul CSDs/GFMD, not to include the potential of incorporating a potent migrant voice. Therefore, contrary to claims that the GFMD is the only global platform that facilitates a dialogue between states and non-state actors (Omelaniuk, 2012, pp. 4-5), our own observations seem to confer that it remains a closed 'invited space' with the host (the governments) in firm control of the process.

First of all, the civil society actors from Turkey were not well diversified. Migrants' self-representation was particularly weak and even non-existent for the 'foreigners' of Turkey. There was only one migrant organization and this organization was not representative of millions of irregular migrants and/or refugees, but rather an organization of Balkan immigrants most of whom are already Turkish citizens. This is not to say that Balkan immigrants do not need representation; on the contrary, their participation was not only significant in itself, but also in the sense of diversifying the composition of delegates from Turkey. However, there was not even one migrants' organization that could represent Syrian refugees, Afghan asylum seekers, African migrants, and many other of Turkey's 'foreigners'. Moreover, migrants were not present as members of other types of organizations. Thus, there was an acute problem of 'mediated' and 'indirect' representation (Grillo, 1985). This is a problem for the venue's potential in democratizing migration governance, especially in terms of broadening the scope of political participation which may allow the 'ordinary immigrant' to 'speak directly and unaided in the public arena' (Grillo, 1985, p. 280). Secondly, among the 21 delegates from Turkey, only eight delegates from eight different organizations seemed to carry relatively in-depth experience with migrants that may have allowed them to represent 'the problem'. Most of these organizations, however, only focus on refugees/asylum seekers rather than all migrants. This is a general feature of migration-related civil society in Turkey that was also confirmed during the above-mentioned interviews we conducted with the participants and non-participants of CSDs. A reason for that may be 
how the Turkish Chair represented the problem in the Forum. As the biggest refugee-hosting country in the world Turkey drew attention to burden-sharing and international collaboration among states, international organizations, civil society, and migrants themselves regarding protracted refugee situations. While the EU member states marked their approach to the issue of forced migration and Syrian refugees with the 2016 EU-Turkey Deal, the Turkish government underlined the importance of the private sector's involvement in migration via a development framework in order to keep Syrian refugees under Turkey's temporary protection system.

Indeed, our observations do derive from a particular case, focused on the participation/non-participation of Turkish civil society to the 2015 GFMD and/or general state of migrant activism within Turkey, rather than being general conclusions on global migration governance and/or on the whole GFMD processes. The lack of migrant presence (migrants' self-representation) may depend on an unawareness or indifference on the part of human rights organizations in Turkey to represent the migrants' interests. More importantly, it may be the result of weak migrant organizations in the first place and a lack of alliances/cooperation between migrants' organizations and human rights NGOs in Turkey. However, what might look as a context-bound conclusion may actually reflect more general trends present in other national contexts and even a global phenomenon.

Migrants, irrespective of their status, are first all workers, and most migration issues relate to labour. Framing the Forum around forced migration and referring solely to refugees may function as a tool to hide the problems related to the integration of migrants into national labour markets. As trade unions are highly bureaucratized and slow to react to the problems of those migrants working in the informal economy (Piper \& Grugel, 2015, p. 271), we did not see either the trade union representation of migrant workers or an expected cooperation between the unions and migrants' organizations in Turkey (Gökbayrak \& Erdoğdu, 2010; Erdoğdu \& Şenses, 2015) or in most other national settings. Consequently, the Syrian refugees' problems were not discussed from the perspective of labour. Turkey's push for a migration-development framework for the Syrian case brought the inclusion of private sector partnership to the process as a sub-theme of the Forum, but not the unions or migrants' self-organizations.

Civil society's focus more on refugees rather than migrants might be reflecting the current state of civil society in Turkey where most of the funding goes to refugee issues and most Turkish NGOs working in the field depend on these external financial sources. Therefore, we recognize that our findings are bound to the Turkish context by developments and relationships. However, these findings are not uncommon in other parts of the world that also participate in global migration governance. As is argued by Sassen (2006), without meaningful localized initiatives of different groups of activists that engage in continuous multiscalar interaction, there will be no facilitative multilateralism (Betts, 2011) within global migration governance in its current restricted form. Moreover, representing the problem based on legal categorizations of migrants, such as refugees, irregular migrants, and economic migrants, is actually a general trend of current migration management, be it global or national.

In conclusion, when it comes to the potential of the GFMD for transformative action, the chair of the hosting state represents the problem within the framework of the dominant discourse, and all the roundtable discussions held under the sub-themes of the Forum depend on the agenda set by the chairing state (Rother, 2012, p. 185). Given its current structure, and without the direct representation of migrants, the GFMD appears destined to fail in facilitating a genuine dialogue between states and migrants themselves. A changing discourse and institutional practices, globally as well as nationally, appears to demand the strengthening of the migrants' own organizations and the development of a continuous dialogue and sustainable alliance-making between human rights NGOs, trade unions and the migrants' self-organization. 


\section{Notes}

1. MIGLINK (Migration and Development Civil Society in Global Governance 2014-2016) was an international research project which analysed the role of civil society in global migration governance by focusing on and comparing the empirical contexts provided by the GFMD 2014 Sweden and the GFMD 2015 Turkey. Through our participation in the 2015 Forum as civil society delegates from Turkey, we had the opportunity to interact with CSOs in Turkey and observe their positions towards the GFMD, starting from October 2014.

2. We organized a dialogue meeting in October 2014 with pro-migrant civil society actors targeted at introducing them to the GFMD processes. We invited almost all of the active members of migration-related civil society, however, only 11 CSOs actually turned up at the meeting. Apart from the ILO and IOM members, almost all other organisations that participated in the meeting, and with whom we communicated with during the invitation process, had heard about the GFMD/CSDs from us. This indifference/ unawareness may have depended on various reasons such as the lack of international links Turkish civil society organisations have with other pro-migrant national and global civil society actors. Civil society in Turkey lacks the necessary material and human resources to deepen its activism both nationally and globally (personal communication, 15-17 November 2017).

3. This quotation is from the official website https://gfmd.org with detailed descriptions of the GFMD institutional framework and its long-term development.

4. An overview of the civil society report for the 2015 Common Space is available at http://gfmdcivilsociety. org/common-space-and-chairs-report-2015/.

5. The website of the GFMD Civil Society Days (CSD): http://gfmdcivilsociety.org/gfmd-csd2015overview/.

6. The negotiations between Turkey and the EU started on 15 October 2015 when the GFMD was held in Istanbul. The EU-Turkey Action Plan was agreed later on 29 November 2015 (IOM, 2015).

7. The Turkish workers' unions appeared not to be interested in the GFMD and did not participate in the Forum.

8. These organizations are: the Association for Solidarity with Asylum Seekers and Migrants, the Research Centre on Asylum and Migration, the Association for Solidarity with Refugees, the Refugee Rights Turkey, Amnesty International Turkey, Caritas Foundation, the Human Resource Development Foundation, Support to Life, Izmir Balkan Migrants Culture and Solidarity Association, Turkish Red Crescent, Maya Foundation (Project Lift), and the Children's Film \& Art Association.

9. According to its statute, the association is autonomous and shares the general principles of the International Red Crescent and Red Cross Movement.

\section{Acknowledgements}

The authors would like to thank editors, Branka Likic-Brboric, Gülay Toksöz, and Raul Delgado Wise of this special issue as well as Carl-Ulrik Schierup for their invaluable comments on earlier drafts of this paper. The authors are also indebted to the anonymous reviewers who greatly helped them to refine the argument with their guidance and suggestions.

\section{Disclosure statement}

No potential conflict of interest was reported by the authors.

\section{Funding}

This article is a contribution to the Swedish Research Links project, 'Migration and development. What space for civil society in global governance? (MIGLINK)', with financial support through the Swedish Research Council [grant number 348-2013-6682]. 


\section{ORCID}

Nazh Şenses (D http://orcid.org/0000-0002-3473-7604

\section{References}

Ålund, A., \& Schierup, C. U. (2018). Making or unmaking a movement? Challenges for civic activism in the global governance of migration. Globalizations. doi:10.1080/14747731.2018.1446599

Atac, I., Heck, G., Hess, S., Kaşlı, Z., Ratfisch, P., Soykan, C., Yılmaz, B. (2017, 3 December). Editorial introduction. Movements, 3(2), Retrieved from http://movements-journal.org/issues/05.turkey/01.atac,heck,hess, kasli,ratfisch,soykan,yilmaz--contested.borders.turkey.migration.regime.introduction.html

Betts, A. (2011). Global migration governance. Oxford: Oxford University Press.

Calhoun, C. (1993). 'New social movements' of the early nineteenth century. Social Science History, 17(3), 385427.

Chikezie, C. E. (2012). Civil society, common space, and the GFMD. In I. Omelanuik (Ed.), Global perspectives on migration and development, GFMD Puerto Vallerta and beyond (pp. 207-227). London: Springer.

Danış, D., \& Parla, A. (2009). Nafile soydaşlık: Irak ve Bulgaristan Türkleri örneğinde göçmen, dernek, devlet. [Ethnic kinship in vain: Turkish migrants from Iraq and Bulgaria, migrant associations, and the state.]. Toplum ve Bilim, 114, 131-158.

Erdoğdu, S., \& Şenses, N. (2015). Irregular migrant labour, trade unions and civil society organisations in Turkey. In C. U. Schierup, R. Munck, B. Likic-Brboric, \& A. Neergaard (Eds.), Migration, precarity and global governance: Challenges and opportunities for labour (pp. 177-196). Oxford: Oxford University Press.

Fiedler, M., Georgi, F., Hielscher, L., Ratfisch, P., Riedner, L., Schwab, V., \& Sontowski, S. (2017, 15 April). Editorial introduction. Movements 3(1). Retrieved from http://movements-journal.org/issues/04. bewegungen/01.fiedler,georgi,hielscher,ratfisch,riedner,schwab,sontowski--umkaempfte-bewegungen-nachund-durch-europa en.html

Gaventa, J. (2006). Finding the spaces for change: A power analysis. IDS Bulletin, 37(6), 23-33.

Geiger, M., \& Pécoud, A. (2010). The politics of international migration management. Basingstoke: Palgrave Macmillan.

GFMD. (2015a). Final concept note. Retrieved from file:///Users/cavidansoykan/Downloads/gfmd_turkey2014-2015_concept_note\%20(2).pdf.

GFMD. (2015b). The report of the 2014-2015 GFMD Turkish chairmanship. Retrieved from https:/gfmd.org/ docs/turkey-2014-2015

Gökbayrak, S., \& Erdoğdu, S. (2010). Irregular migration and trade union responses: The case of Turkey. $\dot{I}_{s ̧}$, Güç: Endüstri İlişkileri ve İnsan Kaynakları Dergisi, 12(2), 89-114.

Grillo, R. D. (1985). Ideologies and institutions in urban France: The representation of immigrants. New York, NY: Cambridge University Press.

Hurriyet Daily News. (2015, 5 October). Retrieved from http://www.hurriyetdailynews.com/turkeys-erdogancalls-on-eu-to-share-refugee-burden-calls-for-no-fly-zones-89442

International Organisation for Migration. (2015). Mixed migration flows in the mediterranean and beyond. Retrieved from http://doe.iom.int/docs/Flows20Compilation202015\%20Overview.pdf 
Kaşl1, Z. (2016). Who do migrant associations represent? The role of 'ethnic deservingness' and legal capital in migrants rights claims in Turkey. Journal of Ethnic and Migration Studies, 42(12), 1996-2012.

Kasparek, B., \& Speer, M. (2015). Of hope. Hungary and the long summer of migration. Retrieved from http:// bordermonitoring.eu/ungarn/2015/09/of-hope-en/

Miraftab, F. (2004). Invited and invented spaces of participation: Neoliberal citizenship and feminists' expanded notion of politics. Wagadu, 1, 1-7.

Newland, K. (2012). The GFMD and the governance of international migration. In I. Omelanuik (Ed.), Global perspectives on migration and development, GFMD Puerto Vallerta and beyond (pp. 227-240). London: Springer.

Omelaniuk, I. (2012). Introduction: Making the connections between migration and development. In I. Omelanuik (Ed.), Global perspectives on migration and development, GFMD Puerto Vallerta and beyond (pp. 1-27). London: Springer.

Özgür-Baklacıoğlu, N. (2006). Türkiye'nin Balkan politikasında Rumeli ve Balkan göçmen dernekleri. [Balkan and Rumeli migrant associations in the context of Turkey's Balkan politics]. In S. C. Mazlum \& E. Doğan (Eds.), Sivil toplum ve dış Politika [Civil society and foreign policy] (pp. 77-117). Istanbul: Bağlam.

Piper, N. (2015). Democratising migration from the bottom up: The rise of the global migrant rights movement. Globalizations, 12(5), 788-802.

Piper, N., \& Grugel, J. (2015). Global migration governance, social movements, and the difficulties of promoting migrants rights. In C. U. Schierup, R. Munck, B. Likic-Brboric, \& A. Neergaard (Eds.), Migration, precarity and global governance: Challenges and opportunities for labour (pp. 261-278). Oxford: Oxford University Press.

Piper, N., \& Rother, S. (2014). More than remittances: Resisting the dominant discourse and policy prescriptions of the global 'migration-development-mantra'. Journal Für Entwicklungpolitik, 30(I), 44-67.

Rother, S. (2012). Standing in the shadow of civil society? The 4th global forum on migration and development (GFMD) in Mexico. International Migration, 50(1), 179-188.

Sassen, S. (2006). Territory, authority, rights: From medieval to global assemblages. Princeton, NJ: Princeton University Press.

Schierup, C.-U., Ålund, A., \& Likic-Brboric, B. (2015). Migration, precarisation and the democratic deficit in global governance. International Migration, 53(3), 50-63.

Toksöz, G., Erdoğdu, S., \& Kaşka, S. (2012). Irregular labour migration in Turkey and impact of migrant workers on the labour market. Ankara: IOM.

Toumarkine, A. (2001). Kafkas ve Balkan göçmen dernekleri. [Community organisations of migrants from Caucasus and Balkans]. In S. Yerasimos (Ed.), Türkiye'de sivil toplum ve milliyetçilik [Civil society and nationalism in Turkey] (pp. 425-450). Istanbul: İletişim Yayınları.

UNHCR. (2015a). UN High Commissioner for Refugees Antonio Guterres - Written text of speech to the UN Security Council - 26 February 2015. Retrieved from http://www.unhcr.org/news/press/2015/2/54ef66796/ un-high-commissioner-refugees-antonio-guterres-written-text-speech-un-security.html

UNHCR. (2015b). UNHCR Turkey external update. Retrieved from http://www.unhcr.org/turkey/uploads/ root/august_external_update_rev_2015.pdf 


\title{
Syrian refugees in Turkey and trade union responses
}

\author{
Seyhan Erdoğdu
}

\begin{abstract}
This article discusses trade union responses in Turkey to Syrian refugees against a background characterized by shrinking boundaries of union inclusion. The analysis is based on semi-structured interviews with trade union executives from confederations and affiliated trade unions in textile and garment, construction, local public services, commerce and metal sectors, and focus group discussions with union members in the workplace. At the confederation level, Turkey's trade union movement generally adopts a solidaristic rhetoric regarding Syrian refugees and attempts to shape trade union policies accordingly. However, there is little articulation with sectoral unions and the work-place level. Sectoral unions who do not encounter Syrian workers in the workplace do not place refugee issues on the trade union agenda. Instead union-level responses foreground the negative effects of Syrian refugees on the labour market while humanitarian considerations remain secondary. Unions demand formal employment of Syrian refugees should be ensured to eliminate these problems to prevent competition with local labour leading to a race to the bottom regarding pay and working conditions. Members at the workplace level oppose Syrian refugees with an exclusionary and somewhat hostile attitude, alleging that they damage the labour market, urban security and social life.
\end{abstract}

\section{Introduction}

This article discusses trade union responses in Turkey to Syrians under temporary protection against a background characterized by shrinking boundaries of union inclusion in a segmented labour market with Syrian refugee labour forming the lowest strata together with the rest of the undeclared migrant workers from different nationalities.

The research angles in this paper are restricted to discussion of two questions: First, what are the defining characteristics of the trade union attitudes and actions towards Syrians under temporary protection in Turkey at the confederal, sectoral and membership level and which factors shape these characteristics. Second, are there differences in these attitudes and actions; if so, how these differences can be explained.

These questions will be taken up in an analysis based on semi-structured interviews with trade union executives from three different trade union confederations and affiliated trade unions in textile and garment, construction, local public services, commerce and metal sectors, and focus group discussions with union members in the workplace and screening of trade union congress decisions and publications. ${ }^{1}$ 
After a brief discussion on the theoretical and historical aspects of trade union solidarity with migrant workers, for a better understanding, some information on Turkish trade unions and their response to irregular labour migration prior to the Syrian refugee crisis will be provided. Then, information on the Syrians under temporary protection in Turkey which we think contributes to analysing the attitudes of the trade unionists will be presented. Next, in search of answers to our research questions, the findings of our 2017 research on trade union attitudes and actions towards Syrian refugees in Turkey will be analysed. In the conclusion we summarize our findings around our research questions.

\section{From solidarity with migrant workers in the nineteenth century to the restrictive policies of the twentieth century}

Historically, trade union solidarity with migrant workers peaked during the period when skilled 'journeymen' migrated across Europe, at a time when there were no national regulations limiting labour mobility. During this period, many of the first generation of union leaders met trade union and socialist ideas during their travels as journeymen. National trade unions supported skilled migrants, even providing them with identity cards. This solidarity was consolidated by the work and life experiences of skilled migrants. According to Danish data for example, during the 1870s and 1880 s, $15-65 \%$ of the work force in various professions comprised skilled migrant workers. In Germany, before the First World War the estimated number of migrant workers was 1.5 million (Logue, 1980).

As modern industry rapidly spread across European countries, the industrial working class grew and the nature of labour migration began to change. Now, semi-rural, unskilled workers from Italy, Poland and Russia began looking for work in agriculture, mining and factories in Austria, Germany and France. These semi-rural workers were deprived of the trade union and professional experience of skilled workers and, as they were not unionized in their own country, they did not respond to efforts to organize in unions in the countries they worked in. By the end of the nineteenth century, the policy of trade union solidarity among skilled migrants was transformed into protectionist or restrictive policies towards migration. For example, the International Secretariat of National Trade Unions defended limiting migrant labour and called for a prohibition on immigration during strikes and industrial crises (Dreyfus, 2000). After the First World War, trade unions chose to prevent competition from migrant workers by securing national legislation to restrict immigration. Nation states were to decide who comes to the country and the circumstances in which they come (Zincone, Penninx, \& Borkert, 2011).

In the course of the twentieth century, most trade unions in developed capitalist countries pursued restrictive approaches to migrant workers on the basis of job protectionism (Briggs, 2001; Castles, 1990; Zincone et al., 2011). Especially during economic crises, these unions established new alliances with state authorities to encourage restrictive immigration policies. The international trade union movement as represented by the International Confederation of Free Trade Unions ${ }^{2}$ reflected the attitude of the national trade unions by not promoting worker mobility in its policy documents; at best, it suggested equal labour and social rights for regular migrants (ICFTU, 1983, 1999). Even during the growth and prosperity years of the post war period the unions were concerned about the alleged threat of migrants to wages and working conditions of their members (Freeman, 1979). The discourse on internationalism was in many cases overshadowed by the priority given to the concept of citizenship. 
While advocating restrictive immigration policies was the general trend, many unions displayed inclusionary approaches towards migrants after they became settled in the country concerned as in the case of German unions playing an important role in the subsequent integration processes of guest workers of 1960s and their families (Penninx \& Roosblad, 2000). The French unions tried to bring foreign workers into the unions despite the strong hostility at the shop-floor level (Castles, 1990). In the 1960s and 1970s, Danish unions exerted much effort to organizing immigrants into unions and unemployment insurance schemes (Wrench, 2004).

In seeking answers to the question of what determined the specific responses of trade unions towards migrant workers, variables affecting trade unions' attitudes and practices towards migration and migrant labour have been explored in various comparative or country specific studies.

In their classic comparative study of trade union attitudes toward migrant workers, Penninx and Roosblad (2000) identify four major variables determining relations between trade unions and regular and irregular migrant workers: the power that trade unions have in society and in national socioeconomic decision-making; economic and labour market conditions; social aspects such as public discourse, institutional arrangements, legislation, and institutional actors like national authorities, civil society organizations, and political parties; and the characteristics of immigrants and public perceptions. In another comparative study of trade unions in Germany, Spain and South Korea, Agtas, Sauviat, and Amler (2007) found that the trade union type, based on historical and structural circumstances is the key factor determining trade union attitudes towards migrant workers and business unionism, political unionism, social dialogue unionism and corporatist unionism were associated with lower enthusiasm for organizing migrant workers, while social movement unionism and syndicalism led to more interest. Hardy, Eldring, and Schulten (2012) compare trade union strategies towards migrant workers from three sectors in the UK, Norway and Germany and conclude that trade union responses to these migrant workers are shaped by the complex interplay of national industrial relations systems, sectoral dynamics, European Union (EU) regulation and the agency of individual trade unions.

Country-specific and comparative studies show that during economic stagnation, especially recession, unemployment increases and negative societal attitudes toward migrant workers strengthen (Beets \& Willekens, 2010). Outside periods of economic crisis, if there are concerns about unemployment in a particular sector, trade unions may take a restrictive stand against labour migration.

An important variable affecting the unions' approach to migrants is their legal status. Regarding irregular migrants, unions generally advocate three policies: preventing irregular migration, protecting the fundamental rights of irregular migrants and regularizing them (Watts, 2002). Which of these policies gets prioritized depends on current labour market conditions and union characteristics.

The structure of the union itself is another important variable. Internal factors shaping union attitudes towards migrants include ideology, sector structure (public-private; labour intense-capital intense; local market-export market), financial power, level of bureaucracy, political influence and role in social dialogue mechanisms (Agtas et al., 2007). In some countries, unions are represented in trilateral structures for migration management, which enables them to play a direct role in local management of migration. In some countries, unions play a role in regularizing temporary labour migration and recruiting workers. There are some cases where union membership in one country is recognized by another country (Betts, 2011).

Recent studies show that trade unions are more inclusive towards migrants, with newly emerging organizational models based on the inclusionary efforts of certain unions in both North America and Europe. While unions' approaches based on citizenship and legality continue to limit their 
imagination on solidarity with migrant workers, there are increasing numbers of examples of unions being instrumental in organizing irregular migrant workers (Ford, 2004; Lüthje \& Scherrer, 2001; Milkman, 2000, 2006; Ness, 2005; Watts, 2002). Research on Southern Europe has shown that trade unions have adopted a cooperative and positive position towards immigration, supporting regularizations, offering political support for immigrants' rights claims and providing various services (González-Enríquez \& Triandafyllidou, 2009). Marino, Penninx, and Roosblad (2015), revisiting the comparative approach of Penninx and Roosblad (2000), argue that changing migration patterns and policies, and changes in labour markets and industrial relations have driven trade unions towards more inclusive policies. In a quantitative 14 country analysis of union members' attitudes towards immigrant workers Gorodzeisky and Richards (2016), concludes that, in the majority of countries analysed, unionized workers are likely to express lower levels of objection to admitting immigrants into society.

Nevertheless, in a world where labour is still not free to move, it seems too early to declare that an alternative imagination of solidarity with migrant workers, whether regular or irregular, has emerged despite much rhetoric on inclusiveness.

\section{Trade unions in Turkey and their response to irregular labour migration}

In Turkey, trade unions are organized nationally in different branches of activity, with three major trade union confederations. The biggest confederation, TÜRK-İş, the Confederation of Turkish Trade Unions, was established in 1952. DİSK, the Confederation of Progressive Trade Unions, was established in 1967 by a group of unions that split from TÜRK-İŞ. HAK-İş, The Confederation of Rights Trade Unions, was established in 1972. TÜRK-İŞ has 33 affiliates from different branches of activity (882,496 members); DİSK has 21 (141,490 members) and HAK-İ̧ has 22 (447,930 members) (Çalışma ve Sosyal Güvenlik Bakanlığı [ÇSGB], 2016).

After the 1980 military intervention in Turkey and subsequent neoliberal transformation, trade unions in Turkey lost significant power, in both membership and political influence. The current unionization rate for registered workers is only 11.5\% (ÇSGB, 2016), and even lower if unregistered workers are taken into account. One-third of unionized workers are in the public sector. Women form only a minority of union members and are almost non-existent in union management. Overall, the Turkish union movement focuses on improving remuneration and working conditions while having limited influence on economic and social policies. As the boundaries of union inclusion have contracted due to the drop in unionization rates and loss of power, solidarity has also shrunk to its practical level of union membership. Meanwhile, Turkish unions have failed to reach out to unorganized sections of the working class, most of them maintaining instead their centralized, bureaucratic structures.

Since the mid-1990s Turkey, a country long known as a 'sending' country, witnessed an ever increasing inflow of irregular migrant workers exacerbating the informalization of the economy and the precarization of work in the most vulnerable sectors of a segmented labour market. Economic uncertainties and poverty in the former socialist countries; wars and political unrest in neighbouring countries; Turkey's geographical position as a transit region between east and west; rigid migration policies and stricter border control in the European countries and poor implementation of Turkish legislation related to irregular migration are the factors that nurtured this increase. The widespread nature of informal employment in Turkey makes it possible for irregular migrant workers to get absorbed by informal sectors where wages lower than legal minimum, irregular and even non-payment of wages; long working hours, absence of social security; 
impossibility of unionization; no protection in terms of occupational health and safety are common features.

However, despite the ever-increasing presence and the plight of migrant workers in Turkey, labour migration has not found its way onto the agenda of the country's trade unions, as revealed by the findings of two field studies conducted by this author (Erdoğdu \& Şenses, 2015; Gökbayrak \& Erdoğdu, 2008; Toksöz, Erdoğdu, \& Kaşka, 2012). Both studies were based on semi-structured interviews with trade unionists at confederation, trade union and branch levels, chosen by purposive sampling. The 2012 findings replicate the 2008 research results, with no major change in trade union attitudes of regarding irregular migrant workers. All three confederations and affiliated unıons both at central, sectoral and work-place level have lenient attitudes towards migrant labour based on humanitarian considerations. However they neither actively protect nor organize migrant workers, whether regular or irregular, nor play a role in determining migration management policies. The policies of the trade unions towards migrant workers can best be desribed as solidarity in words, indifference in deeds.

The phenomenon of irregular migrant work in Turkey which started in the mid-1990s has entered a new phase after 2011 with the Syrian refugees coming to Turkey en masse, creating urban refugee cities and entering the labour market as low-skilled, low-paid informal workers. With this turn in the migration history of Turkey, while the solidaristic discourse at the confederal level is preserved, hitherto lenient attitude of the trade unions towards migrant labour at the work-place level turned to negative.

\section{Syrian refugees in Turkey ${ }^{3}$}

Inflow of refugees to Turkey, sharing a $911 \mathrm{~km}$ long border with Syria, started right after the outbreak of civil war in Syria in 2011. Having already reached crisis proportions in 2013, the refugee flow became a seemingly irreversible immigration crisis by the end of 2015. By April 2017, the official figure for Syrian refugees had reached 2,992,562, constituting 4\% of Turkey's population (Directorate General of Migration Management, 2017).

Turkey's Disaster and Emergency Management Authority, which has been coordinating the country's response to the Syrian refugees, has housed close to 260,000 Syrian nationals in 26 temporary shelter centres to address their basic needs (AFAD, 2016). These refugee shelter centres are located in 10 cities close to the border region. Whereas in the world as a whole, the proportion of refugees living in urban areas is 60\% (UNHCR, 2017, p. 55) $92 \%$ of Syrians under temporary protection in Turkey live in urban areas outside the refugee camps overwhelming urban host communities and trying to make a living by engaging in informal jobs.

Turkey applied an 'open door policy' and a de facto 'temporary protection' regime to the Syrian Refugees until the adoption of Turkey's new Law on Foreigners and International Protection in April 2013, which came into full force in April 2014. Later that year, in October 2014, the adoption of the Temporary Protection Regulation finally meant that Turkey's existing de facto 'temporary protection' practice had a proper legislative basis. In January 2016, the long-expected 'Regulation on Work Permit of Refugees under Temporary Protection' was issued, which specified conditions and restrictions on work permits for foreigners under temporary protection. Despite the adoption of the 'Regulation on Work Permit of Refugees under Temporary Protection', no progress has yet been made in transferring Syrian refugees into registered employment.

The impact of Syrian refugees on Turkey's labour markets, social life and social expenditure has been dramatic. Approximately 650,000 refugees are estimated to be employed, overwhelmingly 
informally, and mostly in the agriculture, construction, textile and apparel sectors, and in small establishments in manufacturing and services (INGEV, 2017). Being at the lowest end of the informal sector, Syrian refugees including children work for wages lower than the legal minimum; face irregular and even non-payment of wages; long working hours. They have no social security coverage; no protection in terms of occupational health and safety and other basic practices relating to working life. Their informal status keeps them away from existing mechanisms of complaint and thus reproduces these adversities. There is a wide range of research activity on the impact of Syrian refugees on the Turkish labour market and societal relations. Studies about the economic and labour market impact of Syrian refugees in Turkey's border region cities have produced mixed findings (Akgündüz, van den Berg, \& Hassink, 2015; Carpio \& Wagner, 2015; Ceritoğlu, Gürcihan-Yüncüler, Torun, \& Tümen, 2017; Konuk \& Tümen, 2015). Local people, however, have extremely negative perceptions about the effects of Syrian refugees on the economy, social spending and the labour market. An ORSAM (2015) survey found that local interviewees in cities hosting Syrian refugees perceive a strong link between the presence of Syrian refugees and job losses, declining wages, increased risk of dismissals, higher food prices, increased housing rents, lower quality of health services, declining quality of education and increased internal emigration. Field reseach on social reactions to Syrian refugees shows that, in parallel with an increased number of refugees and a growing urban refugee phenomenon, earlier tolerance for Syrian refugees was replaced by discontent or, in some cases, hostility (Erdoğan, 2014, 2017; Erdoğan \& Ünver, 2015; Navruz \& Çukurçayır, 2015).

\section{Findings of the 2017 study on trade union responses to Syrian refugees in Turkey}

In tandem with our previous studies of 2008 and 2012 on trade union responses to migrant labour in Turkey, this current study is based on semi-structured interviews conducted with trade unionists from the confederation and sectoral trade union level, chosen by purposive sampling. The sample consists of the three main confederations in Turkey, namely TÜRK-İŞ, DİSK and HAK-İŞ, as well as unions affiliated to these confederations. The selected trade unions organize workers in the textile and garment, construction, local public services, commerce, food and metal sectors. Sixteen semi-structured face to face interviews were held with the trade union representatives, three being at the Confederation level. To learn the union members' views, two focus group interviews were held with workers in work places in the metal sector in Gebze, a town in western Turkey, where the proportion of Syrian refugees of the urban population is $1.75 \%$, and workers in the public construction sector in Urfa, a city in south-east Turkey, where the proportion of Syrian refugees is 21.67\%. Trade union publications and General Congress Reports were also reviewed to support the interview findings.

We found no significant discursive differences among the three trade union confederations in Turkey in their approach to Syrian refugees. Adhering to a solidaristic trade union position, they all support the government's open door policy, which they regard as unavoidable for humanitarian reasons. Although they have different views on the government's foreign policy regarding Syria, they generally remain supportive of the open-door policy despite a persistent increase in refugee numbers. What they find unacceptable is that EU countries unilaterally decided to diverge from EU common practices to reduce the number of asylum seekers and, in the case of some EU countries, closed their borders. Besides their critical approach to migration policies adopted by European countries, informal trade union discourse also refers to the role of 'imperialist policies leading to civil war in Syria' as the root cause of Syrian refugee crisis and the need to stop wars. The confederations' humanitarian approach is also seen in their participation in humanitarian aid campaigns carried out for Syrian 
refugees. All three confederations favour regulations to ensure the inclusion of Syrian workers in the labour market through registered employment on equal pay and equal working conditions with local workers.

TURK-IS, which is a coalition of nationalist, conservative and social democratic unions, formulated its position regarding Syrian refugees in its Presidents' Council of 2014:

TÜRK-İS Presidents' Council welcomes that humanitarian aid is provided to those who take refuge in Turkey, foremost to those coming from our bordering neighbour Syria. However, it is necessary to be careful and meticulous in terms of making their stay permanent, giving identity cards and work permits to avoid problems later on. It should be ensured that unregistered employment and unemployment do not become even more widespread, and that wage levels will not be further reduced. (TÜRK-İş, 2015, p. 15)

\section{One TÜRK-İŞ executive stated that Syrian refugees}

should work in registered jobs, benefit from the same rights as Turkish citizens; so that tomorrow there will be no job brokery. If you oppose the employment of Syrian refugees, tomorrow they will go and work in so-called under-the-stairs jobs; employers will impose cheap labor on collective bargaining tables.

The left-leaning confederation DİSK issued the following remarks regarding Syrian refugee workers in the concluding statement of its 15th General Assembly, held in 2016:

We will continue to work on the basis of class fraternity for all refugee workers, especially Syrian refugee workers, who have become part of the Turkish working class, in order to ensure that they benefit from all rights, particularly access to public services, the right to work and organize on equal terms.

The statement also emphasizes that policies such as lower insurance premiums for Syrian refugees should never be considered and practices making the Syrian workforce more attractive for employers will simply create a new source of cheap labour which may lead to serious social problems (DISKK, 2016).

HAK-İŞ which is mainly conservative, made the following statement about refugees, including Syrians, in its decisions of the 13th General Assembly, convened in 2015:

Feasible and sustainable national and international policies should be developed for asylum seekers who are forced to leave their countries for economic, political and social reasons ... HAK-İS draws attention to the problems caused by different languages, cultures and lifestyles between asylum seekers and local people. For this reason, it emphasises the importance of activities for the harmonization of asylum seekers with society. (HAK-İş, 2015b)

Even though the Syrian refugee crisis has played an important role in reshaping Turkey's migration management policies the issue was not discussed in the national tripartite bodies. Trade unions are not included in the migration related advisory boards under the General Directorate of Migration Management. This may be explained by the limited political power of the trade unions.

In summary, we can say that all three confederations endorse the government's open-door policy concerning Syrian refugees despite concerns about the negative effects of the large number of refugees on the labour market. All three confederations support regulations that will provide registered employment for Syrian refugees under equal working conditions with local workers in order to reduce the negative labour market effects. While class solidarity is highlighted in the discourse of DİSK, TÜRK-İŞ’s discourse emphasizes possible negative effects on the local labour market and 
HAK-İ̧s's discourse stresses an understanding of integration that conforms to the government's foreign and refugee policies.

In all three confederations, trade union actions towards the Syrian refugees are extremely limited. They have produced some publicationss regarding the refugee issue (DISK, 2015; HAK-İŞ, 2016; Uğraş, 2016) and have sent some humanitarian aid. HAK-IS has provided an EU-supported vocational training programme to a group of 20 refugees through a project called 'Social Integration of Refugees Through Vocational Education' (HAK-İŞ, 2015a).

Affiliated sectoral trade unions constitute the second organizational level in the Turkish trade union structure. Syrian workers are almost non-existent in unionized workplaces so the only point of contact for union members with Syrian workers is in urban spaces. Given that more than three million Syrian people now live in Turkish cities, trade unionists, like other local people, regularly encounter Syrian refugees in social environments. Like local informal workers, Syrian refugees remain outside the organizational inclusion line of trade unions, which some trade unionists attribute to the characteristics of the unionized sectors while others link it to the characteristics of union jobs. As one trade unionist in the metal sector put it,

Syrians do not work the workplaces where we are organised in the metal sector. The metal sector generally employs skilled vocational high school graduates. Not suitable for refugee employment. However, we hear some subcontractors are employing Syrians as home workers to assembly electrical outlets.

In fact many Syrians are informally employed in the metal sector in small and medium enterprises where there is no trade union; outsourced and sub-contracted jobs and even home based assembly of electric sockets. But this sector is also the one where first cases of formal and even unionized Syrian workers can be seen though their number is small. Within the total 195.000 members of the Metal Union of Turkey (TÜRK METAL) there are 25 Syrian members, most of whom are in Kocaeli. The company that these workers are employed is a medium size unionized moulding plant and formal employment of Syrians may be attributed to the fact that moulding work is not preferred by domestic workers. The Steel Workers Union) ÇELİK-İ̧̧ Union says they also came across 12 registered Syrian workers employed by a firm in an Organized Industrial District in İstanbul. The enterprise is unionized and Syrian workers will become members of ÇELİK-İŞ after their testing period.

In the services sector employment of Syrians are limited to small shops where there are no unions. One executive of a trade union organizing in supermarkets reported that, 'in our supermarket sector, the employees should speak proper Turkish as they deal with customers. They should have at least a high school graduation. Occupation groups need to be certified. Syrian refugees don't fit into this picture.'

In Turkey, the media have widely reported on Syrian refugees working in 'under-the-stairs' textile and clothing sweatshops. Garment workshops employing many unregistered Syrian workers and Syrian children aged 8-10 years are well-known sights. However, these workers have no contact with unionized textile and garment workers and their unions.

We are mostly organised in the institutionalised textile and garment firms producing for international brands. For this reason, Syrian workers do not work in our workplaces. Local companies that manufacture for international brands do not want to lose their contracts by employing unregistered refugee workers because of the control mechanisms of international firms.

However, while Syrian refugees may not be working in the visible first tier of the supply chain, union executives are unsure about employment conditions further down the supply chain. 
There are tiers in the supply chain which are out of sight. The parent companies usually work with one company. The company that receives the order has his subcontractor; and this may go on to several more subcontractors down in the supply chain. The supply chain goes down, even passing beyond workshops to homes. Control down there is not possible. ${ }^{4}$

In the construction sector $36 \%$ of workers are unregistered and the unionization rate calculated over both registered and unregistered workers is $2.2 \%$. Nearly all of the unionized workers work in public establishments, and trade union organization in private construction sector is almost nonexistent. The executive of one union organized mainly in the public construction states that none of the workplaces in which his union is organized employ Syrian workers.

Syrians are mostly employed as day laborers in small construction sites. They may also be employed by some subcontracting firms. It may be the case of, for example, a construction company gives the plastering work to a sub-contractor who may be employing Syrians or Afghans.

In some cities where the Syrians live intensively, it seems that they have formed separate 'cheap labour markets' as a way of providing labour for construction works (Kaygisız, 2017). Fifty-nine of the 96 refugee workers who lost their lives in work place accidents in 2016 are Syrian with 37 deaths of refugee workers occurring in the construction sector (İşçi Sağlı̆̆ ve İş Güvenliği Meclisi, 2017).

Bakeries are among workplaces in food industry where Syrian refugees are employed commonly. Contrary to the situation in other sectors, in some bakeries where the bakeries branch of the Food and Auxiliary Workers' Union of Turkey (TEKGIDA-İ̧) is organized, informal Syrian workers are employed to do the unskilled jobs. In bakeries where the union is not organized the number of Syrian workers is much more and this has its negative effect on unionization efforts. In spite of insistent complaints to authorities by the union, undeclared Syrian labour in bakeries cannot be prevented.

An exceptional situation in which the Syrians under temporary protection came into contact with the unionized labour force and with the trade unions took place in Gaziantep and Adana in the framework of the 'cash for work' project, which was funded by the German International Cooperation Agency covering the period of July 2016-January 2017. Within the scope of the project, 500 Syrians in Gaziantep Metropolitan Municipality and 200 Syrians in Adana, Seyhan Municipality were employed in the Park, Garden and Green Areas Departments. The union organized in the municipality states that Syrian workers in these programmes are employed for short periods and cannot become union members.

Those unions that have not encountered Syrian refugees in their workplaces have not developed any policy concerning them, instead regarding the issue as a general policy area covered by the confederations. All the unionists we interviewed stated that they did not adopt any general congress decision on Syrian refugees, and that the issue had not appeared on the agenda of the union presidents' board. They did not take any solidarity actions with Syrian workers other than sending humanitarian aid materials on rare occasions, and they had received no request for contact from the refugees themselves. However, since the January 2016 adoption of the Regulation on Work Permits for Refugees Under Temporary Protection, these unions have begun to consider the possible effects of Syrian refugees on unionized sectors. Nevertheless, one year after the regulation, they still have not felt the need to engage in special work in this regard, as the registered employment of Syrians has remained extremely limited.

Regarding union documents, there are limited numbers of informative articles and other materials about Syrian refugees (Ela, 2016; Öz İplik-İş Sendikası, 2016). However, Syrian refugee problems are not covered as a separate topic in union educational materials. According to union 
executives, refugee problems are excluded from the union's agenda because they are not seen as a priority for trade union activities.

Although low-wage informal Syrian labour is currently employed in micro or small enterprises rather than in firms where unionized workers are employed, employers use the presence of informal Syrian labour to counter union demands during collective wage negotiations. Hence, all the union executives argue for the formalization of Syrian labour to prevent such threats. One common complaint expressed by union leaders concerns ineffective labour inspection to identify unregistered Syrian employment. Public authorities seem to tolerate firms' employing Syrians informally.

Although union leaders say that Syrian refugees depress wages and working conditions, they still approve of the open-door policy applied to Syrian refugees. There is also a consensus that Syrians under temporary protection should only return to their country if they so wish.

We have very high unemployment. But we should not blame Syrian refugees for our problems. America moved some stones in Syria and three million people came here. They work in Turkey, they have jobs, they marry their children here and they stay if they want to. Returning to Syria, it must be their decision.

In summary, our fieldwork results show that affiliated unions have not yet placed refugee issues on the trade union agenda. Union-level responses focus on the negative effects of Syrian refugees on the labour market while humanitarian considerations remain secondary. Unions demand that, in order to overcome these adverse effects, formal employment of Syrian refugees should be ensured so that they do not compete with local labour in a race to the bottom. Like the confederations, unions seem to accept that Syrian refugees are here to stay in Turkey.

At the workplace level, there is an exclusionary and occasionally hostile attitude towards Syrian refugees, in contrast to the rhetoric of solidarity at the confederation and, to a lesser degree, union level. The first reason for such attitudes is the adverse effects of informal Syrian refugee employment on Turkey's labour market, which is also expressed at the level of union administrations.

When we asked union executives about the attitude of union members in the workplace towards Syrian refugees, they all agreed grassroots' attitudes were very negative. For example, one unionist described the reactions of union workers in the textile sector as follows:

In fact, textile workers see Syrian workers as a potential danger. Not skilled, but unskilled workers are upset. Are we to be laid off, will they subcontract our work to a workshop employing informal Syrian labour? As the number of refugees increases, the uneasiness also increases.

One trade union education expert says that union members at the workplace level approach Syrian refugees with prejudice and hostility:

As a trade union educator I tell them about the root causes of the refugee problem, and I say that Syrian workers, as part of the working class, are victims of this crisis. But the workers are not looking at it in terms of class brotherhood but only in terms of their influence on their daily lives. In some border towns with large Kurdish and Arab ethnic local populations, the relative tolerance of workers to Syrian refugees can only be on ethnic grounds. Workers of Kurdish origin can become more supportive of Kurdish refugees. Local Arab workers show more sympathy to Arab refugees. Islam does not emerge as a major axis of solidarity in workers' attitudes towards Syrian refugees. Positions in the world of labour, i.e. class solidarities, are completely ignored.

In our focus group interviews with members in workplaces, union members although they are of different political opinions declared their strong disapproval of government's open-door policy. Concerns regarding security and social cohesion were as pronounced as concerns regarding negative labour market effects of Syrian refugees. Exclusionary and sometimes hostile attitudes were also 
evident. The rhetoric emphasized in this regard is to claim that Syrians fled to Turkey instead of fighting to defend their homes, land or families. The following is repeated by many: 'We fought to the last for our country in the war of liberation. Our grandfathers struggled with imperialism and did not leave these lands. Syrians have abandoned their homeland instead of fighting.'

These workers also strongly criticize EU policies on Syrian refugees, Turkey's 2013 readmission agreement with the EU and the 2015 Joint Action Plan.

Europe is very sensitive when it comes to human rights, but when it comes to refugees, it does not defend their rights. They treat Turkey like a dumping ground. Our people here are worthless, their people are valuable. They want to take the qualified Syrians, the doctors, the engineers; the unqualified ones, they want to send them back to us. They say, let us give you money, visa exemptions so on ... The politicians are negotiating these deals. They live in the better parts of the city, seeing the Syrian refugees while they are begging or collecting paper. They settle the refugees in our neighborhoods. They are sealing a monetary bargain on our backs while we are suffering all the trouble here. I mean the politicians.

Union members do not support policies to include Syrian refugees in the labour market. The general belief is that they work for low wages and take the jobs of the local workforce. Even the 'jobs' of local beggars are taken by Syrians. It is thought that unregistered work, which is already widespread in Turkey, will spread even more, and that the secondary labour market, which is already segmented, will become further fragmented, with Syrians forming the lowest segment due to their lack of skills and 'unsuitable' work ethic.

The workers' negative reactions to Syrian workers also apply to Syrian businessmen and other high income groups who took refuge in Turkey's major cities, bringing their financial assets during the first phase of the civil war. This was so pronounced that there were frequent comments on how villas in Sapanca, a touristic region in Turkey, were being bought up by Syrians, and that rich Syrians were living luxurious lives in Istanbul. Syrian small business owners are also considered as competitors with local small businesses.

Union members also prejudicially compare the work performance of ethnically Turkish immigrants from Bulgaria and the Balkans to Syrian refugees, despite never actually encountering them in their workplaces. Thus, whereas they have no complaints about these Bulgarian and Balkan immigrants because they are 'hardworking' and 'disciplined', Syrians are seen as 'lazy' and 'lacking business ethics'.

The second dimension of the reaction of union members to the Syrian refugees is a profound sense of cultural difference. Language is one important factor that strengthens this sense of cultural difference. Syrians are also perceived as people with a different way of life, culturally distinct from Turks. One worker expressed his strong reaction to the Syrian refugees by saying that 'I cannot think of working side by side with them on the assembly line'. None of the workers responded positively to the question of whether their shared religion provided a certain cultural closeness with Syrian refugees.

The third dimension of the union members' reaction to Syrian refugees concerns security issues. One aspect of this is that there may be extensions of different Syrian terrorist organizations among Syrian refugees. Another aspect is the social conflicts that emerge with Syrian refugees living in communities and establishing their own internal solidarity. One common complaint is that 'Syrian refugees are involved in crimes such as violence, theft, smuggling and prostitution, they disrupt the social morals and social peace.' The fact that there have been conflicts between the local population and Syrian refugees in various Turkish cities, and the frequent media coverage of these fights, increase these urban security concerns. 
Finally, union members are strongly opposed to social spending on Syrian refugees. Common objections included claims like

Turkey has its own poor, they should get help before the Syrians; local people cannot get medical services because of Syrians in the hospitals; and scholarships are given to Syrian university students while our children are in need of financial support.

In sum, the rhetoric of unionized workers about Syrian refugees is far from expressing solidarity; in fact, it is exclusionary and even somewhat hostile. They oppose the government's open-door policy on the grounds that Syrian refugees damage the labour market conditions for local people, and that their presence causes security problems and social unrest. There is also strong resentment about the EU's refugee policies. The reactions of union workers in this regard are not different from society in general (Erdoğan, 2014). Although the majority of Syrian refugees are Sunni Arabs, this has not encouraged any perception of proximity based on religion or sect. The labour market effects and social issues seem to be the equally strong determinants behind the exclusionary attitude at the work place level.

\section{Conclusion}

Turkey became a 'migrant receiving' country from the mid-1990s and trade unions in Turkey faced the issue of irregular migrant labour employed under very poor working conditions with low wages. Trade unions both at the central and the work-place levels had a lenient attitude towards migrant workers based on humanitarian considerations but did not include migrant workers in their trade union agendas.

After 2011 with the Syrian refugees coming to Turkey en masse, creating urban refugee cities and entering the labour market as low-skilled, low-paid informal workers, the phenomenon of irregular migrant work in Turkey has entered a new phase. With this turn in the migration history of Turkey, while the solidaristic discourse at the confederal level is preserved, hitherto lenient attitude of the trade unions towards migrant labour at the work-place level turned to negative.

There are no significant differences between the three trade union centres concerning their response to the Syrian refugee labour.

Ideology doesn't seem to be a variable shaping union responses to Syrian refugees. Despite their ideological divergencies, all three confederations have a solidaristic discourse at the confederal and to a lesser extent at the sectoral level. This can be explained partly by the trade union culture of solidarity which in time becomes an independent element with its own internal dynamics for the maintenance of trade union activities (Logue, 1980) and partly by the defining role of the open door policy of the government as the main institutional actor in migration policy which is inevitably endorsed by the trade unions on humanitarian grounds.

The labour market conditions is an important variable shaping the policy response of trade unions. All three confederations together with their affiliated sectoral unions express concern about the negative effects of the large number of Syrian refugees on the labour market. They support the inclusion of Syrian workers in the labour market however through registered employment on equal pay and equal working conditons with local workers and call for effective implementation of labour laws and regulations. Feeling the pressure in their sectors, affiliated unions foreground the negative effects of Syrian refugees on the labour market while humanitarian considerations remain secondary.

Unions are not active figures, whether in the formulation of the migration policies of the country or in organizing and supporting migrant workers. Sectoral trade unions rarely coming across Syrian refugee workers in enterprises they are organized, don't feel the need to develop any special policy in 
this regard and consider the issue as a policy area that should be addressed by their confederations. One factor which explains this lack of action is the limited power that trade unions have in society and in national socio-economic decision-making. Trade unions in Turkey lost significant power, in both membership and political influence during the neo-liberal transformation of Turkish economy. They don't have the institutional capacity to be active figures regarding migrant workers. ${ }^{5}$ The trade union type is another variable behind this lack of action. Trade unions in Turkey are mainly organized in the public sector or in bigger private sector enterprises where the employment of Syrian workers is exceptional. Syrian workers employed informally in small enterprises remain outside the organizational inclusion line of trade unions as in the case of local informal workers.

While we see a convergence of policies between the confederations and sectoral unions, articulation between central union structures and the work-place level is lacking. Members at the workplace level oppose Syrian refugees with an exclusionary and somewhat hostile attitude, alleging that they damage the labour market, security and social life. Union members strongly oppose the government's open door policies and allowing Syrians to join the labour market. Culturally, they almost build an imaginary wall between themselves and the refugees. This exclusionary attitudes can be explained by two sets of variables: First is the economic and labour market conditions. Syrian workers easily join the labour market as the lowest stratum of unregistered employment, alongside Turkey's sizable irregular local labour force. Union members are deeply worried about the negative impact of the refugee labour on the employment, wages, working conditions and bargaining power of local labour. Social spending on Syrian refugees has created a perception in the union members that they are competing with refugees for limited resources for housing, education, health and social assistance. Second set of variables relates to social aspects. The sheer number of Syrian refugees coupled with their settlement in working class districts of urban spaces creates a distinct set of cultural difference in the union members who share these spaces with the Syrians. Union members, guarding their relatively secure and stable conditions do not share the positive attitudes expressed at central union structures.

\section{Notes}

1. I am grateful to the trade union executives and members who spared their time to share their views, experiences and suggestions with me.

2. In 2006 ICFTU merged with the World Confederation of Labour to form the International Trade Union Confederation.

3. Turkey applies a geographical limitation to the 1951 Refugee Convention and non-Europeans are not allowed to apply for refugee status in Turkey. Syrian nationals who came to Turkey due to events in Syria after 28 April 2011 are provided with temporary protection and are not officially considered as refugeees.

4. For a survey on Syrian refugees in Turkish garment supply chains, see Business and Human Rights Resource Centre (2016).

5. Turkey took over the Chairmanship of the Global Forum on Migration and Development (GFMD) as of July 1st, 2014, causing expectations that Turkish trade unions, facing the enormous challenge of irregular migrant labour, would actively participate in Civil Society Days and become critical contributors to the agenda. However, despite the intensive efforts of a team of researchers from Turkey on GFMD and civil society, trade unions were almost non-existent in the 2015 GFMD process.

\section{Acknowledgements}

I would like to thank the co-editors Raul Delgado Wise and Branka Likic-Brboric of this special issue as well as Carl-Ulrik Schierup for their invaluable comments on earlier drafts of this paper. I also thank the anonymous reviewers who contributed to the refinement of the paper with their suggestions. 


\section{Disclosure statement}

No potential conflict of interest was reported by the author.

\section{References}

AFAD. (2016). Turkey response to the Syrian crisis. Retrieved from https://www.afad.gov.tr/en/2601/TurkeyResponse-to-Syria-Crisis

Agtas, Ö. B., Sauviat, L., \& Amler, B. (2007). Why not organising? Trade unions and precarious migrant workers in Germany, South Korea and Spain. Retrieved from http://www.global-labour-university.org/fileadmin/ master_theses/Germany/MA_Thesis_ozge_beate_luciole.pdf

Akgündüz, Y. E., van den Berg, M., \& Hassink, W. (2015). The impact of refugee crises on host labor markets: The case of the Syrian refugee crisis in Turkey (IZA Discussion Paper No. 8841). Retrieved from http://ftp.iza. org/dp8841.pdf

Beets, G., \& Willekens, F. (2010). The global economic crisis and international migration: An uncertain outlook. Vienna Yearbook of Population Research, 2009, 19-37.

Betts, A. (Ed.). (2011). Global migration governance. Oxford: Oxford University Press.

Briggs Jr., V. M. (2001). Immigration and American unionism. New York: Cornell University Press

Business \& Human Rights Resource Centre. (2016). Syrian refugees in Turkish garment supply chains. Retrieved from https://businesshumanrights.org/sites/default/files/160131\%20Syrian\%20Refugee\%20Briefing\% 20FINAL.pdf

Castles, S. (1990). Labour migration and the trade unions in Western Europe. Centre for Multicultural Studies, University of Wollongong, Occasional Paper 18, 1990, 19. Retrieved from http://ro.uow.edu.au/ cmsocpapers/17

Çalışma ve Sosyal Güvenlik Bakanlığı [Ministry of Labour and Social Security]. (2016). Temmuz İşkolu İstatistiklerinin Konfederasyon ve Bağımsız Sendikalara Göre Dağılımı [Distribution of July 2016 Industry Statistics by Confederation and Independent Trade Unions]. Retrieved from https://www.csgb.gov.tr/ media/3577/2016_temmuz_01.pdf

Carpio, X. V., \& Wagner, M. (2015). The impact of Syrians refugees on the Turkish labor market. Retrieved from http://documents.worldbank.org/curated/en/505471468194980180/The-impact-of-Syrians-refugees-onthe-Turkish-labor-market

Ceritoğlu, E. H., Gürcihan-Yüncüler, B., Torun, H., \& Tümen, S. (2017). The impact of Syrian refugees on natives' labor market outcomes in Turkey: Evidence from a quasi-experimental design. Retrieved from http://www.tcmb.gov.tr/wps/wcm/connect/7b999ec4-0b4a-4779-af7d-3971df7f7b52/wp1705.pdf?MOD= AJPERES\&CACHEID=ROOTWORKSPACE7b999ec4-0b4a-4779-af7d-3971df7f7b52

Directorate General of Migration Management. (2017). Retrieved from http://www.goc.gov.tr/icerik6/ temporary-protection_915_1024_4748_icerik

DİSK. (2015). DİSKAR. Issue 4. Retrieved from http://disk.org.tr/wp-content/uploads/2015/09/DiSKAR_4. SAYI-KAPAKLI.pdf

DİSK. (2016). DİSK 15. Genel Kurulu Sonuç Bildirgesi [DİSK 15th general congress declaration]. Retrieved from http://disk.org.tr/2017/03/disk-15-genel-kurulu-sonuc-bildirgesi/

Dreyfus, M. (2000). The emergence of an international trade union organization 1902-1919. In M. van der Linden (Ed.), The international confederation of free trade unions (pp. 26-72). Bern: Peter Lang.

Ela, E. D. (2016). Mülteciler Geldi, Hoş mu Geldi [Refugees came, are they welcome]. TÜRK-METAL, April Nr. 201, 30-32.

Erdoğan, M. (2014). Syrians in Turkey, social acceptance and integration research. Retrieved from http://www. hugo.hacettepe.edu.tr/HUGO-REPORT-SyriansinTurkey.pdf 
Erdoğan, M. (2017). Urban refugees from 'detachment' to 'harmonization' Syrian refugees and process management of municipalities: The case of Istanbul. İstanbul: Marmara Belediyeler Birliği Kültür Yayınları.

Erdoğan, M., \& Ünver, C. (2015). Perspectives, expectations and suggestions of the Turkish business sector on Syrians in Turkey. TİSK-HUGO. Retrieved from tisk.org.tr/wp-content/uploads/2016/01/goc-rapor-ing.pdf.

Erdoğdu, S., \& Şenses, N. (2015). Irregular migrant labour, trade unions and civil society organizations in Turkey. In C.-U. Schierup, R. Munck, B. Branka Likic-Brboric, \& A. Anders Neergaard (Eds.), Migration, precarity and global governance challenges for labour (pp. 177-196). London: Oxford University Press.

Ford, M. (2004). Organizing the unorganizable: Unions, NGOs and Indonesian migrant labour. International Migration, 42(5), 99-119.

Freeman, G. P. (1979). Immigrant labor and racial conflict in industrial societies: The French and British experience 1945-1975. Princeton: Princeton University Press.

Gökbayrak, Ş, \& Erdoğdu, S. (2010). Irregular migration and trade union responses: The case of Turkey. İş, Güç: Endüstri İlişkileri ve İnsan Kaynakları Dergisi, 12(2), 89-114.

González-Enríquez, C., \& Triandafyllidou, A. (2009). Introduction: Comparing the new hosts of Southern Europe. European Journal of Migration and Law, 11, 109-118.

Gorodzeisky, A., \& Richards, A. (2016). Union members' attitudes towards immigrant workers: A 14-country study. European Journal of Industrial Relations, 22(1), 23-38.

HAK-İŞ. (2015a). Mesleki eğitim yoluyla mültecilerin sosyal entegrasyonu projesi [Social integration of refugees through social integration]. Retrieved from http://www.hakis.org.tr/icerik.php?sayfa=25

HAK-İŞ. (2015b). HAK-İS 13. Genel Kurul Kararları [HAK-İŞ 13th general congress decisions]. Retrieved from http://www.hakis.org.tr/haberler.php?action=haber_detay\&id=1093

HAK-İŞ. (2016). Report best practices of integration of Syrian migrants to employment market of Turkey. Retrieved from http://www.hakis.org.tr/uploads/files/goc-raporu-en-oy.pdf

Hardy, J., Eldring, L., \& Schulten, T. (2012). Trade union responses to migrant workers from the 'new Europe': A three sector comparison in Norway, Germany and the UK. European Journal of Industrial Relations, 18 (4), 347-363.

ICFTU. (1983). Report of thirteenth congress. Brussels: Author.

ICFTU. (1999). Migration and globalisation: The new slaves. Brussels: Author.

İNGEV İnsani Gelişme Vakfi. (2017). Syrian refugee livelihood monitor - summary assessment. Retrieved from http://ingev.org/wp-content/uploads/2017/07/Syrian-Refugee-Livelihood-Monitor-Summary-Assessment. pdf

İşçi Sağllğı ve İş Güvenliği Meclisi. (2017). 2016 yılında en az 96 göçmen işçi yaşamını yitirdi [In 2016 at least 96 migrant workers lost their lives]. Retrieved from http://www.guvenlicalisma.org/index.php?option=com content\&view=category\&id=149\&Itemid $=236$

Kaygısız, İ. (2017). Suriyeli Mültecilerin Türkiye işgücü Piyasasına Etkileri [The Effects of Syrian Refugees on the Turkish Labour Market]. İstanbul: Friedrich-Ebert-Stiftung.

Konuk, B. B., \& Tümen, S. (2015). Immigration and prices: Quasi-experimental evidence from Syrian refugees in Turkey. Retrieved from http://www.tcmb.gov.tr/wps/wcm/connect/TCMB+EN/TCMB+EN/Main+Menu/ PUBLICATIONS/Research/Working+Paperss/2016/16-01

Logue, J. (1980). Toward a theory of trade union internationalism. Kent, OH: Kent Popular Press.

Lüthje, B., \& Scherrer, C. (2001). Race, multiculturalism and labour organizing in the United States: Lessons for Europe. Capital \& Class, 25, 141-171.

Marino, S., Penninx, R., \& Roosblad, J. (2015). Trade unions, immigration and immigrants in Europe revisited: Unions' attitudes and actions under new conditions. Comparative Migration Studies, 3, 1, 178. doi:10.1007/ s40878-015-0003-x.

Milkman, R. (2000). Immigrant organizing and the new labor movement in Los Angeles. Critical Sociology, 26, 59-81.

Milkman, R. (Ed.). (2006). Organizing immigrants: The challenge for unions in contemporary california. Ithaca, NY: ILR Press.

Navruz, M., \& Çukurçayır, M. A. (2015). Factors affecting changes in perceptions of Turkish people towards Syrian refugees. International Journal of Social Sciences, IV(4), 75-85.

Ness, I. (2005). Immigrants, unions and the new US labor market. Philadelphia, PA: Temple Unions Press.

ORSAM. (2015). The economic effects of Syrian refugees on Turkey: A synthetic modelling. Ankara: ORSAM. 
ÖZ İPLİK-İş Sendikası. (2016). Öz İplik-İş Sendikası 'O' isimli kısa film [Öz İplik-İş union short film 'O']. Retrieved from https://www.youtube.com/watch?v=_HPiWMtlDB0

Penninx, R., \& Roosblad, J. (2000). Trade unions, immigration and immigrants in Europe, 1960-1993: A comparative study of attitudes and actions of trade unions in seven west European countries. Oxford: Berghahn Books.

Toksöz, G., Erdoğdu, S., \& Kaşka, S. (2012). Irregular labour migration in Turkey and situation of migrant workers in the labour market. Ankara: International Organization for Migration.

TÜRK-İŞ. (2015). Başkanlar Kurulumuz Toplandı [Meeting of union presidents]. TÜRK-İS Dergi, 402, 15.

Uğraş, G. (2016). Suriyeli Mülteci Krizine Sendikal Bakış [Trade union view on Syrian refugee crisis]. TÜRK-İŞ Dergi, 407, 55-59. Retrieved from http://www.turkis.org.tr/TURK-IS-Dergisi-407-sayi-d1197

UNHCR. (2017). Urban refugees. Retrieved from http://www.unhcr.org/urban-refugees.html

Watts, J. (2002). Immigration policy and the challenge of globalization. Unions and employers in unlikely alliance. Ithaca, NY: Cornell University Press.

Wrench, J. (2004). Trade union responses to immigrants and ethnic inequality in Denmark and the UK: The context of consensus and conflict. European Journal of Industrial Relations, 10(1), 7-30.

Zincone, G., Penninx, R., \& Borkert, M. (Eds.). (2011). Migration policymaking in Europe: The dynamics of actors and contexts in past and present. Amsterdam: Amsterdam University Press. 


\title{
Angry birds of passage - migrant rights networks and counter- hegemonic resistance to global migration discourses
}

\author{
Stefan Rother (1)
}

\begin{abstract}
The past decade has seen the emergence of a global migration governance architecture. But while - unlike other 'objects' of global governance migrants are able to speak for themselves, only limited participatory space has been reserved for them in global processes. In reaction to this glaring democratic deficit, migrant organizations try to challenge and bring about change in the nascent global migration regime. Drawing from neo-Gramscian approaches, this paper analyses the various political spaces where a cluster of migrant rights organizations and 'networks of networks' express and organize resistance and counter-hegemonic discourses to the current paradigms within global migration governance. Particularly, this article focuses on two spaces of organizing: the International Assembly of Migrants and Refugees (IAMR), held by the International Migrants Alliance (IMA), and the Churches Witnessing With Migrants (CWWM) wherein temporary labour migrants, often referred to as 'birds of passage', form a large part of their constituency.
\end{abstract}

\section{Introduction}

Demonstrations and gatherings are no unusual sight at the Brandenburg Gate in Berlin, but the 28th of June 2017 still stood out in this regard - with two different, if not juxtaposed, demonstrations for migrants' rights taking place on the very same day. The occasion for both events was the tenth Global Forum on Migration and Development (GFMD) which was taking place in Berlin. The evening gathering was held under the theme 'Breaking down Walls: Prelude at the Gate' and based on an 'open invitation for GFMD civil society participants to share a short poem, song, story, reflection, dance on the theme of "Walls"'. It was thus mostly a meeting of registered delegates from the GFMD Civil Society Days (CSD) which were to start the following day under the heading 'Safe, Orderly and Regular Migration Now: Mechanics of a Compact Worth Agreeing to'. As the title implied, the discussion of the two-day civil society meeting and one-day 'Common Space' with government representatives focused on the deliberations for the Global Compact for Migration (Wee, Vanyoro, \& Jinnah, 2018). The major challenge was seen to be the inclusion of a rights-based approach to migration in the Global Compact. Many of the participants were affiliated with the Global Coalition of Migration (GCM), a global umbrella network of migrants' rights organizations. This network follows an inside-outside approach (Rother, 2009) by participating in the main event while, at the same time, organizing a more inclusive parallel process, the 'Peoples' Global Action on Migration, Development and Human Rights’ (PGA) (Schierup, Ålund, \& Likić-Brborić, 2015). 
The morning gathering also took place in front of the Brandenburg Gate but was situated in a different political space than the evening one; that is, from those present at the 'Migrants and Refugees Speak Out Street Event', hardly anybody would participate as a GFMD delegate in the days to come. Instead, many of the activists would join the 'International Assembly of Migrants and Refugees 2017' (IAMR7- Berlin) organized by the International Migrants Alliance (IMA) after the demonstration, and many had been present at the Churches Witnessing With Migrants 8th International Consultation (CWWM8) the days before. These gatherings were being held in what I consider alternative political spaces to the 'official' fora in which global migration governance was being negotiated, and previous gatherings of the PGA and the IAMR have been compared as a 'tale of two tactics' (Rother, 2013). In this article, however, the focus is on the cluster of organizations and gatherings around the IAMR which acts as an 'outsider by choice' (Rother, 2009) and hence might be more likely to act as a force of counter-hegemonic resistance.

When Michael J. Piore published his hugely influential book 'Birds of Passage: Migrant Labor and Industrial Societies' in 1979, one of his innovations was to put structural and institutional forces at the centre stage (Fine, Milkman, Iskander, \& Waldinger, 2016, p. 775) as noted: 'One can better understand migration by ignoring income differences and recognizing instead that people are rooted in a social context in ways that other commodities are not' (Piore, 1979, p. 8). While the main focus of Piore's book is on the economic and labour market aspects of migration to the USA, the political dimension is also addressed in a section on the organizations of migrants. Here, the argument that 'temporary migrants do not have a long-term interest in the community [which] ... is bound to affect their interest in political participation' (Piore, 1979, pp. 109-110) is made, and that the temporary character of migration generates a leadership problem due to the high turnover of people.

While the latter challenge still holds true in many cases, a lot has changed in the context of migrant organizing. Piore writes about a shift from temporary migration to permanent settlement in the US context, but until today, in many other regions of the world, such a change in status is largely unachievable. Here, contract-based (or irregular) temporary migration is the rule for the so-called lower-skilled workers and many of them are set in a circle of 'permanent temporary migration' (Rother, 2017, p. 961). As such, organizing reaches beyond the realms of the nationstate to the transnational, and even up to the regional and global levels. The social context and intersecting forms of discrimination and exploitation of these labour migrants have received much broader attention in the past decades, including the observation that 'Birds of Passage are also Women ...' (Morokvasic, 1984). Furthermore, there has been increasing resistance against the commodification of migrant labour, seen as a landmark of capitalism. Specifically, many migrant activists have become very angry birds of passage indeed, as illustrated by this report from the Churches Witnessing With Migrants (CWWM) meeting in in Mexico 2010, with its consultations on and depictions of:

[...] the sorry plight of migrants and uprooted peoples. Emotions expressive of solidarity were palpable; but so was outrage. Migrant's stories replete with narratives of abuse, exploitation and assaults on their dignity and violations of their human rights were rendered together with songs of freedom, hope and empowerment. Mexico was empathetic, and the unity statement showed it: "With forced migration, human beings are turned into expendable commodities, treated as cogs in a machinery to gain profits for the rich and powerful countries. Their humanity is squeezed dry by intensifying exploitation, xenophobia, racism and repression. We are saddened by this social and economic reality". (Bautista, 2017, p. 6)

This leads one to pose the question: How does this expression of outrage translate into political action and what is it up against? In order to answer this question, it is necessary to understand the 
hegemonic and counter-hegemonic discourses on migration. In this regard, I draw from a neoGramscian perspective with modifications regarding concepts of civil society and the agency of marginalized grassroots movements, discussed in the next section. Thereafter, I apply this neo-Gramscian perspective to analyse the IMA's strategies and prospects for establishing a counter-hegemonic movement. As a first step, I aim to identify the underlying norms of the current 'historic bloc' with regard to migration. This is followed by an analysis of the mechanisms used to uphold these norms, with a focus on international institutions. Particularly, I discuss the war of position of the IMA, IAMR and CWWM against the current migration management paradigm in terms of the alternative norms and strategies employed. Finally, this is contrasted with the inside-outside approaches of the competing GCM network - are these more successful in mainstreaming alternative norms or rather a case of trasformismo (see below); i.e. being co-opted?

The analysis is based on the extensive fieldwork which includes participant observation in various global fora and counter-events (at all GFMDs since 2008, the ILO, the UN-HLD, the WSFM, the WTO MC9 ...), partially documented in blogposts as immediate impressions, ${ }^{1}$ as well as interviews and document analysis.

\section{Theoretical approach}

'The task of changing world order begins with the long, laborious effort to build new historic blocks within national boundaries' was the conclusion of Robert W. Cox's essay on 'Gramsci, Hegemony and International Relations' (Cox, 1993, p. 65). This suggested starting point notwithstanding, neo-Gramscian perspectives include a transnational dimension. In particular, Stephen Gill (1990) focuses on 'transnational capitalist class formation' (see also Globalizations Special Issue Vol. 10. No. 5) and Cox's (1981) nébuleuse 'transnational managerial class' which consists of dominant actors in global capitalism and state officials. There is also acknowledgement of a transnational working class, but a specific group - if not class - that is transnational by its very nature has so far received surprisingly little attention in neo-Gramscian analysis: Migrant workers and refugees.

Migrant workers and refugees may be considered transnationally marginalized groups (lacking recognition by their country of origin and/or destination as well as support by the international system), but can nonetheless strive for achieving agency as well as advocate for political and social transformation. Hironori Onuki (2007, p. 128) has criticized the 'elitist bias of the neo-Gramscian approach', arguing that a neo-Gramscian focus on elitist agency:

[...] presupposes migration workers as passive recipients of state policies and/or as victims of geographically uneven and fragmented development of capitalist economy. It also overestimates the hegemony of transnational capital by diminishing the possibility for transformation within world order, too often leaving questions regarding counterhegemonic forms of resistance for future research.

This article aims to analyse such counter-hegemonic forms of resistance on a transnational and global level, using the International Assembly of Migrants and Refugees (IAMR), held by the IMA, and the Church Witnessing With Migrants (CWWM) as a case study. It proposes an analytical framework of their strategies and tactics by drawing from a neo-Gramscian perspective while avoiding the pitfalls of its focus on elitist agency by choosing the grassroots as the main level of analysis.

In order to analyse counter-hegemonic discourses, one obviously has to first analyse the current hegemony. Cox's understanding of hegemony is markedly different from mainstream International Relations theories in that it is not understood as the dominance of one powerful nation state, but rather as a consensual mode of transnational socialization. A 'historic bloc' is characterized by a 
condensation of class interests and the implementation of a specific mode of production beyond national borders. World hegemony thus is a combination of three structures - social, economic and political. It is further 'expressed in universal norms, institutions and mechanisms which lay down general rules of behaviour for states and for those forces of civil society that act across national boundaries - rules which support the dominant mode of production' (Cox, 1993, p. 62). For Gill and Law (1989), this mode of production is characterized by a transnational regime of accumulation and an associated hegemony of transnational capital. Onuki (2007, p. 128) furthers that the effects on migration are manifold: Labour-intensive production plants have been constructed in the Global South based on the transnational relocation of production, thereby disrupting traditional production and reproduction processes and leading to male and female emigration.

In light of the neoliberal restructuring of the capitalist world economy, a counter-hegemonic historic bloc would have to be equally transnational in structure and build on cross-sectoral alliances (Gill \& Law, 1989). These networks are associated with the concept of civil society, but some reconceptualization of the Gramscian approach might be needed. Gramsci used the term 'civil society' to describe 'all the institutions which helped to create in people certain modes of behaviour and expectations consistent with the hegemonic social order' (Cox, 1993, p. 51) such as the church, the educational system or the press. In the age of transnational advocacy networks and global civil society, one might come to a different definition. However, in the context of migration, civil society is by no means automatically a counter-hegemonic actor. As such, this paper discusses whether these actors really challenge the current hegemonic social order or if they rather contribute to upholding it by working within the existing frameworks and paradigms (see below). This is a critique repeatedly expressed by the IMA towards more moderate/pragmatic migrants' rights networks, but I discuss whether it might also apply to the IMA itself.

The mechanisms to uphold dominant norms such as top-down migration management and categorizing migrants into distinctive classes from 'low-skilled' to expats, as well as applying different control measures and granting migrant rights are expressed through national policies, but also through international organizations. Cox (1993, p. 62) lists five features of such institutions as follows:

[...] (1) they embody the rules which facilitate the expansion of hegemonic world orders (2) they are themselves the product of the hegemonic world order (3) they ideologically legitimate the norms of the world order (4) they co-opt the elites from peripheral countries and (5) they absorb counter-hegemonic ideas.

The process through which elite talent from peripheral countries and potentially counter-hegemonic ideas are co-opted into international institutions and made consistent with current hegemonic doctrine is called trasformismo. Besides individuals and their ideas, the same observation might be made regarding civil society networks which are being increasingly granted a 'place at the table' in international organizations, but risk being co-opted in the process, mainstreamed through accreditation and funding requirements, etc.

Gramsci described the strategies for counter-hegemony as war of movement and war of positions. While the former was achievable in the Russian revolution, in Western Europe, with its more developed and diverse civil society, a war of position was more feasible as it slowly builds up the social foundations of a new state. Cox (1993, p. 53) describes the implications of such a strategy as follows: 'It means actively building a counter-hegemony within an established hegemony while resisting the pressures and temptations to relapse into pursuit of incremental gains for subaltern groups within the framework of bourgeoisie hegemony'. Trying to change the system from within, however, carries 
the risk of co-optation. And, Evans and Ayers (2006, p. 305) argue that even the seemingly counterhegemonic 'idea of universal human rights has been coopted by the prevailing (neo)liberal consensus in support of processes associated with capitalist globalization'.

\section{The norms and institutions of global migration governance}

To understand the current hegemony with regard to migration, we have to identify the underlying norms, institutions and mechanisms. Although the literature on global migration governance is growing (Betts, 2011a; Brickner, 2013; Koslowski, 2011; Kunz, 2013), there has been limited mention of the normative implications or frameworks (Betts, 2011b, p. 23; Düvell, 2011, p. 91), and only occasional debate on the underlying norms per se. Schierup, Munck, Likić-Brborić, and Neergaard (2015) discuss the normative dimensions such as human rights norms, different interpretations and the obstacles to implementation. Some authors also argue that the underlying norms regarding the way global migration is governed are the conceptualization of people as sedentary and the upholding of the state system itself (Kalm, 2008; Soguk, 1999). Other norms might be 'the orderly movement of people', a top-down management approach to migration and, as the IMA would claim, the commodification of labour. These migration-specific norms are linked to more fundamental norms regarding the modes of production, neoliberal economics, gender norms and the relationship between centre and periphery (Wallerstein, 2004). The migration and development paradigm with its promise of triple-win-effects (for countries of origin and destination, as well as the migrants themselves) is also linked to narrow Western-centric conceptions of development (Piper \& Rother, 2014).

While migration has long been seen as the exclusive domain of the nation state, the past two decades have seen a proliferation of global dialogues and fora. These have been accompanied by a plethora of reports from institutions such as the World Bank which focus particularly on harvesting the developmental potential of migration. On the plus side, these reports have highlighted the positive aspects of migration and helped to make multilateral talks on the issue possible; on the downside, many reports have reduced their conception of development to the role of financial remittances and ultimately led to the depolitization of migration (Pécoud, 2015).

One notable exception is the International Labour Organisation (ILO), a UN specialized agency with a tripartite structure, bringing together representatives of states, employers and trade unions, while allowing space for input from civil society actors such as migrant representatives. The ILO proposes including migrant workers in its decent work agenda and argues that 'labour migration costs must be seen in the broader context of employment and labour markets - not merely through the narrow lens of remittance transactions' (Cholewinski \& Tayah, 2015, p. 1). In contrast, the International Organisation for Migration (IOM) is by self-definition a 'non-normative' organization and remains so after having achieved the status of 'related organisation' to the UN system in 2016. It is not without irony, then, that the IOM has been instrumental in upholding several norms underlying the current hegemonic discourse on migration. One of them is expressed in the organization's slogan: 'Managing Migration for the Benefit of All'. As such, it has been debated how beneficial this managing paradigm has been and for whom (Ashutosh \& Mountz, 2011; Geiger \& Pécoud, 2010). Nonetheless, the concept has gained wide prominence in government and policy circles, painting migration as a problem/challenge that can nevertheless be managed in a technocratic, top-down manner. 'Management', however, leaves little room for participation, and migrants and their movements are thus seen as policy objects with hardly any agency of their own (Piper \& Rother, 2012, p. 1737). 
A similar observation can be made in processes such as the Global Forum on Remittances, Investment and Development (GFRID). In the forum, organized by, among others, the International Fund for Agricultural Development (IFAD), which is a specialized agency of the United Nations, and the World Bank, migrants themselves are rarely involved. In the June 2017 meeting, IOM New York Director Ashraf El Nour made the telling statement that 'Countries must maximize the financial contribution of migrants by integrating them as key agents of development'. This could be interpreted in the way that the goal is to get the maximum amount of remittances out of migrants by using a development agent discourse. Similarly problematic is the overly repeated but under-defined notion of circular migration. While it is enthusiastically praised by policy-makers and think-tanks such as the Migration Policy Institute (Newland, Agunias, \& Terrazas, 2008), it remains unclear whether in these instances circular migration is not just used as a fancy term for temporary migration schemes, with no option for a permanent right to abode (Wickramasekara, 2011).

Thus, one could argue that in the recent discourses on migration and development, management and circular migration are just a benign way of upholding what Cox calls world hegemony or the 'historic bloc': Migrant labour as a cheap commodity in the neoliberal mode of production that has to be controlled/managed with institutions such as the IOM upholding the underlying norms. Schierup, Ålund, et al. (2015, p. 50) have described the current context as one in which 'precarization of work and citizenship has generated a globally mobile reserve army of labour forged by austerity programmes'. These dominant discourses are in conflict with norms upheld by migrants' rights organizations such as a rights-based approach to all stages of the migratory process, making migration a choice not a necessity, analysing the root causes of migration such as unequal economic policies and acknowledging migrants as actors in their own right (Piper \& Rother, 2012).

However, the migration and development 'mantra' (Kapur, 2003) has also opened up spaces for migrant civil society voices and counter-discourses. The most prominent manifestation of this narrative is the GFMD. Its origins lie in the first major debate of migration in the UN; the 'High Level Dialogue on Migration and Development' (UN-HLD) in 2006. No consensus could be reached on providing a permanent space for deliberations on the topic within the UN system; hence a process was created outside of it: The GFMD as an informal, non-binding and state-led process. The first forum took place in 2007 in Brussels and has been followed up by annual meetings, except for 2013, when a second HLD was held at the UN.

One could see the GFMD as a further process upholding the existing hegemony as discussed above, and this holds true in particular for some of the initial meetings. Nevertheless, there has also been some movement. Starting with the Mexican meeting in 2010, civil society has been granted more space within the process including a 'common space' for - initially very cautiously regulated dialogue with the government representatives (Rother, 2012). To a degree, the GFMD has served as a space for states' socialization towards more cooperative behaviour - or at least a general openness towards it (Rother, 2018). When the UN General Assembly agreed in 2016 to negotiate a Global Compact for Migration within two years, this could be seen as a partial result of the groundwork laid out by the GFMD process (no doubt made more urgent by the 'migration (policy) crisis' of the previous years).

This trust-building exercise extended in some ways to migrant civil society. In particular, host governments of predominantly receiving states supported more inclusion of its representatives. Moreover, the chair of the 2016 meeting in Dhaka, Bangladesh even spoke out for inclusive migration governance instead of control or management. Civil society representatives also claim that they have been able to mainstream parts of their agenda into the GFMD deliberations. Indeed, issues such as human rights, gender, irregular migration or climate-induced migration that were 
taboo at the initial meetings now feature regularly on the GFMD agenda. There is still a strong tendency, though, to hand over the solution to labour market mechanisms and recruitment agencies.

The question if this can be considered real progress or a case of trasformismo - where a counterhegemonic discourse is still very much needed - has led to markedly different responses among migrant civil society groups. In an assessment of the second GFMD in Manila, I described these approaches as 'inside-outside' versus 'outsiders by choice' (Rother, 2009), and this tale of two tactics still holds true today, as could be witnessed by the two separate gatherings described at the beginning of this chapter. The term 'outsiders by choice' refers to the deliberate decision to stay outside of these global governance processes in order to avoid co-optation and provide legitimacy to the hegemonic discourses that are reproduced and enforced there. ${ }^{3}$ These actors believe that a counter-hegemonic discourse cannot be upheld within the system but must be started from the outside. In the following section, I analyse the main processes that help create these spaces for advocacy and which are closely interlinked.

\section{The IMA, IAMR and CWWM - creating spaces for a counter-hegemonic movement?}

In the world of civil society and NGOs, one has come to terms with a plethora of acronyms. The main acronyms used in this section refer to three interrelated processes that have formed over the past decade in a somewhat consecutive order. IMA stands for the International Migrants Alliance, 'the first-ever global alliance of organizations of grassroots migrants, refugees and displaced peoples' ${ }^{\text {' }}$ that had its founding assembly in Hong Kong, SAR, the 15th to 16th of June 2008. This is a network that is active year-round and addresses a wide number of issues on the global, regional and transnational levels. In contrast, IAMR refers to a specific gathering, the International Assembly of Migrants and Refugees. It was first organized in autumn 2008 by the newly founded IMA and related organizations as a counter-conference to the second GFMD in Manila. ${ }^{5}$ Finally, the CWWM is 'an international platform for advocacy and forthright action focused on global migration, particularly forced migration in all its forms ${ }^{6}$ which also started as a consultation in relation to the GFMD in Manila. Thus, all three processes were initiated within a short timeframe and have overlapping participants, yet have distinctive agendas.

The close relations to the GFMD meetings - with regard to time and place - show that, while the activists contest its agenda, the forum (unintentionally) provides them with an opportunity to organize their own counter-space to challenge the involved governments and international institutions. Attention is heightened during the GFMD meetings (at least in the migration 'scene' mass media still takes fairly little notice of the forum). And because the GFMD can be seen as symbolic for current migration discourse, it also provides a point of reference around (or against) one can organize.

\section{IMA and IAMR}

The IMA functions as the permanent structure of the movement. It acts as a global umbrella organization or 'networks of networks'. The founders distance their alliance from what they consider 'NGOism' (Hsia, 2009) and declare the IMA to be the first genuine grassroots organization that is run by and not for migrants: 'For a long time, others have spoken on our behalf. Now we speak for ourselves' (IMA, 2008, p. 1) This statement is in line with a Gramscian approach that 'traces the various phases subaltern groups go through on the way toward realizing the need to learn to speak for themselves, to create their own autonomous organizations' (Buttigieg, 1995, p. 29). 
By its own account, the IMA has more than 120 member organizations from more than 30 countries worldwide. Organizations by Philippine migrants constitute by far the biggest group, in part due to the country being among the top five source countries for migrants and a long tradition of domestic political organizing and mobilization which has spilled over to the migrant communities abroad. To stress the self-organizing dimension of the network, only grassroots mass organizations, unions or alliances of migrant organizations and their families can become regular members. Institutions, committees on migrant workers of a local trade union, networks and programmes that deal with providing services to migrant workers can apply as associate member to the Alliance (IMA, 2008, p. 133). Furthermore, researchers and other supporters can obtain observer status. There is also a close connection, including calls for solidarity, with the International League of People's Struggle (ILPS), chaired by Jose Maria Sison, the founder of the Communist Party of the Philippines who resides in exile in the Netherlands and is linked to most Filipino organizations within the IMA.

The keynote address of the IMA founding assembly was given by the late Irene Fernandez, the renowned founder and director of the Malaysian human rights organization Tenaganita. In her speech, she elaborated on the anti-imperialist orientation of the IMA: ${ }^{7}$

Imperialism is based on the exploitation of wage and reproduction differentials between regions and countries, races and gender, and legal and social groups. It has a strategic interest in keeping social or geographical divisions by genderising, racialising or territorialising the humanity. Migration politics aims to keep the system of borders and territories whilst in the same time exploits the wage and reproduction cost differential between countries. (IMA, 2008, p. 4)

Fernandez explicitly identified the management paradigm as a tool for control, carried out by the IOM which she considered 'nothing but fascist' (IMA, 2008, p. 8). This strong rhetoric has been consequently expanded to the GFMD fora, which the IMA wants to 'expose' as a place for the commodification of labour and a mere front-end for imperialist and neoliberal strategies. This approach is in line with the war of positions, and in order to counter the GFMD narrative, the IMA agreed on a resolution to collaborate and support the initiative of Migrante to hold the first IAMR in opposition to the GFMD in Manila. Migrante International is a global alliance of overseas Filipinos and a founding member of IMA. In the resolution, Migrante accuses the GFMD of '[hiding] under the cloak of universally-accepted concepts and principles' while actually serving the interests of 'the perpetrators of neo-liberal globalization - the World Bank and OECD' (IMA, 2008, p. 157).

While the IMA/IAMR denounce these global institutions, one can detect a notably more positive view of the UN and some of its organizations. To explicate, there are regular calls to ratify and implement central UN human rights conventions, including the International Convention on the Protection of the Rights of All Migrant Workers and members of Their Families (which has so far received only 49 ratifications, none of them from a major receiving country of migrants). And in 2016, IMA Chairperson Eni Lestari spoke before the opening plenary of the UN Summit on Migrants and Refugees:

I speak before you today with a clear message. Do not talk about us without us. We have answers and we have been voicing them. Listen and talk with us about migration, development and human rights. International conventions designed to protect us have been ratified. But they remain in a paper and not in action. You want us to remit but what we need is for you to commit - to justice, to a development that does not tear families apart and to a future that relies on the strength of its people, not to the continued export and exploitation of our labour. (Bautista, 2017, vi) ${ }^{8}$

This more open attitude towards the UN was also apparent during the first IAMR in Manila, where Jorge Bustamente, the UN Special Rapporteur on the human rights of migrants, was invited 
as a speaker. At the same event, the GFMD was denounced as a 'Global Forum on Modern Slavery' (Rother, 2009, p. 104). This reflects a perceived dichotomy between the UN as a multilateral, normative, rights-based and binding entity opposed to the GFMD as an informal tool for neoliberal exploitation. Both images are obviously somewhat simplified and symbolic but are nevertheless successfully used as representations of contrasting forms on how to address the issue of migration on a global level.

Exposing, reporting and testimony/witnessing have been the major strategies of the following IAMRs up to the seventh meeting in Berlin. The goal of the reports from various regions is to provide a picture of the situation on the ground, while testimonies are given by victims of trafficking and exploitation. These assemblies are usually followed by mobilization in the form of rallies. As mentioned above, mainstream media reporting on the GFMD process has been very limited, but the IAMR has managed to gather some attention by staged events or collaborations with other networks.

In Mexico 2010, the IAMR joined the International Tribunal of Conscience (ITC) which had collected a long list of testimonials on the abuse of migrants' rights and indigenous people. These ranged from South Africa to the Sahara, Chiapas and the Philippines, and the form of presentation included speeches and PowerPoint presentations, film documents, a skype call-in, a play and even an opera. The tribunal had started at the World Social Forum on Migration (WSFM) in Quito, Ecuador a few weeks before the Mexican GFMD and concluded in the week leading up to it in Mexico City. From there, a literal movement towards the venue of the GFMD summit in the holiday town of Puerto Vallarta followed: the IAMR led a 'Peoples' Caravan Against the Global Forum on Migration and Development' (continuing a 'Caravan of Migrant Dignity' which had begun in Honduras). Around 500 people left Mexico City, stopped overnight in Guadalajara and arrived in Puerto Vallarta in time for the government meeting. The participants consisted of IAMR delegates and the madres de los desaparecidos [mothers of the disappeared] from Honduras, the ex-braceros representing 24 states of Mexico, the indigenous peoples of Michoacan and students from Tamaulipas; the site of the horrific San Fernando massacre of 72 irregular migrant workers by drug cartels earlier that year. ${ }^{9}$ Participants declared the GFMD illegitimate and the IAMR the true voice of the migrant workers. Notwithstanding, the protesters were stopped by a police blockade some distance from the conference centre, leading to a statement by IMA Chairperson Eni Lestari: 'While they discuss how to exploit us, they silence us and they shut us out. We say to them: as long as the GFMD exists we will come back year after year to continue our fight for migrant rights'. ${ }^{10}$

Pérez-Bustillo and Hernández Mares (2016, pp. 102-103) characterize such tribunals of conscience as counter-hegemonic processes of alternative justice, arguing:

[...] both that mainstream versions of human rights discourse and practices reproduce hegemonic forms of domination and globalisation, and that the contributions of counter-hegemonic social movements are and have been always central to the reconceptualisation and expansion of existing rights through their weaving and positioning of alternative paradigms in the context of struggle. This is how new visions of human rights, and of global justice, emerge and develop, 'from below'.

By bringing together migrants and members of similarly suppressed groups such as indigenous people, they see the potential for (counter-)hegemonic articulation. This is in line with Laclau and Mouffe (2014, p. 87) who pose that the political meaning of a movement is not given from the beginning: it crucially depends upon its hegemonic articulation with other struggles and demands'.

Apparently inspired by the process, the IMA followed up with its own 'Migrants' Tribunal on the GFMD' held in parallel (if not in opposition) to the World Social Forum on Migration which took 
place in Manila in 2012. That years' GFMD was held one week before the WSFM in Mauritius. However, due to logistical and financial challenges, no parallel civil society events were organized in Mauritius. Hence, the Tribunal took place in Manila instead, held at the Diliman Campus of the University of the Philippines and presided by five judges. These included the Philippine artist-turnedactivist and former 'Miss Saigon' in a London West End production, Monique Wilson, the Indonesian Bishop Soritua Nababan and Secretary General of the International Association of Democratic Lawyers Osamu Niikura from Japan. The Tribunal heard three expert witnesses, among them the above-mentioned Dr. Irene Fernandez and Jose Jacques Medina, a Mexican activist and former undocumented Migrant to the USA, who were supported by six witnesses that provided further background information on issues such as migrant domestic workers, female migrants and seafarers.

It came as little surprise that the GFMD was found 'guilty as charged' and held responsible to:

Violations of the Complainants' (i.e. the migrants') human rights. At the pretext of protecting Complainants' human rights, the Defendants (i.e. the GFMD) prescribe Migration policies in furtherance of their neoliberal Agenda of commodification of labour and modern-day slavery as Criminal neglect / Violation of the Complainants' political, economic, social and cultural rights by the sending / receiving states. ${ }^{11}$

Further cooperation with other organizations was visible at the UN-HLD 2013 in New York, where the IAMR not only organized a flash mob but later joined as part of a much larger demonstration for immigration reform in the US with then-Mayoral candidate Bill de Blasio as one of the speakers. In Berlin, the IAMR 'Speak Out! Event' was on the one hand supported by the 'usual suspects' such as the above-mentioned ILPS, the Asia-Pacific Mission for Migrants (APMM), the CWWM (see next section) and the Philippine research institute IBON Foundation that provides regular research reports for the network. On the other hand, it also managed to build alliances with the representatives from organisations such as 'Democracy in Europe Movement 25 - Berlin', Courage, the German leftist party 'Die Linke' and a student-led 'Coalition against Trump'. However, this alliance-building is not always a smooth process. For example, at the Athens IAMR in 2008, there was an open fallout with the local organizers who accused the Filipino members of the global alliance as being too dominant. Similar sentiments were also raised by other former allies who detested an uneasy balance between the goal of widening the movement and the desire to keep it a closely controlled circle. Notably, there was no significant presence of refugee self-organizations or the German-Turkish community at the Berlin gathering - but to be fair, that was a major shortcoming of the GFMD and all its related events in Germany such as the PGA.

\section{The Churches Witnessing With Migrants}

The CWWM has its origins in the same year as the IMA/IAMR, starting with a small meeting in Manila - more precisely a luncheon with the UN Rapporteur Bustamante during his attendance of the GFMD and the IAMR in the Philippines. The CWWM has since held its meetings mostly in conjunction with the GFMD summits and the UN-HLD in New York. Its founding organizations were: the ecumenical National Council of Churches in the Philippines (NCCP); the Asia-Pacific Mission for Migrants (APMM) in Hong Kong, a research, advocacy, and movement building organization and the current secretariat of the IMA; and the aforementioned Migrante International (which was established with the assistance of APMM, highlighting the density and interconnectedness of the members of the alliance).

Over the years, CWWM has developed a 'tripartite body of equals' (Ledesma-Singson \& Lacsamana, 2017, p. 0) with the constituency consisting of 'first, migrants, refugees and displaced peoples, second, migrants and refugee-serving groups; and third, religious and faith based groups' (Bautista, 
2017, p. 3). The combination of story-telling by directly affected migrants, regional overviews and consultations bears many similarities to the IAMR and often the meetings are held one after another. However, the impact and target audience can be different. While the IMA/IAMR is often seen as a fringe/leftist group, the church organizations - although sharing similar ideologies and political convictions - can potentially reach out to larger audiences. Participation in the CWWM is moderate compared to the mass mobilizations at the IAMR in Manila and Mexico, but its members return to their communities with the goal of spreading the gospel of counter-hegemonic discourse. CWWM can thus act as multiplicator of the agenda, and its publications such as 'Turning Strangers into Friends - A Workbook on the Framework Documents of the CWWM' are explicitly conceptualized as material used for education (Bautista, 2017). In a similar vein, the publication 'The Intersections of Migration, Human Rights and Development' is presented as 'a resource book of CWWM' and dedicates a whole section to 'study guide, campaign and organizing principles' (Bautista \& Toquero, 2014). Furthermore, Reverend Mark Terwilliger from the Susquehanna Annual Conference of the United Methodist Church in the US developed 'A Leaders Guide to the CWWM Advocacy Paper', connecting bible passages to discussions about key concepts such as neoliberal globalization and unfettered movement of capital (Terwilliger, 2014, p. 311). In the same section, the aforementioned APMM shares experiences on 'organizing the migrants from the national up to international level' by building on the principles of social investigation, contact building, organizing a group and formalizing the organization (APMM, 2014, pp. 323-328). Specifically (APMM, 2014, p. 318):

Organizing is an essential element of empowering the migrants. It can even be said that establishing an organization of migrants is both an end goal and a means for empowerment for while it is a concrete proof of the empowerment of the grassroots, it will also take migrant empowerment to a wider and deeper scale.

While, as in the IMA and IAMR, there is a strong 'Filipino flavour' present in the CWWM, it seems to encompass a more diverse group of activists and organizations. One of the major supporters is the German protestant foundation Brot für die Welt (Bread for the world), a 'collective Christian voice urging our nation's decision makers to end hunger at home and abroad'. ${ }^{12}$ In Berlin, the IAMR concluded with a public panel discussion, co-hosted with Bread for the World and the protestant relief organization MISEREOR on 'People on the Move - Churches and Civil Society in International Negotiations on Migration and Development'. ${ }^{13}$ Among the discussants was a representative from the German government and Jesuit Father Michael Czerny, undersecretary to the 'Section for Refugees and Migrants' in the new Vatican department for the Promotion of Integral Human Development, thus further widening the audience of the CWWM outcomes.

\section{Conclusion}

While there has been notable progress towards a global governance of migration in the past decade, and processes such as the GFMD have become - in some regards - more inclusive to civil society, it concurrently holds true that there is a powerful 'historic bloc' of migration policies from the national to the global level. One has to keep in mind that while this article has focused on the efforts of building multilateral migration processes, the dominant actors in the policy on the ground still remain nation states and to a degree regional organizations such as the EU (which still struggles to find consensus). It is thus a justified critique that the more benign discourses of the GFMD have had rather limited effects on the actual policies towards migrants and refugees. 
The IMA and IAMR are by self-definition sources of counter-hegemonic discourses, and the analysis has shown that the networks' advocacy work fits into the strategies Gramsci suggested for a counterhegemonic war of positions. The networks have conducted comprehensive analysis - or, in their words, 'exposure' - of the underlying norms of the hegemonic discourses such as top-down management/control, narrow conceptualizations of development and circular migration schemes. The analysis has shown widespread efforts in 'actively building a counter-hegemony within an established hegemony' (Cox, 1993, p. 53), including reaching out to other marginalized groups in order to achieve 'hegemonic articulation' (Laclau \& Mouffe, 2014, p. 87). Moreover, the CWWM has acted as a multiplicator to bring the advocacy to wider and more diverse audiences besides just 'preaching to the convinced'.

While the case study fits within the theoretical framework, it raises the question on how successful the movement has been in its pursuits. In line with Cox, it has identified institutions as mechanisms to uphold hegemonic norms, but it is debatable whether the informal, non-binding GFMD is the main carrier of these norms; these are embedded more deeply into the architecture of the political and economic global system resting on institutions such as the World Bank, the WTO and regional organizations such as the EU. Granted, the IMA has also organized counter-events to some of these processes (e.g. during the WTO Ministerial Conference in Bali 2014), but one gets the impression that the GFMD is a more accessible target whose agenda is easier to convey to the migrant constituency. Hence, while the actual power of the non-binding GFMD seems to be overplayed, it provides a symbolic target for processes such as the commodification of labour. A contrary argument would run that the seemingly benign discourses during the GFMD are instrumental in disguising the unchanged hegemony and must therefore be exposed - a strategy that would also fit into countering features of these global institutions such as co-opting elites from peripheral countries and absorbing counterhegemonic ideas (Cox, 1993, p. 62).

Co-optation into the current hegemonic doctrine - trasformismo - is among the accusations of the IMA and its allies towards participation in the GFMD civil society days and inside-outside processes' such as the PGA. Changes in the GFMD discourse on issues such as human rights can be traced back to civil society interventions from the PGA and other spaces. In addition, the zero draft of the Global Compact for Migration appeared, to a significant degree, influenced by the advocacy of the networks surrounding the PGA. ${ }^{14}$ However, the question remains whether these changes in discourses will have any concrete implications on the situation on the ground. In a statement also circulated to the members of the CWWM, the APMM presented a very critical assessment of the zero draft, stating it was 'long on issues, short on ensuring action', 'Devaluing migrants as stakeholders' and problematic because of its 'sluggish follow up and review. ${ }^{15}$

The question regarding changes on the ground, however, could also be directed towards the IMA strategy. Specifically, while the IMA may have been able to chip some parts off the 'historic bloc' on migration management through its counter-hegemonic discourse, there is no clear strategy towards institutional change. The statements that can be read in this way seem to support an existing institution; a somewhat idealized image of the United Nations (and a more specific commitment to its human rights conventions). This was underlined by the IMA response to the development of the Global Compact for Migration. Namely, when in December 2017, the US government declared to withdraw from the process, the IMA was swift to condemn this move as 'a callous disregard of the need for the international community to address pressing concerns of the millions of displaced peoples' and saw it as an indicator that 'challenges thrown to the GCM process by migrants and advocates to make the said compact address human rights, labor issues, gender concerns, and the root causes of migration' were apparently not consistent with Trump's immigration policy directions (statement on IMA Email list 4th of December 2017). 
The IMA and its partners have been clearer with regard to their formulations of policy goals and underlying norms. Therefore, it could be argued that in their war of position, they want to instigate change by first establishing an alternative discourse. This change, however, remains a long-term objective. Thus, in the meantime, migrant activists such as Eni Lestari might very likely remain very angry birds of passage indeed as Lestari (2014, p. 142) usefully concludes:

In the era of neoliberal globalization, should management of migration be the focus? If yes, then we are concerned and outraged! By managing migration, we are reduced to a commodity, turned into moderndays slaves filling the needs of developed countries for cheap and docile labour, and generating income and pumping the economy of sending countries with remittances and the onerous fees regularly extorted from us.

\section{Notes}

1. https://gfmd-blog.com.

2. Tweet by @IOMatUN 7:38 PM - 16 Jun 2017.

3. It should be noted, though, that the division is not as clear-cut as some members of the 'outsiders by choice' networks have been accredited participants in processes such as the GFMD or even spoke in front of the United Nations. On the other hand, for some, the outsider role might not be a result of choice but of necessity as they have no option to fulfil the accreditation criteria, gather the necessary resources etc.

4. https://wearemigrants.net/about/.

5. https://wearemigrants.net/about-the-iamr/.

6. http://nccphilippines.org/cwwm/?page_id=14.

7. As stated in the constitution: 'The IMA is a broad anti-imperialist alliance that will uphold and promote the rights and welfare of all migrant workers, immigrants and refugees' (IMA, 2008, p. 131).

8. See also http://statements.unmeetings.org/media2/7660310/ima.pdf.

9. https://gfmd2010.wordpress.com/2010/11/16/the-protest-caravan-is-in-town-but-where-is-it/.

10. https://iamr3.wordpress.com/2010/11/16/migrants-from-around-the-world-blocked-fromapproaching-the-site-of-gfmd/.

11. https:/gfmd2010.wordpress.com/2012/11/29/international-migrants-tribunal-miss-saigon-vs-the$\mathrm{gfmd} /$.

12. http://www.bread.org/about.

13. Disclosure: Bread for the World (jointly with the Friedrich Ebert Foundation, FES) also commissioned a background paper on migration, development, the GFMD and the Global Compact, primarily targeted at German migrant self and support organisations, from the author of this paper.

14. https://gfmd2010.wordpress.com/2018/02/09/on-a-rights-path-my-first-thoughts-on-the-zero-draft-ofthe-global-compact-formigration/.

15. https://www.facebook.com/permalink.php?story_fbid=1828229143874805\&id=140253342672402.

\section{Disclosure statement}

No potential conflict of interest was reported by the author. 


\section{ORCID}

Stefan Rother (D) http://orcid.org/0000-0001-8520-3365

\section{References}

Ashutosh, I., \& Mountz, A. (2011). Migration management for the benefit of whom? Interrogating the work of the international organization for migration. Citizenship Studies, 15(1), 21-38. Retrieved from https://doi. org/10.1080/13621025.2011.534914

Asia-Pacific Mission for Migrants. (2014). Empowerment of the grassroots through organizing. In L. C. Bautista, \& M. S. H. Toquero (Eds.), The intersections of migration, human rights \& development justice: A resource book of churches witnessing With migrants (pp. 318-330). Quezon City: National Council of Churches in the Philippines \& General Board of Church and Society of the United Methodist Church.

Bautista, L. C. (Ed.). (2017). Turning strangers into friends: Hospitality, mercy, justice. A Workbook on the Framework Documents of The Churches Witnessing With Migrants (CWWM). Manila: National Council of Churches in the Philippines.

Bautista, L. C., \& Toquero, M. S. H. (Eds.). (2014). The intersections of migration, human rights \& development justice: A resource book of churches witnessing with migrants. Quezon City: National Council of Churches in the Philippines \& General Board of Church and Society of the United Methodist Church.

Betts, A. (2011a). Global migration governance. Oxford: Oxford University Press.

Betts, A. (2011b). Introduction: Global migration governance. In A. Betts (Ed.), Global migration governance (pp. 1-33). Oxford: Oxford University Press.

Brickner, R. K. (Ed.). (2013). Migration, globalization, and the state. Basingstoke: Palgrave Macmillan.

Buttigieg, J. A. (1995). Gramsci on civil society. Boundary, 22(2), 1-32.

Cholewinski, R., \& Tayah, M.-J. L. (2015). Promoting decent work for migrant workers. Geneva: ILO. Retrieved from http://www.ilo.org/wcmsp5/groups/public/---ed_protect/---protrav/---migrant/documents/publication/ wcms_344703.pdf

Cox, R. W. (1981). Social forces, states and world orders: Beyond international relations theory. MillenniumJournal of International Studies, 10(2), 126-155.

Cox, R. W. (1993). Gramsci, hegemony and international relations: An essay in method. In S. Gill (Ed.), Cambridge studies in international relations: Vol. 26. Gramsci, historical materialism and international relations (pp. 49-66). Cambridge: Cambridge University Press.

Düvell, F. (2011). Irregular migration. In A. Betts (Ed.), Global migration governance (pp. 78-108). Oxford: Oxford University Press.

Evans, T., \& Ayers, J. (2006). In the service of power: The global political economy of citizenship and human rights. Citizenship Studies, 10(3): 289-308.

Fine, J., Milkman, R., Iskander, N., \& Waldinger, R. (2016). Celebrating the enduring contribution of birds of passage: Migrant labor and industrial societies. ILR Review, 69(3), 774-782. Retrieved from https://doi.org/ $10.1177 / 0019793916636094$

Geiger, M., \& Pécoud, A. (2010). The politics of international migration management. London: Palgrave.

Gill, S. (1990). American hegemony and the trilateral commission. Cambridge: Cambridge University Press.

Gill, S. R., \& Law, D. (1989). Global hegemony and the structural power of capital. International Studies Quarterly, 33(4), 475-499.

Hsia, H.-C. (2009). The making of a transnational grassroots migrant movement in Hong Kong: A case study of Hong Kong's asian migrants' coordinating body. Critical Asian Studies, 41(1), 113-141.

International Migrants Alliance. (2008 June 15-16). Founding assembly documents. Hong Kong: IMA.

Kalm, S. (2008). Governing global migration. Lund: Lund University.

Kapur, D. (2003). Remittances: The new development mantra? (G-24 Discussion Paper Series No. 29). Washington, DC: The World Bank. 
Koslowski, R.2011. Global mobility regimes. New York, NY: Palgrave Macmillan.

Kunz, R. (2013). Governing international migration through partnership. Third World Quarterly, 34(7), 12271246. Retrieved from https://doi.org/10.1080/01436597.2013.825089

Laclau, E., \& Mouffe, C. (2014). Hegemony and socialist strategy: Towards a radical democratic politics (2nd ed.). Radical thinkers. London: Verso.

Ledesma-Singson, M., \& Lacsamana, M. (2017). 8th international consultation of the churches witnessing with migrants (CWWM). Berlin: CWWM.

Lestari, E. (2014). Your neighbour is inviting You for partnership and solidarity. In L. C. Bautista \& M. S. H. Toquero (Eds.), The intersections of migration, human rights \& development justice: A resource book of churches witnessing with migrants (pp. 142-146). Quezon City: National Council of Churches in the Philippines \& General Board of Church and Society of the United Methodist Church.

Morokvasic, M. (1984). Birds of passage are also women ... International Migration Review, 18(4), 886-907.

Newland, K., Agunias, D. R., \& Terrazas, A. (2008). Learning by doing: Experiences of circular migration (Insight. Program on Migrants, Migration, and Development).

Onuki, H. (2007). Migration workers as political subjects: Globalization-as-practices, everyday spaces, and global labour migrations. Refuge: Canada's Periodical on Refugees, 24(2), 125-134.

Pécoud, A. (2015). Depoliticising migration: Global governance and international migration narratives. Basingstoke: Palgrave Pivot.

Pérez-Bustillo, C., \& Hernández Mares, K. V. (2016). Human rights, hegemony, and utopia in Latin America: Poverty, forced migration, and resistance in Mexico and Colombia. Studies in critical social sciences: Volume 87. Leiden: BRILL.

Piore, M. J. (1979). Birds of passage: Migrant labor and industrial societies. New York, NY: Cambridge University Press.

Piper, N., \& Rother, S. (2012). Let's argue about migration: Advancing a right(s) discourse via communicative opportunities. Third World Quarterly, 33(9), 1735-1750. Retrieved from https://doi.org/10.1080/01436597. 2012.721271

Piper, N., \& Rother, S. (2014). More than remittances: Resisting the dominant discourse and policy prescriptions of the global 'migration-development-mantra'. Journal für Entwicklungspolitik (JEP), 30(1), 44-67.

Rother, S. (2009). "Inside-Outside" or "outsiders by choice"? civil society strategies towards the 2nd global forum on migration and development (GFMD) in Manila. ASIEN - The German Journal on Contemporary Asia, (111), 95-107. Retrieved from http://www.asienkunde.de/content/zeitschrift_asien/ archiv/pdf/111_rother.pdf

Rother, S. (2012). Standing in the shadow of civil society? The 4th global forum on migration and development (GFMD) in Mexico. International Migration, 50(1), 179-188.

Rother, S. (2013). A tale of Two tactics: Civil society and competing visions of global migration governance from below. In M. Geiger, \& A. Pécoud (Eds.), Disciplining the transnational mobility of people (pp. 4162). Basingstoke: Palgrave Macmillan.

Rother, S. (2017). Indonesian migrant domestic workers in transnational political spaces: Agency, gender roles and social class formation. Journal of Ethnic and Migration Studies, 43(6), 956-973. Retrieved from https:// doi.org/10.1080/1369183X.2016.1274567

Rother, S. (2018). The global forum on migration and development (GFMD) as a venue of state socialization: A stepping stone for multi-level migration governance? Journal of Ethnic and Migration Studies, 44. Retrieved from https://doi.org/10.1080/1369183X.2018.1441605

Schierup, C.-U., Ålund, A., \& Likić-Brborić, B. (2015). Migration, precarization and the democratic deficit in global governance. International Migration, 53(3), 50-63. Retrieved from https://doi.org/10.1111/imig. 12171

Schierup, C.-U., Munck, R., Likić-Brborić, B., \& Neergaard, A. (Eds.). (2015). Migration, precarity, and global governance: Challenges and opportunities for labour (1st ed.). Oxford: Oxford University Press.

Soguk, N. (1999). States and strangers: Refugees and displacements of statecraft. Borderlines: v. 11. Minneapolis: University of Minnesota Press.

Terwilliger, M. (2014). A leaders guide to the CWWM advocacy paper. In L. C. Bautista \& M. S. H. Toquero (Eds.), The intersections of migration, human rights \& development justice: A resource book of churches witnessing With migrants (pp. 305-317). Quezon City: National Council of Churches in the Philippines \& General Board of Church and Society of the United Methodist Church. 
Wallerstein, I. M. (2004). World-Systems analysis: An introduction. Durham, NC: Duke University Press.

Wee, K., Vanyoro, K. P., \& Jinnah, Z. (2018). Repoliticizing international migration narratives?: Critical reflections on the civil society days of the global forum on migration and development. Globalizations. doi:10. 1080/14747731.2018.1446600

Wickramasekara, P. (2011). Circular migration: A triple win or a dead end (GURN Discussion Paper No. 15). Geneva: ILO. 


\title{
'Getting to the root causes of migration' in West Africa - whose history, framing and agency counts?
}

\author{
Nora McKeon
}

\begin{abstract}
Today's 'irregular migration' from Sub-Saharan Africa has its roots in decades of policies which have impoverished rural economies and dispossessed smallscale producers to make room for export-oriented monocultures. Under pressure from opportunistic xenophobic political configurations the EU is reacting by seeking to block the unwanted flow of African migrants in their home countries through measures denounced by European civil society organizations. Its long-term recipe for 'addressing the root causes of migration' involves using EU cooperation funds to leverage resources from private investors 'looking for new investment opportunities in emerging markets', thereby promoting the same model of agricultural production and global value chains that has sparked today's migration waves. An absent voice in the debate is that of the rural organizations in the territories from which the migrants originate. This paper seeks to reframe the issues from the viewpoint of these social constituencies, to recuperate their popular history of the evolutions that have transformed a portion of rural mobility into Europe-bound irregular migration, to map relevant contemporary rural transformations and the complexities of relations they engender, and to highlight initiatives underway today to build options of dignified and remunerative rural livelihoods for young people. Setting the West AfricaEurope nexus in the context of global processes of migration governance, this paper explores the opportunities for counter-hegemonic strategizing that EU internal policy contradictions open up and suggests how convergences might be promoted among actors and spaces that are currently inadequately connected with a view to defending both the right to migrate and the right to choose to stay at home.
\end{abstract}

The towns and citizens that constitute the vast majority of the troops that are candidates for emigration come from continents that have been violated, humiliated, plundered by force and now by international agreements. The resources of these states continue to be diverted towards banks and financial institutions in countries that protest against illegal immigration. (Cissokho, 2018)

\section{Introduction}

The 'migration crisis' that is currently holding sway over European politics and relations with Africa introduces interesting variations on the theme of migration, governance and civil society. It 
highlights the importance of the regional level in constructing the narratives and governance approaches that dominate international initiatives like the Global Forum on Migration and Development. It illustrates the difficulties of incorporating radical reflection on the structural root causes of migration into civil society advocacy in a situation in which the NGOs who have most voice are focused on denouncing extreme violations of migrants' human rights and where a space bringing them into dialogue with other concerned actors on both sides of the Mediterranean is not in place. At the same time, it suggests that the EU's internal contradictions of seeking to manage migration in function of European enterprises' hunger for profits while also addressing the populist xenophobic backlashes induced by globalization may open opportunities for counter-hegemonic strategizing that can be translated into concrete terms close to home more easily than in the rarified atmosphere of global negotiations.

Mobility is a human right, when it is a matter of choice. But where to draw the line between voluntary and involuntary? 'Involuntary' refugees of conflict and political persecution are accepted into the European fortress on human rights grounds whereas 'economic migrants' are expelled, presumably because they have 'freely chosen' to be mobile (Delgado Wise, SI, p. 6). Here we encounter the distinction between political and economic and social rights that has dogged the international human rights framework from the outset, as well as the relative 'invisibility' of the cumulative effects of longterm structural violence as compared with headlines-grabbing catastrophes. Much of today's 'irregular migration' from Sub-Saharan Africa (SSA) to Europe originates in West Africa. It is of the 'economic' variety, rooted in decades of policies which have impoverished rural economies and dispossessed small-scale producers to make room for exported-oriented monocultures. Under pressure from nationalist populist and xenophobic political configurations the EU is reacting by seeking to block the flow of unwanted African migrants in their countries of origin. Its long-term recipe for 'addressing the root causes of migration' through development follows the dominant doctrine of private sector-led modernization. It consists in using EU cooperation funds to 'crowd in' European agribusinesses 'looking for new investment opportunities in emerging markets' (EC, 2017), thereby promoting the very model of agricultural production and global value chains that has fuelled today's migration waves.

European civil society advocacy tends to concentrate on defending the value of mobility and the human rights of African migrants. ${ }^{1}$ This is a critical platform. However, it is not adequate to address the long-term structural causes of the agrarian malaise that underlies current forms of migration from SSA nor to reveal the discursive contortions that have veiled over a century of exploitation of African rural territories. An absent voice in the debate is that of the communities from which the migrants originate and the rural organizations that are working to ensure that young people have the option of dignified and remunerative livelihoods at home. This paper seeks to reframe the issues from the viewpoint of these social constituencies, to recuperate their popular history of the evolutions that have transformed a portion of rural mobility into Europe-bound involuntary migration, to illustrate relevant contemporary rural transformations, and to highlight initiatives underway today to build alternatives for rural young people. It will also discuss the policy responses of the European Union, which seek to further what authorities interpret as 'European interests'. The paper will explore some of the contradictions and the opportunities that the West African-Europe nexus incorporates and suggest how convergences might be promoted among actors and spaces that are currently inadequately connected with a view to defending both the right to migrate and the right to choose to stay at home. 


\section{The evolution of migration and its drivers in West Africa ${ }^{2}$}

Mobility has always been an inherent component of life in West Africa. Before the colonial period population movements were largely associated with internecine warfare, natural disasters and the search for cultivable land or colonization (Adepoju, 1998). In the Sahel mobility is accentuated both by the important presence of pastoralist communities and by the long dry season, which has stimulated the consolidation of common patterns of seasonal travel over hundreds of years.

The destructive impacts of colonialization on endogenous societies have been fully and dramatically described both in academic studies (Watts, 1983) and in literary portrayals (Achebe, 1959). Its effects on all aspects of West African life, including migratory patterns, cannot be overestimated. Ethnic groups were divided and pastoralist seasonal movements of livestock disrupted by imposed frontiers. After the abolition of slavery the colonial administration introduced various forms of conscripted labour, often involving imposed mobility, to meet objectives such as providing manpower for cash crop plantations or constructing the railways and roads that evacuated products to ports. As always with the various forms of colonial exploitation, this practice was justified by the allegedly indolent character of the colonized and the civilizing mission of the colonizers. "The Negro does not like work and is totally unaccustomed to the idea of saving; he does not realize that idleness keeps him in a state of absolute economic inferiority. It is therefore necessary to use the institutions by which he is ruled to improve his circumstances' (1901 report to the French Minister of Commerce, quoted in Fall, 2002).

John Illife's history of The African Poor (1987) distinguishes between the main causes of poverty in pre-colonial Africa and the new entries in the twentieth century. The advent of cash cropping disrupted both the ecological and the socio-economic equilibria of West Africa. Monoculture consumed soil fertility and provoked erosion of the fields, previously protected by traditional practices like inter-cropping and minimum tillage which European agronomists condemned as messy, lazy and primitive. The pressure of cash cropping, coupled with population increase, provoked a curtailing of fallow periods and subverted the complementary of cultivation and livestock. Peasants were induced or coerced to grow cash crops by the introduction of taxation and monetization of the economy. The monetary demand exercised on peasant producers in the form of taxes and the prices charged for manufactured goods and staples outweighed the monetary value of their agricultural produce $^{3}$, and producer prices were subject to unpredictable fluctuations. Precariousness had previously been largely a function of natural hazards which farmers could foresee to a good degree and against which they had developed an arsenal of defence, including mobility measures. Now it depended on the interests of the colonial powers and on market mechanisms which totally escaped their ability to strategize.

The unequal exchange and the advance credit system practiced by merchants and money-lenders provoked a no-exit spiral of debt in rural areas, prevented peasants from accumulating capital to invest in increasing productivity and stressed the extended family unit. The family head found it increasingly difficult to fulfil his responsibilities towards the members of his entourage and the depleted collective grain reserves no longer sufficed to meet the collective needs. The position of women deteriorated. Their work load was intensified while the cash revenues passed into the hands of the men, introducing a dualism between 'modern' cash and 'invisible' domestic subsistence sectors that has persisted up to today. Colonialism and the cash nexus also generated new socio-economic inequalities which were no longer subject to control by stable norms. In a very pervasive way, the colonial experience discredited African people's knowledge, skill, culture and values. 
Little changed for rural people with the attainment of political independence in the early ' 60 s. State interventionist policies in the Sahel did succeed in disseminating the use of animal traction, improved seed and fertilizers, resulting in gains in production and productivity. As elsewhere in Sub-Saharan Africa, however, the underlying goal was the extraction of financial surplus through the pricing policy of the state marketing boards. Fear of urban unrest led governments to ensure cheap food in urban areas by depressing farmgate prices and importing commodities (Bates, 1981), putting a spin on the vicious circle whereby African producers have lost their natural markets to artificially cheap surplus production from abroad.

The state-guided model that was applied in the first decades of independence was rhetorically inspired by a vision of prosperous agriculture that would 'raise the productivity of the African peasant, liberating him from the bondage that is so out of place in the twentieth century. ${ }^{4}$ Nonetheless, the model of development that it adopted marginalized peasants. Faithful to modernization theory, development was conceived as a continuum from less to more, requiring external injections of modern capital and technology and negating the value of local knowledge and innovative capacities of rural people. Rural producers were organized into cooperatives to promote the production and marketing of export crops. When they succeeded in escaping from the logic of the State-promoted programmes and reinserting themselves in a diversified production mode rooted in the moral economy, development professionals from both capitalist and socialist schools judged such 'traditional' behaviour on the part of an 'uncaptured peasantry' to be an obstacle to development (Hydén, 1980). The former colonial powers, morphed into 'development partners', were supportive of this approach. Senegal's major donors in 1961 - France and the European Economic Community - declined to consider package support for the overall development plan that the newly independent country presented to them. The programmes that did receive funding were those aimed at promoting the production and marketing of single export crops - rice, groundnuts and cotton - through the establishment of specialized parastatal regional development structures that disregarded the polyvalent nature of peasant agriculture, the socioeconomic logic of the extended family unit, the knowledge and skills of the farmers, and the impact of monoculture on the environment. As a founding organization of the Senegalese peasant movement put it in retrospect, 'All told, the peasant didn't even need to think anymore. The State took care of everything, convinced as it was that only a centralized state planning system could ensure the rapid development of the country' (FONGS, 1991).

It took mass deaths due to drought and famine in the mid 1970s to start to bring home the fact that African rural areas were dramatically impoverished and that, as Robert Bates demonstrated in his classic study of markets and states, this had a lot to do with poor policies (Bates, 1981). African Heads of State meeting in Lagos in 1981 admitted that neglect of rural areas and producers was the primary cause of food shortages. 'Member States have not usually accorded the necessary priority to agriculture, both in the allocation of resources and in giving sufficient attention to policies for the promotion of productivity and improvement of rural life.' (OAU, 1981). Yet a reversal of the tide of policies in a pro-rural, pro-agriculture direction did not follow, although some governments did experiment with measures to support production and marketing of food crops with encouraging results. Perhaps because, as Bates also pointed out, poor policies had a lot to do with politics (Bates, 1981). Sahelian peasant farmers had begun to wake up to these realities, but they were powerless then to do much about it.

If it weren't for the peasant, the civil servant wouldn't eat. But our problem is that we don't have anyone to defend us. If civil servants have complaints they appeal to their union, but us - who is to defend us? They buy our produce at the conditions they fix, and we have nothing to say about it. ${ }^{5}$ 
Whatever changes in agricultural policies the political will mustered at Lagos might have fostered were overtaken by the structural adjustment prescriptions which the International Monetary Fund and the World Bank obliged debt-ridden West African governments ${ }^{6}$ to apply from the early 1980 s on in return for the credits they needed to keep their heads above water. These SAPs focused on 'balancing the books' through privatization, opening up of markets (exacerbated by the advent of the WTO in 1995), and State withdrawal from its intervention in the economy through measures such as subsidies, extension services and state marketing boards (Tobias, SI, p. 3). Little or no consideration was given to the impacts such policies would have on rural livelihoods. It was assumed that the private sector and peasant organizations themselves would step in to fill the void left by state withdrawal, but no accompanying measures were foreseen and peasant organizations were not invited to sit at the negotiation table.

The further disruption of rural livelihoods and the basic family unit, from independence on, could only be expected to increase recourse to migration as a coping strategy. The term 'urban drift' entered the development establishment's vocabulary in the '70s, but attention to the phenomenon was ambivalent since modernization theory equated urbanization with progress. Inter-country mobility was affected by the regulations governing immigration introduced by the newly established nation-states, but the period of economic boom for cash crops induced the countries concerned ${ }^{7}$ to encourage migration from elsewhere in the region. This dynamic was disrupted by the economic, social and political crises of the '90s in key destination countries, leading to phenomena such as the development of new migration circuits, the emergence of networks of illicit traffic of migrants, and an augmentation of clandestine departures towards Europe (Ba, 2007 Robin, 2007), the first signs of today's 'migration crisis'.

\section{Birth and evolution of the West African peasant movement}

How did rural people themselves react to the disruption of their lives and the exploitation of their labour? Already in the late ' 60 s and early ' 70 s initiatives began to develop on the margins of the statecontrolled export crop-oriented rural cooperatives, particularly in those countries where the political environment was more permissive than in the military dictatorships in which the region abounded. In Burkina Faso in 1967, witnessing the disconnect between government-promoted cooperatives and rural people, a highly motivated teacher ${ }^{8}$ facilitated the transformation of a traditional Mossi youth group, the Komi-Naam ('power of the young'), into an autonomous association aimed at building economic and social security and solidarity in the communities concerned. In Senegal autonomous peasant associations began to spring up in various regions of the country in the early '70s, as rural people broke with a habit of fatality to seek solutions to problems with which the all-provident state was impotent or unwilling to deal. The membership was dominantly women and young men, the 'powerless' both in the traditional structures and in the 'modern' cash economy, and the associations had to negotiate their space with the village elders, on the margins of the main agricultural activities of the family units. By 1974 the associations were exchanging visits and meeting among themselves. In 1976, at the initiative of a Senegalese NGO whose President ${ }^{9}$ had been an official in the extension service, 12 associations formed a national federation. It obtained legal status in 1978 as the Fédération des ONG Sénégalaises (FONGS), a title imposed by the government to distinguish them from the official co-operatives.

The combination of the onslaught of the SAPs and another severe drought in the mid-1980s stimulated a further development of the autonomous associations. An insight into this process is provided by an initiative undertaken by African CSOs in partnership with European NGOs and 
the UN Food and Agriculture Organization (FAO) in 1986-8. The Image of Africa project documented the food security crisis seen from the point of view of the communities directly affected through case studies undertaken by national CSOs in six drought-affected countries. ${ }^{10}$ The synthesis of the national studies reported that, despite the wide diversity of situations examined, rural people generally reacted in a positive and creative way to the crisis, calling on a variety of solidarity mechanisms, undertaking new activities, and building up their organizations. The crisis seemed to have functioned as a stimulus to peasant associations to reflect on the structural causes of food shortages and to elaborate alternative development strategies more adapted to their situation and environment than the models proposed by national and foreign 'developers'. Yet, the reports demonstrated, neither national governments nor foreign donors seemed able to recognize and reward these self-reliant efforts. 'In its present modalities development assistance often tends to block social transformations necessary to development, rather than providing support for peasant strategies and movements ...' (McKeon, 1988 p. 19).

State retrenchment stimulated the Senegalese FONGS, one of the organizations included in the study, to intensify and broaden its activities from the mid-80s on. Among the key challenges identified at the FONGS' General Assembly in 1991 was that of gaining access to the resources of national rural development programmes of which peasants were the intended beneficiaries, a strategic indication since the Agricultural Structural Adjustment Program (ASAP) was then in the offing (FONGS, 1991). The FONGS had expanded to include 24 regionally-based associations throughout the country totalling over 2000 village groups with an active membership of about 400,000, but the Government rejected its requests to take part in the ASAP discussions on the grounds that it was not the only national federation representing rural people. The movement's response was to organize a national forum in early 1993, dramatically entitled 'What Future for Senegal's Peasants?' For the first time rural people, the majority of the population, presented the government with their assessment of the impacts of structural adjustment and their proposals for the future. The Forum laid the basis for the establishment of an inclusive National Committee for Rural Peoples' Dialogue (CNCR) which the government was obliged to accept as an interlocutor.

Over the past $2 \frac{1}{2}$ decades the CNCR has been engaged in a process of building its strength and legitimacy, its alliances, and its capacity for negotiation and confrontation with the State. The first step was a vigorous campaign to re-appropriate peasant farmers' identity, pride, and sense of responsibility, deflated by decades of the treatment evoked above. The second was to build a common identity and a platform based on family farming, the basic, integrated unit of Senegalese agriculture and society, overcoming the fracture between cash crops dominated by the male head of family and the activities of FONGS association members.

It was evident from the outset that organizing the peasant movement at national level would not suffice in an environment in which decision-making levels were rapidly escalating. The year 2000 saw the creation of the Network of West African Peasant and Agricultural Producers' Organizations (ROPPA), which now groups 13 national platforms and some 80 million farmers. ROPPA represents West African family farmers vis-à-vis the regional authorities and in continental and global forums. Its platform calls for protecting West African producers from unfair competition from abroad; directing public policies and investment toward support for sustainable family-based agriculture; enacting land reform and seed laws that protect peasant producers; investing in rural social services and infrastructure; building domestic and regional food systems in which small-scale producers and rural territories retain value added through processing and marketing; ensuring peoples' participation in determining policies. Since 2000 ROPPA has made important gains in accrediting the 
peasant movement as a political actor and influencing national and regional policies (Gyapong, 2017 McKeon, Watts, \& Wolford, 2004).

\section{The current 'migration crisis': European framing, interests and solutions}

Intra-African mobility represents $70 \%$ of West African mobility, although there has been an increase in migration directed towards Europe over the past few years (https://www.iom.int/west-andcentral-africa). Yet the European perception of West African migration is appropriately expressed in the title of a recent article by West Africa peasant leader Mamadou Cissokho: 'To arms, citizens! We're being invaded ....' As a recent study notes,

sensationalist media reportage and popular discourses give rise to an image of an 'exodus' of desperate Africans fleeing poverty at home in search of the European 'El Dorado'. Millions of Africans are believed to be waiting to cross to Europe at the first opportunity. (Flahaux \& De Haas, 2016)

This distorted image of reality has become an explosive issue in a political climate in which nationalist and xenophobic populism is on the rise.

Unable to impose a collective and equitable intra-European management of the migration question, the European Union's initial response has been to seek to block the unwanted travelers through restrictive measures that have been strongly criticized by European civil society advocates. In the view of the coordination of European development NGOs, CONCORD, the European Trust Fund for Africa set in place following the 2015 Valletta Summit on migration

diverts Official Development Assistance (ODA) ${ }^{11}$ to reach objectives and finance actions that are no longer linked to the EU's development goals but rather to the EU's internal political goal of stemming migration flows. In addition, serious questions remain as to ... what the consequences of the EU new approach are for development, human rights, governance and security in partner countries. (CONCORD, 2017a, p. 3)

The EU's long-term goal is expressed in terms of addressing the 'root causes' of irregular migration. This concept, widely adopted in the development world literature (see FAO, 2016), has been critiqued on several grounds. It is essentially apolitical in its analysis. It facilitates states' desire to derogate their responsibilities for accepting migrants in their territories. It is also rooted in a simplistic understanding of the complex economic factors related to migration and an inadequate understanding of migration processes (Gent, 2002) based, among other principles, on 'the myth of the immobile peasant' (Skeldon, 2014). The developmentalist assumption that migration is a win-win proposition and that migrants are rational economic individuals has been discredited both by World System theory and the dependency school and from a post-colonial perspective (Sjoberg, 2008). Students of migration have questioned the contradiction between Europe's intention to restrict illegal immigration and the demand within Europe for cheap labour, as well as the 'root cause' approach's assumption that migration will diminish with economic development (De Haas, 2007).

The EU's key long-term instrument, the External Investment Plan (EIP), was instituted in the context of the Migration Partnership Framework adopted in June 2016. It is described as an instrument to 'promote inclusive growth, job creation and sustainable development and so tackle some of the root causes of irregular migration' (European Commission, 2017). With a contribution of $€ 4.1$ billion from the European Commission's aid budget, the External Investment Plan is expected to leverage more than $€ 44$ billion of investments from European private sector investors by 2020 . 
The EIP provides 'guarantees' to promote investments in countries where they are 'currently difficult' and to facilitate investments by private actors 'that would otherwise invest less or not at all'. At the same time, the EIP 'policy dialogue' pillar will 'help to improve the business environment in partner countries by supporting reforms and economic governance' (1981). These hypes are hardly encouraging, since the kind of initiative in which private actors who need incitement are likely to invest are typically not ones that benefit small-scale producers and rural communities. As for 'improved business environment', past experience, as in the case of the New Alliance for Food Security and Nutrition, demonstrates that it is all about tax breaks for corporations and opening up land and input markets. These and other aspects of the EIP, including its opaque governance system, have been critiqued in detail by European CSOs (Counterbalance, 2017). The EIP's Investment Window for 'Sustainable Agriculture, Rural Entrepreneurs and Agribusiness' reiterates the dominant narrative regarding the need to invest capital and technology in creating job opportunities for young entrepreneurs in global value chains, ignoring the accumulating evidence that these supply chain models lock out all but the best resourced (male) producers in the most productive areas of SSA countries. Investment in agriculture, the EIP document states, will respond to the lack of financing mechanisms adapted to smallholders in particular (European Commission, 2018). However, no effort was made to consult them in designing the Window, and their potential access to the funds would have to be mediated by financial institutions like the European Investment Bank and the African Development Bank which are notoriously unequipped to work with small-scale producers.

The trend towards promoting a 'strengthened role for the private sector' in agricultural development and food security is not limited to the EIP, but pervades the full range of relevant EU policy orientations. A recent CONCORD publication highlights the ambiguity and policy incoherence of this tendency.

The category of 'private sector' should be understood as a continuum of various actors, ranging from small-scale producers operating on family farms through micro, small and medium enterprises (MSME) up to large transnational corporations. These different actors have significantly different interests and objectives. The diversity and the imbalances in power are not adequately recognised when governments and donors facilitate private sector engagement in agriculture, for example through publicprivate partnerships and private finance blending. Small-scale producers are often considered as beneficiaries or targets of agriculture development policy and programmes rather than as agents of change in their own right. It is important to be clear about what approaches are actually supportive of them, and to listen carefully to what they have to say about their own priorities. (CONCORD, 2017b, p. 11)

\section{And through the eyes of West African rural communities?}

Instead, there is a remarkable failure to draw on the reflections of West African rural peoples' movements and communities in the literature analyzing the drivers of migrations and proposing policy responses, despite the existence of rich repositories of individual and collective deliberations and the steadily increasing visibility and advocacy capacity of organizations like ROPPA and the CNCR. When one does consult these sources the image that emerges, not surprisingly, is quite different from the 'made in Europe' versions concocted by the media or constructed by EU authorities. To begin with, the framing of the current situation as a migration 'crisis' is questioned. Rural people do not consider it to be an unexpected emergency, but rather the result of an evolution that they had seen unfolding over the long term. The use of the term 'crisis' obviously affects the responses proposed, privileging short-term solutions to conjunctural situations over long-term responses to structural problems. 
A series of reflections undertaken by Senegalese associations during the mid-80s drought testify to how rural people framed and considered the challenges they were experiencing already three decades ago (ENDA, 1985). To begin with, the question posed by the French NGO which funded the exercise - 'what development would you like to see in your village?' - was recast by the associations to be preceded by the questions 'what changes have taken place in our lives and our environment' and 'how did our grand-parents live?' The villagers preferred to build strategies for the future on a solid basis of understanding where they were and how they had gotten there. This desire to maintain control of a project for one's own society has been expressed by peasant leader Mamadou Cissokho in the following terms:

Africa has resisted considerable shocks: the slave trade, colonial exploitation, natural calamities. A hundred times over our societies could have disappeared. What is the secret of this resistance? Our values. If we want to build a sustainable development we have to start with what we are, we peasants as human beings living in our territories, sharing moral, religious, cultural and social values that have allowed us to address the difficulties that life presents. (Cissokho, 2009, p. 250)

West African rural communities - which have continued to feed their countries despite almost total lack of support from national and global policies and programmes - continuously re-embed the realities they confront in their social and territorial contexts. Developmental thinking and the attainment of corporate interests, on the contrary, require an opposed operation of disembodiment and homogenization. What the development world referred to with pudor as an incorporeal tendency towards 'urban drift' was registered in the mid-80s as a 'mutilation of the villages' by those directly concerned (ENDA, 1985). That some of the causes were political was clearly recognized. 'Problems have multiplied: the government has withdrawn its support, yields are dropping and this leads to an increase in the cultivated surfaces. Young people no longer have access to land' (ENDA, 1985). But there were also issues that the villages and associations themselves could try to address. The strategic thinking exercise that the mid-' 80 s drought stimulated led in the direction of developing activities that could provide work during the off-season.

Many of the young people who go to the cities are unemployed and that cuts them off from their parents and the territory. It's the young people who are the future of the village. We need to develop activities like vegetable production that they can undertake. (ENDA, 1985, p. 120)

Other areas of innovation included experimenting with technics like compost and anti-salt dams, cisterns to trap rain water, animal traction, saving and credit schemes, literacy classes and rural radio. Beyond single measures, communities reflected collectively on changes to make within the villages, men and women working together, and elders and young people.

Before the elders told young people what they had to do. Now, there is collaboration between the elders and the young people. When we started our groups the elders didn't agree. Now that they see our results they approve of them. (ENDA, 1985, p. 26)

Over the following years the pressure on the basic unit of West African agricultural production continued unabated. A new phenomenon, the security-threatening 'youth crisis', was being discovered and framed - as always - outside of its social context. In the words of Cissokho:

We attach a good deal of importance to the family farms, since it's at the level of peasant families that the small decisions are taken, year after year, which - when added up - allow us to discretely adapt and transform our agricultures. Instead, when the State turns specifically to young people urging them to cultivate cash crops it doesn't seem to realize that the young people live and are nourished in the family. We have come close to an implosion of the family without having a substitute on hand. (Cissokho, 2009, p. 203) 
Most official diagnostics of the 'youth crisis' treat young people as individual economic decisionmakers, ignoring the ways in which they are deeply embedded in networks of family and social relations that both enable and constrain them (IDS, 2016). The reflections undertaken in the world of the peasant movement, on the contrary, are firmly sited in the context of the family. They seek to develop responses that empower rural communities as a whole, including the youth, to address the structural issues that affect them all. From a collection of interviews conducted between 2009 and 2013 the vision that emerges is one of young people 'between two worlds'. Many leave the villages as soon as the season's work on the family plots is finished, living most of the year in the cities but remaining attached to their families (GRAD/ROPPA, 2014). The difficulties they encounter in obtaining access to credit and land - aggravated by agricultural development orientations that stimulate land grabbing - are among the most important structural problems they encounter. Support for the kind of productive and value-adding activities that they could carry out in their own rural territories is lacking. The lack of amenities and infrastructure in rural areas - the result of decades of neglect by public policies and investment - intensifies the attraction of the urban areas.

Relations within the family are also evolving, in different and sometimes apparently contradictory ways (GRAD-S, 2013). While in some cases young people feel that their families and fathers do not accept the evolution of their roles within the family farm, in others the heads of family understand that they can't control everything and are playing the role of mediators while acknowledging that the young people are the pillars of the family farm (GRAD/ROPPA, 2014). The weakening of the authority of the fathers, leaving young people without a strong reference point in the eternally difficult navigation of adolescence, has led one attentive observer of West African rural realities to wonder whether the 'problem' might not be one of the fathers rather than of the young people (Barbadette, 2016).

The hypothesis that irregular migration to Europe represents a rational strategy on the part of those who undertake it which can be folded seamlessly into the win-win-win circular migration touted by pro-business migration managers (Brboric, SI, p. 19) is not substantiated by West African testimony. A Senegalese peasant leader has described the process in these terms:

The accentuation of poverty and inequalities is key. People react differently. Many accept to fight poverty adopting a variety of strategies. Others, feeling that nothing will change the situation, decide to leave, comforted by images suggesting that things are better in Europe. So they don't worry about how to get there and what to do. The problem is just to get there. ${ }^{12}$

Other interviews testify to the sense of fear and danger that accompany the trip, the difficulties encountered, as well as the efforts made by returned migrants to sensitize other young people to the down side of migration (GRAD/ROPPA, 2014).

The strategies and policies advanced by West African rural people and their organizations are dramatically different from those proposed from outside. The Senegalese leader referred to above reported that he had turned down a proposal from a European cooperation programme that offered to pay his village organization a certain sum for each returned migrant whom they agreed to welcome into the community accompanied by his/her individual installation project. 'You can imagine what kind of conflicts an approach like this would create!' he stated. 'Instead, the cooperation programme should support my organization directly to transform agriculture in the territory. When people see there is an economy that works they will return on their own initiative.'

For organizations like the FONGS, the CNCR and ROPPA the way forward is family farming, not agribusiness and agricultural corridors, but family farming that finally receives the support it merits. 
Their positions are backed up by action. Building on the experience of the FONGS and the CNCR, ROPPA is now extending to countries throughout the region a network of Observatories of Family Farms. Using the data collected for advocacy purposes, the CNCR has been able to demonstrate that family farms are responsible for feeding the majority of the population of the country (CNCR/ FONGS, 2010). Subsequent monitoring exercises have looked specifically at the question of facilitating the installation of young farmers (CNCR, 2017). In Senegal family assemblies are held with support from peasant animators to negotiate collective strategies that take into account the interests of all members, including the women and young people. In 2012 the CNCR, like other national peasant platforms in West Africa, established a Youth Council to strengthen young peoples' participation in the governance of the organization. Among its innovative initiatives is a programme of 'mentoring' which seeks to ensure intergenerational continuity by pairing young people with leaders who dedicate time to sensitizing them to the history of the peasant movement, the challenges of agriculture, and the attitudes and behaviour necessary to become good leaders (CNCR, 2015).

ROPPA's monitoring work has identified promising sectors for young people and women (vegetable production, poultry production, sheep fattening and processing of agricultural products) and key conditions for retaining them in the family farms: access to natural and material resources, possibility of achieving adequate revenues through access to remunerative markets, access to appropriate credit, technical support and training, recognition and valorization of the status of 'peasant', and amelioration of living conditions in rural areas (ROPPA, 2016). A regional workshop organized by the CNCR and ROPPA in Dakar in September 2017 assessed the weaknesses of official programmes targeting young people, which most often adopt inappropriate models, fail to involve local communities and producers' organizations, and do not address issues of access to land and credit (CNCR, 2017). A major advocacy effort is now being directed towards ECOWAS and its member states to establish strategies and funds for the installation of young people in agriculture based on 'a new paradigm, considering youth employment as a motor for transforming family farming while respecting its multifunctionality and the values on which it is based' (ROPPA, 2018, p. 12). ROPPA's strategy addresses the need for changes in public policies and investments to make agriculture a more remunerative proposition and rural territories more attractive places in which to live. But it also acknowledges the necessity of enhancing the status and perception of young people and their participation in decision-making in their families and organizations, and foresees measures to bring this about.

\section{Conclusion}

The evidence is on the side of West Africa's family farms and territorial food systems, not the EU's mirage of 'modern' agrifood value chains led by European investors transforming rural young people into entrepreneurs as fast as African societies can engender them. One source of this evidence is the UN Committee on World Food Security (CFS), reformed in 2009 to become the only global food policy forum in which organizations representing those directly affected by the policies under discussion participate on the same footing as governments (McKeon, 2015). ROPPA is a key actor in the autonomous Civil Society Mechanism that interfaces with the CFS. Policy recommendations on investing in smallholder agriculture and enhancing small-scale producers' access to markets adopted by the CFS from 2011 to 2016 have officialized the reality that these producers are responsible for meeting $70 \%$ of the world's food needs and making $90 \%$ of all investment in agriculture. What's more, $80 \%$ of the food consumed world-wide does not transit through the global value chains of 'modern' supply systems. On the contrary, it is traded in territorially-embedded markets which are 
directly linked to local, national or regional food systems, more inclusive of young people and women, more remunerative for small-scale food producers, and which enable a greater share of the wealth created to be retained and redistributed within the territorial economies (CSM, 2016).

In the name of modernization and development the corporate food regime has taken possession of terms such as 'change', 'evolution', 'innovation', cloaking African small-scale producers in a mantle of archaic, immobile subsistence. This is belied by the remarkable capacity of West African family farms to recompose the multiple fractures to which they have been subjected since the advent of colonialism and continue to feed their societies despite almost total lack of support from public policies and ODA. The obtuseness of excising the economic dimension of human activity from the social and cultural is increasingly evident in societies in which combined economic and social malaise is destituting traditional political parties, now void of values and visions, and generating cultures of xenophobia in a globalized world. The bankruptcy of the corporate food provisioning mode is hard to deny, with food insecurity, malnutrition and food-related health issues on the rise along with environmental damage and climate change - despite the efforts of corporate spin doctors to serve up climate-smart agriculture and digitalized diets. With fourteen of the fifteen ECOWAS countries estimated to be off-track to reach SDG1 by 2030 the dominant paradigm is clearly on shaky ground (https://worldpoverty.io/).

What are still solidly in place are the power relations that link capital and governing elites in Europe and Africa, but even here there are signs of ambiguity. African authorities are eminently susceptible to being co-opted by the blandishments of corporate-concocted investment programmes such as Grow Africa or the New Alliance for Food Security and Nutrition, and giving in to pressure to accept trade and investment agreements which are clearly detrimental to African economies and regional integration. At the same time, they are able to research and publish policy documents for the transformation of African agriculture which are largely in line with the peasant movements' analyses and proposals (NEPAD, 2013).

On the European side it could be argued that the EU and its member states are drifting dangerously from their time-honoured positions of policy incoherence to something even more uncomfortable. Policy incoherence can be defined as a situation where one policy - usually 'soft', morally irreprehensible, human rights-based, easily relegated to the status of pious declaration - is contrasted, and normally overcome, by 'hard', 'serious' policies promoted by powerful economic interests whose support is considered to be essential by the governing authorities. What seems to be emerging now is a shift to what might be termed 'policy ambivalence'. This awkward condition could be described as a situation where two different policy packages with diametrically opposed impacts are being promoted by two different 'stakeholder' groups - in this case the usual powerful economic interests, on the one hand, and strident and politically opportunistic defenders of European security on the other - both of whose consensus is considered to be essential by the governing authorities. So the EU finds itself pushing forward with policies oriented towards using public funds to subsidize investments by European enterprises promoting approaches to agricultural development and food provisioning that will further penalize African rural economies, disrupt the family units that guarantee social stability, and fuel the flow of young people to Europe. The very outcome that is stimulating xenophobic populist reactions and creating serious political difficulties at both national and regional levels in Europe today.

Policy ambivalence is a headache for the authorities. But it could open up opportunities for civil society and social movement activists to defend both the rights of migrants and the kinds of policies and investments that are needed to give rural people choices in their countries of origin. This would require building convergences among organizations of different kinds in Africa and in Europe: 
small-scale producers and their communities, young people, migrants, agricultural workers, consumers, the diaspora. It would require mobilizing support from engaged academics to help analyse a complex situation and develop cogent critiques and proposals. Alliances would need to be built with civil society, parliamentarians, media and others who can help to take advantage of a moment of political opportunity for advocacy with both European and African governments. This kind of exercise has been carried out in the past, notably around the neoliberal Economic Partnership Agreements (EPAs) that the EU began to negotiate with the regional economic organizations of 'ACP countries $^{13}$ in 2000. Eighteen years later ECOWAS has still declined to sign a regional EPA thanks in no small part to effective advocacy and participation in the negotiations by ROPPA and other West African civil society networks. In this process a space bringing West African peasant organizations together with European CSOs was crafted based on long-standing relations of partnership and trust, and a common advocacy platform was formulated privileging the West Africans' perceptions and claims (McKeon \& Maes, 2008).

Applying this kind of strategy in the case of migration would require more effort for a number of reasons. The European CSO advocacy scene is dominated by NGOs privileging attention to defending Africans' right to mobility and NGOs' right to save lives. As with the civil society actors involved in the High Level Dialogue on Migration and Development, they lack a common understanding of just what the 'root causes' of migration are (Toksoz, SI). As we have seen, ROPPA prefers to frame its claims in terms of promoting employment opportunities for young people in the context of family farming rather than those of contrasting migration. ROPPA has participated in some meetings organized by the Pan African Network in Defense of Migrants' Rights, a Mali-based member of the Global Coalition on Migration. However, it has refrained from following the global processes not out of lack of solidarity with migrants' rights but simply because the amount of time, energy and resources required for a social movement to engage meaningfully at global level is so extensive as to require careful prioritization. It is not surprising that most small-scale producer members of the food sovereignty movement have privileged engagement with spaces like the Committee on World Food Security, whose reform they helped to shape and where they participate fully in intergovernmental negotiations in an autonomous and self-organized mode, and the UN Human Rights Council where a declaration on the rights of peasants and a treaty regulating transnational corporations are under negotiation. The absence of these actors may help to explain why there has been relatively little discussion of 'root causes' in the Global Forum on Migration and Development Civil Society Days (Toksoz, SI, p. 13). ROPPA has also participated in World Social Forum processes, with a particular presence at the 2011 edition in Dakar where migration was a key theme. The enduring Latin American imprint on the World Social Forum on Migrations, however, could militate against their sustained engagement (Delgado Wise, SI, p. 12).

In spaces at all levels around the world social actors are fighting against the manifold forms of violence practiced by neoliberal globalization, corporate concentration and financialized capitalism. They are constructing more equitable and inclusive alternatives and challenging dominant narratives with evidence culled from lived experience. Under the pressure of the current wave of authoritarian nationalistic populism that is, itself, a reaction to globalization, there is an increasingly strong call for both horizontal and vertical convergence among movements and struggles that adopt different entry points but are conducting the same struggle. Efforts to reform the World Social Forum on Migrations point in that direction (Delgrado Wise, SI, p. 12). So do the Civil Society Mechanism's determination to introduce the issue of migration into the agenda of the Committee on World Food Security, an autonomous process to deepen strategic analysis of the current phases of capitalism and democracy currently promoted by activists from different movements and engaged academics, and countless 
other connecting processes. The point is not to bring everyone under the same tent, but to build increasingly broad and deep strategic networking among different social actors who come to recognize themselves as allies in whatever space they may be mobilizing and whatever the diverse terms they may use to frame their objectives and project their visions.

\section{Notes}

1. A significant exception is the more broadly framed European Coordination Via Campesina working document on migration and wage-labour (2017).

2. This section draws on McKeon et al. (2004) and McKeon (2005).

3. See Dupriez (1980) for extremely interesting calculations in this regard.

4. Mamadou Dia, 1957, quoted in Lecomte (2001).

5. Burkinabé peasant quoted in Construire ensemble (1981).

6. In good part due to their acceptance of bank loans during the fluidity boom of the 70s to fund the 'modernization' of their economies, according to Western development dogma of the time, by investing in industrialization and mechanization initiatives that most often turned out to be 'white elephants'.

7. Cote d'Ivoire, Ghana, Nigeria, Senegal.

8. Bernard Lédéa Ouedraogo.

9. Famara Diedhiou.

10. Burkina Faso, Ethiopia, Mozambique, Niger, Senegal and Zimbabwe.

11. $90 \%$ of the EUTF funds come from ODA, in particular the European Development Fund.

12. Personal communication, 4 February 2018.

13. Africa-Caribbean-Pacific, the former colonies of EU members.

\section{Disclosure statement}

No potential conflict of interest was reported by the author.

\section{References}

Achebe, C. (1959). Things fall apart. London: William Heinemann.

Adepoju, A. (1998). Linkages between internal and international migrations: The African situation. International Social Science Journal, 50(157), 387-395.

Ba, C. O. (2007). Barca ou barzakh: La migration clandestine sénégalaise ver l'Espagne entre le Sahara Occidental et l'Océan atlantique. Retrieved from https://afrique-europe-interact.net/285-2--text-zusenegal.html? 
Barbadette, L. (2016). Jeunesse rurale africaine: deux regards à 35 ans de distance. Inter-réseaux, 11((Jan). Retrieved from http://www.inter-reseaux.org/publications/revue-grain-de-sel/71-jeunesses-ruralesafricaines/article/jeunesse-rurale-africaine-deux?lang $=\mathrm{fr}$

Bates, R. H. (1981). Markets and states in tropical Africa. The political basis of agricultural policies. Berkeley: University of California Press.

Cissokho, M. (2009). Dieu n'est pas un paysan. Bonneville: GRAD. Paris: Présence africaine.

Cissokho, M. (2018). To arms citizens, we're being invaded! Stop migration. Retrieved from http://www. terranuova.org/news-en/to-arms-citizens-we-re-being-invaded-stop-migration

Civil Society Mechanism. (2016). Connecting smallholders to markets: An analytical guide. http://www.csm4cfs. org/connecting-smallholders-markets-analytical-guide/ Retrieved from http://www.csm4cfs.org/ connecting-smallholders-markets-analytical-guide/

CNCR. (2015). Renforcement des connaissances et des compétences ainsi que développement des talents de la jeunesse pour améliorer la sécurité alimentaire et la nutrition. Programme de mentorat 'Ndiangaane' du collège des jeunes du CNCR. Rome: Committee on World Food Security. Retrieved from www.fao.org/ CFS42_Youth_Africa_NDIANGAANE.pdf

CNCR. (2017). La question de l'installation des jeunes agriculteurs ruraux. Rapport de suivi des exploitations familiales 2015-2016. Retrieved from http://www.fongs.sn/IMG/pdf/cncr_rapport_suivi_des_ef_2015-2016. pdf

CNCR/FONGS. (2010). Comment les exploitations familiales peuvent nourrir le Sénégal. Retrieved from www. fongs.sn/spip.php?article38

CONCORD. (2017a). EUTF for Africa: Partnership or conditionality? Retrieved from https://concordeurope. org/2017/11/22/eu-trust-fund-africa-ep-event/

CONCORD. (2017b). Mixing ends and means. What role for (which) private sector in agriculture and food \& nutrition security? Retrieved from https://concordeurope.org/2017/11/30/private-sector-in-agriculture/

Counterbalance. (2017). The External Investment Plan: innovative instrument or dangerous blueprint for EU development policy? Retrieved from www.counter-balance.org/wp-content/uploads/CB_EIP_d.pdf

De Haas, Hein (2007). The myth of invasion - irregular migration from West Africa to the Maghreb and the European Union, International Migration Institute Research Report. Oxford: International Migration institute.

Dupriez, H. (1980). Paysans de l'Afrique noir: quels savoirs pour quelle révolution agraire? Nivelles: Terres et Vie.

ENDA. (1985). Initiatives paysannes aux Sahel. Dakar: Author.

European Commission. (2017). EU European External Investment Plan Fact Sheet. Retrieved from https://ec. europa.eu/europeaid/eu-external-investment-plan-factsheet_en

European Commission. (2018). European Fund for Sustainable Development Guarentee, Investment Window: Sustainable Agriculture, Rural Entrepreneurs and Agribusiness. Retrieved from https://ec.europa.eu/efsdguarantee-windows-agriculture_en

European Coordination Via Campesina. (2017). Migrations and rural areas in Europe. Retrieved from www. eurovia.org/2017-04-28-ECVC-Document-on-Migration.

Fall, B. (2002). Social History in French West Africa: Forced Labour, Labour Market, Women and Politics. South-South Exchange Programme for Research on the History of Development (SEPHIS) and the Centre for Studies in Social Sciences, Calcutta (CSSSC). Amsterdam/India, 2002.

FAO. (2016). Migration, agriculture and rural development. Addressing the root causes of migration and harnessing its potential for development. Rome: Author.

Flahaux, M.-L., \& De Haas, H. (2016). African migration: Trends patterns, drivers. Comparative Migration Studies, 4(1). Retrieved from https://comparativemigrationstudies.springeropen.com/articles/10.1186/ s40878-015-0015-6

FONGS. (1991). Document de synthèse des restitutions des auto-évaluations et des conclusions de l'Assemblée Générale. Thiès: Author.

Gent, S. (2002). The Root Causes of Migration. Criticising the Approach and Finding a Way Forward. Sussex Migration Working Paper no. 11. University of Sussex.

GRAD/ROPPA. (2014). Jeunes ruraux en Afrique de l'Ouest. Bonneville: GRAD.

GRAD-S. (2013), En lieu rural d'Afrique de l'Ouest: vers d'autres façons de décider entre les ainés et les jeunes. Bonneville: GRAD. 
Gyapong, A. Y. (2017). Family farms, land grabs and agrarian transformations: Some silences in the food sovereignty discourse. $5^{\text {th }}$ International Conference of the BRICS Initiative for Critical Agrarian Studies.

Hydén, G. (1980). Beyond Ujamaa in Tanzania: Underdevelopment and an uncaptured peasantry. Berkeley: University of California Press.

Illife, J. (1987). The African poor, a history. Cambridge: Cambridge University Press.

Institute of Development Studies. (2016). Young people and agriculture in Africa. Sussex: Author.

Lecomte, B. (2001). Une fresque esquissant les strategies des acteurs de l'aide international dans le domaine de l'organisation des paysans en Afrique de l'Ouest (1958-2000). Mimeo.

McKeon, N. (1988). Synthesis of the African national reports. Rome: The Image of Africa Project. Mimeo.

McKeon, N. (2005). Poverty reduction in the Sahel: What do farmers have to say? In Bocella \& Billi (Eds.), Distribution des révenues, inégalités et politiques de réduction de la pauvreté (pp. 173-202). Paris: Karthala.

McKeon, N., \& Maes, M. (2008). What is the impact of European trade policies on African agriculture and African farmers? Advancing African agriculture. Monitoring exercise by European CSOs (pp. 9-13). Retrieved from www.ukfg.org.uk/files/AAA_2008_CSO_background_reader.pdf

McKeon, N., Watts, M., \& Wolford, W. (2004). Peasant associations in theory and practice. Geneva: UNRISD.

NEPAD. (2013). Agriculture in Africa. Transformation and outlook. Johannesburg: Author. Retrieved from http://www.nepad.org/print/6373

Organisation of African Unity. (1981). Lagos plan of action for the economic development of Africa. Addis Abeba: OAU.

Robin, N. (2007). Migrations en Afrique de l'Ouest, une longue histoire. Panorama des migrations en Afrique de l'Ouest, Grain de Sel, no. 40, Septembre-Novembre 2007.

ROPPA. (2016). Synthèse et conclusions du premier rapport de l'OEF/ROPPA. Ouagadougou: Author.

ROPPA. (2018). Stratégie régionale d'insertion/installation des jeunes dans le secteur agrosylvopastorale et halieutique. Ouagadougou: Author. en construction.

Sjoberg, J. (2008), Dissecting the 'Root Cause' Approach. A Discourse analysis of the Long Term European Migration Policy. Lund University. Retrieved from https://lup.lub.lu.se/student-papers/search/publication/ 1459213

Skeldon, R. (2014). Migration and development. A global perspective. Abingdon-on-Thames: Routledge.

Watts, M. J. (1983). Silent violence. Food, famine and peasantry in northern Nigeria. Berkeley: University of California Press. 


\title{
Postscript: The Global Compact for Migration: what road from Marrakech?
}

\author{
Carl-Ulrik Schierup, Raúl Delgado Wise, Stefan Rother and Aleksandra Ålund
}

Chapters in this volume have followed different fora and deliberations on the global governance of migration initiated by the UN High Level Dialogue on Migration and Development (UNHLD) in 2006 up till and including the summit of the Global Forum on Migration and Development (GFMD) in Berlin 2017. The focus of the book is on the impact of civil society groups and organizations on these processes concerned with the formulation of an overall normative framework for the governance of migration.

This postscript addresses venues taking place after the Berlin GFMD. It revolves around the idea of 'invited' versus 'invented' spaces (Chapters 2, 6 and 7). Invited spaces stand for positions and platforms occupied by civil society organizations (CSOs) or non-governmental organizations (NGOs), embodied in a general neoliberal idea of 'participatory governance' in terms of state-market-civil society partnerships. Invented spaces are in contrast organizational and ideopolitical positions or counterhegemonic platforms occupied by contestative movements which through their collective action confront the status quo (Chapter 6). In the present text invited spaces refer to civil society groups in their position as participants within intergovernmental and international fora for deliberation on migration management. Invented spaces refer to independent civil society platforms for the development of strategies and action aimed at inclusive social, labour, citizenship and human rights of migrants.

From this perspective we relate in the following to the Global Compact for Safe, Orderly and Regular Migration (GCM) agreed upon by governments on an intergovernmental conference 10-11 December 2018 in Marrakech and formally adopted by the General Assembly of the United Nations on 19 December 2018. ${ }^{1}$ Our focus is on civil society's perceptions of the GCM, and potentials for following up intentions of the compact through 'invited spaces' for dialogue with governments and international organizations on the road from Marrakech. We continue with a short presentation of professed 'invented spaces' for solidarity mobilization of social movements and their strategies for social inclusion: the People's Global Action on Migration, Development and Human Rights (PGA), the Permanent Peoples Tribunal (PPT), La Via Campesina, Churches Witnessing With Migrants (CWWM) and the World Social Forum on Migration (WSFM).

\section{Predicaments of the Global Compact}

The Intergovernmental Conference to adopt the GCM was preceded by a particularly dense combination of gatherings involving a plethora of stakeholders and often overlapping spaces, which was termed the 'migration week'. At its core was the yearly meeting of the GFMD, consisting of the Government Meeting (6 and 7 December), the Civil Society Days (4 and 6 December) and the Common Space (5 December) explicitly designed as an 'invited space' for the deliberation between 
civil society and governments. As every year since 2006 (Ålund and Schierup Chapter 6) multiple stakeholders came together for the PGA in Marrakech, 8-9 December, in between the GFMD and the concluding GCM intergovernmental conference (10-11 December). Numerous side events were organized in the 'migration week', focusing on issues concerned with migration, development and human rights. In the weekend before the GCM conference (and thus parallel to the PGA) 60 side event sessions took place. In addition, on the same dates full conferences were held such as the Tenth Diaspora Development Dialogue (DDD10), The Role of the African Diaspora in the Implementation of the Global Compact on Migration and as Catalyst for Sustainable Development (8-9 December), a Migration Youth Forum on the GCM (8-9 December) and the conference Euro-African Crossroad of Migration and Development (8-9 December). ${ }^{2}$

The importance of cities for the implementation of policies of migrant inclusion was highlighted by the launch of the Mayors Migration Council on 8 December at the fifth Mayoral Forum on Human Mobility, Migration and Development, where representatives from over 70 cities debated and endorsed a mayoral declaration, delivered to the GCM conference (UCLG - Committee on Social Inclusion 2018). The organizers of the Mayoral Forum had decided to 'dock onto' the GFMD process since they considered it as a major space for multiple stakeholders to deliberate on migration in a non-binding, informal setting.

Likewise, the GFMD can be seen as a venue for 'state-socialisation', where for now more than a decade states have found a space for exchanges on the issue with each other, but also increasingly with civil society actors (Chapter 5 and Rother 2018). It can also be seen as a venue that has been central (besides the more immediate pressure felt by states through the so-called 'migration crisis') in paving the way towards the 2016 New York Declaration for Refugees and Migrants ${ }^{3}$ and its call to establish two global compacts: one on refugees and one on (mostly labour) migration (the GCM).

The GCM is a non-binding document, meant to express a common roadmap for governments in the management of a so-called 'safe, orderly and regular migration', yet confirming the 'sovereign right of States to determine their national migration policy' (United Nations 2018). It rests professedly on the Universal Declaration of Human Rights and other UN human rights declarations and documents, including the Agenda for Sustainable Development Goals (Chapter 3). Tellingly, though, the reference to the - binding - 1990 International Convention on the Protection of the Rights of All Migrant Workers and Members of Their Families ${ }^{4}$ (ICRMW) is only made in a footnote.

In effect, the compact has been met by highly different responses.

A major - and seemingly concerted - campaign has been launched by groups from the far-right spectrum such as the Identitarian Movement (Identitäre Bewegung). While the broader public rarely took notice of the compact process even when the final draft was agreed upon in July 2018, numerous campaigns and conspiracy theories were launched on social media. Among the allegations was a criticism of an allegedly toxic pro-migration bias of the compact, its professed emphasis on respecting and implementing human rights of migrants, its perceived threats to state sovereignty and an alleged 'censorship' of critical voices. An early indicator of things to come was the United States' withdrawal from the work on the compact in November 2017 - right before a first stocktaking meeting took place in Puerto Vallarta. Other states, including Australia, Chile, the Dominican Republic, together with EU member states under neo-conservative rule, including Austria, Hungary, Italy, Bulgaria, Poland, the Czech republic and Slovakia, have followed suit and abstained from supporting the compact in December 2018, asserting that the compact invites new floods of culturally extraneous migrants, causing the death knell of incumbered nations. It is an indicator of the major impact of the far-right campaign that most of these countries (except Hungary) had still supported the GCM when the final draft had been agreed upon just a few months earlier. An especially telling 
case was the one of Austrian chancellor Sebastian Kurz, who had welcomed the compact when the process was started and was fully involved in the negotiations when Austria chaired the EU. But in response to the campaign of the 'Identitarian Movement' (which is particularly strong in Austria) and under pressure from his right-wing coalition partner, Kurz made a 180 degree turn and suddenly saw the GCM to be 'diametrically opposed to Austria's interest'. The incoming neo-fascist government of Brazil declared (as of December 2018) that it intended to withdraw from the compact.

Accordingly, the very language of human and migrant rights, appropriated by the GCM, has provoked populist regimes, parties and movements on the extreme right, and it has aroused a storm of propagandistic remonstrations. The appropriation of a human rights discourse $\mathrm{e}^{5}$ by the GCM could, however, at the same time be seen as a victory for a global civil society's thrust for a rights-based governance on migration, pushed along in deliberations with governments and international organizations, from the first UNHLD in 2006 until the adoption of the global compact, today. However, notwithstanding the compact's proclaimed subscription to a human rights agenda, the reception of the GCM among the numerous civil society delegates, gathered in Marrakech from all over the world in December 2018, was far from unanimously positive.

Certainly, a 'joint message', addressed by 90 CSOs and NGOs from across the world to the States at the concluding Intergovernmental conference 10-11 December, endorsed the GCM as 'a historic achievement': a 'comprehensive framework for multilateral cooperation on international migration ... [with] potential to make a positive impact on the lives of millions of ... fellow human beings who move in search of a life of dignity and security for themselves and their families' (ICVA 2018). ${ }^{6}$ This unconditional affirmation could be seen to lend the GCM the status of a hegemonic accord, ostensibly legitimized by a consensual 'global civil society'.

Yet, many speakers at the Marrakech Civil Society Days expressed a critically pragmatic view of the GCM, seeing the compact as perhaps the best document possible under today's adverse political and social conditions. An often-heard sentiment was that the provisions of the compact represented 'a floor, not a ceiling'. From this perspective the compact's actual meaning and importance is seen to depend on the degree to which global, regional and national CSOs will be able to mobilize and hold the governments responsible for the implementation of its perceived positive aspects. The key question forward is, argued Mamadou Goïta, from the Pan African Network in Defence of Migrant Rights (PANiDMR) and co-chair of the GFMD Civil Society Days, 'how to leverage a global multilateral agreement and networks to impact national debates'? (PICUM 2018). In the Introductory Plenary Assembly of the PGA event in Marrakech, 8 December 2018, Goïta addressed the GCM and its impact on Migration Policies condensed in the question 'Migration Crisis or Crisis of the Political and Economic System?' Describing the position of civil society in negotiations during the GCM preparatory process Goïta noted that 'We were observers, not negotiators'. He emphasized that the GCM exposes 'many weaknesses and some strong points'. Africa and Asia are weakened and divided, he noted, and must be 'pragmatic'. The compact is, from this perspective, as maintained on the home page of the Platform for International Cooperation on Undocumented Migrants (PICUM 2018), seen as a key moment and opportunity to 'shift the narrative' on migration: that is, by implication, using relevant follow-up mechanisms of the GCM as invented spaces for further dialogue and negotiation to be taken advantage of by civil society on the road from Marrakech.

PANiDMR and PICUM are both members of the Global Coalition on Migration, formed by 20 mainly migrant-led organizations. The Coalition has been spearheading civil society's participation as stakeholders in the intergovernmental processes leading to the $\mathrm{GCM}^{7}$ (with which it shares the same acronym). Since the New York Declaration in 2016 the Coalition and its member organizations have been engaged in global and regional consultations and advocacy with governments and 
international organizations on the GCM. There was indeed an awareness that the GCM does not necessarily by itself result in better human rights protection. ${ }^{8}$ Related to this, it must also be noted that the so-called 'zero draft' of the GCM, issued in early 2018, was clearly informed by the language of and issues on the agenda of migrant rights organizations. Not surprisingly, several of these issues were 'watered down' with each draft emerging from the intergovernmental negotiations. Notwithstanding observations that the 'compact falls short in several important areas and in some aspects steps away from current international standards and regional practice, ${ }^{9}$ most members of the Coalition endorsed the final draft of the GCM as well, since several issues relevant for their agenda were perceived to have survived successive deliberations, albeit sometimes under less obvious framings. The actual meaning of the Compact is thus, from this perspective, seen to depend on the degree to which global, regional and national CSOs will be able to mobilize on all relevant levels, to hold governments responsible for the compact's actual implementation, and on the ability to continue successful deliberations on the extension of its coverage into additional realms of human, labour and citizenship rights.

A more resolutely critical position is, for example, held by the regional-European Transnational Migrant Platform-Europe (TMP-E), likewise member of the Global Coalition on Migration. TMP-E is, among other, contesting the non-binding character of the GCM and the criminalization and detention of migrants and refugees. In the consultations following the New York Declaration the TMP-E took a markedly robust position on human and labour rights. Thus, a statement by the TMP-E, submitted 2 October 2017 to the Regional Consultation in Europe on the GCM, ${ }^{10}$ stressed, among other, the exigency of bringing discriminatory, divisive and imperilling politics and practices of 'temporary migration programs' to an end. That is the new 'normal' of a global politics of 'apartheisation', as we describe it in this volume (Chapter 1), yet an issue hardly touched upon in the final text of the GCM. Together with other networks a mobilization questioning the GCM is being planned by TMP-E in Brussels (April 2019), with activities both inside and outside the European Parliament, ahead of the upcoming parliamentary elections.

A noteworthy position memo concerning inherent weaknesses of the GCM was addressed to the concluding intergovernmental GCM meeting on 10-11 December (RSMMS 2018) by the Mediterranean - Subsaharan Migration Trade Union Network (RSMMS). The RSMMS is a coalition of 24 trade unions from three regions (Southern Europe, the Maghreb and Francophone West Africa). The RSMMS emphasizes in their address to the governments the fundamental character of 'the right to migrate', the 'right to decent work' and the protection of workers, independent of their legal status. It stresses the fundamental role that should be played by unions in struggling, in the context of the GCM, for decent work for workers of the world. This pertains to the inviolable rights of millions of workers inscribed in binding UN conventions, in particular relating to the most vulnerable, including undocumented migrant workers operating in the informal sector. In line with this the RSMMS challenges the GCM's feeble protection of migrant workers, and the absence in the GCM of a range of essential social rights and services that should be available to all migrants. It criticizes a weak stance of the compact concerning the principle of non-criminalization of irregular migrants and the absence of respect for the principle of non-refoulement. The network expresses further its discontent with the absence in the compact of a section specifically dedicated to the governance of labour rights as recommended by the ILO (International Labour Organization) in its input for the GCM. This includes, it is stressed, 'social dialogue', 'tripartism' and freedom of association and collective bargaining agreements. In line with this the RSMMS reaffirms the fundamental importance of struggling for the affirmation of binding conventions of the United Nations, not least the ICRMW. 
There is indeed a contrast between the strong presence in the 1990 ICRMW and the 1998 ILO Declaration of Fundamental Principles and Rights at Work (applying universally to all ILO Member States) of protection of labour rights for all, of rights to freedom of association and collective bargaining, and the duties of states to protect migrant workers' inclusion into or their formation of labour unions as well as other forms of collective organization, and the almost complete absence of these principles in the GCM. It dovetails with a progressing marginalization of the ILO in the GFMD/GCM processes and the matching reinforcement of the role of the IOM, of which different aspects are discussed in Chapters 3, 6 and 8 of this volume. It indicates an inherent weakness of the GCM framework as a potential platform of 'invited spaces' for migrant and civil society impact: a problem of 'participatory governance' that we have discussed at length across the contributions to the book. It brings to light the business-friendly character of the GFMD/ GCM process (Chapter 3), blocking the introduction of clauses on migration that would limit flexploitation of migrant workers and thus the space of manoeuvre of multinational corporations and their globally extended networks (Chapter 2).

This potentially retrogressive predicament of the GCM was particularly powerfully brought out in an Appeal of 18 December for Equal Rights and Social Justice, circulated by the Euro-Moroccan chair of the 2018 PGA in Marrakech on behalf of more than 30 North African and European migrant and migrant supportive organizations (MDDC 2018). ${ }^{11}$ The ICRMW represented, it is argued, a qualitative leap ahead in its capacity of an international judicial instrument but unfortunately mainly signed by states of the South. However, in the Global Compact for Safe, Orderly and Regular Migration the rich countries have found a means to marginalize and counteract the 1990 convention.

On a similar stance, former ILO Senior Migration Specialist and Global Migration Policy Associates (GMPA) President Patrick Taran (2018) argues that the confirmation of the GCM amounts to no less than a major regime change, concerning the overall existing legal, policy, institutional and practical governance system.

In historical normative and political terms the GCM logic, content and impact is 'regime change' away from the binding application and rule of law implementation of the global normative system of universal, inalienable, indivisible Human Rights - including labour rights/international labour standards to all - in particular to all migrants ... As a non-binding declarative instrument explicitly about migration management, the GCM presents an agenda for arbitrary executive authority at the exclusion of equally engaging the parliamentary legislative role and the roles of the judiciary ... The overall terms of safe orderly and regular migration have no accountable international normative definitions, in contrast to terms of rights, justice, equality/non-discrimination and social protection, which are normatively defined and recognized widely in international law and jurisprudence as applicable to all migrants. The non-normatively bound terms translate to and indeed reinforce the absence of enforceable rights protection, promotion and fulfilment of obligations at the national level, never mind international accountability.

\section{Another compact is possible! Voices for counterhegemonic solidarity}

Critical voices of a contestative civil society, of which a few are referred to above, call for the reinforcement of genuinely autonomous 'invented spaces' for organization, cross-sectoral multilevel strategizing (local, national, transnational, regional and global) and CSO action. It is about building broad solidarities opposed to a hyper-exploitative 'management of migration' in a world of walled states. 
One potentially important invented space remains the PGA (Peoples Global Action for Migration, Development and Human Rights). In Chapter 6 of this volume we have argued that, in its position as an adjunct to recurrent government-driven fora, the PGA has suffered from civil society fragmentation and co-optation, and it has demonstrated a lack of transformative strength to defy core stratagems of a neoliberal corporate-driven global governance hegemony. Yet, the PGA venue in Berlin 2017 seemed to indicate a change towards a more dynamic approach. The PGA venue in 8-9 December in Marrakech further indicated the PGA's continued, or perhaps recuperated, character of an open 'invented space' with critical potential for engendering contestative political subjectivity and counterhegemonic activism. Debates in thematic workshops delved into essential issues of root causes and structurally conditioned consequences of migration. They evolved around themes such as undocumented migrants in the present moment of crisis and political and economic restructuring, migrant women's human rights, social movements and gendered migrant labour in the global economy, economic roots of xenophobic backlash and strategies for building solidarity between national and migrant workers, the quandary of securitization and walled states, extractionism and land grabbing as drivers of migration, forced migration and the impoverishment of communities in a context of the dismantlement of public services in the global South as well as North.

The road from Berlin 2017 and from Marrakech 2018 signifies the importance of global civil society summits like the PGA as incubators for a wider mobilization of critical counterhegemonic movements. Parallel to participation in the civil society consultations for the Global Compact, the TMP-E, co-chair of the Berlin PGA, organized together with the $\mathrm{PPT}^{12}$ a series of Hearings on the unprecedented violations with impunity of the human rights of Migrant and Refugee Peoples throughout 2017-2018. These Hearings held in Barcelona, Palermo, Paris and London ${ }^{13}$ - the outcomes of which were brought to Marrakesh - laid the ground for an identification of a 'necropolitics $^{14}$ and crimes against humanity by the European Union (EU) and its member states causing continuing mass deaths in the Mediterranean and Aegean seas. According to Jille Belisario of the TMP-E, it is the PPT and not the Global Compact which is robustly defending the inalienable human rights of migrants and refugees - a position also strongly advocated by the FMAS (Moroccan Steering Committee for the PGA and the Maghreb Social Forum). ${ }^{15}$ This contestation was moreover strongly articulated in the Peoples Summit, organized by La Via Campesina in Marrakesh (8-9 December) with delegates from all continents as well as a broad participation by movements from Morocco and the Maghreb region. The Peoples Summit proposed an Agreement on an International Pact of Solidarity and Unity of Action for The Full Rights of All Migrants and Refugees and outlined a proposal for alternatives as its response to the GCM. ${ }^{16}$

A further space for deliberations of migrant rights networks and their counterhegemonic resistance to global migration discourses and 'management' (see Chapter 9) was the ninth international consultation of CWWM held in Marrakech, 6-8 December. The gathering brought together migrants and representatives from faith-based organizations, service providers and migrant groups from 22 countries. The aim of the CWWM is to ground global deliberations in the lived experiences of migrants and thus link the grassroots to the global level. In Marrakesh, this was achieved by two means: for one, by direct exposure to the work of Comité d'Entraide Internationale - CEI (International Aid Committee) of the Evangelical Protestant Church in Morocco (Eglise Evangélique au Maroc, EEAM). Here, CWWM participants helped with food distribution and interviewed migrants. Second, as the 'witnessing' in the title implies, the sharing of experiences by migrants and refugees forms a central part of the CWWM. Among those telling their stories were Erwiana Sulistyaningsih, an Indonesian migrant domestic worker who suffered enormous abuse while being employed in Hong Kong. Grass-roots migrant organizations in Hong Kong launched a major 
campaign to support her and she - successfully - brought her abusive employer to court. Another witness was Celia Veloso, the mother of Mary Jane Veloso, a Filipino migrant worker who faces a death sentence in Indonesia for (unknowingly, as she insists) being used for drug trafficking.

The CWWM also addressed issues that were otherwise rarely addressed in Marrakesh - among them the Compact for Refugees and the situation of the internally displaced: 'What to do with internally displaced peoples and the Global Compact for Migration that is Silent about them?' was the title of a presentation by Cecilia Jimenez-Damary, UN Special Rapporteur on the Human Rights of Internally Displaced Peoples. Lina Cahuasquí from MIREDES (Migrants, Refugees and the Displaced) reported from the Migrant Caravan' at the US-Mexican border: 'It is not a migrant caravan, it is an exodus. The causes are poverty, generalized corruption, lack of employment, violence and impunity. Here, migration is an act of resistance - it should become activism that brings together social forces'.

The CWWM thus linked to the fourth General Assembly of the International Migrants Alliance (IMA) in November 2018 in Mexico City's Colonia Tabacalera, held under the theme 'March onwards a world without forced migration: Migrants, refugees and peoples of the world unite and fight capitalist exploitation, plunder and war! Forge the strongest solidarity with the host people in effectively fighting imperialism!'. Here, participants had not only deliberated on the GCM and related issues but also assisted members of the caravan.

The IMA meeting coincided with the World Social Forum on Migration (WSFM), a major, potentially counterhegemonic, 'invented space', discussed in the book's Chapter 2. Under the slogan: migrate, resist, build and transform, over 1000 migrants, human rights defenders, academics and activists from 70 countries gathered 2-5 November 2018 for the eighth global summit of the WSFM in Mexico City, among them several organizations also participating in the 'migration week' in Marrakech, including, for example, La Via Campesina, TMP-E and MDDC. Thematic actions for discussion at the WSFM included, among other, the realities of new walls, their structuralinstitutional conditionalities and their relation to current political hegemonies. They included migration and climate change, gender and migration, politics of resistance driven by social movements and collective action and forced migration in the context of the systemic crisis of capitalism.

Compared to civil society participation in the GFMD, the UNHLD and consultations pertaining to the Global Compact, the WSFM constitutes a genuinely autonomous 'invented space'. It aims to promote, in theory and practice, and with its own calendar and geography, a counterhegemonic block aimed at addressing the root causes of the currently dominant forms of migration. Compared to the limitations of the 'invited' spaces in which civil society has been participating - including forums for deliberations on the Global Compact - the WSFM represents a potentially more powerful forum for addressing root causes and consequences of as well as alternatives to currently dominant forms of, often, forced migration and the precarious conditions of labour and livelihoods related to this.

Two intersecting activities were organized at the 2018 WSFM in Mexico City, targeted at ensuing in globally extended campaigns: (a) Uniting for an alternative global compact for and driven by migrants and refugees and (b) Creating a global network of sanctuary spaces and cities. As a result of these intersecting CSO activities it was agreed to promote the formation of a Global Compact of Sanctuary Cities (GCSC), to be formally launched in Madrid by mid-April 2019.

This initiative is aimed at transcending a short-term resistance strategy against the current xenophobic wave. Its main purpose is to foster a new model of interconnected intercultural cities and local solidarity spaces that allows an inclusive citizenship regardless of migratory status: a strategy for making places where 'everybody can belong', turning thus 'the "crisis" of undocumented migration 
into a pragmatic reality of daily urban life and coexistence' (UNESCO-LUCS 2018). It will build on experience harvested in the context of a number of already existing initiatives concerning 'right to the city' (Lefebvre 1968) in terms of 'sanctuary cities' (Bauder 2017), politics of 'urban citizenship' (Smith et al. 2012), 'solidary cities', ${ }^{17}$ 'welcoming' or 'sustainable cities' (Taran et al. 2016) as political and socio-judicial models. It has, from a similar perspective (Bauder et al. 2018), been argued that the idea of supportive cities might indeed challenge the 'sovereign right of States' to determine their national migration policy: as noticed, a keystone of the GCM. Yet, it can hardly be a universal formula. According to an illuminating transatlantic enquiry (de Graauw et al. 2016) it is a road to empowerment which has proved to be most substantial where several key elements occur synergistically: left leaning local governments, immigrants constituting a large part of the city electorate as well as a part of decision-making structures and strong community-based organizations with capacity to represent migrants' interests in local politics. It could, on these premises, be one road from Marrakech towards underpinning rights and livelihoods of migrants through a substantial trans-local and transnational citizenship, despite increasingly inhospitable national social contexts and politics.

\section{Acknowledgement}

We wish to express our gratitude to Jille Belisario, Brid Brennan and Patrick Taran who, in the middle of the festive season, have taken time to review and comment on the manuscript and to offer valuable propositions for its improvement.

\section{Notes}

1. The final text of the GCM is available at: https://refugeesmigrants.un.org/migration-compact.

2. Foranoverviewsee:https://gfmd2010.wordpress.com/2018/11/23/updates-on-marrakesh-formigrationweek-events-themes-locations-gfmd/.

3. https://refugeesmigrants.un.org/declaration.

4. Text of the 1990 UN Migrant Workers Convention available at: www.ohchr.org/en/professionalinterest/pages/cmw.aspx.

5. A discourse of 'human rights' was launched by the UNHLD on Migration and Development and later adopted, or rather appropriated by the GFMD process on migration and development. It was restated on the occasion of the 2013 UNHLD in New York, but again subordinated to the business-friendly GFMD agenda for migration management (Chapter 3). Parallel with this, as argued in the book's Chapter 6, the ILO and the international trade unions were from this point progressively marginalized in the UNHLD and GFMD processes. See further Chapter 3, Schierup, Ålund and Likić-Brborić (2015) and Global Unions (2013).

6. Available at: www.icvanetwork.org/resources/joint-civil-society-message-global-compact-migration.

7. Discussed in Chapters 2 and 3.

8. See, for example: https://gfmd2010.wordpress.com/2017/10/31/a-global-compact-from-below-civilsociety-issues-ten-acts-for-a-compact-on-human-mobility-and-migration/.

9. See the Joint Civil Society Statement, available at: http://gcmigration.org/2018/07/joint-civil-societystatement-at-the-conclusion-of-negotiations-on-the-global-compact-for-safe-orderly-and-regularmigration/.

10. Available at: http://transnationalmigrantplatform.net/tmp-e-recommendations-to-global-compact-onmigrants/.

11. https://ftdes.net/18-decembre-1990-18-decembre-2018-appel-pour-legalite-des-droits-et-la-justicesociale/.

12. www.tribunalonfracking.org/what-is-the-permanent-peoples-tribunal/. 
13. http://transnationalmigrantplatform.net/migrantppt/.

14. A term introduced by Mbembe (2003).

15. Stopthe WaronMigration!DeclarationofFMASandMagrebSocialForum.Availableat:https://transnational migrantplatform.net/1214-2/.

16. Available at: https://viacampesina.org/en/wp-content/uploads/sites/2/2018/12/EN-AGREEMENTMARRAKECH.pdf.

17. See: https://solidaritycities.eu/about.

\section{References}

Bauder, H. (2017). Sanctuary Cities: Policies and Practices in International Perspective. International Migration, 55, 174-87.

Bauder, H. and L. B. Landau. (2018). Why Cities Hold the Key to Safe, Orderly Migration. WorldEconomic Forum. Available at: www.weforum.org/agenda/2018/10/why-cities-hold-the-key-to-safe-orderly-migration/.

de Graauw, E. and F. Vermeulen. (2016). Cities and the Politics of Immigrant Integration: A Comparison of Berlin, Amsterdam, New York City, and San Francisco. Journal of Ethnic and Migration Studies, 42 (6), 989-1012.

Global Unions. (2013). Open Letter to United Nations Secretary General Ban Ki-Moon Concerning Trade Union and Civil Society Inclusion at the High-Level Dialogue on Migration and Development New York, October 3-4, 2013, MIGLINK, Public Services International. Available at: http://world-psi.org/en/ support-our-action-sign-letter.

ICVA. (2018). Joint Civil Society Message on the Global Compact for Migration, ICVA - International Council of Voluntary Agencies. Available at: www.icvanetwork.org/resources/joint-civil-society-message-globalcompact-migration.

Lefebvre, H. (1968). Le droit à la ville. Paris: Anthopos.

Mbembe, A. (2003). Necropolitics. Public Culture, 15 (1), 11-40.

MDDC. (2018). '18 décembre 1990 - 18 décembre 2018 Appel pour l'égalité des droits \& la justice sociale' Secrétariat de la plateforme Euro-Marocaine MDDC.

PICUM. (2018). Statement Civil Society Days Marrakech: PICUM and its Partners Highlight Realities of Undocumented Migrants, PICUM News. Available at: https://picum.org/statement-civil-society-daysmarrakesh-picum-and-its-partners-highlight-realities-of-undocumented-migrants/.

Rother, S. (2018). The Global Forum on Migration and Development (GFMD) as a Venue of State Socialization: A Stepping Stone for Multi-Level Migration Governance? Journal of Ethnic and Migration Studies, 44. doi: 10.1080/1369183X.2018.1441605.

RSMMS. (2018). 'Position du Réseau Syndical Migration Méditerranéennes-Subsahariennes (RSMMS) sur le "Pacte mondial pour des migration sûres, ordonnées et régulières"' (Ed, RSMMS) Les organisations syndicalles membres du RSMMS.

Schierup, C.-U., A. Ålund and B. Likić-Brborić. (2015). Migration, Precarization and the Democratic Deficit in Global Governance. International Migration, 53 (3), 50-63.

Smith, M. P. and M. McQuarrie eds. (2012). Remaking Urban Citizenship. Organizations, Institutions and the Right to the City. New Brunswick (NJ): Transaction Publishers.

Taran, P. (2018). 'Open Letter on the Global Compact for Safe, Orderly and Regulated Migration'.

Taran, P., G. d. L. Neves and O. Kadysheva. (2016). Cities Welcoming Refugees and Migrants: Enhancing Effective Urban Governance in an Age of Migration. No., Paris: UNESCO.

UCLG - Committee on Social Inclusion, P. D. a. H. R. (2018). 'Marrakech Mayors Declaration. Cities Working Together for Migrants and Refugees' UCLG.

UNESCO-LUCS. (2018). Urban Citizenship. Making Places where Everybody Can Belong, Botkyrka, Stockholm, MKC.

United Nations. (2018). Global Compact for Safe, Orderly and Regular Migration. Available at: https:// refugeesmigrants.un.org/migration-compact. 


\section{Index}

Note: Page numbers followed by "n" denote endnotes.

accumulation $6,8,20,127$

activism 5, 33, 43, 79-81, 88-90, 96, 104, 161, 162

Addis Ababa Action Agenda 43

Addressing Irregular Migration through Coherent

Migration and Development Strategies 55

The African Poor (1987) 142

Agricultural Structural Adjustment Program

(ASAP) 145

Agtas, Ö. B. 110

Ålund, A. 9-10, 53, 96, 129

Amin, S. 18

Amler, B. 110

Annan, K. 38, 53

Arbour, Louise 25

articulation $8,9,11,35,83,120,132,135$

Asia-Pacific Mission for Migrants (APMM) 133

asymmetric global governance 9, 32, 34

Ayers, J. 128

Balkan immigrants 103

Bartelson, J. 66

Bates, Robert 143

Bauder, H. 6

Belgium 54

Berne Initiative (2001) 38

Betts, A. 5, 10, 25, 36, 95

Bloom, T. 57

Bretton Woods international financial institutions

(IFIs) 43

Bretton Woods paradigm 35

Brock, K. 85

Buckley, K. M. 9

Burkina Faso 144

Burrow, S. 41

business mechanism 41

Cairo 38

Canada's Temporary Foreign Worker Program 86-7

capitalism 12, 18, 19, 20, 22, 28, 34, 37, 49, 69, 125,

$126,152,162$ capitalist globalization 127-8

Caritas Sweden 87

Castells, M. 51, 66

Castles, S. 6, 49, 59

catastrophe 20

ÇELİK-İS Union 115

Children's Film and Art Association 102

China 6, 7, 19

Churches Witnessing With Migrants (CWWM) $125,126,130,133-5,156,161,162$

Circular Migration Programme 54

Cissokho, Mamadou 148

citizenship 8, 110

civic activism 79, 88-90

civil society $3-8,22,127$; actors 43 ; contestative 160-1; European 141, 146; GFMD 42, 53, 57-60, 66-7, 72, 97, 124, 135; GFMD-CSD 70, 75 ; movement of 84 ; in neoliberal governance 8-11; networks 4; and NGOs 130; participation of 21-5, 27-8; representation 10; screening, embedding and NGOizing 87-8; Turkish 101-4

Civil Society Days (CSDs) 4, 7, 22, 33, 39-40, 57, 67, 81, 97, 98, 124; GFMD and 95-7; irregular migrants 57-9; migrant/diaspora entrepreneurship 59-60; participation 24-5; and Turkish civil society 101-3; Turkish GFMD 10; see also Global Forum on Migration and Development's Civil Society Days (GFMD-CSD)

Civil Society Mechanism 150, 152

civil society organizations (CSOs) 4, 5, 10, 12, 24, $26,33,34,39,40,42-4,45 \mathrm{n} 16,54,60,66,75$, 79-80, 79-85, 95-7, 102, 103, 110, 144, 145, 147, $152,156,158-60,162$

Civil Society 'Stockholm Agenda' 43, 58-9, 61n20

class-orientated grassroots organizations 23

CNCR see National Committee for Rural Peoples' Dialogue (CNCR)

Cold War 36, 37

colonialism 142, 151 
Committee on World Food Security (CFS) 5, 12, 150,152

Common Space (CS) 4, 10, 40, 53, 54, 67, 71, 82,124

Common Space Day 67

compulsive displacement 19-20

CONCORD 146, 147

configuration and expansion of global networks of monopoly capital 18

contemporary migration $7,16,18,25,36$

Cooperation Strategies among States to Address Irregular Migration: Shared Responsibility to Promote Human Development 55

Cornwall, A. 85

counterhegemonic 132; agency 28; ambitions 90 ; civil society engagement 5 ; discourse 9 , 80,130 ; formation 83,84 ; network 89 ; potential 23, 24; practices 23,85 ; resistance $11,125,126$; social movement 26,85 ; solidarity $160-3$

counter-movement 4

Cox, Robert W. 126-9, 135

credit system 142

Crépeau, F. 41

criminal activity 20; see also human trafficking and smuggling

CSDs see Civil Society Days (CSDs)

CSD Steering Committee 42

$\mathrm{CSO} / \mathrm{ICSO}$ 84-5

CSOs see civil society organizations (CSOs)

Cubas, M. A. 49

Cuttitta, P. 68

CWWM See Churches Witnessing With Migrants (CWWM)

Danish unions 109, 110

Decent Work Agenda (DWA) 4, 37

de facto temporary protection 112

democratic space 89

denizenship 8

depoliticise migration 22

depoliticized approach 9

deportations 21

de-regulation, forced labour 7

developmental approach 41

Disaster and Emergency Management Authority 112

dispossession 10, 12, 21, 50, 59, 90

domestic and care work 52

domestic work 55-6

double movement 4

Doyle Report 38

DİSK 111, 113, 114

ecological crisis 19

economic migrants $16,21,37,41,100$, 104,141
Economic Community of West African States (ECOWAS) 150, 151, 152

Economic Partnership Agreements (EPAs) 152

EIP see External Investment Plan (EIP)

Eldring, L. 110

embedding $87-8$

employment $6,7,11,18,19,33,52,100,128$; formal 51, 115, 117; informal 7, 49-61, 111; registered $112,114,116,120$

Engaging Diaspora as Entrepreneurs, Social Investors and Policy Advocates 59

equivalence, networks of $5,9,10,23,27,83,89,90$, 91

era of generalized monopolies 18

Erdogdu, S. 11

ethnic entrepreneurship 52

ethnocentricity 83

EU Commission 39, 99

Europe 12, 16, 21, 33, 39, 70, 73, 82, 109, 110, 118, $141,144,146,149,151,159$

European civil society 141, 146

European Economic Community 143

European perception of West African migration 146-7

European Union (EU) 7, 8, 11, 39, 52, 87, 94-5, 97, 99, 101, 104, 105n6, 110, 113, $115,118,134,135,141,146,147,151,152$, $157,158,161$

Evans, T. 128

exclusion 21

expulsion 20

External Investment Plan (EIP) 146-7

extractivism and land grabbing 18-19

facilitative multilateralism 10

A Fair Globalisation 35

Fair Migration 43

Fair Recruitment Practices Project 43

Fédération des ONG Sénégalaises (FONGS) 144

Feixa, C. 81

Fernandez, Irene 131, 133

2014-2015 Final Concept Note 41

First World War 109

Flecker, K. 86

flexibilisation 7

FONGS 145, 149, 150

forced displacement/migration 8

forced labour 7-8

forced migration 18-21, 50

formal employment 51, 115, 117

formal/institutional participation 24

Forums' Government Days 54

Fourth Industrial Revolution 44

France 98, 109, 143

Franke, Milena 74

Freeman, R. 19

Fulias-Sourroulla, M. 53 
Gamlen, A. 36

GATT/WTO-driven international trade regime 35

Gaventa, J. 10, 85, 88, 89, 99

Geiger, M. 37, 39, 95

Geneva Migration Group 38

German unions 110

GFMD Civil Society Coordinating Office 42

GFMD Civil Society Days 53, 57-60, 124, 135, 158

GFMD government days approach 53-4; domestic work 55-6; informal sector 54-5; migrant/ diaspora entrepreneurship and informal sector enterprises $56-7$

GFMD summit 5, 7, 10, 41, 132, 133

GFMD/UNHLD process 81

Gill, S. R. 126, 127

Global Care Workers at the Interface of Migration and Development 56

global civil society $9,11,34,43,66-9,75,81,84,87$, $127,158,161$

Global Coalition for Migration (GCM) 26, 42, 85,124

Global Commission on International Migration (GCIM) 38

Global Compact for Migration (GCM) 4, 5, 9, 25-7, $41,42,44,70-2,75,85-6,135,156-63,157$

Global Forum on Migration and Development (GFMD) 3-5, 7, 9-11, 29n4, 33, 39-40, 50, 53, 65-6, 86, 124, 129-35, 156-8, 160, 162; chair 99; CSD process $33-4,39-43,45 n 9,65-6,69-75$, 87, 95-7; global migration governance 66-8; human rights 57-9; informal employment 55-6; informal sector 54-5, 56-7; intergovernmental meetings 81,82 ; meetings $4,33,39-41,53,55$, 56, 81, 130; Mexico 54-6; migrant civil society in 21-5; migrant/diaspora entrepreneurship 56-7, 59-60; objectives of 17-18; Stockholm 90; Sweden 60; Turkey 94-104, 105n2; UN High Level Dialogue 80-1; UN-HLD and 21-8; and UN's systems 86

Global Forum on Migration and Development's Civil Society Days (GFMD-CSD) 9, 33-4, 39-42, 65-7, 69-75

Global Forum on Remittances, Investment and Development (GFRID) 129

global governance 3-5, 7, 9-12, 17, 18, 23-4, $27-8,32-5,37,39,41,42,44,57,65,66,70-2$, $74,75,80,81,84,87,89,96,97,99,130,134$, 156,161

globalization 4, 7-9, 12, 19, 22, 26, 32, 34, 35, 37, $43,44,49-51,54,55,61,65,67,79,81,82,90$, $128,131,134,136,141,152$

global labour arbitrage 18, 19

global migrant precariat 7

global migration discourses 11,161

global migration governance $8,17,18,25,33,34$, 36-42, 44, 66-8, 81, 95, 96, 99, 104, 105n1, 125, $128-30$
Global Migration Group (GMG) 3, 17, 38, 39

global migration policy 38

Global Migration Policy Associates (GMPA) 160

global political economy 34-5

global population 39

global production networks (GPN) 34

global south $6,7,10,18-20,73,74,90,127,161$

global trade 32

Global Unions (2015) 87

global value chains (GVC) 34

GMG see Global Migration Group (GMG)

Gois, William 85, 86, 88

Gómez Camacho, Juan José 25

good migrant 22

Gorodzeisky, A. 111

government: of Brazil 158; forum 7, 101; global civil society and $66-7$; policy $35,52,128$; Swiss 38; Turkish 104

Government Days 7, 50, 53, 54, 56, 58-61, 67

government-organized non-governmental organization (GONGO) 102

Gramsci, A. 4, 23, 83, 127-8, 130, 135

Gramsci, Hegemony and International Relations (Cox) 126

Great Doubling 19

Great Transformation 82

Greece 101

Grillo, R. D. 95, 98

growing negative regulatory capacities 7

guest-worker systems 8

Hague Process on Refugees and Migration (THP) 40, 45n 11

HAK-İS 114,115

Hall, S. 79, 83

Hardy, J. 110

Harvey, D. 43

hegemony of progressive neoliberalism 44

Henrikson, O. 40

Hernández Mares, K. V. 132

High-Level Dialogue (HLD) 40, 53, 58, 85-7, 86

High Level Dialogue on International Migration and Development (UN-HLD) 3, 5, 10, 17, 21-8, 33, 39, 96, 126, 129, 133

High-Level Political Forum on Sustainable Development (HLPF) 9, 43

historic bloc 126-7, 129, 134, 135

Hong Kong 130

Hultin, G. 40

human mobility 17,23

human rights $4,5,10,17,20,22-6,34,36,37$, $40-4,50,53-60,68,70,71,80,82,84,88-90,97$, $100-2,104,118,125,128,129,131-5,141,146$, $151,157-9,161,162,163 \mathrm{n} 5$

human rights of migrants $40,41,55,100,131,156$, 157,161

human trafficking and smuggling 20-1 
hyper-exploitation 7

hyper-precarity 53

ICPD PoA progressive development approach 38

Identitarian Movement (Identitäre Bewegung) 157

illegality discourse 8

Illife, John 142

ILO Convention 56

Image of Africa project 145

IMF 39, 43

IMN 67

imperialism 131

independent human rights 23

India 19

industrial relations 35,110

informal economy 50-1

informal employment 7, 49-61, 50-3, 55-6, 111

informalisation of labor 6

informal labour markets and irregular

migration 50-3

informal sector 50-1, 51-5

informal sector enterprises 50, 52, 54, 56-7, 60

insecure jobs 51-2

inside-outside strategy 5, 90-1

institutional appropriation 90

intergovernmental organization 37

International Agenda for Migration Management (IAMM) 38

International Catholic Migration Commission (ICMC) 10, 24-5, 29n4, 40, 87, 97

International Civil Society Steering Committee 97

International Committee (IC) 27

International Confederation of Free Trade Unions 109

1994 International Conference on Population and Development (ICPD) 38

international framework agreements (IFAs) 37

International Fund for Agricultural Development (IFAD) 129

internationalism 110

international labour migration 52

International Labour Organisation (ILO) 4, 19, 33, 35-8, 42-4, 44n1, 50, 53, 54, 56, 87, 88, 105n2, $126,128,159,160$

International League of People's Struggle (ILPS) 131

International Migrants Alliance (IAMR) 75, 125, $126,130-5$

International Migrants Alliance (IMA) 11, 125-8, $130-6,162$

international migration 4-6, 10, 17, 21, 25, $28,32,36,38,39,41,53,59,65,66,95,96$, 103,158

International Migration and Development 38

international migration narratives (IMN) 65, 66, 67; concealed contestations at GFMD 72-4; (re) politicization 74-5; (de)politicization and the production 68-9; space for 69-72

International Migration Peter Sutherland 100

international migration regime 25, 28, 33

International Organisation for Migration (IOM) 17, $25,36-9,42,43,53,95,128$

international organizations (IOs) 9, 66

International Secretariat of National Trade

Unions 109

International Steering Committee 97

International Trade Union Confederation (ITUC) 41

International Tribunal of Conscience (ITC) 132

International Working Group (IWG) 82

inter-regional fora (IRF) 38

interrelated migration issues 36

invented and invited spaces 9-10, 12

invented spaces 156

invited spaces $80,84-8$

irregular migrants 53-4; domestic work 55-6;

from human rights 57-9; informal sector 54-5;

migrant/diaspora entrepreneurship and informal sector enterprises $56-7$

irregular migration 5-7, 11, 22, 33, 35, 38, 49-55, $57-61,68,100,110,111,129,141,146,149$; informal labour markets and 50-3

Istanbul 5, 10, 11, 34, 41, 56, 60, 72, 81, 87-90, 94, 97, 100, 103, 115, 118

Izmir Balkan Migrants Culture and Solidarity Association 102

Jinnah, Zaheera 9

Juris, J. 81

Kaldor, M. 84

Kalm, S. 38-9

Kenya 50

Kim, C. 49

Koser, K. 40

Kunz, R. 36, 37

labour exploitation 20

labour, forced 7-8

labour market 20-2, 32, 34-8, 41, 50-2, 54-60, 104, $110-20,128,130$

labour mobility 37, 40

Labour Mobility and Development 56

labour rights 37

Laclau, E. 83

land grabbing 18-19

Latin America 29n10

Lauber, Jürg 25

Law, D. 127

Law on Foreigners and International Protection 94 leadership 17, 23, 24, 29n4, 74, 125

legitimation 66 
Lestari, Eni 131, 136

Likic-Brboric, B. 8-9, 53, 128

lower-skilled workers 125

Maas, W. 40

McKeon, N. 11-12

mainstream organizations 23

Majone, G. 7

managed migration 7,8

manufacturing activities 52

Marino, S. 111

Marsh, K. 36

Martin, S. 37, 38

Medina, Jose Jacques 133

Mediterranean Crisis 100

Mexican PGA 82

Mexico 10, 22, 24, 25, 27, 40, 54-6, 58, 81, 82, 87, $102,125,132,134,162$

micro, small and medium enterprises (MSME) 147

MIGLINK project 95, 102, 105n 1

Migrant Forum for Asia (MFA) 33, 43

migrants: categories of 37 ; civil society $21-5$; diaspora entrepreneurship 56-7, 59-60; domestic work 55-6; in informal sector 54-5; labour 50-4, 58, 109, 110, 112, 113, 119, 125, 129,161 ; to restrictive policies 109-11; rights networks 11, 161; in Turkey 101-2; women $45 \mathrm{n} 16,51-3,55,56,60,71,74,83,111,125,144$, 150, 151, 161; workers and refugees 37, 44, 126

Migrant Solidarity Network 101, 102

Migrants Rights International (MRI) 33

migration 6; articulation of 35; civil society participation 23-4; compulsive displacement 19-20; crisis 101-3, 140-1, 144, 146-7; depoliticized approach 9; and development 21-5, 34, 39-42, 53; evolution of 142-4; expulsion process 20; forced 18-21; global coalition on 25-6; governance 42-4; irregular 5-7, 11, 22, 33 , 35, 38, 49-55, 57-61, 68, 100, 110, 111, 129, 141, 146, 149; management 8, 22, 24, 38-9, 43; policies $5,21,22,24,35,37,38,52,55,57,60,69$, $81,87,88,100,111,113,119,133,134,158,163$

Migration and Development Civil Society (MADE) Network 4, 29n4, 42, 70, 87, 97

Migration and Socio-Economic Development 40

Migration, Civil Society and Global Governance 4

Migration Partnership Framework 146

Migration Policy Institute 22, 129

Mingione, E. 8

Miraftab, F. 10, 85, 88, 99

mobility $8,16,17,20,21,23,26,36,37,40-4,50$,

$55,56,58,82,100,109,141,142,144,146,152$

monopolies 18

Mouffe, C. 83

movement politics 9-10

moving map of neoliberalization 35
Moyn, S. 90

Multilateral Framework on Labour Migration (2006) 53

multilateralism 36

Multisectoral Global Funds (MGF) 42

Munck, R. 128

National Committee for Rural Peoples' Dialogue (CNCR) 145, 147, 149, 150

National Council of Churches in the Philippines (NCCP) 133

national labour market regulations 35

national laws and regulations 49

Neergaard, A. 128

neo-Gramscian approach 23, 80, 126

neoliberal globalization 7, 8, 22, 34, 49, 50, 51

neoliberal governance, civil society in $8-11$

neoliberalism 7, 44, 54, 69, 80

neoliberalization 34-5

neoliberal migration regime 38-9

neoliberal transformation 6

neoliberal transnational historic bloc 25

neo-Marxist regulation theory 6

network of equivalence 91

Network of West African Peasant and Agricultural

Producers' Organizations: (ROPPA) 145-7, 149, 150,152

networks of equivalence $5,9-10,23,80,83-4$

'new' global movement 81-3

the new migration and development optimism 36 'new-new' globalized social movements

(NNSM) 81

New York Declaration 4, 17, 41, 70, 157-9

New York HLD (NY HLD) 85-6

New York PGA 86

NGOizing civil society $87-8$

non-government organizations (NGOs) 10, 17, 23,

$26,35,37,39,42,44,66,69,84,85,90,97,101$,

$102,104,141,144,146,152,156,158$

non-representative representation 103-4

North America 39, 110

El Nour, Ashraf 129

Official Development Assistance (ODA) 146

Onuki, H. 126, 127

open door politics 11

Operationalising Protection and Human

Development in International Migration 59

outsiders by choice 130

Özkul, D. 49

pacification through appropriation $85-7$

PANiDMR 158-9

paradoxes of sustainability 8,434

Pécoud, A. 9, 37, 39, 66-9, 72, 73, 75, 95

pendular process 24 
Penninx, R. 110, 111

People's Global Action on Migration, Development and Human Rights (PGA) 4, 10, 17-18, 24-6, 28, $33,40,54,67,72,74,75,80-2,84-91,97,102$, $124,125,133,135,156-8,160,161$

Pereira, I. 81

Pérez-Bustillo, C. 132

permanent temporary migration 125

PGA-CSD connection 24

PGA/WSFM 42, 44

Philippines 54, 56, 131-3

Phillips, N. 35

Piore, M. J. 6, 51, 125

Platform for International Cooperation on Undocumented Migrants (PICUM) 33, 158-9

Polanyi, K. 4

policy ambivalence 151-2

policy discourses 68

policy space 89

political rationality 39

political space $88-90$

(de)politicization 68-9

(re)politicization 74-5

Portes, A. 51

positive redistributive state 7

post-national workfare state 8

Post Washington Consensus (PWC) 33, 35, 39

poverty $6,19,32,35,37,44,59,84,89,111,142$, $146,149,151,162$

precarious workers 6

Precarity Movement 101

privatizations of public services 35

problem of representation 10, 11, 95, 98-9

Problem of Representation 989

Programme of Action (PoA) 38

pro-migrant civil society $101-2$

Protecting Migrant Domestic Workers - Enhancing their Development Potential 56

Purcell, M. 9, 80, 83

refugees and asylum seekers 37

regional consultations processes (RCPs) 38

Regulation on Work Permit of Refugees under

Temporary Protection 112

regulatory state 7

Re-imagining Labour Mobility 58

reiterative failure 24

Re-politicising International Migration Narrative 9 repoliticization $66-9,75$

representation of problems 95, 98-9

re-regulation 7

restrictive policies $109-11$

restructuring process $18-19,28$

return migration 21

Richards, A. 111

rights-based approach 5, 33, 34, 37, 39, 45n16, 53, 124,129
Roosblad, J. 110, 111

ROPPA see Network of West African Peasant and Agricultural Producers' Organizations (ROPPA)

Rother, S. 11, 42, 55, 57, 82

Roundtable (RT) agendas 39

rural communities 147-50

Safe Migration: Root Causes, Route Choices and Alternatives to Forced and Dangerous Migration 59

São Paulo 27, 82

Sassen, S. 104

Sauviat, L. 110

Schierup, C.-U. 9-10, 53, 57, 96, 128, 129

Schulten, T. 110

Schwab, K. 42

screening process $87-8$

Second World War 8, 100

sector-specific development policies 41

secure jobs 51-2

securitization $8,42,55,161$

Senegalese FONGS 145

Senses, N. 10

settlement 8

Shaping Migration and Development Goals: Global Movement, Change on the Ground 58-9

Sison, Jose Maria 131

Sivanandan, A. 6

Slavnic, Z. 6

small-and medium-sized enterprises (SMEs) 56, 60

social exclusion 20

social inequalities $19,22,50$

Social Integration of Refugees Through Vocational Education 115

socialism 6,7

social justice movements 53

social movements 28, 29n10, 83-4

social transformation process 10, 27, 126, 145

Southern Europe 111

Soykan, C. 10

Standing, G. 51, 53

state-led consultative process 38

Steering Group (SG) 39

Stockholm 10, 41, 81, 87, 89, 90

Stockholm Agenda 43, 58-9, 61n20

straddling policy $88-90$

Strengthening Partnerships: Human Mobility for

Sustainable Development 100

sub-regional process 38

Sub-Saharan Africa (SSA) 141, 143

Subsaharan Migration Trade Union Network

(RSMMS) 159

sustainability $8,33,42-4$

2030 Sustainable Development Agenda 42-4

sustainable development goals (SDGs) 9, 34, 40, 42-4, 45n16, 70, 71, 97, 100, 151

Sutherland, P. 39 
2008 Swedish labour migration law 40-1 Swedish Trade Union Confederation (LO) 87

Swiss chair 55, 56

Switzerland 100

Syria 10, 33, 94-5, 112, 113, 117

Syrian labour 116, 117

Syrian refugees $11,59,95,100,101,103,104,108$ 9, 112-20; irregular labour migration 111-12; restrictive policies 109-11; trade unions 111-12; in Turkey 112-19

temporary/guest workers' programmes 22 temporary migration 8

Terwilliger, Mark 134

3R (Recruitment-Remittances-Return) approach 43

Toksöz, Gülay 7

top-down management approach 128

Towards a Global Social Contract on Migration and Development 41

trade union responses $11,108,110,113-19$

transnational corporations (TNCs) 33

Transnational Migrant Platform (TMP) 33

Transnational Migrant Platform-Europe (TMP-E) 159

transnational migration 6

transnational mode 36

transnational socialization 126

transversal dialogues 83-4

transversal hegemony 9

transverse optimum 9

trasformismo 127, 130, 135

Trimikliniotis, N. 53

triple bottom line 43

triple-win benefits 38,43

Troika governments 39,40

Trump's immigration policy 136

TÜRK-İS 111, 113, 114

Turkey 5, 10, 11, 24, 59, 73, 87, 105n1, 105n6, 108, 109, 111-20, 120n3, 120n5; chair 99-101; civil society 101-3; GFMD and CSDs 95-7; irregular labour migration 111-12; legislation 101; military intervention in 111; non-representative representation 103-4; objectives 100; problem of representation 98-9; pro-migrant civil society 101-2; social transformation 10-11; Syrian refugees in 112-19; trade unions 111-12

Turkish Confederation of Employer Associations 102

umbrella organization 25-6, 29n4, 130 UN 2030 Agenda for Sustainable Development 5 UN Committee on World Food Security (CFS) 150 1990 UN Convention on the Rights of All Migrant Workers and Their Families 17 UN 2030 Development Agenda 9, 34 unemployment $21,35,59,110,114,117$ uneven development 19

UN Food and Agriculture Organization (FAO) 145

UN General Assembly 4, 17, 25, 129

UN Global Compact 24

UN High Commissioner for Refugees (UNHCR) 36,37

UN High Level Dialogue (UNHLD) 3, 5, 10, 17, $21-8,33,39,80-1,85,87,88,90,96,126,129$, $133,156,158,162$

UNHLD-GFMD process 5

UN Human Rights Council 5, 152

UN-initiated GFMD process 4

United Nations (UN) 3, 95; conventions of 159; and international business community 24 ; mandate 95; and World Bank 129

United Nations High Commissioner for Refugees (UNHCR) 20, 70

UN Migration Agency 42

UN paradigm 35

UN Post-2015 Development Agenda 34

UN Refugee Agency (UNHCR) 53

UN Secretary-General 17, 35

UN Summit on Migrants and Refugees 131

UN system and civil society $23-4,34$

upsurge of monopoly finance capital 18

US anti-communism 36-7

Van Hear, N. 59

Vanyoro, Kudakwashe P. 9

variegated neoliberalization 34

Veltmeyer, H. 85

violence 20

war in Syria (2011) 10

war of movement 82-3, 127

war of position 82, 85, 126, 127, 131, 135, 136

Wee, Kellynn 9

WEF Global Agenda Council on Migration 40

West Africa 11, 12, 141-52, 159; drivers in 142-4; European perception 146-7; rural communities 147-50

West African peasant movement 144-6

White paper for the United Nations General Assembly High Level Dialogue on International

Migration and Development 201340

win-win-win policies 8,91

Wise, Raúl Delgado 8, 12

women migrants $45 \mathrm{n} 16,51-3,55,56,60,71,74,83$, $111,125,144,150,151,161$

Woolfson, C. 53

World Bank (WB) 21, 33, 43

World Commission on the Social Dimension of Globalisation (WCSDG) 35

World Economic Forum (WEF) 40, 44

World Social Forum (WSF) 4, 12, 82

World Social Forum on Migrations (WSFM) 4, 12, $17,18,26-8,33,82,86,132$ 
World Trade Organization (WTO) 33, 35, 43, 57 World Trade Organization/General Agreement in Trade in Services (WTO/GATS) 37

WTO/GATS mode 39

WTO/WB/IMF 43

xenophobic populism 7, 146

Youth Council 150

Yuval-Davis, N. 83-4

Zapatista movement 28 